\title{
A fluid inclusion study of acidity in bedded halite of the Larne Halite Member, Triassic Mercia Mudstone Group from the Carnduff 2 Core, County Antrim, Northern Ireland
}

Lynnette Ann Eichenlaub

Follow this and additional works at: https://researchrepository.wvu.edu/etd

\section{Recommended Citation}

Eichenlaub, Lynnette Ann, "A fluid inclusion study of acidity in bedded halite of the Larne Halite Member, Triassic Mercia Mudstone Group from the Carnduff 2 Core, County Antrim, Northern Ireland" (2016). Graduate Theses, Dissertations, and Problem Reports. 5532.

https://researchrepository.wvu.edu/etd/5532

This Thesis is protected by copyright and/or related rights. It has been brought to you by the The Research Repository @ WVU with permission from the rights-holder(s). You are free to use this Thesis in any way that is permitted by the copyright and related rights legislation that applies to your use. For other uses you must obtain permission from the rights-holder(s) directly, unless additional rights are indicated by a Creative Commons license in the record and/ or on the work itself. This Thesis has been accepted for inclusion in WVU Graduate Theses, Dissertations, and Problem Reports collection by an authorized administrator of The Research Repository @ WVU. For more information, please contact researchrepository@mail.wvu.edu. 


\title{
A fluid inclusion study of acidity in bedded halite of the Larne Halite Member, Triassic Mercia Mudstone Group from the Carnduff 2 Core, County Antrim, Northern Ireland
}

\author{
Lynnette Ann Eichenlaub \\ Thesis submitted \\ to the Eberly College of Arts and Sciences \\ at West Virginia University \\ in partial fulfillment of the requirements for the degree of \\ Master of Science in \\ Geology
}

\author{
Kathleen Benison, Ph.D., Chair \\ Amy Weislogel, Ph.D. \\ Tim Carr, Ph.D. \\ Department of Geology and Geography \\ Morgantown, West Virginia \\ 2016
}

Keywords: fluid inclusions, halite, gypsum, Northern Ireland, Mercia Mudstone, Larne Halite Member, laser Raman spectroscopy, Freezing-melting microthermometry, acid, saline

Copyright (C) 2016 Lynnette Eichenlaub 


\section{ABSTRACT \\ A fluid inclusion study of acidity in bedded halite of the Larne Halite Member, Triassic Mercia Mudstone Group from the Carnduff 2 Core, County Antrim, Northern Ireland}

\section{Lynnette Eichenlaub}

The Carnduff 2 core, drilled in 2014 by the Gaelectric Storage Limited Energy Company in County Antrim, Northern Ireland contains Triassic red mudstones and evaporites of the Mercia Mudstone Group. These rocks have been poorly studied in Northern Ireland. However, recent work suggests that they were deposited in an ancient perennial saline lake system. This thesis describes a 591.6 meter core with $92.7 \%$ recovery. Fluid inclusion petrography, microthermometry, and laser Raman spectroscopy were conducted on 12 halite beds of the Larne Halite Member to characterize Triassic lake waters.

Chevron and cumulate halite crystals contain abundant unaltered primary fluid inclusions. Most primary fluid inclusions are all liquid, but there are also fluid inclusions that contain daughter crystals. Petrographic studies showed that primary inclusions have a double rim. This double rim is not seen on fluid inclusions with neutral $\mathrm{pH}$. This suggests that double rims may be a new criterion for determining acidity. Fluid inclusions failed to freeze during freezing-melting microthermometry, even after being exposed to $-190^{\circ} \mathrm{C}$ for several minutes. The failure to freeze during microthermometry runs is likely due to low $\mathrm{pH}$ and/or extremely high salinity. Laser Raman spectroscopy of 45 inclusions showed peaks for bisulfate and/or aluminum sulfate compounds in 10 of the 12 beds, indicating high sulfate and aluminum in solution. More importantly, such peaks are characteristic of waters having $\mathrm{pH}$ values $<\sim 3$.

This study provides evidence for the first time that bedded halite of the Mercia Mudstone Group of Northern Ireland formed in acid, saline lakes. Additionally, new criteria for determining low $\mathrm{pH}$ in the rock record has been established. Finally, this study suggests that, when compared to Permian acid brine deposits of North America, the red beds and evaporites of the Triassic Mercia Mudstone Group of Northern Ireland may be part of spatially extensive and long-lasting, acid saline environments of Pangea. 


\section{Acknowledgements}

This project would not have been possible without guidance, support, and funding of Dr. Kathleen Benison. I would like to thank her for her dedication to helping me grow as a scientist and the countless hours she spent helping me to succeed. I would also like to thank my committee members, Dr. Amy Weislogel and Dr. Tim Carr for taking time out of their extremely busy schedules to offer insights and edits to my thesis. Dr. Robert Raine of the Geological Survey of Northern Ireland and Dr. Stephen Aherne of the Gaelectric Storage Limited Energy Company are thanked for allowing me to have access to their core repository and to sample the Carnduff 2 core respectively. Without their kindness and support, I would not have been able to make detailed descriptions of the core as a whole, and would not have been able to take such excellent samples back to West Virginia University for detailed analyses. Likewise, I would like to thank the Shared Research Facilities at West Virginia University for allowing me to have access to the MCF-Raman spectroscopy, and would like to thank Weiqiang Ding for providing training and assistance on the laser Raman spectrometer. I would also like to thank, Bob Burruss, Beth Gierlowski Kordesch, Helen Lang, Sean Brennan, and Tim Lowenstein for their insights and research discussions.

A tremendous thank you also goes out to Sofia Andeskie who aided in this research project during all phases of its completion. From start to finish, we have worked together to make this project and hers the best that they could be. I am infinitely grateful for the time spent together making observations and bouncing ideas off each other, and helping each other grow as scientists. 
I would like to thank my family for always being a positive support system as I have gone through this journey. I thank my closest companion, Charley for always greeting me with a wagging tail and making me smile. Miles Reed is thanked for always offering support and lending an ear when I needed advice. Many thanks go to Brett McLaurin for always being patient, kind, and one of the most influential people during my early days as a geology student. Finally, I would like to thank my brother (Clayton King), mother (Brenda Eichenlaub), and my father (Craig Eichenlaub) for their endless love and support throughout my whole life both as a person and as a scientist. I would not have been able to do this without them all cheering me on along the way. 
For Craig and Brenda Eichenlaub 


\section{Table of Contents}

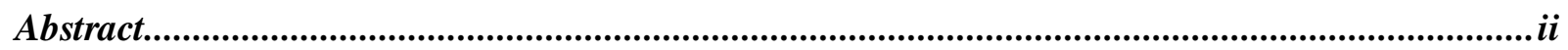

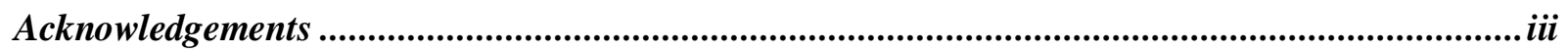

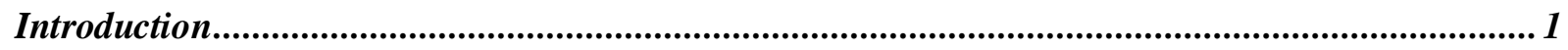

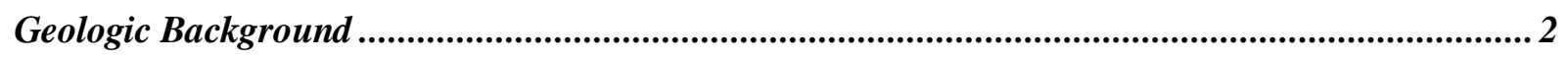

Previous Work on the Mercia Mudstone Group .....................................................................2

Tectonic Setting........................................................................................................................... 4

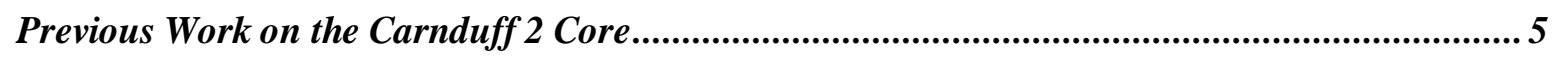

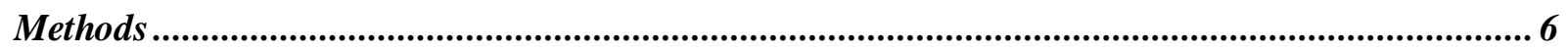

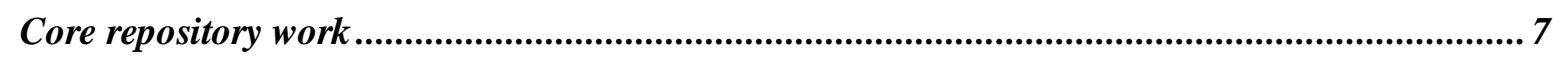





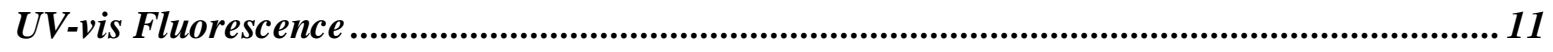

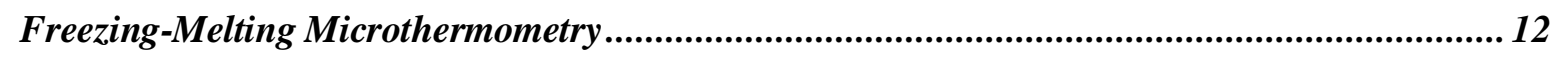

Laser Raman Spectroscopy ….................................................................................................... 13

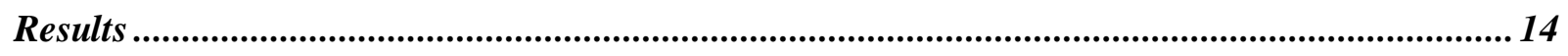

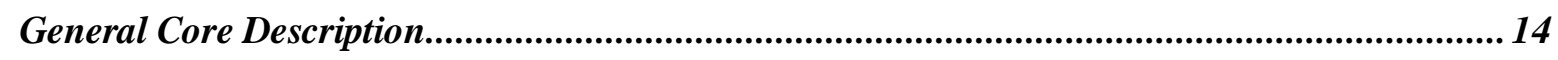

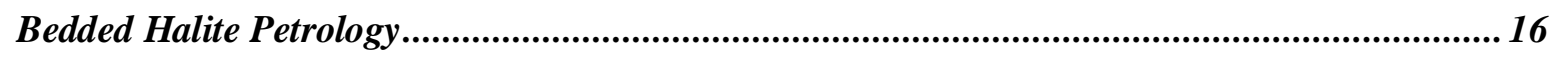

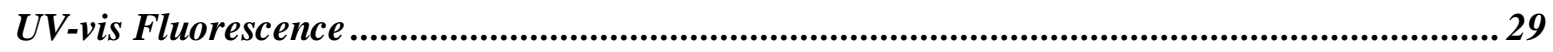

Freezing-Melting Microthermometry ........................................................................................ 30

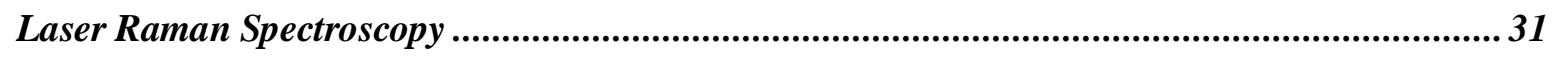

Laser Raman spectroscopy of accidental daughter crystals in fluid inclusions ........................... 37 




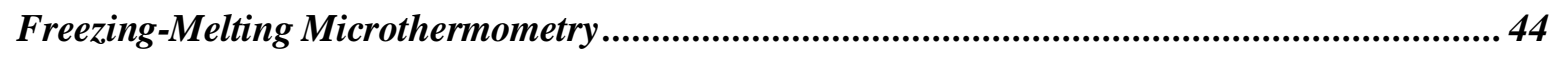

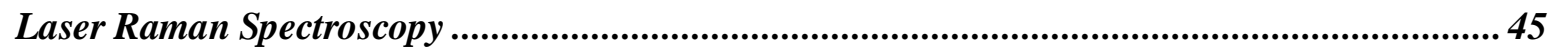

How do the Larne Halite fluid inclusions compare to Modern Salar Gorbea Waters? ...... 47

How do the Larne Halite fluid inclusions compare to Lake Aerodrome Waters? ............... 47

How does the Larne Halite compare to Permian Opeche Fluid Inclusions? ...................... 48

How does the Larne Halite compare to Permian Nippewalla Fluid Inclusions? ................ 48



How is hydronium alunite an indicator of acidity in ancient environments?.....................50



Was the Larne Halite deposited in acid lake waters?..................................................................51

How do the waters of the Larne Halite compare to those found in other ancient and modern acid,

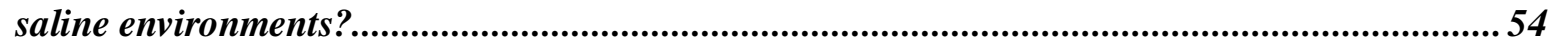

What is the microbiology of the Larne Halite lakes?.....................................................................55

What does Mercia Mudstone reveal about the temporal and spatial extent of acid, saline environments in Pangea? ..........................................................................................................56

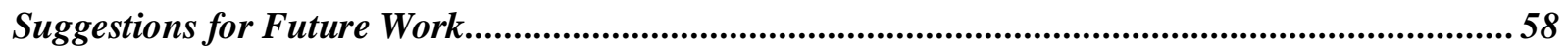

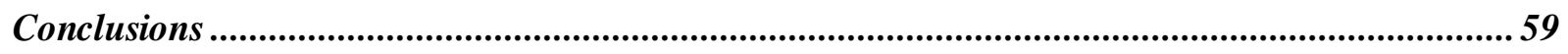

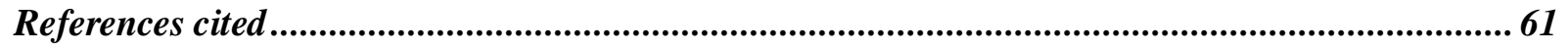

Appendix A: Stratigraphic Descriptions of the Mercia Mudstone Group in the Carnduff 2 core. ... 66

Appendix B: Measured Section of the Carnduff 2 Core ..................................................................... 97

Appendix C: Fluid Inclusion Petrography................................................................................ 100 
Appendix D: Microthermometric Data ........................................................................................ 143

Appendix E: Laser Raman Spectroscopy Data.............................................................................. 145 


\section{Introduction}

Acid, saline, hot, dry, and windy conditions have been interpreted for Permo-Triassic red beds and evaporites deposited in lake-mudflat-dune-desert soil systems (e.g. Benison and Goldstein 2000, 2001; Benison et al., 1998). In particular, these acid saline environments have been identified from the Permian Nippewalla Group of Kansas and Oklahoma, and the Permian Opeche Shale of North Dakota (Benison et al., 1998; Benison and Goldstein, 1999; Sweet et al., 2013; Zambito and Benison, 2013). However, the spatial and temporal extent of acid-saline lake and groundwater systems in Pangea remains unknown.

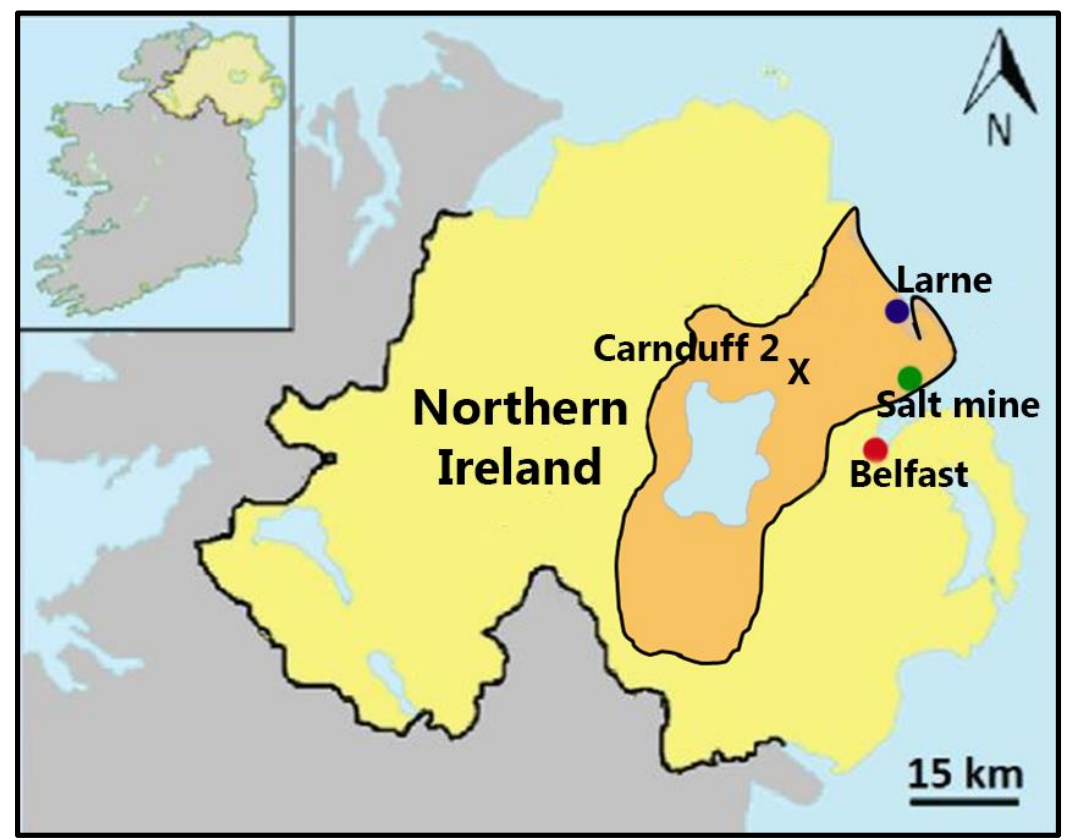

Figure 1. Approximate location of the Carnduff 2 drilling site. After drilling, the core was stored in the Geological Society of Northern Ireland's core repository in Belfast. The orange area indicates the approximate boundaries of the Larne-Lough Neagh basin. Modified from Andeskie et al. (2015). 
Red beds and evaporites of the Triassic Mercia Mudstone Group of the Larne-Lough Neagh Basin in Northern Ireland may help address the problem of spatial and temporal extent of acid saline lake systems in Pangea. A complete section of the Mercia Mudstone is contained in the The Carnduff 2 core, drilled in 2014 near Larne, County Antrim, Northern Ireland (Fig.1).

The objective of this thesis is to conduct fluid inclusion studies on the bedded halite of the Larne Halite Member of the Mercia Mudstone Group in the Carnduff 2 core to test for acidity. This study uses petrography, microthermometry, and laser Raman spectroscopy of primary fluid inclusions to interpret depths, salinity, $\mathrm{pH}$, and general composition of Triassic lake waters.

\section{Geologic Background}

\section{Previous Work on the Mercia Mudstone Group}

The Triassic Mercia Mudstone Group has been recognized for its economic significance as a seal for the Sherwood Sandstone Group, the second largest gas reservoir in the United Kingdom (Geological Survey of Northern Ireland, 2004; Armitage et al., 2015). Most studies have taken place in the Cheshire Basin of England and have focused on the stratigraphy and general lithologies (Arthur, 1973; Benton et al., 2002; Holliday et al., 2005; McCann 1990; Ruffell and Shelton 1999). Other studies include describing the stratigraphy and analyzing and correlating seismic logs of the Mercia Mudstone Group in the East Irish Sea Basin and North Sea Basin (Arthur, 1973; Benton et al., 2002; Holliday et al., 2005; McCann 1990; Ruffell and Shelton 1999).

The Mercia Mudstone Group, also known as the Keuper Marl in the older literature, has previously been described as predominately mudstone, varying in color from red to brown and 
green to grey, with rare sandstone and siltstone beds (Armitage et al., 2015; Arthur 1973; Elliot, 1961; Geological Survey of Northen Ireland, 2011; Howard et al., 2008; McCann, 1990; Smith, 1971). Grey reduction spots, thick halite members, and dolerite intrusions were also noted as characteristic features of the Mercia Mudstone in cores from the Larne-Lough Neagh Basin (McCann, 1990). Common gypsum and anhydrite beds also exist in England (Armitage et al., 2015). However, detailed descriptions of lithologies in Northern Ireland have not yet been made. One of the few studies on the Mercia Mudstone Group in Northern Ireland compared five exploration holes between Larne and Belfast, but yielded inaccurate data due to dissolution of some of the salt from drilling (McCann, 1990).

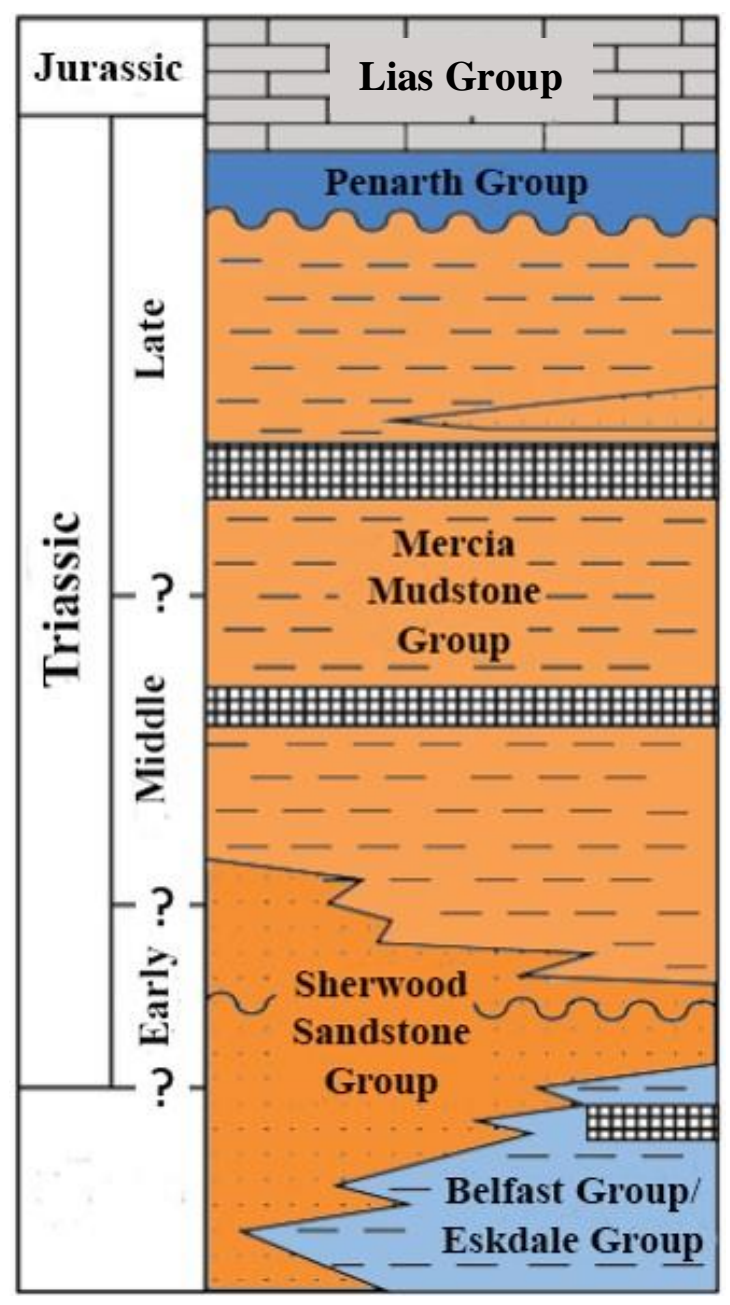

Figure 2. Simplified stratigraphic column showing the lithologies found in the United Kingdom and Northern Ireland. The Carnduff 2 core contains the Mercia Mudstone, and Penarth Groups. Modified from Benton et al. (2002) and Mitchell (2004). 
The underlying Permian Sherwood Sandstone Group consists of thick sequences of red crossbedded sandstones that have been interpreted as both eolian and fluvial deposits (Benton et al., 2002; Geological Survey of Northern Ireland, 2004; Howard et al., 2008). The Penarth Group overlies the Mercia Mudstone and consists of fossiliferous marine limestones (Benton et al., 2002; Fig. 2). Evaporites and fine-grained red beds of the Mercia Mudstone Group make it distinct from the underlying Sherwood Sandstone Group and the overlying Penarth Group.

\section{Tectonic Setting}

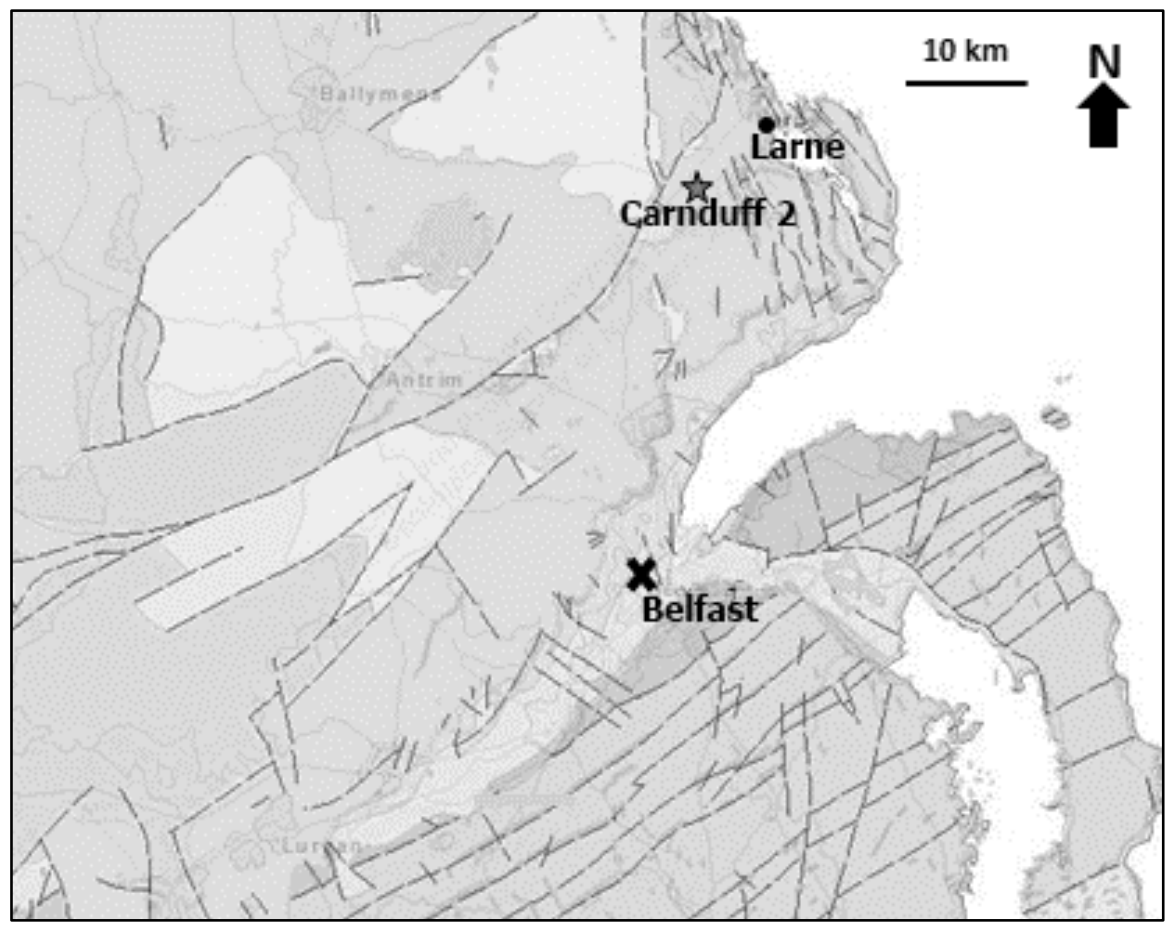

Figure 3. Structural map of Belfast area showing the Carnduff 2 core drilling site. Dark lines are faults. Note that the Carnduff 2 core was drilled in an unfaulted area. Image modified from the GSNI Geoindex (2011).

The tectonic setting during the Triassic Period of Northern Ireland has not been resolved. One study suggests that there was a syn-rift phase of crustal extension during the deposition of the Sherwood Sandstone Group and the beginning of deposition of the Mercia Mudstone Group (Ruffel and Shelton, 1999). However, another study suggests that the Mercia Mudstone Group 
was not deposited until after rifting had concluded (Howard et al., 2008). Furthermore, structural maps have noted faulting in Northern Ireland since rifting ended, but not in the area where the Carnduff 2 core was drilled (Fig. 3; McCann, 1990; Ruffel and Shelton, 1999). Tertiary igneous intrusions cut across the Mercia Mudstone Group of County Antrim, Northern Ireland (Penn et al., 1983). The rifting history during the time of deposition of the Mercia Mudstone Group remains unresolved. This makes it possible that tectonic activity was not a major influence on the Mercia Mudstone Group in the Larne-Lough Neagh Basin.

\section{Previous Work on the Carnduff 2 Core}

The Carnduff 2 core was drilled in July, 2014 in County Antrim, Northern Ireland by Gaelectric Storage Limited Energy Company. This core was drilled for exploration for a compressed air energy storage project (Gaelectric Storage Limited Energy Company, projectCAES Larne Information Packet, 2016; Rob Raine, personal communication). The topmost part of the core was drilled with fresh water, but upon hitting evaporites at depth of 629.8 meters, a halite-saturated saline solution was used for the remainder of drilling. The use of a saline solution allowed for an excellent recovery rate of $92.7 \%$ between the depths of $970-378.4$ meters, the entire length of the Mercia Mudstone Group.

The Mercia Mudstone Group of the Carnduff 2 core has recently been interpreted as a perennial, shallow, saline lake system by Andeskie (2016). Bedded halite and gypsum were deposited in shallow saline lakes. Displacive halite was formed in saline mudflats as halite grew from shallow, saline groundwater hosted by red mud. The mudstone and siltstone lithofacies were described as dry mudflats and siltflats surrounding the lake. Finally, some mudstone and siltstone lithofacies were interpreted as paleosols because they contain soil slickensides, blocky 
peds, and circumgranular cracks (Andeskie, 2016). Abundance of iron oxides and evaporites, with no obvious fossils or carbonates, may suggest that lake waters and groundwaters were extremely saline and/or acidic.

Bedded halite and gypsum lithologies were interpreted as deposits of shallow perennial saline lakes that were rich in $\mathrm{Na}, \mathrm{Cl}, \mathrm{Ca}$, and $\mathrm{SO}_{4}$ (Andeskie et al., 2015). The presence of chevron halite crystals suggests that the lake waters were less than $\sim 0.5$ meters deep (Arthurton, 1973). Evidence of flooding and evapoconcentration can be seen in these bedded evaporites. Evapoconcentration of a surface water body is shown by the precipitation of bedded evaporites. Andeskie (2016) states that the surface dissolution of bedded evaporite minerals (shown by dissolution pits and pipes) along with the presence of mud drapes, climbing ripples, and cross bedding in associated red beds are all indicative of flooding of lakes with less saline waters.

\section{Methods}

The main methods for conducting this research were petrography, freezing-melting microthermometry, and laser Raman spectroscopy of fluid inclusions in bedded halite of the Larne Halite Member. Besides studying the Mercia Mudstone, I also looked at synthetic and natural fluid inclusions and lake waters from Permian and modern lakes to compare and contrast their chemistries to my findings. I conducted analyses on these fluid inclusions and lake waters and also referred to some publications for comparisons to the Larne Halite fluid inclusions. Synthetic fluid inclusions in halite were grown from $\mathrm{Na}_{2} \mathrm{SO}_{4}-\mathrm{H}_{2} \mathrm{SO}_{4}-\mathrm{NaCl}-\mathrm{H}_{2} \mathrm{O}$ solutions

(Benison et al., 1998). Natural fluid inclusions were from the Permian Opeche Shale and Nippewalla Group of North Dakota and Kansas (Benison et al., 1998). Modern lake waters were 
collected from $\mathrm{pH}$ 1.8 Salar Gorbea, Chile and $\mathrm{pH}$ 1.8 Lake Aerodrome and $\mathrm{pH}$ 1.4 Gneiss Lake in Western Australia (personal communication, K.Benison).

This study was conducted in two locations. The first portion took place in the Geological Survey of Northern Ireland's Core Repository in Belfast, Northern Ireland. The second half of this study took place at West Virginia University, Morgantown, West Virginia.

\section{Core repository work}

Based on a reconnaissance trip by Dr. Kathleen Benison to the Geological Survey of Northern Ireland (GSNI) in 2014, the Carnduff 2 core was identified for study because the core was in excellent condition, was stratigraphically complete, and resembled known Permian acid cores. In the summer of 2015, my team (Sofia Andeskie, Dr. Kathleen Benison, and I) was given full access to the Carnduff 2 (aka GESC 2) core. During this time, we slabbed for the first time and made a detailed description of the core. During slabbing, careful attention was paid to make sure that limited water was dripped on the back of the saw blade, but not on the sample. By doing this, dissolution of halite during cutting was limited.

Core depths of 970 meters to 378.4 meters were selected for detailed observation because they were the constraints of the Mercia Mudstone Group (Fig. 4). Of the 591.6 meters of the Mercia Mudstone within the Carnduff 2 core, 548.4 meters were recovered and 43.2 meters were missing, yielding a recovery of $92.7 \%$. This allowed for detailed, representative features to be noted and described.

The Carnduff 2 core was described and measured in collaboration with Sofia Andeskie during the summer of 2015 in Belfast, Northern Ireland. The outer and slabbed surfaces of the core were observed and photographed. Rock type, color, sedimentary structures, contacts, fossils, 
and diagenetic features were noted. We also tested for the presence of any carbonates with hydrochloric acid. Representative samples were scanned and carefully packaged to be shipped to West Virginia University for more detailed study.
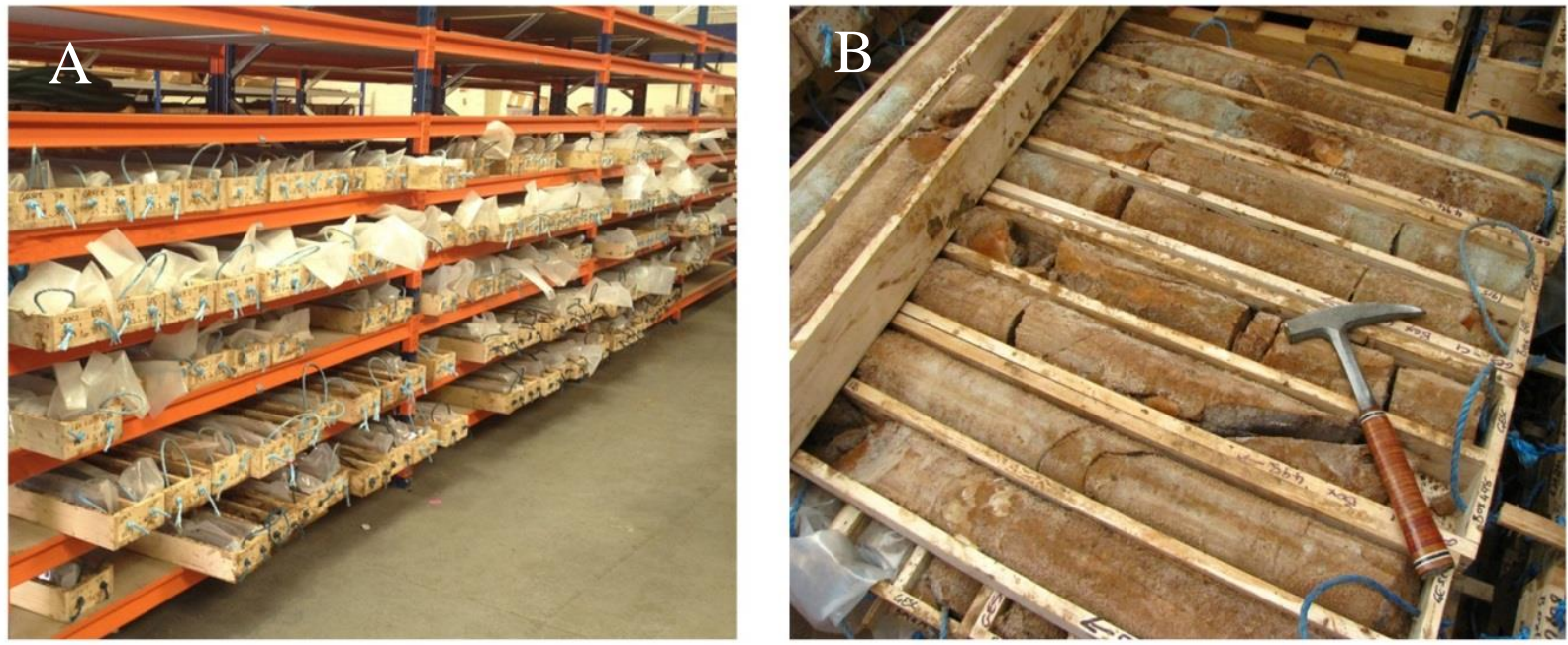

Figure 4. Core in GSNI core repository in Belfast. A) Boxes of the Carnduff 2 core were organized and stored on shelves in the GSNI core repository. Note that the cores are wrapped in sealed plastic bags in order to prevent dissolution of evaporite minerals. B) Red beds and evaporites can be seen once core segments are removed from their protective plastic bags.

After observations of the core were made, a measured section of the Carnduff 2 core from depths of 970 meters to 378.4 meters was completed (Appendix A; Andeskie et al., 2015). Through observations, the core was divided into nine lithologies. The detailed depositional environments and diagenetic history of the core was the basis of the Master's thesis of Anna Sofia Andeskie (2016).

\section{Halite Sample Preparation}

Within the Larne Halite Member (938.4-659.5 meters), 43 halite beds were identified. Of those 43 beds, 29 were greater than 0.5 centimeters thick. Of these 29 beds, 12 were chosen for analyses. These beds were chosen because they were the thickest bedded halite units where distinct cloudy halite, rich in primary fluid inclusions, were seen. Halite crystals were prepared 
by cleaving with a razor blade and polishing manually using sandpaper with grit values of 220 , 400, 600, 1200, 2000, 3000, and 5000. Prepared halite chips ranged in width from $\sim 1.25$ millimeters to $\sim 2.1$ centimeters and were approximately $0.5 \mathrm{~mm}$ thick. This study relied on the integrity of fluid inclusions. Therefore, it was essential that the fluid inclusions remained unaltered during the chip preparation process. Before analyzing these chips, preliminary petrographic observations were made to ensure that the chips were sanded and polished to an appropriate thickness and that fluid inclusions within the chips were appropriate for petrographic observations and analyses.

\section{Petrography}

Two microscopes were used for fluid inclusion petrographic observations: an Olympus SZX10 binocular microscope and an Olympus BX53 microscope. The Olympus SZX10 is equipped with plane transmitted light, reflected light, polarized light, magnification range of $6.3 \mathrm{x}$ to $63 \mathrm{x}$, and a digital camera with SPOT 5 imaging software. Similarly, the Olympus BX53 has plane transmitted light, reflected light, polarized light and a digital camera with SPOT imaging software. In addition, it has a UV-vis light source and magnification range of 40x to 2000x.

Initial petrographic observations of twelve beds of halite in the Mercia Mudstone were conducted to look for primary fluid inclusion assemblages (FIA) to determine the suitability for fluid inclusion analyses. Fluid inclusion assemblages are defined by Goldstein and Reynolds (1994) as "the most finely discriminated group of petrographically associated fluid inclusions that formed at about the same time, or during the same set of (depositional or) diagenetic conditions". Primary fluid inclusions in halite are those that have a negative crystal shape and exist along growth bands oriented parallel to crystal faces. Primary fluid inclusions contain 
waters that were trapped during the initial growth of the halite crystal (Fig. 5; Goldstein and Reynolds, 1994).

Fluid inclusion assemblages that are found along curved surfaces and cut across growth bands or crystal boundaries are secondary and pseudosecondary FIAs, and are not good candidates for evaluation of depositional waters (Fig 5; Goldstein and Reynolds, 1994; Goldstein, 2003). Another category of fluid inclusions that are not suitable for parent water chemistry studies are isolated fluid inclusions. These inclusions are not in close association with other inclusions, are generally larger than primary fluid inclusions, and may be irregularly shaped. Secondary, pseudosecondary, and isolated fluid inclusions were not subjected to freezing-melting runs or laser Raman spectroscopy. Unaltered primary fluid inclusions were targeted for further petrographic observations, freezing-melting runs, and laser Raman spectroscopy.

Halite is considered a vulnerable host mineral (Benison and Goldstein, 1999), therefore attention was paid to the inclusions to ensure that they had not been altered. Only primary, unaltered fluid inclusions were used in this study. Examples of alteration include stretching, leaking, and necking (Benison and Goldstein, 1999; Goldstein and Reynolds, 1994; Goldstein, 2003; Fig. 5). Stretching, leaking, and necking of inclusions all change the shape and volume of the inclusion. This is not a problem for chemical analyses of liquid in inclusions. However, it changes the ratio of liquid to any vapor, and therefore may prevent accurate homogenization temperature from being measured (Goldstein and Reynolds, 1994).

After primary fluid inclusions were found within each sample, they were then described in detail. Observations included size, shape, orientation along growth bands, and inclusion phases. Petrographic observations also included making detailed sketches and notes of all halite 
chips observed, creating detailed maps of the crystals, and photographing crystal chips and fluid inclusions.


Figure 5. Schematic views of types of fluid inclusions in halite. A) Primary, secondary/psuedosecondary, and isolated fluid inclusions. B) Unaltered primary fluid inclusions. C) Necked fluid inclusion. D) Leaked fluid inclusion. E) Stretched fluid inclusions.

\section{UV-vis Fluorescence}

During petrographic observations, a combined $330 \mathrm{~nm}$ and $385 \mathrm{~nm}$ UV-vis light source was used with the Olympus BX53 microscope to detect any fluorescence, which might indicate organic matter or hydrocarbons. The entire crystal was first observed with transmitted light, then a combination of transmitted and UV light was used to indicate possible areas of organics. In some instances, the use of a combination of transmitted and UV light was enough to detect organic materials. A blue, yellow, or yellow/green fluorescence emitted from the crystal, indicated possible algae and prokaryotes (Benison and Karmanocky, 2014; Connor and Benison, 2013; Schubert et al., 2010). In other instances, UV light alone was needed to show fluorescence of organic materials. Any area that fluoresced in the crystal when viewed at low magnification 
was then magnified for closer observations. In the rare instances where fluorescence occurred, detailed notes and photographs were taken.

\section{Freezing-Melting Microthermometry}

Microthermometry includes warming or cooling fluid inclusions and observing the phases present at different temperatures. This allows for temperatures and compositions of parent waters to be calculated (Davis et al., 1989; Goldstein and Reynolds, 1994; Hayes, 1985).

Unaltered primary fluid inclusion assemblages were selected from each of the twelve halite beds for freezing-melting runs. Freezing-melting runs were conducted on a Fluid, Inc. U.S.G.S. modified gas-flow heating/cooling stage, which is widely used for its accuracy $\left( \pm 0.1^{\circ}\right.$ C; Goldstein and Reynolds, 1994). The heating/cooling stage was connected to an Olympus BX53 microscope equipped with a digital imaging system to allow for photo documentation of each inclusion during the freezing-melting process. During this process, the fluid inclusions were frozen with liquid nitrogen, then allowed to gradually warm as observations were made.

Before the freezing-melting cycles took place, the stage's thermocouple was calibrated approximately once every six months. An ice bath confirmed a temperature of $0^{\circ} \mathrm{C}$ and calibration of $\mathrm{CO}_{2}$ synthetic inclusions were used to confirm a melting burst at $-56.6^{\circ} \mathrm{C}$. These two calibration temperatures resemble the approximate range of freezing-melting behavior anticipated for fluid inclusions in halite.

When conducting freezing-melting runs, a single halite chip is placed in the heating/cooling stage and held in place by the thermocouple. Fluid inclusions near the thermocouple are selected for observation. After focusing on an inclusion, liquid nitrogen is pumped through the inclusion stage to freeze the inclusion. Once an inclusion freezes, the stage 
is slowly warmed. Written observations and photographs are taken to document various phases at different temperatures. Typically, a minimum of three cycles of freezing- melting runs are conducted for each inclusion to ensure accurate measurements of phase changes as well as account for metastability within any inclusions (Goldstein and Reynolds, 1994; Benison and Goldstein, 1999; Jagniecki and Benison, 2010; Haynes, 1985).

\section{Laser Raman Spectroscopy}

Laser Raman spectroscopy was used to help characterize covalently bonded compounds in fluid inclusions in halite. In laser Raman spectroscopy, a laser is focused down a microscope, and the sample is analyzed using focused light and inelastic scattering of light (Frezzotti et al., 2012; Pasteris et al., 1987; Rosasco and Roedder, 1979). A micron-wide beam of light is aimed at a specific phase in the sample and emits a spectrum of light intensity. This technique has gained popularity in recent years for fluid inclusion analyses. This is, in part, due to its nondestructive nature and ease of use with in situ analyses of micron-scale solids, liquids, and gases (Benison et al., 1998; Frezzotti et al., 2012; Rosasco and Roedder, 1979; Verkaaik et al., 2015). Laser Raman spectroscopy works particularly well on fluid inclusions in halite because it only detects the vibrations of covalently bonded compounds. Because halite is ionically bonded, the solids, liquids, and gases within the fluid inclusions can be analyzed without any interference from the encompassing mineral (Benison et al., 2008). By observing peak positions and character, the speciation of fluids and, in some cases, their concentrations, can be determined (Benison et al., 1998).

All laser Raman analyses took place in a Shared Research Facilities lab at West Virginia University. Unmounted halite chips were analyzed using a Renishaw MCF-RAMAN 
spectrometer equipped with 40x and 100x long-working distance objectives, and a green, $532 \mathrm{~nm}$ laser. Analyses were conducted at 25 passes for 10 seconds. Early in the study the laser was at $11 \%$ power. After replacement of a new laser, analyses were done at $100 \%$ power. Only minor differences were noted between $11 \%$ and $100 \%$ laser power. To ensure accurate readings were being collected, the instrument was calibrated at the start and end of each day using a standard

silicon wafer with a $521 \mathrm{~cm}^{-1}$ Raman peak. If the run time of the instrument was anticipated to be longer than four hours, a third calibration was done in the middle of the session to test for any drift in detection. Besides Larne Halite samples, synthetic and natural halite chips with fluid inclusions of different known $\mathrm{pH}$ values were analyzed for comparison.

\section{Results}

\section{General Core Description}

Bedded halite, bedded gypsum, mudstone, siltstone, sandstone, mud/halite conglomerate, displacive halite, undifferentiated evaporates, and igneous intrusions were all lithologies found in the Mercia Mudstone Group of the Carnduff 2 core. Mudstone was by far the most abundant lithology, consisting of $34.4 \%$ of the Mercia Mudstone, followed by displacive halite making up $25.5 \%$ of the Mercia Mudstone (Table 1).

Bedded halite made up $8.3 \%$ of the Mercia Mudstone with a total thickness of 49.3 meters (Fig. 6). All of the bedded halite found within the Mercia Mudstone Group is included in the Larne Halite Member. 




Table 1. The absolute and relative thickness values for each of the lithologies observed in the Carnduff 2 core. Mudstone and displacive halite are the most dominate lithologies seen. Coarser grained silicilastics such as sandstone, siltstone, and conglomerate were less abundant.

Core slabs from 43 depths containing bedded halite samples were shipped to the laboratory at West Virginia University (Fig. 7). Of those 43 samples, 14 contained beds that were less than 0.5 centimeters in depth. These samples were not included in study because of the difficulty of preparing such small samples. From the 29 remaining beds, 12 beds of bedded halite (41.4\% of samples with crystal beds $>0.5 \mathrm{~cm}$ in thickness) were chosen for analyses. These 12 beds were chosen because they represent the thickest halite units and contained cloudy halite. Cloudy halite is typically rich in primary fluid inclusions; therefore, cloudy halite beds were most likely to be abundant in primary inclusions for analyses. 


\section{Bedded Halite Petrology}

Bedded halite accounted for $8.3 \%$ of the total Mercia Mudstone Group in the Carnduff 2 core (Fig. 6). Bedding was defined mainly on the basis of crystal shape and crystal orientation. Bedded halite was identified as units composed of chevron and/or cumulate crystals. Crystals identified as chevrons were approximately 1-centimeter-wide and approximately 3-5 centimeters tall. The corners of their growth bands formed points that were oriented upward from the sediment-water interface. Each chevron had cloudy, inclusion-rich growth bands that alternated with clear, inclusion-free bands. Cumulate crystals were identified as those that were cube shaped with alternating cloudy, inclusion-rich and clear, inclusion-free bands. Cumulate growth bands formed square shaped growth bands inside the crystal. In some instances, several cumulate crystals were seen attached to each other as cumulate rafts.

The color of the halite beds in the core varied with the abundance of mud found within the beds. Beds that contained more mud had darker, less transparent beds than those that contained less mud. The crystals forming the beds were predominately chevron crystals; however, numerous cumulates were also noted (Fig. 7C). Mud varied in color from reddish brown (10R 4/4) to chocolate brown (2.5YR 3/3) to grey (Gley 2 5/10BG). Because of the mud's influence on the crystal color, the color of halite in the core also varied. The range of colors were: clear, pink (2.5 YR 7/6 and 2.5YR 7.8), brown/tan (2.5YR 2.5/2 and 7 YR 6/4), pink/orange (7.5YR 7/8), and chocolate brown (2.5YR 4/4) (Fig. 7). Mud was found in $81 \%$ of all bedded halite, usually in the form of mud drapes. The amounts of mud varied from as low as $5 \%$ to as high as $20 \%$ in some beds, but the estimated amount of mud was $5-10 \%$ for most beds. 


\section{Carnduff 2 Core}
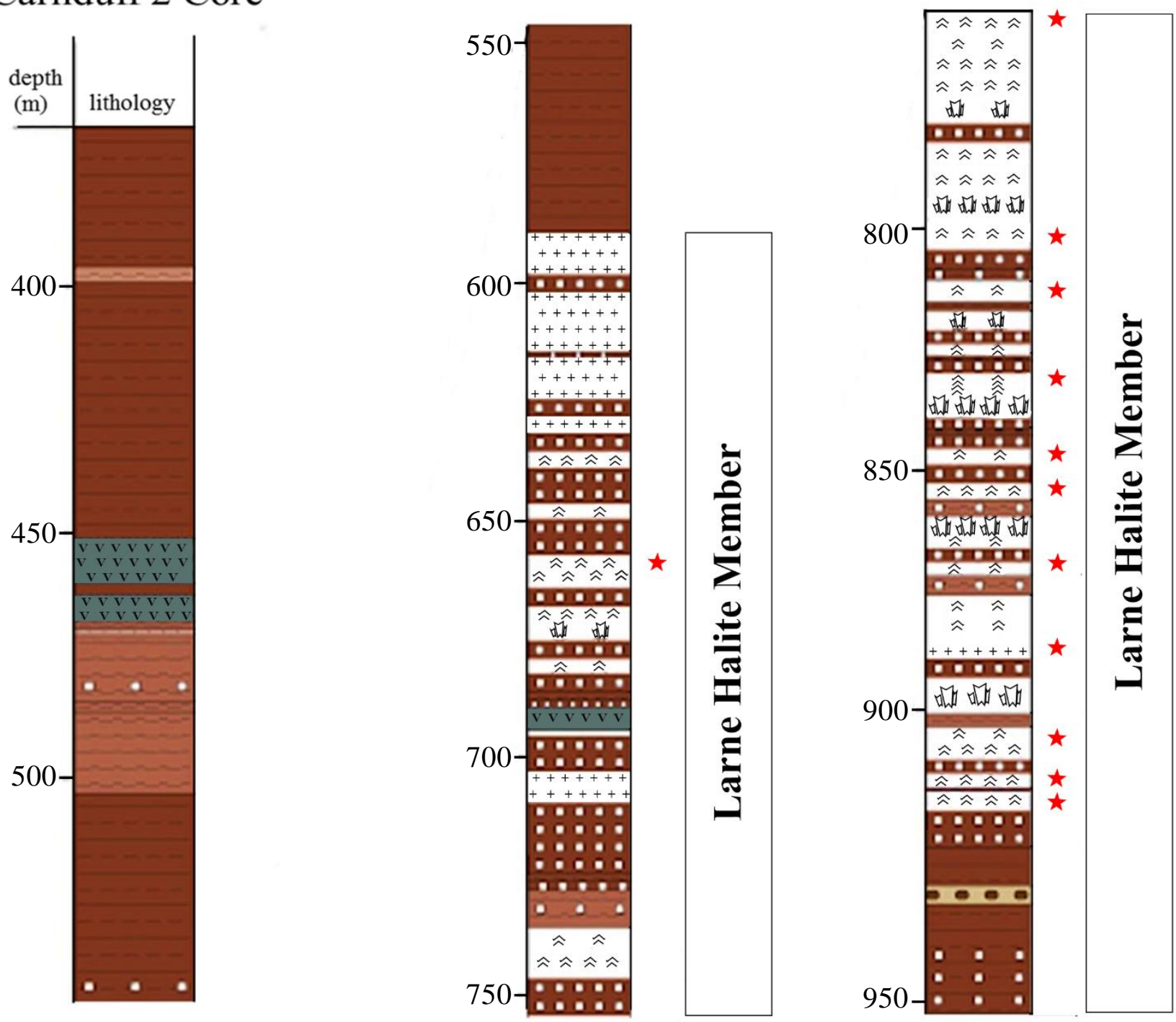

Main lithologies:
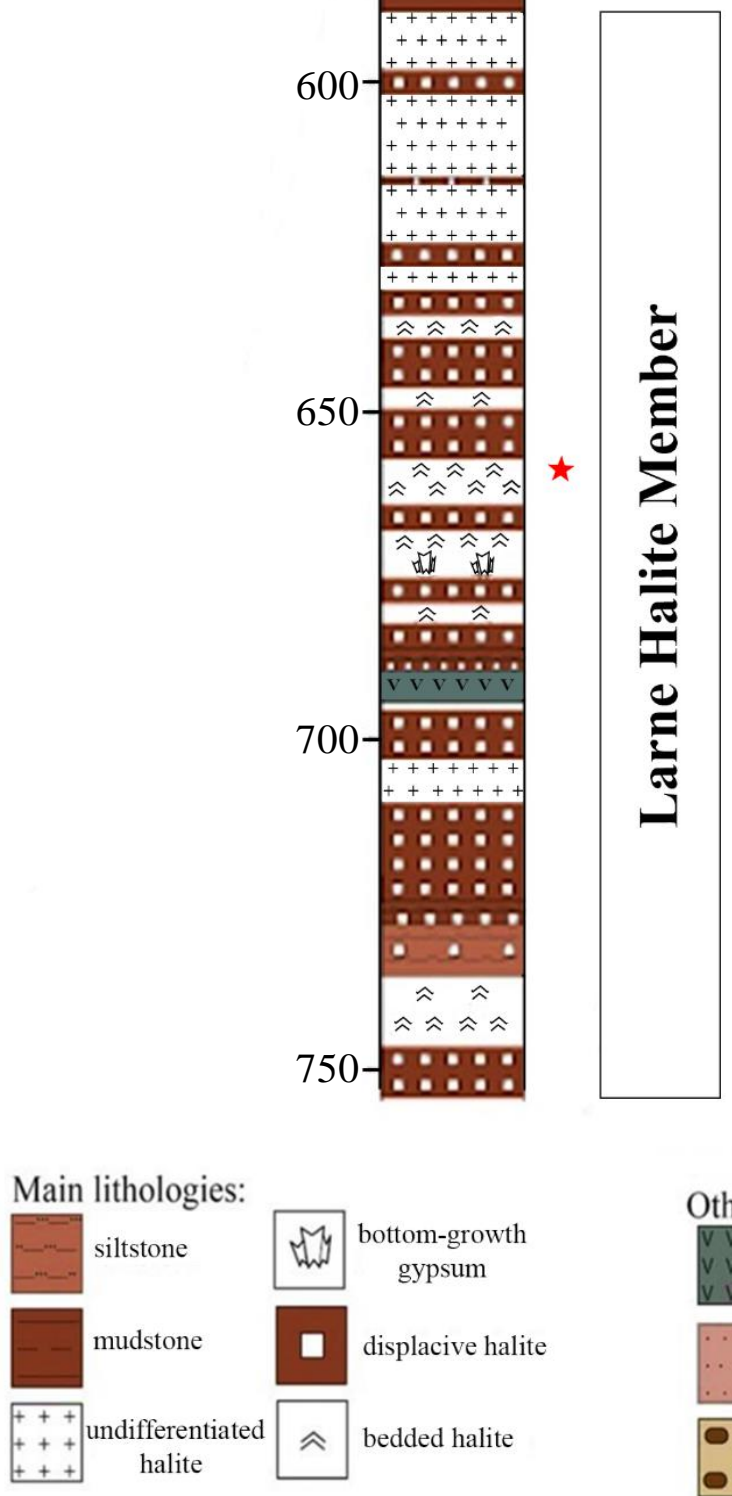

Other lithologies:
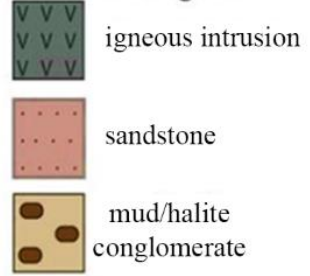

Figure 6. Stratigraphic column for the Mercia Mudstone Group in the Carnduff 2 core from County Antrim, Northern Ireland. The red stars represent the twelve depths at which halite samples were used for this study. Modified from Andeskie (2016), but constructed based on collaborative core descriptions at GSNI. 

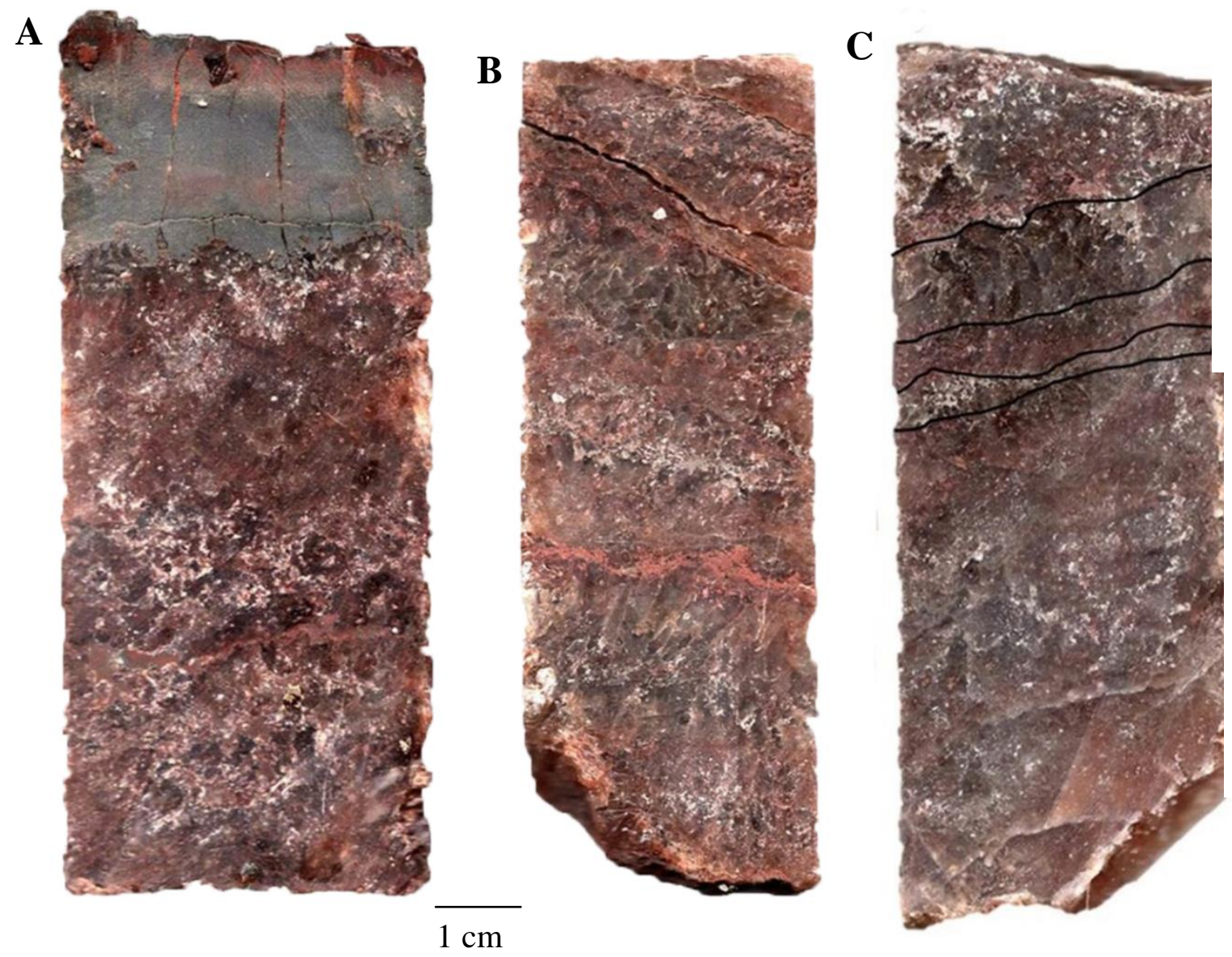

Figure 7. Photographs showing bedded halite in the Carnduff 2 core. A) Bedded halite at 813.7 meters depth showing the influence of mud on halite color in the core. B) Alternating halite beds at 843.2 meters depth outlined by mud drapes. C) Bedded halite crystals at a depth of 881.7 meters that are differentiated from displacive halite crystals by their lower mud content and their distinct upward growing crystal shape. Bedded halite crystals are outlined. All photographs are oriented stratigraphically up. 
Petrography was conducted on twelve representative beds of halite within the Carnduff 2

core occurring at depths of: 660.0-659.5, 768.0-766.9, 805.5-804.8, 807.0-805.6, 817.5-815.5, 820.1-819.6, 842.1- 841.5, 864.0-862.4, 887.7-887.0, 906.6-906.1, 919.6-919.1, and 939.0-938.4

meters.
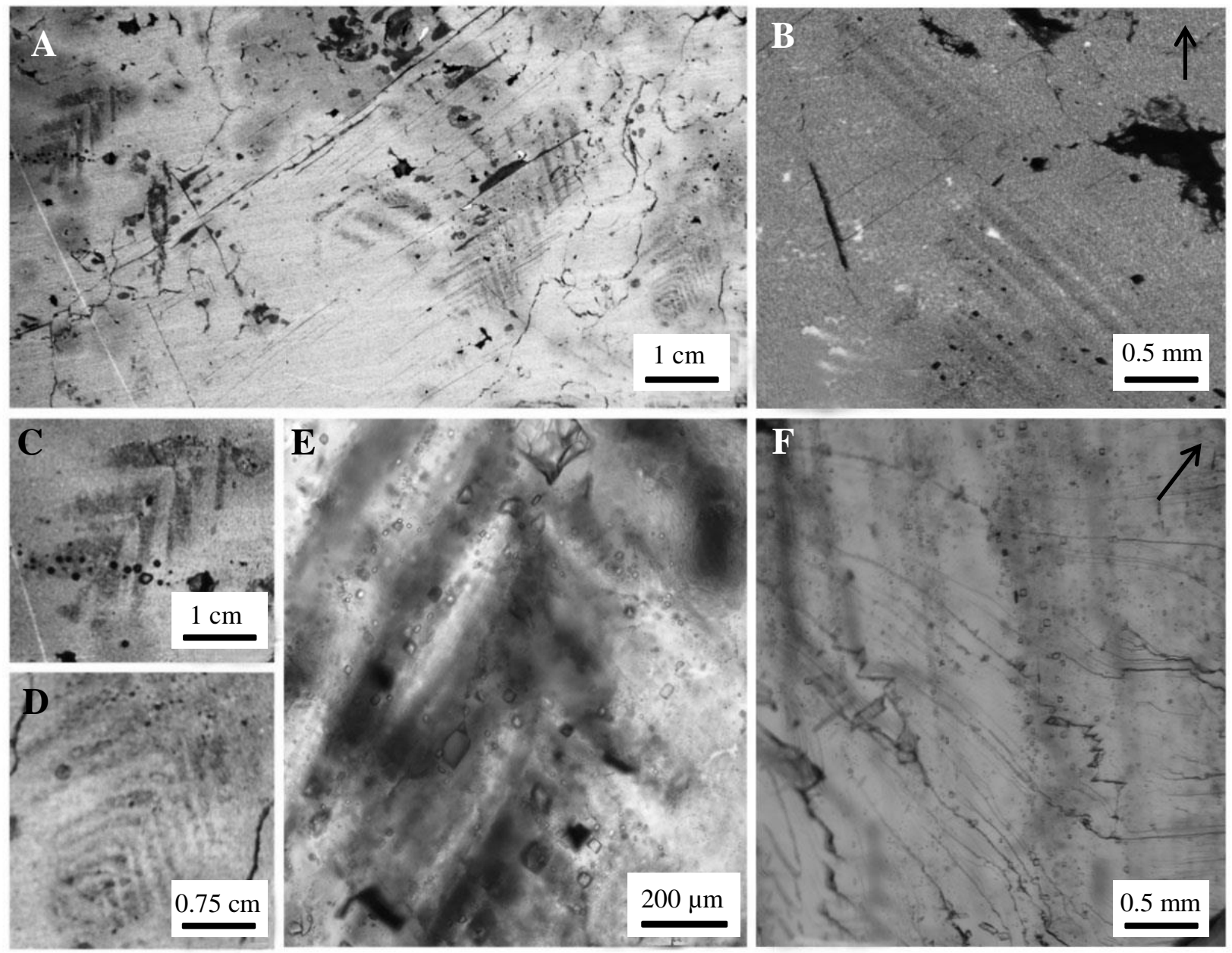

Figure 8. Photographs of chevron and cumulate halite beds at various depths in the Larne Halite Member. A) An overall view of a thin section from a halite bed at a depth of 906.1 meters. Three chevron crystals can be seen with the naked eye. Chevrons point stratigraphically up. B and F) Growth bands seen along cumulate crystals at a depth of 819.9 meters. Arrows indicate stratigraphic up. C and D) Close up views of chevrons from 906.1 meters. Chevrons point stratigraphically up. E) Growth bands in a chevron crystal found at the depth of 659.5 meters. Chevron points stratigraphically up.

These beds were selected based on observations of chevron and cumulate crystals and their potential to contain primary fluid inclusions for analyses. Due to the sensitive nature of halite, the representative chips varied in size from 0.13 centimeters to 2.1 centimeters, and $\sim 1$ 
mm thick after being polished. Descriptions of the 12 beds as they appeared in the core and under the microscope are listed below.

660.0- 659.5 meters: Halite beds at a depth of 659.5 meters consisted of chevron (Fig. 8E) and cumulate halite crystals. There was approximately 5\% mud at this depth, and it draped across the tops of halite crystals. The beds were defined by crystal size and shape, and consisted of centimeter -scale bottom- growth chevron crystals. Dissolution pipes that were later filled with clear halite could be seen cutting vertically through the halite beds. This indicates that the beds were in contact with under saturated waters at some point during their deposition.

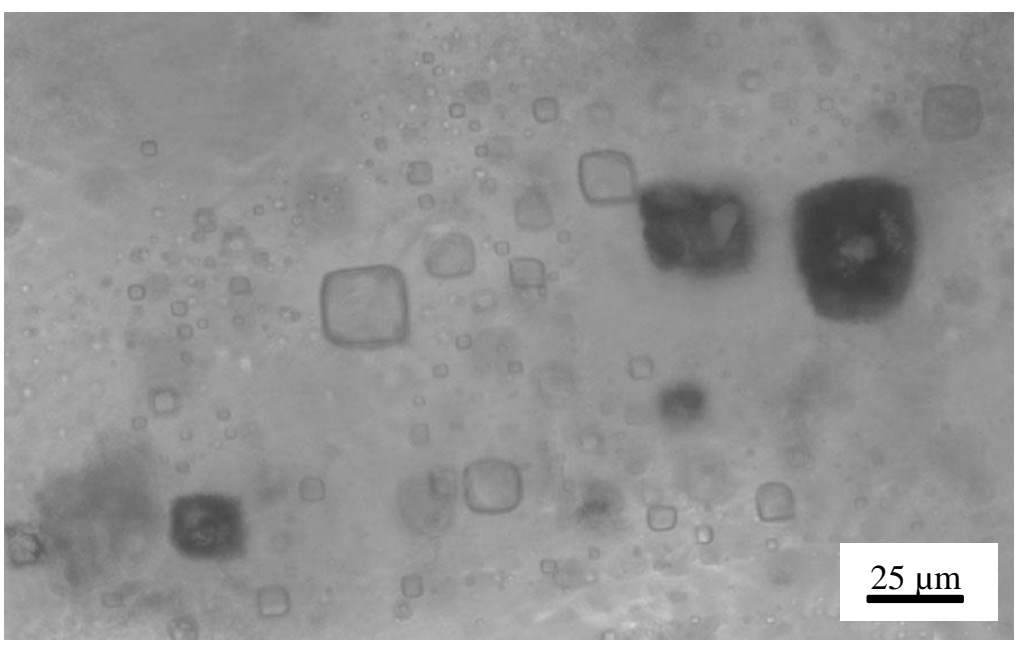

Figure 9. Primary fluid inclusions along a growth band in a chevron crystal at a depth of 659.5 meters showing a subcubic to cubic shape.

Two chevron and four cumulate crystals were studied from this depth, each showing primary fluid inclusions. Each chip contained some areas of iron oxide rich mud, which caused some petrographic difficulties when trying to observe the features and inclusions in those areas. However, abundant fluid inclusions were still able to be seen. Chevron crystals could be seen with the naked eye on the halite chips (Fig. 8A, C, and D). Hundreds of primary inclusions were found in all chips, with varying large $(\sim 50 \mu \mathrm{m})$ and small $(\sim 1 \mu \mathrm{m})$ inclusions both appearing 
subcubic to cubic (Fig. 9). Inclusions were all liquid, but rare daughter crystals in fluid inclusion were also seen. Thick rims were noted along all primary inclusions, and when observed with a high powered objective, the rim had a double rim appearance (Fig. 10). When observed using UV light, there were no signs of fluorescence.



Figure 10. Primary unaltered fluid inclusions in a chevron at a depth of 659.5 meters. Note the double rims (arrows) on the fluid inclusions.

768.0-766.9 meters: At a depth of 766.9 meters, bedded halite was chocolate brown in the core due to an influence of chocolate brown mud. Beds of cumulate and bottom growth crystals could be seen by changes in color and crystal shape. The crystals in these beds were relatively large (1-2 centimeters) and were lined with mud drapes, making up about 5\% of the total composition. Dissolution pipes filled with clear halite could be seen cutting vertically through the halite beds. 
Three very small cumulate halite chips were studied as representative samples for the depth of 766.9 meters. Two of the chips were approximately 0.5 centimeters in width, and the third was approximately 1 centimeter in width. Each halite chip was abundant in iron-oxide mud which accounted for $40-60 \%$ of the halite chip. In clear, mud free areas, primary fluid inclusions as well as numerous secondary inclusions were distinct and plentiful. Primary fluid inclusions were between 5 and $10 \mu \mathrm{m}$ and were all liquid inclusions with a double rim and cubic shape. Altered inclusions, isolated inclusions, and inclusions containing solids or vapor bubbles were observed, however, they were rare. Though they were rich in mud, none of the chips fluoresced under UV light.

805.5-804.8 meters: Halite beds consisted of cumulate and chevron crystals that appeared pink in the core. Chocolate brown to grey mud was also present. This depth consisted of approximately $20 \%$ mud, and had a stratigraphic change in color from brown to pink. The halite beds were defined by the crystal shape and mud drapes (Fig. 7B). Within the halite beds, dissolution pipes filled with halite can be seen cutting vertically through the halite crystals.

Beds consisted of halite crystals ranging in size from 0.25 centimeters to 0.5 centimeters. Small fractures and areas of dissolution could be seen on the surface of the crystals, but fluid inclusions remained intact. Primary fluid inclusion sizes were fairly consistent, with sizes ranging between 10 and $15 \mu \mathrm{m}$. FIAs were all liquid, thick double rimmed primary fluid inclusions that had negative crystal shapes. Rare accidental daughter crystals could be seen in 2 primary inclusions, but no fluorescence under UV light could be seen. Secondary fluid inclusions were significantly more abundant in these crystals than in the previous two depths. Secondary inclusions could be seen cutting across the crystals and growth bands, and along fractures in the 
crystals. In one of the halite chips, a random isolated fluid inclusion could be seen, but no other isolated inclusions were observed in any of the other crystals.

807.0-805.6 meters: This depth consisted of $\sim 3 \mathrm{~cm}$ tall chevron and $\sim 3.5 \mathrm{~mm}$ wide cumulate halite crystals, and $\sim 20 \%$ mud. Beds at this depth also show vertical, halite-filled dissolution pipes cutting vertically through them.

Small chevron and cumulate halite crystals between 0.7 and 0.9 centimeters were analyzed at this depth. Each chip contained only small amounts of mud (5-10\%), which allowed for better fluid inclusion observations than at 766.9 meters. Approximately $90 \%$ of inclusions were primary, all liquid inclusions with double rims, and a perfect negative crystal shape. Primary inclusions ranged in size from $\sim 5-15 \mu \mathrm{m}$. Approximately $5 \%$ of primary fluid inclusions contained accidental daughter crystals. Isolated inclusions were also noted at this depth (Fig. 11). There was no fluorescence under UV light.


Figure 11. Photographs of two isolated fluid inclusions within the Larne Halite at a depth of 805.6 meters. Isolated inclusions are irregularly shaped and commonly contained vapor bubbles. 
817.5-815.5 meters: Pink to brown colored cumulate halite crystals are seen in the core. Clear bedding is defined by the cubic shape of the halite crystals and a slight variation in the halite color. Dissolution pipes filled with clear halite cross cut halite crystals.

Four cumulate halite crystals were analyzed, and ranged in size from 0.5-0.8 centimeters in width. The iron-oxide mud content for each chip was about 5-10\%, which caused very little obstruction in viewing the fluid inclusions of each crystal. Like the beds before it, this depth contained mainly primary, all liquid inclusions with double rims, and rare isolated inclusions with vapor bubbles.

The primary fluid inclusion sizes were smaller, ranging from less than $2 \mu \mathrm{m}-\sim 10 \mu \mathrm{m}$. There were also higher amounts of accidental daughter crystals in primary fluid inclusions (Fig. $12 \mathrm{C}$ ), and rare liquid-solid-vapor inclusions (Fig. $12 \mathrm{~A}$ and B) than had previously been seen. Each chip contained at least two daughter crystals within primary fluid inclusions.


Figure 12. Photographs of daughter crystals in fluid inclusions in the Larne Halite Member at a depth of 815.5 meters. A) A rare primary inclusion containing liquid, vapor and a daughter crystal. The beds at this depth are one of the only place where liquid-solid-vapor inclusions were found. B) A liquid-solid-vapor inclusion that shows the double rim. C) Photograph of a typical liquid-solid inclusion. Notice that multiple solids are encompassed within the inclusion. 
Two of the four chips contained isolated liquid-solid-vapor inclusions. Some blue fluorescence was seen in the mud of two of the halite chips. However, only one chip showed fluorescence within a daughter crystal

820.1-819.6 meters: Halite beds at a depth of 819.6 meters contain chevron and cumulate halite crystals that are clear-brown in color. The bedding is well defined and is outlined by mud drapes. The halite crystals are approximately 1-1.5 centimeters in size and contain dissolution pipes filled with clear halite.

Cumulate and chevron crystals from these beds were similar to those at 815.5 meters. Mud was very rare in these crystals $(<5 \%)$, and fluid inclusions, though small (generally $2-5 \mu \mathrm{m})$ were easily visible. Primary, secondary, and isolated inclusions exist in the halite crystals. The majority of inclusions were primary. Approximately $90 \%$ of all primary inclusions were all liquid inclusions with double rims that grew along distinct growth bands. Similarly, to 815.5 meters, there were many liquid-solid and some liquid-solid-vapor inclusions found at this depth. However, at this depth, there was blue fluorescence in the mud of each of the halite chips, and blue and yellow fluorescence of inclusion liquid in two of the halite chips.

842.1-841.5 meters: Halite beds containing cumulate and chevron crystals were noted at this depth. Beds were defined by the alternating halite color and the mud drapes defining bedding ( $\sim 5 \%)$. Dissolution pipes filled with clear halite are seen cutting across halite beds, and areas of definite bottom growth crystals are seen.

Relatively large chevron and cumulate halite crystals (0.9-2.1 centimeters in size) that were rich in iron oxide mud ( $25-40 \%)$ were analyzed. Though the chips were relatively large, the abundance of mud made it difficult to locate and observe fluid inclusions. However, in areas 
that were clear to cloudy, primary fluid inclusions were abundant. Rare secondary, breached, and isolated inclusions containing vapor bubbles were noted, but were not as common as they were at 815.5 and 819.6 meters. Primary fluid inclusions were mainly all liquid with double rims, but approximately $2-5 \%$ of all primary inclusions contained both liquids and solids (Fig.13). Unlike the shallower depths of 815.5 and 819.6 meters, fluid inclusions at this depth were generally significantly larger, with some inclusions as large as 25-35 $\mu \mathrm{m}$. Under UV light, blue and yellow fluorescence can be seen in the muddy areas of the crystals, but not in the inclusions themselves.

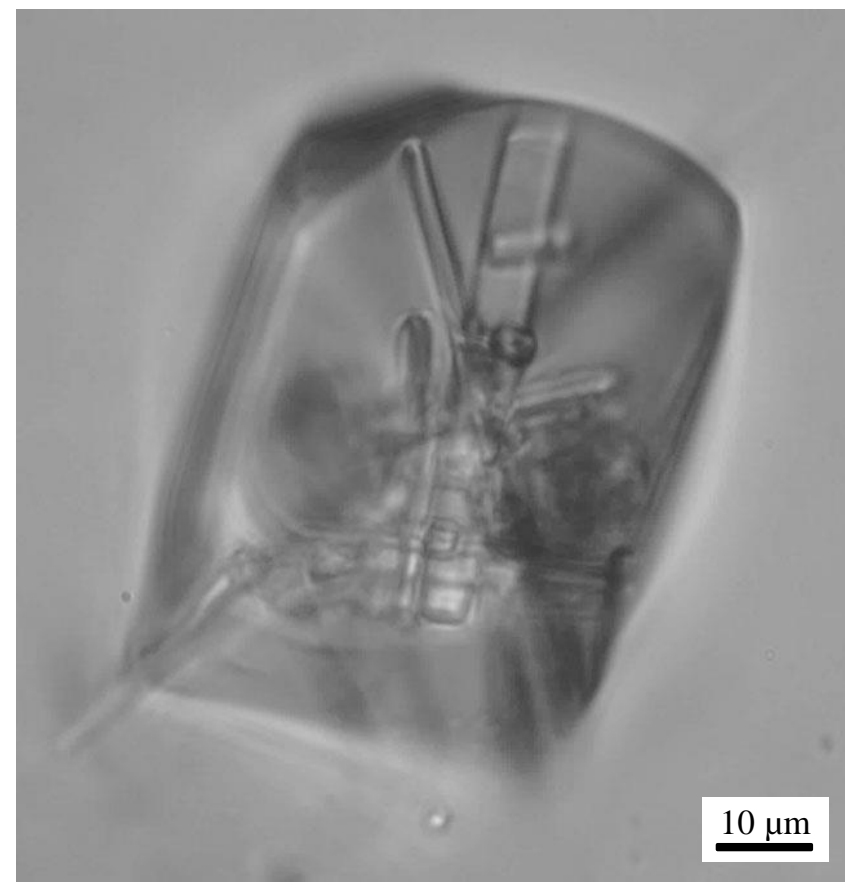

Figure 13. A fluid inclusion at a depth of 841.5 meters showing an abundance of solids.

864.0-862.4 meters: Halite beds with $\sim 5 \%$ mud were found at this depth. Halite crystals were chevrons, ranging from 1-3 centimeters in size, showing distinct upward growth textures, and alternating beds of mud, and halite. Dissolution pits filled with clear halite were also seen. 
Though iron oxide mud was rare in the cumulate halite chips from this depth $(<5 \%)$, it was still difficult to locate fluid inclusions. Fluid inclusions were less abundant at this depth than any of the other depths observed. The majority (95\%) of all inclusions were primary, all liquid inclusions with double rims. Primary inclusions that contain accidental daughter crystals were less common ( $4 \%$ of all inclusions). Rare ( $\sim 1 \%$ of all inclusions) isolated inclusions with vapor bubbles were found in one of the halite chips, but not in any of the other three chips. There were also signs of some alterations to primary fluid inclusions in one of the chips, showing stretching of several inclusions. Two of the four halite chips showed no sign of fluorescence under UV light, but the other two chips showed a blue fluorescence in the mud, but not in the fluid inclusions.

887.7-887.0 meters: Bedded halite contained chevrons that were seen by the naked eye. Bedding was easily defined by mud drapes and changes in the color of the halite.

Cumulate and chevron halite crystals were 0.3-0.6 centimeters in size and contained fluid inclusions that varied greatly in size with some as small as $5 \mu \mathrm{m}$, and others as large as $\sim 45 \mu \mathrm{m}$. Fluid inclusions were predominately primary inclusions that were all liquid ( $85-90 \%)$ and liquidsolid inclusions (10-15\%), and had double rims. No secondary or isolated inclusions were seen. Few inclusions with accidental daughter crystals did display a green and blue fluorescence under UV light. However, no other fluorescence was noted in the crystals.

906.6-906.1 meters: Halite beds consisting of chevron and cumulate crystals were seen. The crystal beds were defined by rare mud drapes that outline the otherwise difficult to see halite beds. No signs of dissolution were noted in these beds. 
One cumulate and two chevron halite crystals with low mud content $(\sim 5 \%)$ ranging in size from 0.13-0.4 centimeters were representative of the halite beds occurring at a depth of 906.1 meters. Bedded halite crystals had obvious and abundant primary fluid inclusions varying in sizes from $\sim 4 \mu \mathrm{m}$ to $\sim 10 \mu \mathrm{m}$. These inclusions were mostly primary, all liquid inclusions with double rims and few contained accidental daughter crystals (Fig. 14). Secondary inclusions were also present in the crystals and were easily noted by their "S" shaped pattern cutting across growth bands within the crystal. None of the inclusions or their solids fluoresced under UV light.

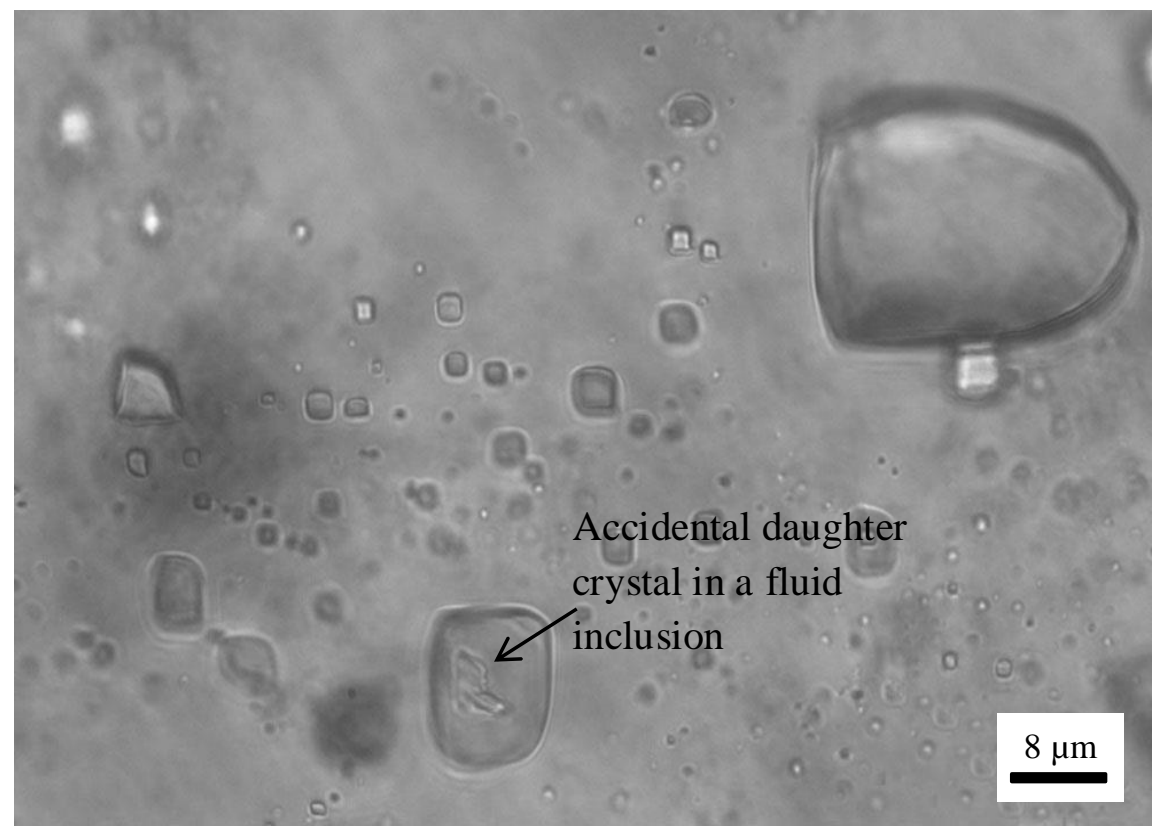

Figure 14. A growth band from the depth of 906.1 meters. Most of these primary fluid inclusions are all liquid with a double rim. Inclusion containing both liquid and daughter crystals is shown.

919.6-919.1 meters: Beds of clear, brown, and pink halite in the core contained chevron and cumulate crystals. Halite crystals were relatively large, ranging from $~ 1-1.5$ centimeters. Bedding was made evident based on color change and mud drapes outlining the beds. No signs of dissolution could be seen at this scale. 
Easily identifiable primary fluid inclusion growth bands were found in all five halite chips (three chevron and two cumulate crystals). Halite chips were low in iron oxide mud content $(<5 \%)$, which allowed for optimal viewing of growth bands and FIAs. In general, the fluid inclusions were small, averaging about 3 to $5 \mu \mathrm{m}$, but inclusions as large as $\sim 10 \mu \mathrm{m}$ were also seen. As was seen in previous depths, the majority of the primary fluid inclusions along growth bands were all liquid with double rims. Rare primary liquid-solid and isolated inclusions with vapor bubbles were seen in one of the five halite chips. A small amount of green fluorescence appeared in the mud of one halite chip under UV light, but no fluorescence was seen in any of the inclusions.

939.0-938.4 meters: Pink to brown halite beds containing cumulate crystals ranging in size from 0.2 to 0.5 centimeters were noted at this depth. Beds were distinguished by a color change and by rare mud drapes.

Primary fluid inclusions were not as abundant as they were in shallower beds. Primary fluid inclusions that could be seen were very small, usually less than $\sim 5 \mu \mathrm{m}$, but did display the usual characteristics seen in previous beds (all liquid inclusions with double rims). Liquid- solid and isolated inclusions were rare, with only two daughter crystals and two isolated inclusions with vapor bubbles being seen. Seventy-five percent of the halite chips showed blue fluorescence in the mud under UV light, but no fluorescence was seen within inclusions.

\section{UV-vis Fluorescence}

Approximately 60 fluid inclusions in each of the twelve beds were observed with UV light at 600x magnification. Fluorescence under UV light was rare for the inclusions analyzed. Of the beds that were observed, only three of the beds showed any illumination of the fluid 
inclusions within the crystals. Beds showing fluorescence within fluid inclusions occurred at depths of $815.5,819.6$, and 887.0 meters.

Blue, yellow, and yellow/green fluorescence was seen at depths of 815.5 and 819.6 meters in the liquid of the fluid inclusions, but blue and green fluorescence at a depth of 887.0 meters could only be noted in the daughter crystals (Fig. 15). The blue fluorescence was seen in spherical to elliptical shaped solids that were approximately 5-10 microns in size. The yellow fluorescence was found only in the liquid of fluid inclusions. The yellow/green fluorescence occurred in circular solids approximately 2-3 microns in size. Though these depths did show illumination, it did not occur in every inclusion, or every solid that was observed.
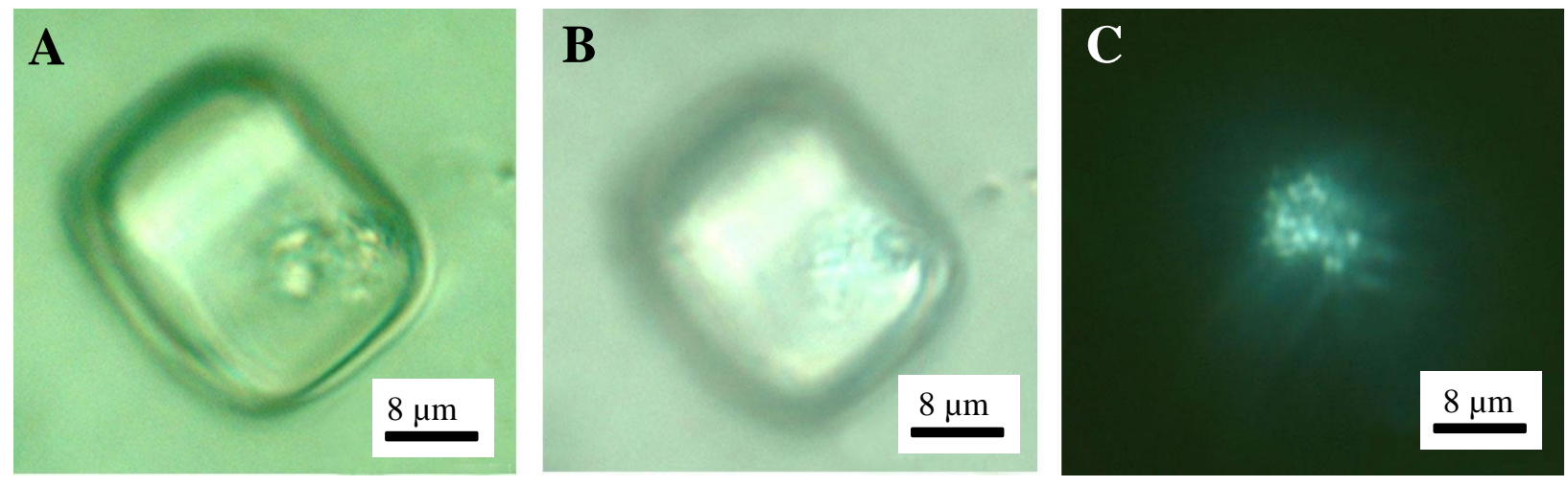

Figure 15. Primary fluid inclusion observed in a bed at a depth of 887.0 meters. A) Fluid inclusion containing solids and liquids viewed in PPL. B) The same fluid inclusion viewed in a combination of PPL and UV light. The focus is at a slightly different depth than A and C. Note the slight blue fluorescence. C) The same fluid inclusion viewed under UV light.

\section{Freezing-Melting Microthermometry}

Freezing-melting microthermometry was attempted for 36 primary fluid inclusions from the twelve different beds. Fluid inclusions were placed in a Fluid, Inc. U.S.G.S. modified-gas flow heating/cooling stage and were cooled to $-190^{\circ} \mathrm{C}$. After cooling to $-190^{\circ} \mathrm{C}$, no visible changes to the inclusions were seen. 
All 36 fluid inclusions from the Larne Halite failed to freeze. Therefore, no data could be obtained about phases present during warming. Modern halite samples from Western Australia and alkaline saline Searles Lake in California, and ancient halite samples from the Nippewalla Group of Kansas were also cooled, and successfully froze.

\section{Laser Raman Spectroscopy}

Laser Raman spectroscopy was conducted on the liquid phase of 60 primary fluid inclusions from 12 beds. Forty-five inclusions yielded Raman spectra. Fifteen small inclusions $(\sim 1 \mu \mathrm{m})$ did not. This was likely due to the difficulty in focusing the laser on the liquid phase of these fluid inclusions due to their small size. Spectra with water peaks indicated that the laser was focused on the liquid phase of the inclusion. Halite beds at depths of $695.5,805.6,815.5$, 819.6, 841.5, 862.4, 887.0, 906.1, 919.1, and 938.4 meters were successfully analyzed. Samples from the depths of 766.9 and 804.8 meters were analyzed, but yielded poor results because spectra lacked water peaks. All fluid inclusions from the depths of 766.9 and 804.8 meters were smaller than 5-10 microns. This made focusing the laser on individual inclusions challenging. Therefore, no laser Raman data is reported at these depths. Samples were first analyzed at $11 \%$ laser power capacity when the laser was failing and later at $100 \%$ power capacity when the laser was new. Analyses were performed on 12 of the specific inclusions at both $11 \%$ and $100 \%$. The only minor difference between these spectra was that a small peak at $\sim 1550 \mathrm{~cm}^{-1}$, on the shoulder of the water peak appeared when the laser was at $100 \%$ power, but was absent at $11 \%$ laser power.

A detailed catalog of peak spectral locations can be found in appendix E. Table 2 summarizes relevant Raman peaks detected in liquid phases of primary fluid inclusions from each halite bed. 
Table 2. Table summarizing Raman peaks for analysis of liquid in primary fluid inclusions in 12 beds of halite from the Larne Halite Member. Peaks at $422 \mathrm{~cm}^{-1}$ indicate bisulfate. Peaks at 490 $\mathrm{cm}^{-1}$ are characteristic of aluminum sulfate species, such hydronium alunite. Any peaks at 1054 $\mathrm{cm}^{-1}$ would indicate bisulfate in a solution with $\mathrm{pH}$ less than 1 . The presence of each species is indicated by an " $\mathrm{x}$ " in the table.

\begin{tabular}{|c|c|c|c|c|}
\hline Depth $(\mathrm{m})$ & $\begin{array}{c}422 \mathrm{~cm}^{-1} \\
\text { peak }\end{array}$ & $\begin{array}{c}490 \mathrm{~cm}^{-1} \\
\text { peak }\end{array}$ & $\begin{array}{c}1054 \mathrm{~cm}^{-} \\
\text {peak }\end{array}$ & $\begin{array}{c}\sim 1640 \mathrm{~cm}^{-1} \text { water } \\
\text { peak }\end{array}$ \\
\hline 659.5 & - & $\mathrm{x}$ & - & $\mathrm{x}$ \\
\hline 766.9 & - & - & - & - \\
\hline 804.8 & - & - & - & - \\
\hline 805.6 & - & $\mathrm{x}$ & - & $\mathrm{x}$ \\
\hline 815.5 & $\mathrm{x}$ & $\mathrm{x}$ & - & $\mathrm{x}$ \\
\hline 819.6 & - & $\mathrm{x}$ & - & $\mathrm{X}$ \\
\hline 841.5 & - & $\mathrm{x}$ & - & $\mathrm{X}$ \\
\hline 862.4 & $\mathrm{x}$ & - & - & $\mathrm{X}$ \\
\hline 887.0 & $\mathrm{x}$ & $\mathrm{x}$ & - & $\mathrm{X}$ \\
\hline 906.1 & - & $\mathrm{x}$ & - & $\mathrm{x}$ \\
\hline 919.1 & $\mathrm{x}$ & $\mathrm{x}$ & - & $\mathrm{x}$ \\
\hline 938.4 & $\mathrm{x}$ & $\mathrm{x}$ & - & \\
\hline
\end{tabular}

660-659.5 meters: The fluid inclusions all displayed water peaks at $\sim 3400$ and $\sim 1640$ $\mathrm{cm}^{-1}$. Other notable peaks were seen at $\sim 1017$ and/ or $1020, \sim 984$, and $\sim 489-490 \mathrm{~cm}^{-1}$. Furthermore, a broad peak from $\sim 1060-1200$ was seen, and peaks in the 600 range of approximately 600,630, and $665 \mathrm{~cm}^{-1}$ were observed. Another broad peak from $\sim 325-370 \mathrm{~cm}^{-1}$ as well as peaks at 230 and $236 \mathrm{~cm}^{-1}$ were detected in these beds.

807-805.6 meters: Fluid inclusions displayed similar Raman spectra to those at a depth of 659.5 meters. A broad water peak exists at $\sim 3400$ and $\sim 1640 \mathrm{~cm}^{-1}$. Peaks at $\sim 1017$ and/ 1020, and peaks at $\sim 630$ and $\sim 490 \mathrm{~cm}^{-1}$ were distinct at this depth. Sulfate peaks at $\sim 982 \mathrm{~cm}^{-1}$ were present, but subtle.

817.5-815.5 meters: Water peaks at $\sim 3400$ and $1640 \mathrm{~cm}^{-1}$ were seen. Peaks at $\sim 1017$ and/or 1020, $\sim 490$, and $\sim 421 \mathrm{~cm}^{-1}$ were easily distinguished. Other notable peaks occurred at $\sim 1117$ and $\sim 1131 \mathrm{~cm}^{-1}, \sim 610, \sim 631$, and $\sim 679 \mathrm{~cm}^{-1}$, and $\sim 450$ and $\sim 499 \mathrm{~cm}^{-1}$. 
820.1-819.6 meters: The fluid inclusions at this depth were slightly different than those that were previously mentioned. Water peaks at $\sim 3400$ and $\sim 1640 \mathrm{~cm}^{-1}$ were observed. Few sharp, distinct peaks could be seen. A peak at $\sim 1317$ and $\sim 41 \mathrm{~cm}^{-1}$ were easily identifiable, but other noted peaks were small and weaker. These smaller peaks occurred at approximately 1102 , $690,670,640,517,502,245,224$, and $190 \mathrm{~cm}^{-1}$.

842.1-841.5 meters: Peaks indicating water were seen at $\sim 3400$ and $\sim 1640 \mathrm{~cm}^{-1}$ and strong peaks at $\sim 1020, \sim 503$, and $\sim 490 \mathrm{~cm}^{-1}$ were also seen. Weaker peaks at approximately $1162,1132,679,630,610$, and $200 \mathrm{~cm}^{-1}$ were also observed.

864.0-862.4 meters: Water peaks at $\sim 3400$ and $\sim 1640 \mathrm{~cm}^{-1}$ were seen. Other strong peaks at this depth occurred at approximately 1020, 490, 422, 250, and $230 \mathrm{~cm}^{-1}$.

887.7-887.0 meters: Water peaks were noted at $\sim 3400$ and $\sim 1640 \mathrm{~cm}^{-1}$. Other peaks are observed at approximately $1131,1020,502,490$, and $422 \mathrm{~cm}^{-1}$. Other, weaker peaks could be seen in at approximately $1039,679,630$, and $612 \mathrm{~cm}^{-1}$.

906.6-906.1 meters: The spectra were relatively noisy compared to the other spectra. This is likely due to organics being present within the inclusions that were not seen due to the moderate quality of the optics on the laser Raman. The usual water peaks appeared at $\sim 3400$ and $\sim 1640 \mathrm{~cm}^{-1}$, and a broad, distinct peak at $\sim 1321$ also appeared. Other peaks that were seen included a peak at $\sim 490 \mathrm{~cm}^{-1}$ and a peak at $\sim 420 / 421 \mathrm{~cm}^{-1}$.

919.6-919.1 meters: The depth of 919.1 meters contained water peaks at $\sim 3400$ and $\sim 1640 \mathrm{~cm}^{-1}$, and intense peaks at approximately $1020,501,490$, and $421 \mathrm{~cm}^{-1}$. Other, smaller peaks were noted at approximately 432, 237, 190,183, and $172 \mathrm{~cm}^{-1}$. 
939.0-938.4 meters: The fluid inclusions within these beds contained a fairly unique spectrum. The water peaks at $\sim 3400$ and $\sim 1640 \mathrm{~cm}^{-1}$ were apparent, but other distinct peaks were not typical of those that had been seen in previous beds. Sharp, distinct peaks occurred at approximately $1632,1438,1371,1296,1110,1064$, and $195 \mathrm{~cm}^{-1}$. Smaller, less intense peaks occurred at approximately $1243,1219,1160,939$, and $640 \mathrm{~cm}^{-1}$.

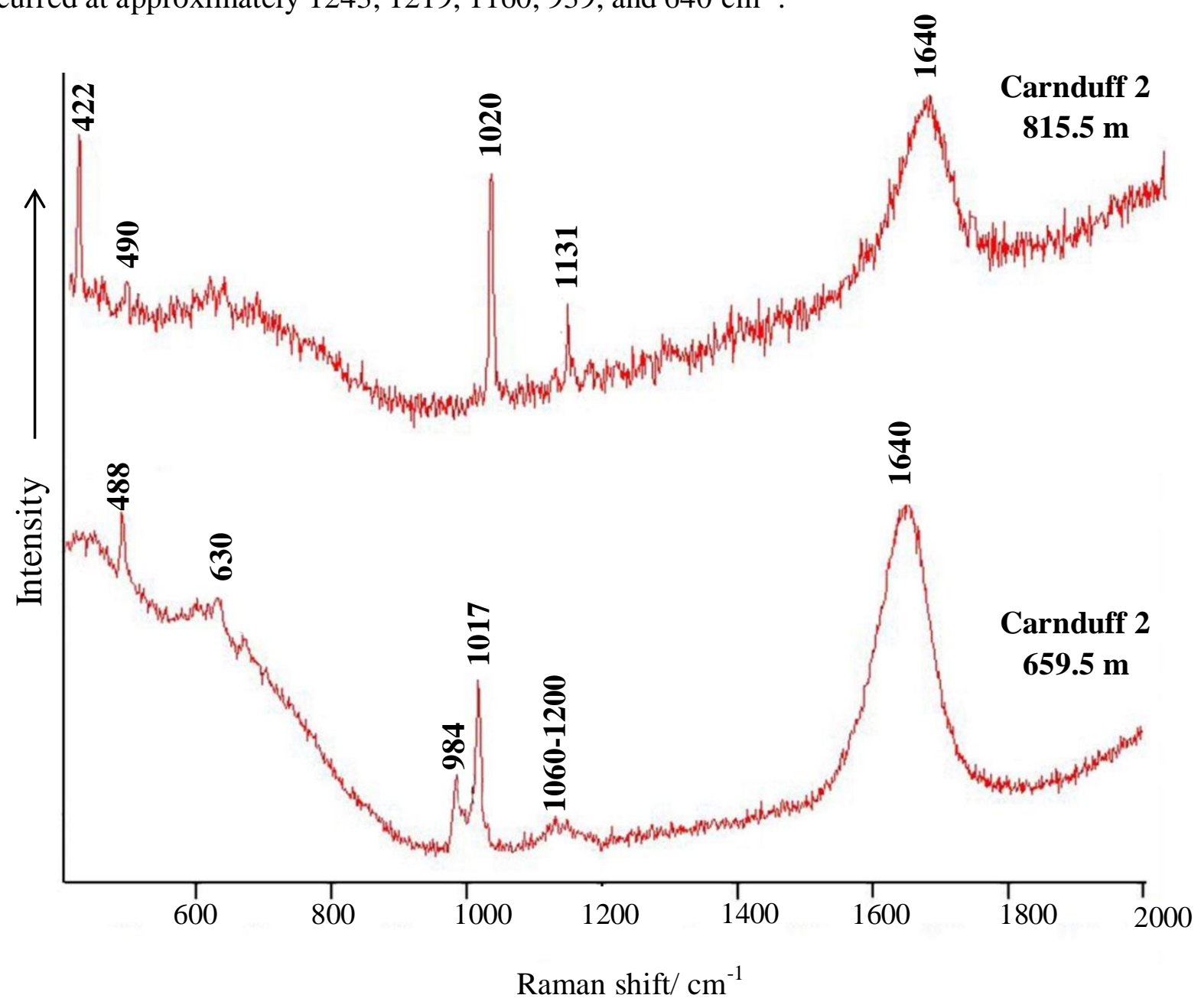

Figure 16. Representative spectra of the liquid phase of fluid inclusions in bedded halite in two beds showing dominant peaks between 900 and $1300 \mathrm{~cm}^{-1}, 600$ and $700 \mathrm{~cm}^{-1}, 488$ and $502 \mathrm{~cm}^{-1}$, and 419 and $422 \mathrm{~cm}^{-1}$.

Peaks varied slightly at different bed depths, but an overall trend was observed. Fluid inclusions at all depths showed a trend of the majority of peaks occurring between $~ 900$ and $1300 \mathrm{~cm}^{-1}, 600$ and $700 \mathrm{~cm}^{-1}, 488$ and $502 \mathrm{~cm}^{-1}$, and 419 and $422 \mathrm{~cm}^{-1}$ (Fig.16). 
Peaks ranging from $235 \mathrm{~cm}^{-1}$ to $237 \mathrm{~cm}^{-1}$ were also seen in 7 of the 12 beds analyzed. Furthermore, sharp peaks commonly appeared at wavelengths of $\sim 1017$ and $\sim 1020 \mathrm{~cm}^{-1}$ at all beds except 819.6 and 938.4 meters. To insure that none of the peaks were a result of the chemical make-up of halite, a mud and inclusion-free area of each halite chip was analyzed and no peaks were detected.

After analyzing fluid inclusions at each bed depth, waters from modern acid saline environments were analyzed using the same laser wavelength and laser intensity. These waters were from Lake Aerodrome and Gneiss Lake in Western Australia and Salar Gorbea in Chile. These modern acid brines had known $\mathrm{pH}$ values of less than two. Lake Aerodrome and Gneiss Lake had relatively simple spectra; Lake Aerodrome ( $\mathrm{pH}$ of 1.8 ) had a water peak at $\sim 1640 \mathrm{~cm}^{-1}$ and a peak at $980 \mathrm{~cm}^{-1}$ (Fig. 17), and Gneiss Lake (pH=1.4) had peaks at $\sim 1640$ and $983 \mathrm{~cm}^{-1}$. Two samples from Salar Gorbea (from a pink pool and a blue pool; $\mathrm{pH}=1.6$ and 1.8 respectively) have a more complex overall spectra with water peaks at $\sim 1640 \mathrm{~cm}^{-1}$ and peaks from approximately 1000-1200 (broad peak), 985, 880, 617, 488, and $452 \mathrm{~cm}^{-1}$, and 1060-1200 (broad peak), 980, 880, 630, 610, 489, and $452 \mathrm{~cm}^{-1}$ (Fig. 17), respectively.

Waters from previously documented acid saline inclusions in bedded halite of the Permian Opeche Shale and the Nippewalla Group (Benison et al., 1998; Fig. 18) were also analyzed for comparison to the Mercia Mudstone inclusions. A total of 24 fluid inclusions (12 from the Opeche Shale and 12 from the Nippewalla Group) were analyzed. The Opeche Shale spectra displayed peaks at $\sim 1640,1400,1053,985,730$, and $487 \mathrm{~cm}^{-1}$. The Nippewalla Group showed peaks at $\sim 1640,984,861$, and $490 \mathrm{~cm}^{-1}$. These confirm previous studies of the Nippewalla Group and Opeche Shale (Benison et al., 1998). 


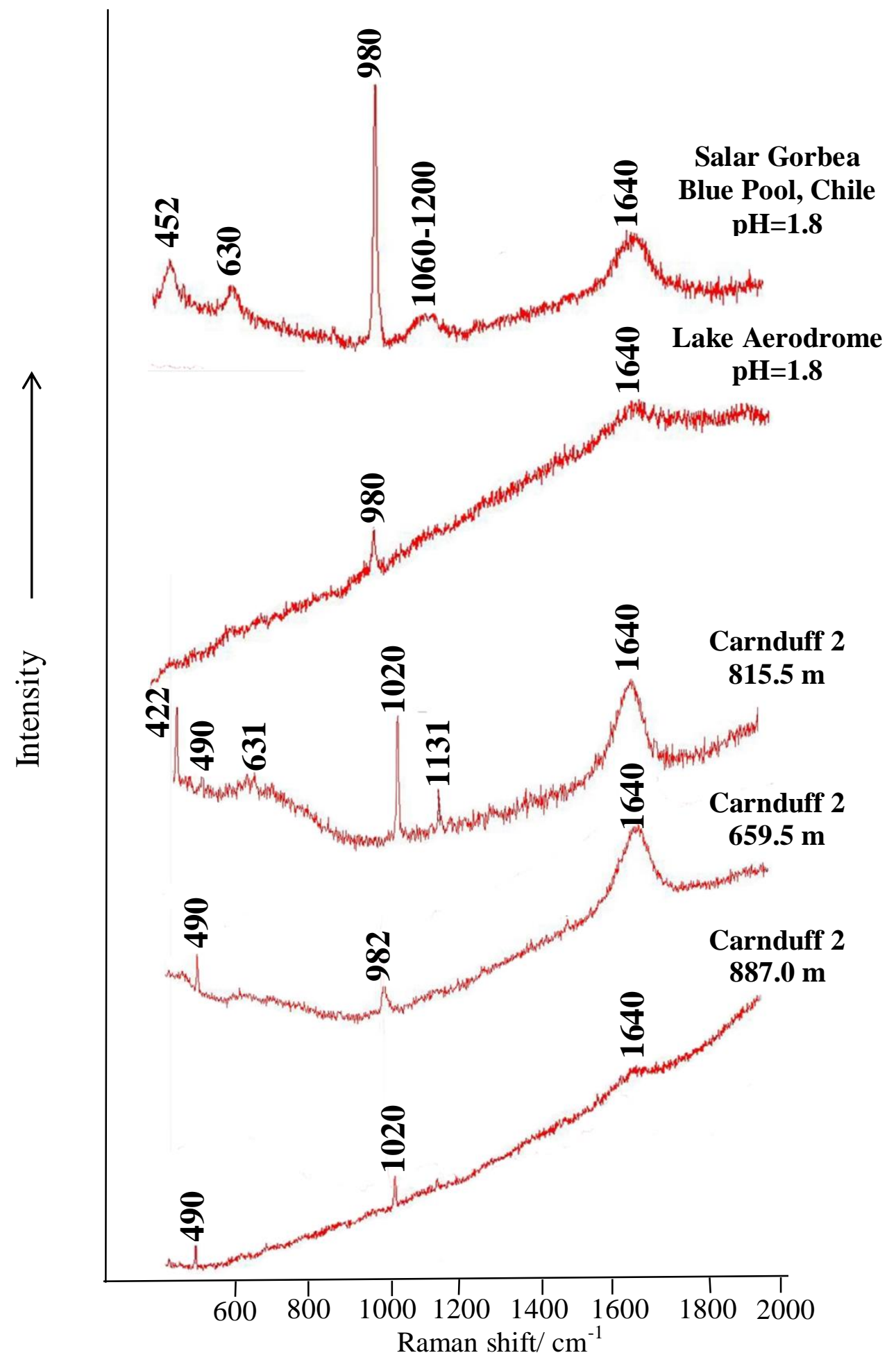

Figure 17. A comparison of Raman spectra between the three representative spectra of the liquid phase of the fluid inclusions found within the Larne Halite Member (bottom three spectra) and two modern acid saline lakes (top two spectra). Water peaks are in all samples at $1640 \mathrm{~cm}^{-1}$. Peaks at $\sim 980-982 \mathrm{~cm}^{-1}$ are sulfate. Significant peaks here are bisulfate at $\sim 422 \mathrm{~cm}^{-1}$ and aluminum sulfate compounds at $\sim 490 \mathrm{~cm}^{-1}$, which indicate acidity. Although two modern lake samples have $\mathrm{pH}$ of 1.8 , their spectra show no obvious acidity indicators. 


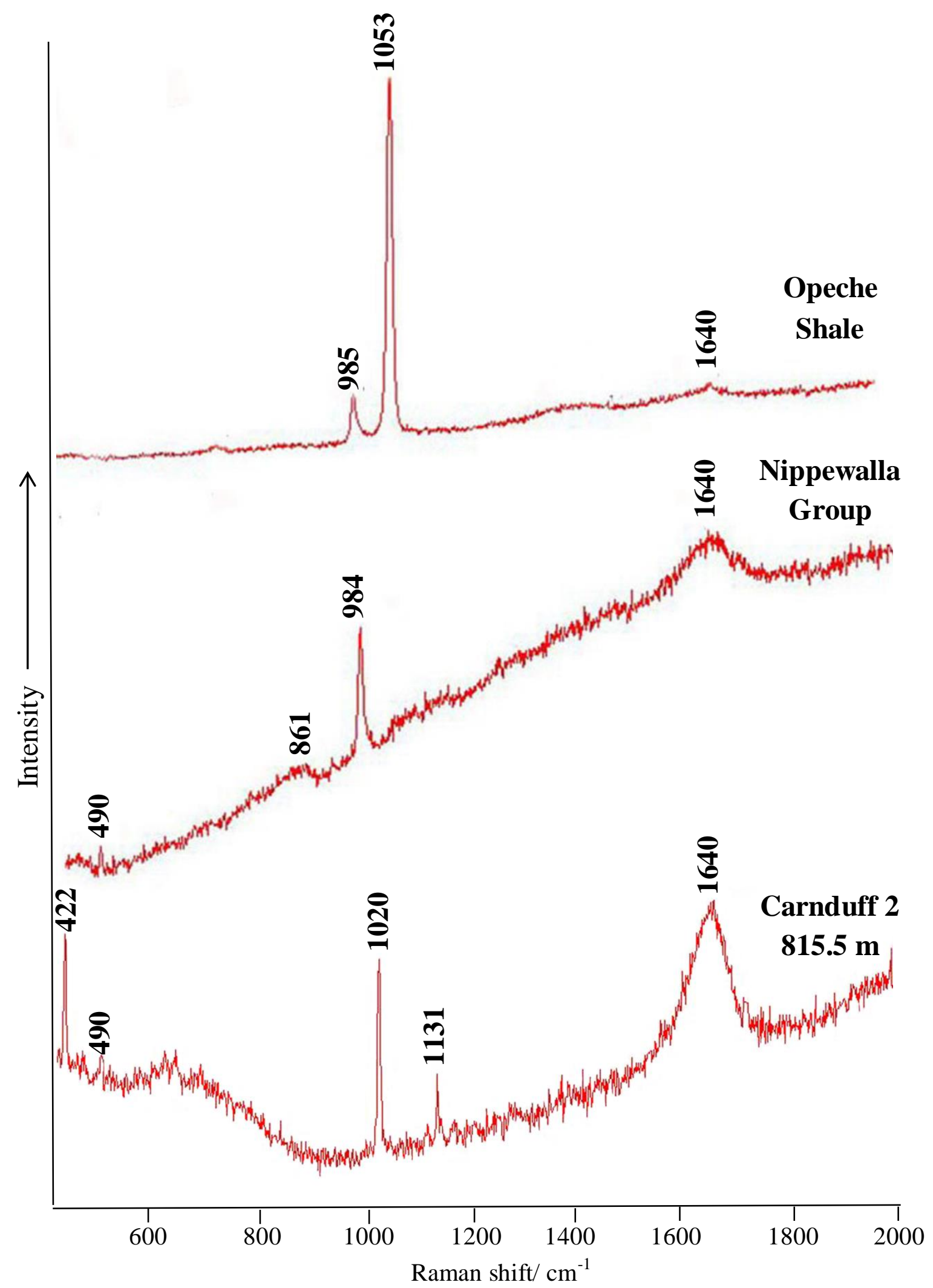

Figure 18. A comparison of the Raman spectra between the Opeche Shale, Nippewalla Group, and Larne Halite show sulfate peaks in the range of 861 to $1020 \mathrm{~cm}^{-1}$, a peak at approximately $490 \mathrm{~cm}^{-1}$ indicates aluminum sulfate complexes, and bisulfate peaks at $\sim 1054 \mathrm{~cm}^{-1}$ (Opeche Shale) and $\sim 22 \mathrm{~cm}^{-1}$ (Carnduff 2). 


\section{Laser Raman spectroscopy of accidental daughter crystals in fluid inclusions}

Solids were noted within some fluid inclusions, and most appeared as elongated, needlelike or bladed minerals that were accidentally trapped as the halite grew. When analyzed with the laser spectrometer, they yielded spectra indicating that they were sulfate minerals. Such sulfate minerals included anhydrite and gypsum (Fig. 19).

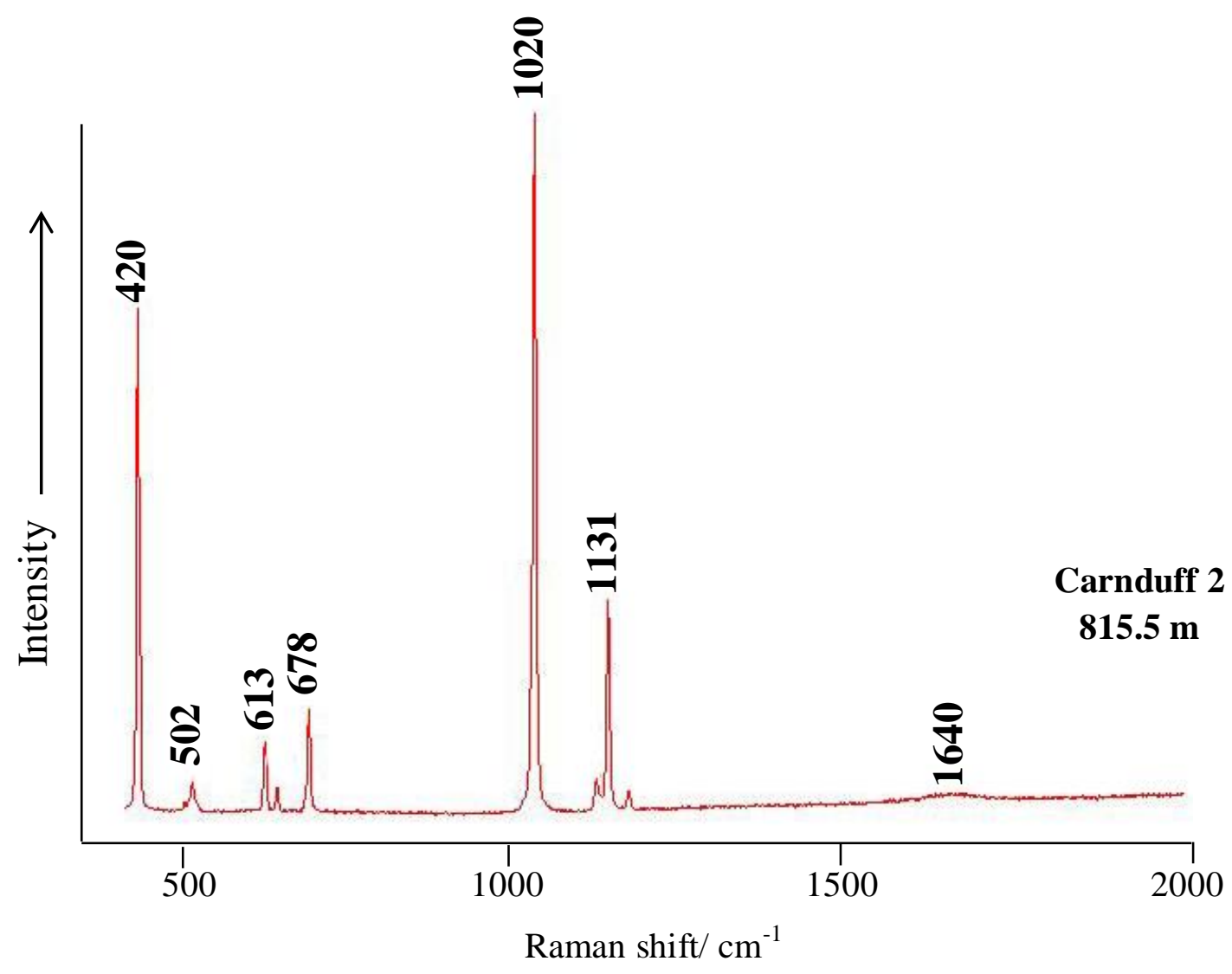

Figure 19. Raman spectra of a solid within a fluid inclusion at 815.5 meters. This spectrum is indicative of solid anhydrite.

\section{Interpretations}

\section{Fluid inclusion Petrography}

Chevron and cumulate crystals within the Carnduff 2 core can be seen both with the naked eye and under the microscope. Cumulate crystals are crystals that form in the water 
column or at the air-water interface, and can grow together; forming rafts (Lowenstein and Hardie, 1985). Once the crystals or rafts become heavy enough to sink, they settle to the bottom of the surface water. These cumulate crystals can then act as a nucleus for chevron crystal growth. Cumulate crystals can form in saline surface waters of any depth. However, chevron crystals that form at the sediment-water interface only form in shallow waters, suggesting that the Larne Halite lake waters were less than half a meter deep (Arthurton, 1973; Benison et al., 2007; Lowenstein and Hardie, 1985; Schubert et al., 2010a).

Chevron crystals were found in 10 of the 12 beds investigated, indicating that most of the beds studied formed in shallow waters. Beds at the depths of 817.5-815.5 and 939.0-938.4 meters contained only cumulate halite crystals. Crystals at these depths were cubic in shape and contained alternating cloudy, inclusion-rich and clear, inclusion-free growth bands. No indications of chevron crystals, such as crystals growing upward from the sediment-water interface were seen.

The fluid inclusions within the chevron and cumulate crystals consist of abundant primary fluid inclusions. This suggests that waters were trapped during the time of crystal formation (Benison and Goldstein, 1999; Goldstein, 2003; Goldstein and Reynolds, 1994). Because of this, only the primary fluid inclusions were suitable to use as paleoenvironmental indicators, because they are representative of parent surface waters.

Evidence for flooding and evapoconcentation were also interpreted by petrographic observations. In particular, most, chevron and cumulate crystals were truncated by pits and pipes that were filled with clear halite, suggesting flooding by dilute water followed by more evapoconcentration. (Benison et al., 2007; Casas and Lowenstein, 1989; Jagniecki and Benison, 2010; Lowenstein et al., 1998; Lowenstein and Hardie, 1985). No evidence of desiccation was 
observed. Efflorescent halite crusts interbedded with chevron and cumulate halite beds would be suggestive that lakes dried up. No efflorescent crusts were observed in the core. Therefore, petrography shows that bedded halite formed in shallow saline waters that underwent some evapoconcentration and flooding, but no desiccation.

Fluid inclusions were primarily all liquid inclusions. No vapor bubbles were seen in primary fluid inclusions. The lack of vapor bubbles in primary fluid inclusions indicated that the halite beds formed at typical surface temperatures (below $\sim 0^{\circ} \mathrm{C}$; Zambito and Benison, 2013), were subsequently buried shallow enough to escape stretching, and that no outgassing was occurring in the depositional environment (Benison, 2013; Benison et al., 2015).

Some primary inclusions were liquid-solid inclusions. Numerous elongated, needle-like and bladed daughter crystals were noted in the primary fluid inclusions of each bed. Most daughter crystals were identified as anhydrite based on laser Raman spectra. This shows that the lake waters during the Larne Halite deposition were $\mathrm{Na}-\mathrm{Cl}-\mathrm{Ca}-\mathrm{SO}_{4}$ rich.

Other solids within fluid inclusions appeared as rounded, slightly dimpled, pale yellow inclusions that were approximately 10 microns in size and fluoresced blue. These are interpreted as Dunaliella algae, due to their similarities in size and morphology with Dunaliella algae identified in other fluid inclusions and brines (Conner and Benison, 2013; Lowenstein et al., 2011). Because there was not any evidence of pink or orange fluorescence that is typically associated with modern Dunaliella (Conner and Benison 2013; Lowenstein et al, 2011; Schubert et al., 2009a), it is possible that the beta-carotene has decayed over time. Small (2-3 micron), spherical solids fluoresced both blue and green under UV light. These small, blue and green fluorescing solids are interpreted as prokaryotes (Conner and Benison, 2013; Schubert et al., 2009a). Additionally, 2-3 $\mu \mathrm{m}$, irregular shaped clear-pale orange solids were seen. 
One of the most notable observations found in all primary inclusions was a double rim that surrounded each inclusion (Fig. 20). This type of rim is rare in fluid inluclusions. It has only been previously noticed at or near room temperature in other acid inclusions, such as the Opeche Shale (Benison, 2013).

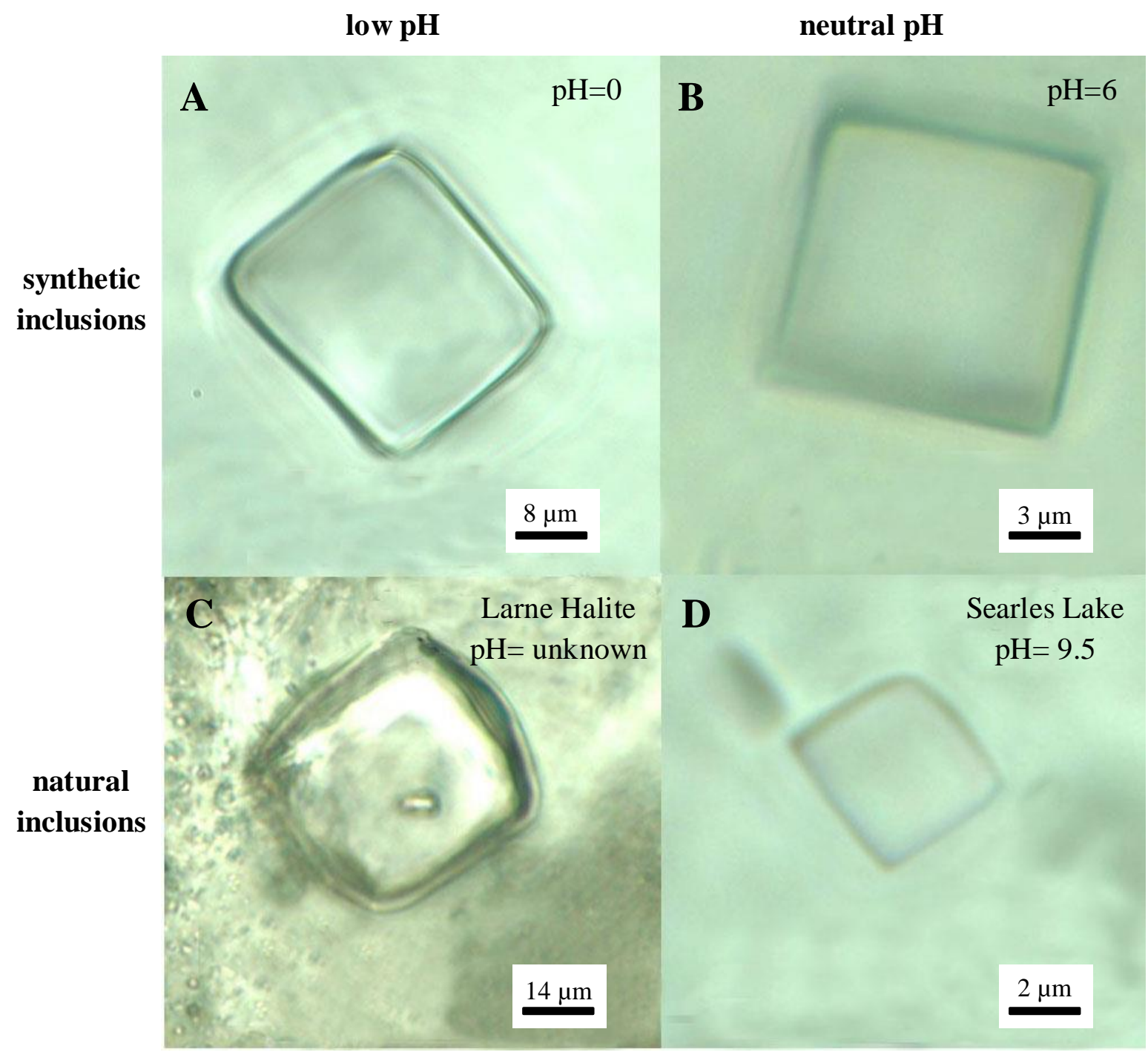

Figure 20. Double rims can be seen on both synthetic and natural fluid inclusions that form in environments with low $\mathrm{pH}$ values (left-hand column). Double rims were not seen in synthetic or natural fluid inclusions that had a neutral $\mathrm{pH}$. A) An image of a synthetic primary inclusion with a $\mathrm{pH}$ of 0 showing a double rim. B) A synthetic fluid inclusion with a $\mathrm{pH}$ of 6 lacking the double rim. C) A natural water fluid inclusion of an unknown $\mathrm{pH}$ from the Larne Halite showing a distinct double rim. D) A natural water fluid inclusion with a $\mathrm{pH}$ of 9.5 lacking a double rim. 
To further investigate the double rim in the Larne Halite inclusions, both synthetic and natural halite fluid inclusions with known low and neutral to high $\mathrm{pH}$ values were observed. Synthetic halite grown from a NaCl- $\mathrm{NaSO}_{4}-\mathrm{H}_{2} \mathrm{SO}_{4}-\mathrm{H}_{2} \mathrm{O}$ solution with a $\mathrm{pH}$ of 0 displayed the same noted double rims on its fluid inclusions. However, synthetic halite inclusions with a $\mathrm{pH}$ of approximately 6 and natural fluid inclusions from modern Searles Lake, California $(\mathrm{pH}=9.5)$ and Silurian Salina Formation halite, lacked the double rim (Fig. 20). Therefore, the double rim seems to be restricted to acid inclusions.

One possible explanation for the double rim is a reaction between the liquid and host halite. A possible reaction may be the $\mathrm{H}^{+}$in acid fluid inclusions reacting with the host halite $(\mathrm{NaCl})$ to form a rim of $\mathrm{HCl}$ (Jagniecki and Benison, 2010; Benison, personal communication). An alternative explanation may be optical distortion, perhaps caused by the high density of inclusion liquid enhancing refraction of light at inclusion-host boundaries.

Fluorescence in response to UV-vis light was noted in halite beds from various bed depths. However, the majority of the fluorescence was noted in the muddy areas of the halite chips. This may be due to the higher amounts of organic matter found within the mud than in the halite. Rare fluorescence within fluid inclusions occurred at bed depths of 815.5, 819.6, and 887.0 meters. Blue was the main fluorescence color (Fig. 21), which is suggestive of algae (Benison and Karmanocky, 2014; Connor and Benison, 2013; Oren, 2002), followed by a much less abundant yellow/green fluorescence, which is characteristic of prokaryotes (Benison and Karmanocky, 2014; Conner and Benison, 2013). The blue fluorescence occurred for spherical to elliptical solids ranging from about 5-10 microns in size with a dimpled, yellow appearance, and the yellow/green fluorescence occurred in circular solids, ranging from 2-3 microns. These spherical to elliptical solids with blue fluorescence are suspect Dunalliella algae, which is 
commonly found in brines (Oren, 2002; Connor and Benison, 2013; Benison and Karmanocky, 2014). In modern brines and recently trapped fluid inclusions in halite, Dunaliella algae is commonly associated with beta-carotene, which emits an orange-pink fluorescence under UV light. No orange-pink fluorescence was noted which may mean that any beta-carotene has decayed (Fig 22).
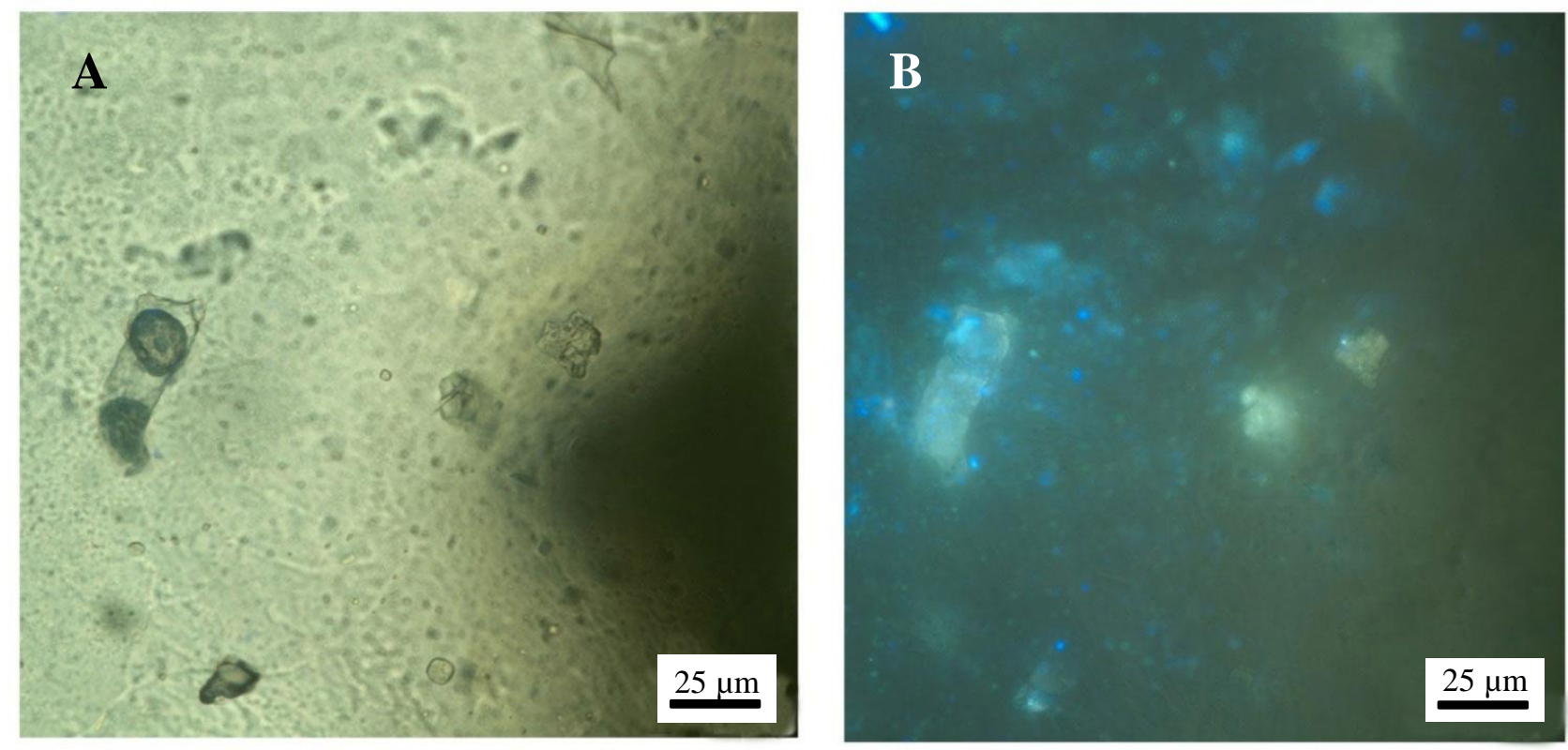

Figure 21. Various fluid inclusions in bedded halite at a depth of 819.6 meters showing UV fluorescence. A) fluid inclusions in plane polarized light. B) The same fluid inclusions under UV light. Blue and yellow/green fluorescence were the dominant colors seen when inclusions where observed using UV light. The smaller, primary inclusions fluoresced blue and the larger, isolated inclusions fluoresced yellow/green.

Because all organisms noted were found within primary fluid inclusions, it can be concluded that they were the organisms that were present in parent shallow saline lake waters at the time of original crystal growth (Mormile et al., 2003). Prokaryotes are significantly smaller than algae bodies, and are far less abundant in fluid inclusions of the Mercia Mudstone. Rare 2-3 micron shapes fluoresced yellow/green under UV light, suggesting that prokaryotes may be present. However, it is possible that due to their small size (2-3 microns), some prokaryotes present in the core may have gone unseen. 


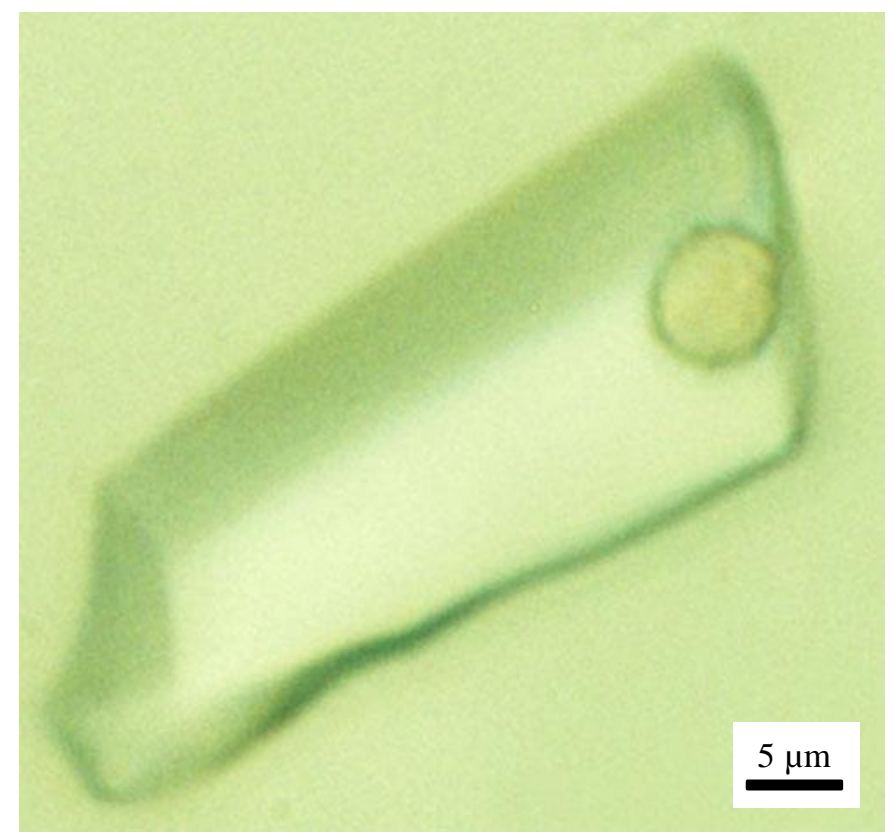

Figure 22. An image of a trapped microbe in a fluid inclusion at a depth of 766.9 meters. Size, shape, and color are consistent with Dunaliella, a halophillic algae.

\section{Freezing-Melting Microthermometry}

Freezing-melting microthermometry runs are useful in determining the chemical composition of liquids within fluid inclusions (Davis et al., 1989; Goldstein and Reynolds, 1994; Hayes, 1985; Janiecki and Benison, 2010). In a study by Davis et al. (1989), fluid inclusions in synthetic halite of various water chemistries were analyzed using freezing-melting microthermometry. During these analyses, Davis never experienced difficulty in freezing his inclusions. Many natural halites have also been subjected to freezing-melting runs and have successfully froze (Benison, 2013; Janiecki and Benison, 2010;). However, the fluid inclusions of the Larne Halite in the Carnduff 2 core failed to freeze after being chilled to a temperature of $-190^{\circ} \mathrm{C}$ for several minutes. Because the same study was performed on modern fluid inclusions from Searles Lake and Western Australia, and ancient samples from the Permian Nippewalla Group of Kansas and Oklahoma with successful results, it was determined that the lack of 
freezing was not due to faulty instruments. Benison (2013) reported that inclusions in the Opeche Shale halite also failed to freeze. The Opeche Shale halite contains the lowest $\mathrm{pH}$ values known from fluid inclusions (Benison et al., 1998). The lack of freezing in the Larne Halite samples indicates that the liquid within the fluid inclusions is likely too extreme in salinity and/or acidity for it to freeze (Benison, 2013).

\section{Laser Raman Spectroscopy}

Laser Raman spectroscopic analyses indicate that some of the bedded halite found within the Larne Halite Member precipitated from acid lake waters. The presence of bisulfate species in Raman spectra is known to be an indication of acid waters (Benison, 2013; Benison et al., 1998; Benison and Goldstein, 2002) as is the presence of acid minerals, such as alunite and jarosite (Benison and Goldstein, 2002; Benison et al, 2007; Janiecki and Benison, 2010; Rudolph and Mason, 2001). In the Larne Halite inclusions, both of these criteria were observed.

The presence of, and number of Raman peaks for bisulfate $\left(\mathrm{HSO}_{4}^{-}\right)$is related directly to pH of the solution. Bisulfate peaks at 422 (Ling et al., 1985; Rudolph and Mason, 2001), 892, and $\sim 1054 \mathrm{~cm}^{-1}$ are all observed only in $\mathrm{H}_{2} \mathrm{SO}_{4}$ rich solutions (Benison et al., 1998; Tomikawa and Kanno, 1998). A study by Benison et al. (1998) analyzed 5 standard solutions of known molar concentrations in synthetic fluid inclusions. The $\mathrm{pH}$ values of the solutions ranged from

-1.5 to 7 . When analyzed, the synthetic inclusions that had a $\mathrm{pH}$ between 0 and 1 yielded spectra that contained a $\sim 1054 \mathrm{~cm}^{-1}$ bisulfate peak (Benison et al., 1998). Synthetic fluid inclusions that had a $\mathrm{pH}$ of less than 0 showed two bisulfate peaks at $\sim 892$, and $\sim 1054 \mathrm{~cm}^{-1}$ (Benison et al, 1998). Therefore, it can be stated that if a natural fluid inclusions contains two bisulfate peaks at $\sim 892$, and $\sim 1054 \mathrm{~cm}^{-1}$, the $\mathrm{pH}$ of the parent waters were less than zero. Likewise, if the natural 
inclusions contain only a $\sim 1054 \mathrm{~cm}^{-1}$ peak, it can be said that the parent waters were less than 1 . Additionally, Rudolph and Mason (2001) created synthetic solutions that were rich in aluminum, and found that a bisulfate peak at $\sim 422 \mathrm{~cm}^{-1}$ was seen in solutions with a $\mathrm{pH}$ of less than '.

In five of the beds analyzed, distinct peaks at $\sim 422 \mathrm{~cm}^{-1}$ were seen (Table 2). This suggests that the halite at these five depths precipitated when the $\mathrm{pH}$ of the water was less than 〜1.5 (Rudolph and Mason, 2001).

Furthermore, in nine of the beds analyzed, there was a distinct peak at $\sim 490 \mathrm{~cm}^{-1}$. According to recent studies (Bishop and Murad, 2005; Breitinger et al., 1997; Frost et al., 2006; Rudolph and Mason, 2001), a peak at $\sim 49 \mathrm{~cm}^{-1}$ is characteristic of aluminum sulfate compounds, such as alunite, in solution. Frost et al. (2006) and Maubec et al. (2012) found that alunite species such as $\mathrm{K}$-alunite, $\mathrm{Na}$-alunite, and $\mathrm{NH}_{4}$-alunite can have multiple bands ranging from 480 to $508 \mathrm{~cm}^{-1}$ due to bending of sulfate, and intense bands at $\sim 235 \mathrm{~cm}^{-1}$ due to hydrogen bond stretching.

Bisulfate and/or aluminum sulfate peaks are present in ten of the analyzed beds, adding further evidence of low $\mathrm{pH}$ being present in the Carnduff 2 inclusions. Frost et al. (2006) also reported that intense bands for solids K-alunite, $\mathrm{Na}$-alunite, and $\mathrm{NH}_{4}$-alunite occurred at 1026, $\sim 1027$, and $\sim 1026 \mathrm{~cm}^{-1}$ respectively, showing a stretching mode of sulfate that only occurs in alunite species. Although Larne Halite beds do not have peaks at 1026 and $1027 \mathrm{~cm}^{-1}$, they do commonly have peaks at $\sim 1020 \mathrm{~cm}^{-1}$. It is known that exact composition of solutions and temperatures can affect the height of and shift of a particular Raman peak (Benison et al., 1998; Myeni, 2000). Because the waters analyzed in the study by Frost et al. (2006) were conducted on synthetic waters, it is likely that the complex chemistry of the natural fluid inclusions varied slightly from simple synthetic waters. This may be responsible for the slight shift in peaks. 


\section{How do the Larne Halite fluid inclusions compare to Modern Salar Gorbea Waters?}

Lake waters from Gneiss Lake ( $\mathrm{pH}$ 1.4) and Lake Aerodrome ( $\mathrm{pH}$ 1.8) of Western Australia and Salar Gorbea (pink water of $\mathrm{pH} 1.6$ and blue water of $\mathrm{pH} 1.8$ ) of Chile were analyzed and their spectra were compared to the results of the Mercia Mudstone fluid inclusion waters.

The Gorbea blue waters show peaks at approximately $1640,984,879$, and a broad peak at $\sim 610 \mathrm{~cm}^{-1}$. The Gorbea pink waters show similar peaks to the Gorbea blue waters, and consist of peaks at approximately 1640 , a broad peak from 1000-1200, 984, 880,620, and $490 \mathrm{~cm}^{-1}$. The peak at $1640 \mathrm{~cm}^{-1}$ is representative of a water peak, the peaks between 1000-1200, 984, 880, and $620 \mathrm{~cm}^{-1}$ are characteristic of sulfate species, and the peak at $490 \mathrm{~cm}^{-1}$ is indicative of aluminum sulfate compounds. When compared with the Gorbea blue and pink waters, a distinct peak in the Larne Halite fluid inclusions at $~ 1131 \mathrm{~cm}^{-1}$ can be seen were a broad, wide peak from 1000-1200 $\mathrm{cm}^{-1}$ is present in both the Gorbea waters. These peaks fall along the range for bisulfate at $\sim 1054$ $\mathrm{cm}^{-1}$, indicating that there could be some bisulfate present. A peak at $490 \mathrm{~cm}^{-1}$ is seen only in the Larne Halite and Gorbea pink waters, indicating the presence of acid minerals, such as alunite. The Gorbea blue water lacks a peak at $\sim 40 \mathrm{~cm}^{-1}$. The lack of a $1054 \mathrm{~cm}^{-1}$ peak confirms that this peak can only be detected in $\mathrm{H}_{2} \mathrm{SO}_{4}$-rich waters with a $\mathrm{pH}$ less than $\sim 1$, as discovered by Benison et al. (1998).

\section{How do the Larne Halite fluid inclusions compare to Lake Aerodrome Waters?}

Lake Aerodrome (Western Australia) waters with a measured $\mathrm{pH}$ of 1.8 contained only Raman peaks for water and sulfate (at $\sim 980 \mathrm{~cm}^{-1}$ ). No other peaks such as bisulfate or aluminum sulfate compounds were seen. Because the $\mathrm{pH}$ for Lake Aerodrome at the time of water sampling 
were greater than one, bisulfate peaks are not expected to be present because they only occur at $\mathrm{pH}$ values less than $\sim 1$.

In general, Raman spectra of Larne Halite fluid inclusions showed peaks for water and sulfate, but also showed peaks at $422 \mathrm{~cm}^{-1}$ in both spectra, and a slight peak at $490 \mathrm{~cm}^{-1}$ for one of the spectra (Fig.17). This indicates that although the spectra observed are similar to the Lake Aerodrome waters (rich in sulfate and suspected low $\mathrm{pH}$ ), they likely have a $\mathrm{pH}$ of less than $\sim 1.5$, which is interpreted by the bisulfate and aluminum sulfate compound peaks as diagnostic indicators of acidity (Benison and Goldstein, 2002; Benison, 2013).

\section{How does the Larne Halite compare to Permian Opeche Shale Fluid Inclusions?}

The Raman spectra of fluid inclusions in bedded halite of the Larne Halite were compared to those of previously documented acid inclusions of the Permian Opeche Shale (Benison et al, 1998). Slight similarities were noted between the Opeche Shale and the Larne Halite, from $985-1020 \mathrm{~cm}^{-1}$, for ten of twelve beds, but such similarities were in inconclusive species such as sulfates. An aluminum sulfate peak at $490 \mathrm{~cm}^{-1}$ was not seen in the Opeche Shale spectra (Fig.18). This may be due to the Opeche containing less potassium and/or aluminum, and therefore not producing an alunite peak.

\section{How does the Larne Halite compare to Permian Nippewalla Group Fluid Inclusions?}

The Larne Halite spectra had some similarities to the Permian Nippewalla Group spectra. Similarities were mainly sulfate species in the ranges of $\sim 984-1020 \mathrm{~cm}^{-1}$ and $\sim 1100-1200 \mathrm{~cm}^{-1}$ (Benison, 1997). Only $15 \%$ of Nippewalla halite had a bisulfate peak, so $85 \%$ of the inclusions had a $\mathrm{pH}$ greater than $\sim 1$ (Benison et al., 1998). Like the Nippewalla Group, there were some beds (depths of 819.6 and 862.4 meters) that did not show any signs of acidity, and only showed 
signs of water and sulfate. Since sulfate peaks alone are not enough to interpret acidity, those beds cannot be concluded to have been the result of waters with a $\mathrm{pH}$ of less than $\sim 1$.

\section{How can hydronium ions indicate acidity?}

Hydronium ions found in fluid inclusions are indicative of acid waters. However, the main stretching mode of hydronium is typically overlapped by strong water peaks at $\sim 3400 \mathrm{~cm}^{-1}$ (Giguere and Gulliot, 1982). Nonetheless, it has been noted that bending bands for hydronium ions can appear in laser Raman spectra if the saturation of $\mathrm{H}_{3} \mathrm{O}^{+}$is greater than $0.23 \mathrm{M}$. These types of peaks typically occur between $\sim 1100$ and $1200 \mathrm{~cm}^{-1}$ and are about one-sixth as intense as water peak at $\sim 1640 \mathrm{~cm}^{-1}$ (Giguere and Gulliot, 1982). Because these peaks are characteristically less intense and are broad $\left(\sim 200 \mathrm{~cm}^{-1}\right.$ wide), they are often undetected unless the concentration is about $0.20 \mathrm{M}$ or greater (Giguere and Gulliot, 1982). Weak bending bands of hydronium ions occur at approximately $1220 \mathrm{~cm}^{-1}$ in a solution that is $0.23 \mathrm{M} \mathrm{H}_{3} \mathrm{O}^{+}$(Giguere and Gulliot, 1982). Far more numerous peaks occurred around $\sim 110$ and $1060 \mathrm{~cm}^{-1}$, both of which are indicative of a solution that is $0.32 \mathrm{M} \mathrm{H}_{3} \mathrm{O}^{+}$. When $\mathrm{pH}$ is calculated using the concentrations of $0.23 \mathrm{M}$ and $0.32 \mathrm{M}$ suggested by Giguere and Gulliot (1985), $\mathrm{pH}$ values of 0.64 and 0.49 respectively are yielded. This type of peak could be seen in several of the Larne Halite beds. 


\section{How is hydronium alunite an indicator of acidity in ancient environments?}

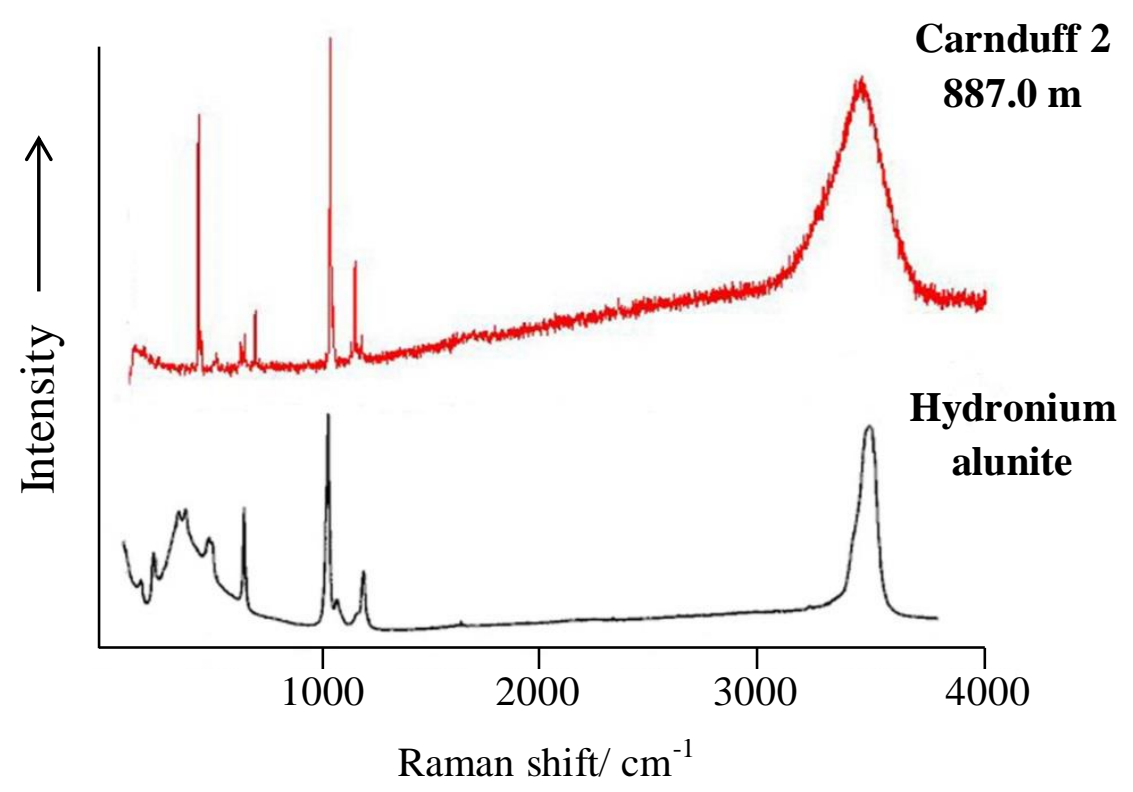

Figure 23. A comparison of Raman spectra for a fluid inclusion in the Larne Halite bed at 887.0 meters and hydronium alunite (modified from Rudolph and Mason, 2001). Matching sulfate peaks and peaks at $\sim 490 \mathrm{~cm}^{-1}$ and $\sim 1017 / 1020 \mathrm{~cm}^{-1}$ indicate that there is hydronium alunite in the Mercia Mudstone samples.

Aluminum species, especially Aluminum III species, such as alunite, are known to be measurable only in very acid solutions (Drever, 1988; Frost et al., 2006; Hemley et al, 1969; Langmuir,1997; Nordstrom 1982a; Ruldolph and Mason, 2001; Soulsby and Reynolds, 1992). Therefore, the presence of aluminum in solution and/or the presence of the mineral alunite, is a criterion for recognizing past acidic waters (Benison and Goldstein, 2002; Benison et al, 2007; Rudolph and Mason, 2001). Another study by Jagniecki and Bension (2010) showed peaks from approximately 400 to $550 \mathrm{~cm}^{-1}$ that were exclusive to acidic inclusions. Bowen and Benison (2009) also noted that the presence of elevated concentrations of aluminum in modern waters in Western Australia with a pH less than 4. Benison and Goldstein (2002) documented high aluminum in acid fluid inclusions in bedded halite in Permian Opeche Shale and Nippewalla 
Group by crush and leachate analyses. Therefore, Raman spectra that display peaks for sulfate species $\left(\mathrm{SO}_{4}{ }^{2-}\right)$ along with a peak at $\sim 490 \mathrm{~cm}^{-1}$ are considered indicative of acid lake waters at the

time of halite precipitation (Fig 23). A Raman peak at $892 \mathrm{~cm}^{-1}$ for bisulfate represents a pH of less than 0 , and a peak at $1054 \mathrm{~cm}^{-1}$ for bisulfate represents a $\mathrm{pH}$ of less than 1 (Benison et al, 1998). There were no peaks at $892 \mathrm{~cm}^{-1}$ or $1054 \mathrm{~cm}^{-1}$ detected in the fluid inclusions of the Larne Halite. Therefore, the $\mathrm{pH}$ is estimated to be acidic, but have a $\mathrm{pH}$ greater than 1 .

\section{Discussion}

\section{Was the Larne Halite deposited in acid lake waters?}

Three notable observations that were seen in the Carnduff 2 core were: double rims on fluid inclusions, a lack of freezing during freezing-melting runs, and bisulfate and alunite indicators in Raman spectra. This combination of observations was compared to criteria described for the recognition of acid lakes and groundwaters in the rock record (Benison and Goldstein, 2002).

Based on study of the Permian Nippewalla Group and Opeche Shale, Bension and Goldstein (2002) determined criteria for ancient acid waters in the rock record. Diagnostic criteria include: (1) the presence of bisulfate in fluid inclusions indicated by laser Raman spectroscopy; (2) high concentrations of $\mathrm{Al}, \mathrm{Fe}$, and/or $\mathrm{Si}$ in fluid inclusions; and (3) the presence of "acid" minerals such as alunite and jarosite (Benison and Goldstein, 2002; Benison, 2013). Along with these diagnostic criteria, there are several other characteristics that are common, but are not considered diagnostic of ancient acidic brines. These indirect signs of acidity are: (1) the remains of acidophilic microbes; (2) the presence of red beds; and (3) the absence of carbonates (Benison and Goldstein, 2002). 
The presence of a double rim on the fluid inclusions of the Larne Halite is suspected to be another criterion that can be used in identifying ancient acidic waters. Aside from the Carnduff 2 fluid inclusions, these rims were noticed on the previously established acidic fluid inclusions of the Opeche Shale of North Dakota, and on acidic, synthetic fluid inclusions with $\mathrm{pH}$ values as low as -1.5 (Fig. 20). Petrography of non-acid fluid inclusions at room temperature has not shown any double rims.

Non-acid inclusions successfully froze when undergoing freezing-melting runs. Davis et al. (1989) conducted an experiment on fluid inclusions of various known, non-acidic water chemistries and did not experience a lack of freezing. Fluid inclusions within the bedded halite of the Larne Halite failed to freeze during freezing-melting runs. Similarly, a lack of freezing has been noted in several other acidic environments. The Permian Opeche Shale fluid inclusions failed to freeze, even after being subjected to a temperature of $-178^{\circ} \mathrm{C}$ for several minutes (Benison, 2013). Likewise, the suspected acid fluid inclusions in the Neoproterozoic Browne Formation of Western Australia have failed to freeze, even after being held at $-190^{\circ} \mathrm{C}$ for several minutes (Jeremiah Bernau, personal communication). This characteristic of fluid inclusions in halite is rare and indicates low $\mathrm{pH}$, high salinity, or a combination of both factors.

Laser Raman spectroscopy on non-acidic fluid inclusions have shown no indications of bisulfate. Winters et al. (2013), used laser Raman spectroscopy to identify carotenoids in ancient salt samples from non-acidic saline lakes in California. Samples from Death Valley, Saline Valley, and Searles Lake all contained spectra that were typical of beta-carotene, but none of the spectra contained peaks that were indicative of bisulfate species at $\sim 1054, \sim 892$, or $\sim 422 \mathrm{~cm}^{-1}$. This shows that bisulfate peaks are characteristic only of sulfuric acid waters within the rock record. 
Based on the diagnostic criteria for recognizing acid lakes and groundwaters, the waters within the fluid inclusions of the bedded halite of the Carnduff 2 core are interpreted as having been formed in shallow, acid, saline perennial lakes. The lake waters likely were $\mathrm{Na}-\mathrm{Cl}-\mathrm{Ca}-\mathrm{SO}_{4}$ rich and contained some $\mathrm{Al}$. The waters showed both the presence of $\mathrm{Fe}$ and $\mathrm{Al}$, and the presence of bisulfate in laser Raman spectroscopy. Non-diagnostic indicators of acidity were noted by the presence of red beds in the core, a lack of carbonates, and the presence of acid minerals in the fluid inclusion waters.

The presence of anhydrite crystals in fluid inclusions and the presence of bottom-growth gypsum pseudomorph crystals also support the interpretation that these ancient lake waters contained calcium and sulfate, along with sodium and chloride. Though these minerals are not diagnostic of acid lakes and groundwaters, they are appropriately associated with many acid, saline lakes. If the lakes formed in environment rich in sulfuric acid, it is understandable that sulfate minerals would form there.

Close association of the Larne Halite with iron oxide mud and kaolinite also suggest the possibility of Fe and K-Al-rich waters. In some Western Australia acid brine lakes, hematite, kaolinite, and alunite precipitate directly from lake waters (Benison et al., 2007). Likewise, laser Raman spectroscopy analyses showed evidence of aluminum rich species in solution in the Larne's Triassic lakes.

The presences of bisulfate and aluminum rich species, such as alunite, are indicators of acidity. In the Carnduff 2 core, both of these criteria are present in multiple beds throughout the core. In five of the twelve analyzed beds, bisulfate peaks at approximately $422 \mathrm{~cm}^{-1}$ were detected. The presence of bisulfate peaks at $\sim 422$ indicates a $\mathrm{pH}$ of less than $\sim 1.5$. Additionally, peaks at $490 \mathrm{~cm}^{-1}$ and approximately $1020 \mathrm{~cm}^{-1}$ were found in all but 3 of the analyzed beds. 
These peaks are indicative of alunite species such as $\mathrm{K}$-alunite and Na-alunite. Alunite species are known to form only in acidic environments with a $\mathrm{pH}$ of less than three. Because the bisulfate and alunite were detected, it is interpreted that these beds formed in shallow lake waters with an extremely low $\mathrm{pH}$ between 1.5 and 3 .

\section{How do the waters of the Larne Halite compare to those found in other ancient and modern acid, saline environments?}

Waters of known acidic $\mathrm{pH}$ were compared to the Larne halite fluid inclusions to see if any trends could be observed. All ancient and modern waters analyzed using laser Raman spectroscopy yielded spectra with a water peak and a peak for sulfate. However, a spectrum for sulfate alone is not enough to determine the $\mathrm{pH}$ of waters. The Gorbea Pink and Blue pool waters (pH 1.6 and 1.8) showed peaks at approximately 1640, 1000-1200, 984, 880, 620, and $490 \mathrm{~cm}^{-1}$ and approximately $1640,984,879$, and $610 \mathrm{~cm}^{-1}$ respectively. The peaks between $1000-1200$, 984, 879-880, and 610 and $620 \mathrm{~cm}^{-1}$ all show sulfate species and are inconclusive in indicating acidity. However, since the $\mathrm{pH}$ values of these lakes are known, it can be concluded that even if a bisulfate peak is not present, the waters can still have a low $\mathrm{pH}$. The peak at $490 \mathrm{~cm}^{-1}$ is representative of aluminum sulfate compounds, which are indicative of a low $\mathrm{pH}$. This $490 \mathrm{~cm}^{-1}$ peak was found in both the Gorbea Blue pool waters and the Larne Halite inclusions. The Lake Aerodrome waters which had a pH of 1.8 contained only a water peak and a sulfate peak at $\sim 980$ $\mathrm{cm}^{-1}$. Fluid inclusions in halite from the Permian Opeche Shale and Nippewalla Groups were also compared to the Mercia fluid inclusions. Similarities between these groups were predominately in the sulfate ranges of $985-1020 \mathrm{~cm}^{-1}$. However, the lack of exact matches between the Mercia Mudstone Group and previously documented acid, saline systems does not 
indicate that the waters are not related. These differences may represent variations in the compositions of natural acid brines.

As can be seen in laser Raman spectra, the absence of a bisulfate peak in any given growth band or bed does not indicate that the waters did not have a low $\mathrm{pH}$. Waters with a $\mathrm{pH}$ of 2 merely showed a sulfate peak in Raman spectroscopy. However, a pH of 2 is still considered acidic. The Raman spectra also vary significantly based on the water composition that is being analyzed. An increase or decrease in any one element, or change in temperature can cause the peaks to vary in location or intensity. Similar to how alkaline lakes have a large range of water chemistries, so do acid, saline lakes. With such complex and unknown chemistries in these acid, saline lake systems, general trends in Raman spectra are enough to deduce that the environment in which the waters were trapped were the same type of environment.

\section{What is the microbiology of the Larne Halite lakes?}

The presence of life was suggested in some fluid inclusions of the Carnduff 2 core. Of the twelve beds analyzed, only three beds contained microbial suspects that could be noted by UVvis fluorescence. Blue and yellow/green were the main fluorescence colors, with rare yellow fluorescence. Fluorescence occurred only in the solids found in select liquid-solid inclusions that were less than ten microns in size. Prokaryotes were also interpreted as being present in the Larne halite, and ranged from about 2-3 microns in size. Size, shape, and fluorescence are all characteristic of microorganisms in fluid inclusions in halite.

It can be concluded that organisms were present in the parent shallow saline lake waters because microbial suspects were found in primary fluid inclusions in bedded halite. Microorganisms that were approximately 5-10 microns in size are interpreted to be Dunaliella 
algae. However, there was not any evidence of pink or orange fluorescence, which is typical of beta-carotene, commonly associated with Dunaliella algae (Conner and Benison, 2013; Lowenstein et al., 2011). This could in part be due to the age of the Larne Halite. Over time, the beta-carotene could have degraded.

Prokaryotes that fluoresced blue and yellow/green are still relatively abundant in the core, despite the age of the Larne Halite. However, due to their small sizes, it is difficult to observe them in plane polarized light. The use of UV light allows for the detection of these microorganisms that may not have otherwise been observed.

The presence of both algae and prokaryotes found within the Carnduff 2 core suggests that at the time of deposition of the Larne Halite, microbial life was able to survive in an extreme, high salinity, low $\mathrm{pH}$ environment. An example of such life can be seen in modern acid saline lakes, such as Lake Magic in Western Australia (Mormile et al., 2009; Conner and Benison, 2013). Further studies such as laser Raman characterization would be advantageous in determining the composition of these ancient microorganisms.

\section{What does Mercia Mudstone reveal about the temporal and spatial extent of acid, saline environments in Pangea?}

The Mercia Mudstone Group is interpreted as having been formed under extreme, acid, saline conditions similar to those found in the Permian Opeche Shale and Nippewalla Groups. Similarities in petrography and water chemistries exist between the Mercia Mudstone Group and these already established acid, saline environments of North America. However, the water chemistries between the Mercia Mudstone and the Opeche Shale and Nippewalla Group are not an exact match. Similarities to the Nippewalla Group could be seen in most of the Larne Halite 
beds by the presence of aluminum sulfate indicator peak at $\sim 490 \mathrm{~cm}^{-1}$. This aluminum sulfate compound peak was not seen in any of the Opeche Shale beds, suggesting that they might not have been as rich in aluminum as the Nippewalla Group or Mercia Mudstone Group.

There are a number of factors that could have contributed to the difference in water chemistries between the two locations. First, the location in Pangea during the time of deposition could have influenced the chemistry of the shallow lake waters. As can be noted in modern environments such as Western Australia, shallow, acid, saline lakes that are only a few kilometers away from each other can have different water chemistries due to diversity in local host sediments and rocks. Therefore, it is likely that even though they formed under similar conditions, the lake waters during the time of northeastern Pangea and equatorial western Pangea had varying water chemistries. Second, there is an age difference between the deposition of the mid-late Permian Opeche Shale and Nippewalla Group and the early Triassic (?) Mercia Mudstone Group. This age difference alone could have contributed to the change in water chemistries. For instance, laser Raman spectroscopy indicates that the Opeche Shale and Nippewalla Group have less aluminum than the Mercia Mudstone Group. It is possible that this difference in composition could be due to brine evolution and/or change in climate between the Permian and Triassic.

Despite slight differences in water chemistries between the Opeche Shale and Nippewalla Group of the equatorial western Pangea and the Mercia Mudstone of northeastern Pangea, they are similar enough to be interpreted as forming under similar physical, chemical, and biological conditions. Therefore, the spatial and temporal extent of extreme acid, saline, shallow lakes and associated mudflats and dunes may have existed over approximately 30 million years and approximately 8,000 kilometers in Pangea. 


\section{Suggestions for Future Work}

This thesis characterized the primary fluid inclusions of the Larne Halite Member of the Triassic Mercia Mudstone; however there are areas in which the work can be continued. To gain a further understanding of the conditions under which the Larne Halite formed, more laser Raman spectroscopy should be conducted, using new complex saline standards that are aluminum and iron rich. This will allow for a more comprehensive study of the Larne Halite beds that show evidence of being aluminum and iron rich.

Conducting homogenization temperature runs may also be beneficial to the overall comprehension of the ancient environment. The homogenization temperature found in primary fluid inclusions of the halite would yield the temperature of the shallow lake waters during the time of evaporite precipitation in the Larne Halite Member.

A comprehensive study of the fluid inclusions found in the Kilroot Salt Mine in Carrickfergus, Northern Ireland would also be beneficial to understanding the extent of these suspected extreme conditions. These rocks are located several kilometers away from the drilling site of the Carnduff 2 core, and could be studied to look for similarities and differences that might exist between the two locations. Furthermore, a comparison between the Mercia Mudstone Group of Northern Ireland and the Mercia Mudstone Group of England could be conducted. A comparison of the two groups could determine whether or not they are rightfully being called by the same name, and if they are similar, does the Mercia Mudstone of England show evidence of acid saline lake deposition? This would allow for a further understanding of localized versus regional patterns in water chemistry. 


\section{Conclusions}

This thesis used petrography, microthermometry and laser Raman spectroscopy to characterize primary fluid inclusions from Triassic lake deposits. Furthermore, this study helps to answer the question of whether or not these evaporites and their inclusions formed in an environment that was extreme-consisting of low $\mathrm{pH}$ value and high salinity.

Combined evidence from this study suggests that the halite of the Mercia Mudstone Group of Northern Ireland, found within the Carnduff 2 core did form under extreme conditions (high salinity and $\mathrm{pH} \sim 1.5-3$ ). This interpretation relies on a combination of evidence as the result of multiple research methods. Detailed fluid inclusion petrography, freezing-melting microthermometry, and laser Raman spectroscopy were all essential methods in determining the extent of acidity and salinity within the Mercia Mudstone inclusions.

Laser Raman spectroscopy offered constraints on $\mathrm{pH}$ values by showing bisulfate peaks

and aluminum sulfate compound peaks in all except two beds analyzed. The appearance of specific bisulfate peaks and aluminum sulfate compound peaks indicates that the parent waters had a $\mathrm{pH}$ of between $\sim 1.5$ and 3 . The presence of alunite also indicates acidity in this range. Furthermore, this study suggests that double rims can be found on fluid inclusions that have formed in an acidic environment. Fluid inclusions within the Mercia Mudstone, as well as a synthetic fluid inclusion with a known $\mathrm{pH}$ of $<1$ both contained a distinct, double rim around the center of the inclusion. However, synthetic and natural water fluid inclusions of high salinity with neutral to high $\mathrm{pH}$ values failed to develop this rim. This indicates that these rims could be exclusive to inclusions of extreme acidity. Currently the process of determining extreme environments in the rock record is challenging and consists of limited criteria. Since these rims 
are not mentioned elsewhere in the literature, it is possible that they could be used as part of a criterion for identifying other ancient, extreme environments.

Finally, this research helped to determine the spatial and temporal extent of long-term, continent-wide acid brine environments. It can be stated that the acid, saline red beds and evaporites found in Mercia Mudstone Group of the Carnduff 2 core of Northern Ireland are comparable to the known acid, saline environments of the Opeche Shale and Nippewalla Groups of the central United States. This means that acid, saline environments in the rock record may have existed for approximately 30 million years, and covered about 8,000 kilometers during the time of Pangea. 


\section{REFERENCES CITED}

Andeskie, A.S., 2016, Depositional and diagenesis history of the Mercia Mudstone Group in the Carnduff 02 core, County Antrim, Northern Ireland, unpublished Master's Thesis, West Virginia University.

Andeskie, A.S., Eichenlaub, L.A., and Benison, K.C., 2015, Preliminary evidence of extreme environments of Pangea: Red beds and evaporites of the Triassic Mercia Mudstone of Northern Ireland, Abstracts with Program, Geological Society of America Annual Meeting, Baltimore, MD.

Armitage, P.J., Worden, R.H., Faulkner, D.R., Butcher, A.R., and Espie, A. A., 2015, Permeability of the Mercia Mudstone: suitability as a caprock to carbon capture and storage sites: Geofluids, v. 16, p.26-42.

Arthurton, R.S., 1973, Experimentally produced halite compared with Triassic layered halite-rock from Chesire., England. Sedimentology, v. 20, p. 145-160.

Benison, K.C., 1997, Acid water deposition and diagenesis in mid Permian red bedhosted evaporites, Midcontinent, U.S.A.

Benison, K.C., 2013, Acid saline fluid inclusions: examples from modern and Permian extreme lake systems: Geofluids, v. 13, p.579-593.

Benison, K.C., Goldstein, R.H., Wopenka, B., Burruss, R.C., and Pasteris, J.D., 1998, Extremely acid Permian lakes and ground waters in North America: Nature, v. 392. p. 911-913.

Benison, K.C., and Goldstein, R.H., 1999, Permian paleoclimate data from fluid inclusions in halite: Chemical Geology, v. 154, p. 113-132.

Benison, K.C., and Goldstein, R.H., 2000, Sedimentology of ancient saline pans: An example from the Permian Opeche Shale, Williston Basin, North Dakota: Journal of Sedimentary Research, v. 70. p. 159-169.

Benison, K.C., and Goldstein, R.H., 2001, Evaporites and siliciclastics of the Permian Nippewalla Groupof Kansas, USA: a case for non-marine deposition in saline lakes and saline pans: Sedimentology, v. 48, p. 165-188.

Benison, K.C., and Goldstein, R.H., 2002, Recognizing acid lakes and groundwaters in the rock record: Sedimentary Geology, v. 151, p.177-185.

Benison, K.C., Janiecki, E.A., Edwards, T.B., Mormile, M.R., and Storrie-Lombardi, M.C., 2008, "Hairy Blobs:" microbial suspects preserved in modern and ancient extremely acid lake evaporates: Astrobiology, v. 8, no. 4, p. 807-821.

Benison, K. C., and Karmanocky, F. J., 2014, Could microorganisms be preserved in Mars gypsum? Insights from terrestrial examples: Geology, v. 42, p. 615-618.

Benison, K.C., Bowen, B.B., Oboh-Ikuenobe, F.E., Jagniecki, E.A., LaClair, D.A., Story, S.L., Mormile, M.R., and Hong, B.Y., 2007, Sedimentology of acid saline lakes in Western Australia: Newly descrived processes and products of an extreme environment: Journal of Sedimentary Research, v. 77, p.366-388. 
Benison, K.C., Zambito, J.J., and Knapp, J., 2015, Contrasting siliciclastic-evaporite strata in subsurface and outcrop: an example from the Permian Nippewalla group of Kansas, U.S.A.: Journal of Sedimentary Research, v. 85, p.626-645.

Benton, M., Cook, E., and Turner, P., 2002, Permian and Triassic Red Beds and the Penarth Group of Great Britian. Geological Conservation Review Series, no. 24, p. 3-28.

Bishop, J.L. and Murad, E., 2005, The visible and infrared spectral properties of jarosite and alunite: American Mineralogist, v. 90, p. 1100-1107.

Bowen, B.B. and Benison, K.C., 2009, Geochemical characteristics of naturally acid and alkaline saline lakes in southern Western Australia: Applied Geochemistry, v. 24, p. 268-284.

Breitinger, D.K., Kriegelstein, R., Bogner, A., Schwab, R.G., Pimpl, T.H., Mohr, J., Schukow, H., 1997, Vibrational spectra of synthetic minerals of alunite and crandallite type: Journal of Molecular Structure, v. 408/409, p. 287-290.

Casas, E., Lowenstein, T.K., 1989, Diagenesis of saline pan halite: comparison of petrographic features of modern, Quaternary, and permian halites: Journal of Sedimentary Petrology, v. 59, p.724-739.

Connor, A.J. and Benison, K.C., 2013, Acidophilic halophilic microorangisms in fluid inclusions in halite from Lake Magic, Western Australia: Astrobiology, v. 13, p. 850-860.

Davis, D.W., Lowenstein, T.K., and Spencer, R.J., 1989, Melting behavior of fluid inclusions in laboratory-grown halite crystals in the systems $\mathrm{NaCl}-\mathrm{H}_{2} \mathrm{O}, \mathrm{NaCl}-$ $\mathrm{KCl}-\mathrm{H}_{2} \mathrm{O}, \mathrm{NaCl}-\mathrm{MgCl}_{2}-\mathrm{H}_{2} \mathrm{O}$, and NaCl-CaCl $2-\mathrm{H}_{2} \mathrm{O}$ : Geochimica et Cosmochimica Acta, v. 54, p. 591-501.

Drever, J.I., 1988, The Geochemistry of Natural Waters, 2nd edition, Prentice-Hall, Englewood Cliffs, NJ, 437.

Elliot, R.E. ,1961, The stratigraphy of the Keuper series in southern Notinghamshire. Proceedings of the Yorkshire Geological Society, v. 33, p.197-231.

Frezzotti, M.L., Tecce, F., and Casagli, A., 2012, Raman spectroscopy for fluid inclusion analysis: Journal of Geochemical Exploration, v. 112, p. 1-20.

Frost, R.L., Wills, R.A., Weier, M.L., Martens, W.W., and Theo Kloprogge, J., 2006, A Raman spectroscopic study of alunites: Journal of Molecular Structure. v. 785, p. 123-132.

Geological Survey of Northern Ireland. (2011, November 25). Retrieved March 29, 2015, from https://www.bgs.ac.uk/gsni/

Giguere, P.A., and Gulliot, 1982, Raman spectrum of $\mathrm{H}_{3} \mathrm{O}^{+}$ions in aqueous acids: The Journal of Physical Chemistry, v. 86, no. 16, p. 3231-3232.

Goldstein, R. H., 2003, Petrographic analysis of fluid inclusions: Fluid Inclusions: Analysis and Interpretation, v. 32, p. 9-54.

Goldstein, R.H., and Reynolds, T.J., 1994, Systematics of fluid inclusions in diagenetic minerals: Society for Sedimentary Geology Short Course 31, p. 1-198. 
Haynes, F. M., 1985, Determination of fluid inclusion compositions by sequential freezing: Economic Geology, v. 80, p.1436-1439.

Hemley, J.J., Hostetler, P.B., Gude, A.J., Mountjoy, W.T., 1969, Some stability relations of alunite: Economic Geology, v. 64, p. 599-612.

Holliday, D.W, Jones, N.S., and McMillan, A.A., 2005, Lithostratigraphical subdivision of the Sherwood Sandstone Group (Triassic) of the north-eastern part of the Carlisle Basin, Cumbria, and adjacent parts of Dumfries and Galloway, UK: Geology and Landscape Northern Britain Programme Internal Report IR/05/148, British Geological Survey, 39.

Howard, A.S., Warrington, G., Ambrose, K., and Rees, J.G., 2008, A formational framework for the Mercia Mudstone Group (Triassic) of England and Wales: Research Report RR/08/04, British Geological Survey.

Jagniecki, E.A. and Benison, 2010, Criteria for the recognition of acid-precipitated halite: Sedimentology, v. 57, p. 273-292.

Langmuir, D., 1997, Aqueous Environmental Geochemistry. Prentice-Hall, Upper Saddle River, NJ.

Ling, Y.C., Vickers, T.J., and Mann, C.K., 1985,Background correction in Raman spectroscopic determination of dimethylsulfone, sulfate, and bisulfate: Applied Spectroscopy, v. 39, p. 463-470.

Lowenstein, T. K., and Hardie, L. A., 1985, Criteria for the recognition of salt-pan evaporates: Sedimentology, v. 32, p. 627-644.

Lowenstein, T.K., Li, J., and Brown, C.B., 1998, Paleotemperatures from fluid inclusions in halite: method verification and a 100,000 year paleotemperature record, Death Valley, CA: Chemical Geology, v. 150, p. 233-245.

Lowenstein, T.K., Schubert, B.A., and Timofeeff, M.N., 2011, Microbial communities in fluid inclusions and long-term survival of halite: GSA Today, v. 21, p.4-9.

Maubec, N., Lahfid, C., Leroughe, C., Wille, G., and Michel, W.K., 2012, Characterization of alunite supergroup minerals by Raman spectroscopy. Spectrochimica Acta Part A: Molecular and Biomolecular Spectroscopy, v. 96, p.925-939.

McCann, N., 1990, The subsurface geology between Belfast and Larne, Northern Ireland: Ireland Journal of Earth Science, p. 157-173.

Mormile, M.R., Biesen, M.A., Gutierrez, M.C., Ventosa, A., Pavlovich, J.B, Onstott, T.C., and Fredrickson, J.K., 2003, Isolation of Halobacterium salinarum retrieved directly from halite brine inclusions: Environmental Microbiology, v. 5, p.10941102.

Mormile, M.R., Hong, B.Y., and Benison, K.C., 2009, Molecular analysis of microbial communities of Mars analog lakes in Western Australia: Astrobiology, v. 9, p. 919-929.

Myneni, S. C. B., 2000, X-ray and vibrational spectroscopy of sulfate in Earth materials, in Sulfate Minerals: Crystallography, Geochemistry, and Environmental 
Significance, Rev. Mineral. Geochem., v. 40, edited by C. N. Alpers, J. L. Jambor, and D. K. Nordstrom, pp. 113-172, Mineral. Soc. of Am., Washington, D. C.

Nordstrom, D.K., 1982a, The effect of sulfate on aluminum concentrations in natural waters: some stability relations in the system Al2O3-SO3-H2O at 298 K: Geochimica et Cosmochimica Acta, v. 46, p. 681- 692.

Oren, A., 2002, Halophilic Microorganisms and Their Environments, Kluwer Academic, Dordrecht, the Netherlands.

Pasteris, J.D., Wopenka, B., Seitz, J.C.,1987, Practical aspects of quantitative laser Raman microprobe spectroscopy for the study of fluid inclusions: Geochimica et Cosmochima Acta, v.52, p. 979-988.

Penn, J.E., Holliday, D.W., Kirby, G.A., Kubala, M., Sobey, R.A., Mitchell, W.I., Harrison, R.K., and Beckinsale, R.D, 1983, The Larne no.2 borehole: discovery of a new Permian volcanic centre: Scottish Journal of Geology, v. 19, p.333-346.

Rosasco, G.J. and Roedder, E., 1979, Application of a new Raman microprobe spectrometer to nondestructive analysis of sulfate and other ions in individual phases in fluid inclusions in minerals: Geochimica et Cosmochima Acta, v. 43, p. 1907-1915.

Rudolph, W.W. and Mason, R., 2001, Sudy of aqueous $\mathrm{Al}_{2}\left(\mathrm{SO}_{4}\right)_{3}$ solution under hydrothermal conditions: sulfate ion pairing, hydrolysis, and formation of hydronium alunite: Journal of Solution Chemistry, v. 30, p. 527-548.

Ruffel, A. and Shelton, R., 1999, The control of sedimentary facies by climate during phases of crustal extension: examples from the Triassic of onshore and offshore England and Northern Ireland: Journal of the Geological Society, London, v. 156, p. 779-789.

Schubert, B.A., Lowenstein, T.K., and Timofeeff, M.N. (2009a). Microscopic identification of prokaryotes in modern and ancient halite, Saline Valley and Death Valley, California. Astrobiology, v. 9, p.467-482.

Schubert, B. A., Timofeeff, M. N., Lowenstein, T. K., \& Polle, J. E., 2010a, Dunaliella cells in fluid inclusions in halite: significance for long-term survival of prokaryotes: Geomicrobiology Journal, v. 27, p.61-75.

Schubert, B.A., Lowenstein, T.K., Timofeeff, M.N., and Parker, M.A., 2010b, Halophilic archaea cultured from ancient halite, Death Valle, California: Environmental Microbiology, v.12 p. 440-454.

Smith, D.B., 1971, Possible displacive halite in the Permian upper evaporite group of northeast Yorkshire: Sedimentology, v.17, p. 221-232.

Soulsby, C., Reynolds, B., 1992, Modelling hydrological processes and aluminum leaching in an acid soil at Llyn Brianne, Mid-Wales: Journal of Hydrology, v. 138, p. 409- 429. 
Sweet, A.C., Soreghan, L.S., Sweet, D.E., Soreghan, M.J., Madden, A.S., 2013, Permian dust in Oklahoma: source and origin for middle Permian (Flowerpot-Blaine) redbeds in Western Tropical Pangaea. Sediment: Geology, v. 284-28, p. 181-196.

Tomikawa, K. and Kanno, H., 1998, Raman study of sulfuric acid at low temperatures: Journal of Physical Chemistry, v. 102, p.6082-6083.

Verkaaik, M.F.C., Hooijschuu, J.H., Davies, G.R., and Ariese, F., 2015, Raman sprectroscopic techniques for planetary exploration: detecting microorganisms through minerals: Astrobiology, v. 15, p. 697- 707.

Winters, Y.D., Lowenstein, T.K., and Timofeef, M.N., 2013, Identification of Carotenoids in ancient salt from Death Valley, Saline Valley, and Searles Lake, California, using laser Raman spectroscopy: Astrobiology, v. 13, p. 1065- 1080.

Zambito, J. J., and Benison, K. C., 2013, Extremely high temperatures and paleoclimate trends recorded in Permian ephemeral lake halite: Geology, v. 41, 587-590. 


\section{Appendix A: \\ Stratigraphic Descriptions of the Mercia Mudstone Group in the Carnduff 2 core.}






- sedimentary characteristics: very common rip up clasts, halite crystals are subrounded to subangular,the amount of halite increases as you move up in section, halite cement,rip up clasts are angular in shape, no $\mathrm{HCl}$ reaction from this point on

- diagenetic features:halite cement

$6 \quad 939-937.9$

Bedded Halite

- color: halite 5 YR 6/4, mud GLEY 2 4/10B

- sedimentary characteristics: rare mud clasts, rare displacive halite in clasts, kaolinite clay,difficult to see bedding, but can definitely see bottom growth crystal structure, no reaction to $\mathrm{HCl}$

- diagenetic features: recrystallization of halite? 
8

936-933.4

9

933.4-932.2

10

$932.2-929.6$

11

$929.6-928.7$

12

13

14

$925.9-925.5$

15
Displacive Halite that is Mud Rich

- color: halite 5 YR 6/6, mud 2.5 YR 3/3

- sedimentary characteristics: subangular to subrounded halite crystals, mud content $=30 \%$, no bedding seen, no reaction to $\mathrm{HCl}$

Displacive Halite that is Mud Rich

- color: halite 5 YR 6/6, mud 2.5 YR 3/3

- sedimentary characteristics: $60 \%$ mud, $40 \%$ halite, mud is relatively massive and well sorted, no bedding is seen, sharp angular contacts between salt and mud

- diagenetic features: reduction spots?

Displacive Halite

- not bagged, salt dissolved and core is in pieces

- color: mud 2.5 YR 3/3, halite same as unit 8, sylvite 10 YR 5/8

- massive and well sorted mud clasts

Displacive Halite

- color: halite 7.5 YR 5/1, mud Gley 2 5/5BG

- $85 \%$ halite

- $15 \%$ mud

- mud clasts are $\sim 2-3 \mathrm{~cm}$ wide

- mud is well sorted and relatively massive

- abundance of salt increases as you move up in section

- diagenetic features: sylvite veins

Bedded Halite

- color: clear and cloudy white

- no sedimentary characteristics

- $\quad$ sharp contact with units 11 and 13

- small fractures within the salt

Displacive Halite

- color:halite is dark brown and clear and cloudy, mud 2.5 YR 3/3 (chocolate brown)

- sedimentary characteristics:90\% halite, $10 \%$ mud, cubic halite crystals are subrounded in shape, rare mud clasts, no bedding is seen,some reduction? of mud. Color appears to bleed, creating a gradient

Bedded Halite

- color: muddy halite 2.5 YR 4/4, mud chocolate brown and gray (Gley 2 $5 / 10 \mathrm{BG})$

- sedimentary characteristics: clear halite at the bottom and it gets progressively muddier up section

- bedding and contacts: $1 / 2 \mathrm{~cm}$ thick lamina of mud, some bedding? muddiness of halite makes it difficult to identify distinct beds

- diagenetic features: pseudomorph gypsum crystal texture? reduction gradient? mud lamina

Mudstone

- color: mud is chocolate brown

- sedimentary characteristics: climbing ripples $\sim 1 \mathrm{~cm}$ thick at the bottom of the unit, no contacts in bedding

- diagenetic features: gypsum stringers $10 \mathrm{R} 5 / 8$, few reduction spots,gypsum efflorescence on the core due to not being wrapped in plastic 
Mudstone

- color: Gley 2 3/10G

- high clay content

- kaolinite?

- very distinctive blueish gray color

- diagenetic features: reduction gradient? gypsum stringers, same color as unit 15

$925-923.8$

Displacive Halite

- color: halite is brown and glassy, mud is chocolate brown

- sedimentary characteristics: $10 \%$ mud, high clay content,relatively massive mud

$18 \quad 923.8-920$

Missing Core

$19 \quad 920-919.5$

Displacive Halite

- color: same as unit 17

- sedimentary characteristics: $90 \%$ halite, $10 \%$ mud, cubic displacive halite crystals

Bedded Halite

- color: halite glossy and chocolate brown in color, mud is chocolate brown

- sedimentary characteristics: large bottom growth halite crystals, common mud clasts

- bedding and contacts: distinct bedding from crystal shape and mud

- diagenetic features: pseudomorph gypsum splays?

$21 \quad 918.5-916.4$

$22 \quad 916.4-915$

Missing Core

Mixed Displacive and Bedded Halite

- color: mud is chocolate brown, halite is a pink color 5 YR 7/6, halite is also a brown color that is both 2.5 YR 4/2 and 2.5 YR 3/2

- sedimentary characteristics: displacive halite is composed of small crystals with very rare mud, $\sim 7 \mathrm{~cm}$ thick displacive halite region, bedded halite with large bottom growth crystals, $90-95 \%$ halite,5-10\% mud

- bedding and contacts: bedded halite beds are $2 \mathrm{~cm}$ thick

- diagenetic features: potentially recrystallized gypsum

Bedded Halite

- color: mud is a blueish green Gley $25 / 10 \mathrm{~GB}$,halite is same as 22

- sedimentary characteristics: varying halite crystal size, all crystals are subrounded in shape, mud is wavy discontinuous lamina

- bedding and contacts:distinct beds with layers of mud draped over beds, bed layers are composed of varying sized halite crystals and mud

- diagenetic features: dissolution pipes filled with clear halite

Bedded Halite

- color: halite is the same as unit 22, mud is chocolate brown

- sedimentary characteristics: upward growing, needle-shaped crystals,rare mud drapes, beds alternate dark and light in color

- diagenetic features: bottom growth gypsum pseudomorphs creating needle-shaped crystals

25 914.4-912.5 Displacive Halite

- color: mud is same as 24 , halite is the same as 24

- sedimentary characteristics: subangular, displacive halite crystals surrounded by mud

- bedding and contacts:layers of mud with sharp boundaries to the salt, uncommon bedded halite layers that $\sim 2 \mathrm{~cm}$ thick 
- diagenetic features:dissolution pipes filled with clear halite, reduced mud? shown by a color gradient

Mixed Bedded and Displacive Halite

- color: mud is chocolate grown and Gley $25 / 10 \mathrm{~GB}$, halite is glassy and brown

- sedimentary characteristics: upward pointing bottom growth halite crystals, cubic, displacive halite crystals

- bedding and contacts: rare mud drapes found with the displacive halite crystals, gradual contacts from displacive to bedded

$27 \quad 911.3-910.9 \quad$ Mudstone

- color: mud is Gley 2 4/5B and red 10R 3/3

- sedimentary characteristics: well sorted and relatively massive mud with one displacive halite cube in the middle of the mudstone

- bedding and contacts: bedding is defined by color laminations

- diagenetic features: 4 fractures through the mudstone that could potentially be related the displacive halite cube

- color: mud is the same as unit 26 , halite is 5 YR $7 / 4$

- sedimentary characteristics:upward bottom growth halite crystals, mud lamina, uncommon displacive halite cubes

- bedding and contacts:bedding is very well defined between the mud and the halite crystal shape

- diagenetic features: recrystallized gypsum pseudomorphs?

29 910.6-908.8 Missing Core

$30 \quad 908.8-907.9 \quad$ Mudstone

- color: 5 YR 4/3

- sedimentary characteristics: ped-like structure, slickens on surface, no true bedding, relatively massive

- bedding and contacts: no bedding is seen

- diagenetic features: sylvite veins, reduction zones?

$31 \quad$ 907.9-907.8 Bedded Halite

- color: glassy pink 2.5 YR 7/6

- sedimentary characteristics: chevrons

- bedding and contacts:beds from the crystal shape, very thin, discontinuous mud drapes

$32 \quad 907.8-906.7 \quad$ Mixed Bedded and Displacive Halite

- color: same as unit 26

- sedimentary characteristics: same as unit 26

- bedding and contacts: no bedding seen

- diagenetic features: gypsum pseudomorph needles growing upwards, dissolution pipes filled with clear halite

33 906.7-906.6 Bedded Halite

- color: same as unit 31

- sedimentary characteristics: faint chevrons

- bedding and contacts: sharp contact with unit 32 and 34

- diagenetic features: some pseudomorph gypsum textures at the bottom of the samples

34 906.6-905.4 Mixed Bedded and Displacive Halite

- color: same colors as unit 22 


\section{Mudstone}

- color: chocolate brown

- sedimentary characteristics: well sorted, relatively massive

- bedding and contacts: no bedding seen

- diagenetic features: sylvite veins, reduction zones?

36 902.6-901.7 Displacive Halite

- color: grey mud, glassy, brown halite

- sedimentary characteristics: subangular to subrounded crystals with mud clasts

- bedding and contacts: no bedding seen

- diagenetic features: sylvite veins,some reduction?

37 901.7-901.3 Bedded Halite

- color: brown to tan halite 2.5 YR 2.5/2 and 7 YR 6/4, mud is a dark grey color

- sedimentary characteristics: chevrons? in the lower unit, as you move up in section, mud abundance increases, discontinuous mud drapes

- bedding and contacts: distinct halite beds from varying color and crystal shape

- diagenetic features: gypsum pseudomorphs?

$38 \quad 901.3-901$

Displacive Halite

- color: same as 22

- sedimentary characteristics: subangular crystals

- bedding and contacts: sharp contacts with units 37 and 39

- diagenetic features: potentially some gypsum pseudomorphs

$39 \quad 901-900.8$

Bedded Halite

- color: same as 37

- sedimentary characteristics: chevrons

- bedding and contacts: very distinct beds by color variation

$40 \quad 900.8-899.6$

Mixed Bedded and Displacive Halite

- color: same as 22 with a dark grey mud

- sedimentary characteristics: discontinuous mud layers, distinctive cubic halite crystals

- bedding and contacts: gradual change from bedding to displacive

- diagenetic features: sylvite veins, gypsum pseudomorphs

$41 \quad 899.6-899$

Mudstone

- color: Gley 2 5/10GB

- sedimentary characteristics: relatively massive mud with a rare floating, displacive halite crystal

- bedding and contacts: no bedding seen

- diagenetic features: reduction spots?

$42 \quad 899-890.6$

Mixed Bedded and Displacive Halite

- color: same as 22

- sedimentary characteristics: rare mud drapes; subangular, displacive halite crystals that vary in size; bottom growth, bedded halite crystals

- bedding and contacts: beds are defined by color variations, mud drapes

- diagenetic features: sylvite veins, dissolution pipes filled with clear halite 
Eichenlaub, L.A., 2016

43

44

45

46

$884.5-883.5$

47

48

49

50

51

890.6-887.7 Displacive Halite that is Mud Rich

- color: mud is chocolate brown and grey

- sedimentary characteristics: well sorted, relatively massive, high clay content

- bedding and contacts: no bedding seen

- diagenetic features: sylvite veins

887.7-884.7 Mixed Bedded and Displacive Halite

- color: mud is chocolate brown; halite is the same as unit 26

- sedimentary characteristics: chevrons, rare mud drapes, halite crystals are smaller sized near the mud drapes, one bright red mud layer on a halite bed

- bedding and contacts:bedding in the halite is from colors in the crystals and mud drapes

884.7-884.5 Mudstone

- color: mud is choco ate brown

- sedimentary characteristics:rare, very large, cubic, displacive halite crystals

- bedding and contacts: no bedding seen

- diagenetic features: sylvite veins

Bedded Halite

- color: same as unit 26 for both mud and halite

- sedimentary characteristics:large upward growing halite crystals, discontinuous mud drapes

- bedding and contacts:light to dark colored beds of halite, mud drapes $\sim 0.5 \mathrm{~cm}$ thick

- diagenetic features: few fractures and dissolution pipes filled with halite 883.5-881.7 Missing Core 881.7-880.1 Mixed Bedded and Displacive Halite

- color: same as 26

- sedimentary characteristics: larger bottom growth crystals present

- bedding and contacts: halite beds are evident due to color differences

- diagenetic features: sylvite veins, dissolution pipes with clear halite, fractures

880.1-879.3 Displacive Halite

- color: grey mud, same pink/brown salt

- sedimentary characteristics: $10 \%$ mud, $90 \%$ halite, cubic displacive halite crystals

- bedding and contacts: no bedding seen

- diagenetic features: sylvite veins, fractures

879.3-878.6 Mixed Bedded and Displacive Halite

- color: same colors as unit 48

- sedimentary characteristics: $15-20 \%$ mud, large variation in crystal size, discontinuous mud drapes

- bedding and contacts: varying bed thickness depending on crystal size

- diagenetic features: reduction? in mud

Mudstone

- color: chocolate brown and grey mud

- sedimentary characteristics: ped-like texture, rare displacive halite crystals, high clay content

- bedding and contacts:no true bedding

- diagenetic features: sylvite veins, reduction? in the mud 
Eichenlaub, L.A., 2016

- color: same colors as unit 48

- sedimentary characteristics: large (3 cm wide) cubic, displacive halite crystals; crystals are subangular in shape; $15-20 \%$ mud

- bedding and contacts: no bedding seen

- diagenetic features: sylvite veins, reduction? in mud

- color: pink halite (2.5 YR 7/ 8), grey mud

- sedimentary characteristics: bottom growth halite crystals, kaolinite drapes seen in slab

- bedding and contacts: distinct halite beds from color and the upward growth of crystals

- diagenetic features: sylvite veins, reduction? in the mud

- color: same as unit 49

- sedimentary characteristics: mixed textures from crystal shape; cubic, small, displacive crystals; larger bottom growth crystals

- bedding and contacts: bedding seen in crystal size

- diagenetic features: sylvite veins and gypsum pseudomorph splays

$55 \quad 871.5-869.6$

\section{Bedded Halite}

- color: chocolate brown mud, same halite as 48

- sedimentary characteristics: crystal size varies, $15 \%$ mud, kaolinite?

- bedding and contacts: bedded halite seen in crystals, mud drapes

- diagenetic features:gypsum pseudomorphs in needle-like shape

$56 \quad 869.6-869.5$

Bedded Halite

- color: glassy pink/orange 7.5 YR $7 / 8$

- sedimentary characteristics: relatively clear halite with chocolate brown mud clasts suspended in halite

- bedding and contacts: bedding in crystal shape

\section{Bedded Halite}

- color: same as 49

- sedimentary characteristics: subrounded to subangular halite crystals

- bedding and contacts: beds defined by color and rare mud laminations

- diagenetic features: reduction? in mud Mudstone

- color: chocolate brown mud with mixed grey mud, grey colors are Gley 2 6/10GB and Gley 2 4/10B

- sedimentary characteristics: rare displacive halite crystals, mud is well sorted and relatively massive

- bedding and contacts:no bedding seen

- diagenetic features: reduction? lamina

- color: same as 56

- sedimentary characteristics: 5\% mud, upward growing halite crystals, very rare displacive halite crystals found in mud

- bedding and contacts: well defined beds with some mud layers, clear halite, and muddy halite

- diagenetic features:bedded gypsum pseudomorphs, halite-filled dissolution pits

$60 \quad 862-861.3 \quad$ Displacive Halite that is Mud Rich 
- color: chocolate brown the Gley 2 4/10B mud

- sedimentary characteristics: $90 \%$ mud, $10 \%$ displacive halite, abrupt change in color from brown to grey halfway through the unit

- bedding and contacts: no bedding seen

- diagenetic features: sylvite veins

Bedded Halite

- color: grey and chocolate brown mud, glassy brown halite

- sedimentary characteristics: $15-20 \%$ mud, kaolinite seen in mud, rare chevrons

- bedding and contacts: great bedding defined by crystal growth

- diagenetic features: sylvite veins, reduction? in mud, pseudomorph, bottom growth gypsum

$62 \quad 857.6-856.1 \quad$ Displacive Halite that is Mud Rich

- color: same colors as 59

- sedimentary characteristics:abundance of mud increases as you move up unit, cubic, displacive halite crystals that are consistent in size

- bedding and contacts:no bedding seen

- diagenetic features: sylvite veins, clear halite in dissolution pipes, reduction? in mud

63 856.1-854.4 Missing Core

64 854.4-853.2 Mixed Bedded and Displacive Halite

- color: same colors as 53

- sedimentary characteristics: $20 \%$ mud

- bedding and contacts: evident bedding, but hard to see with so much mud

- diagenetic features: reduction? in mud, dissolution pits filled with halite?

$65 \quad 853.2-852.5$

Displacive Halite that is Mud Rich

- color: same as 61

- sedimentary characteristics: large, cubic, displacive halite crystals; mud is relatively massive, but breaks apart like peds

- bedding and contacts: no bedding seen

- diagenetic features: sylvite veins, reduced? mud

$66 \quad 852.5-848 \quad$ Missing Core

$67 \quad 848-846 \quad$ Displacive Halite

- color: same as 63

- sedimentary characteristics: the mud breaks apart like peds

- bedding and contacts: no beds seen

- diagenetic features: reduction? spots, sylvite veins

$68 \quad 846-845.8 \quad$ Bedded Halite

- color: chocolate brown and grey mud, pink/brown halite

- sedimentary characteristics: 5-10\% mud, moderately clear halite, large crystals interbedded with muddy halite and rare displacive halite crystals

- bedding and contacts:very well defined bedding by crystal size

- diagenetic features: potentially some halite dissolution

$69 \quad 845.8-845.6 \quad$ Displacive Halite

- color: same colors as 68

- sedimentary characteristics: mud content increases as you move upward

- bedding and contacts:very faint bedding at the bottom of the unit

- diagenetic features: dissolution pits filled with clear halite

$70 \quad 845.6-845.5 \quad$ Mudstone

- color: chocolate brown

- sedimentary characteristics: rare displacive halite crystals, very massive 
Eichenlaub, L.A., 2016

- bedding and contacts: no bedding seen

- diagenetic features: sylvite veins

Displacive Halite that is Mud Rich

- color: chocolate brown rare spots of grey, glassy brown halite

- sedimentary characteristics: cubic, displacive halite crystals; $80 \%$ mud; formed in mud drapes with slicken features

- bedding and contacts: no bedding seen

- diagenetic features: abundant amount of sylvite veins, halite filled dissolution pits, reduction? in mud

\section{- 844.5-844.3 Bedded Halite}

- color: pink/brown halite, grey/chocolate brown mud

- sedimentary characteristics: rare mud clasts that are approximately $0.25 \mathrm{~cm}$ thick

- bedding and contacts: alternating light and dark colored beds of halite

- diagenetic features: gyspum pseudomorph needles $\sim 1-2 \mathrm{~cm}$ long, reduction? in mud

Mixed Bedded and Displacive Halite

- color: chocolate brown mud, glassy pink and brown halite

- sedimentary characteristics: $0.5-1 \mathrm{~cm}$ wide cubic halite crystals, $15 \%$ mud

- bedding and contacts: bedding of halite formed by upward growth crystals

- diagenetic features:dissolution pits filled with clear halite

$74 \quad 843.5-843.2$

Displacive Halite that is Mud Rich

- color: same as unit 69

- $\quad$ sedimentary characteristics: same as unit 69

- bedding and contacts: same as unit 69

- diagenetic features: sylvite veins, reduction spots?

$75 \quad 843.2-842.7 \quad$ Bedded Halite

- color: same as 70

- sedimentary characteristics: same as 70 except for their only being 5\% mud

- bedding and contacts: same as 70

- diagenetic features: same as 70

$76 \quad 842.7-842.1 \quad$ Displacive Halite

- color: same as unit 69

- sedimentary characteristics: same as unit 69 except there is $15 \%$ mud

- bedding and contacts: same as unit 69

- diagenetic features:same as unit 69

\section{Bedded Halite}

- color: same as unit 70

- sedimentary characteristics: same unit 70 except there is 5\% mud

- bedding and contacts: contacts are the same as unit 70

- diagenetic features: dissolution pipes filled with clear halite, suspended mud clasts

$78 \quad$ 841.2-841.1 Displacive Halite that is Mud Rich

- color: chocolate brown and grey mud, glassy brown halite

- sedimentary characteristics: some cubic, displacive halite crystals suspended in mud, mud is $\sim 60 \%$

- bedding and contacts: no bedding is seen

- diagenetic features: sylvite veins 
Eichenlaub, L.A., 2016

841.1-839.6 Bedded Halite

- color: same as unit 70

- sedimentary characteristics: same as unit 70, except there is $15 \%$ mud

- bedding and contacts: same as unit 70

- diagenetic features: dissolution pipes filled with halite

$80 \quad 839.6-839.4 \quad$ Displacive Halite that is Mud Rich

- color: same as unit 78

- sedimentary characteristics: $70 \%$ mud, subrounded, displacive halite crystals

- bedding and contacts: no bedding seen

- diagenetic features: sylvite veins, reduction? in mud

81 839.4-837.8 Mixed Bedded and Displacive Halite

- color: glassy brown halite, chocolate brown mud

- sedimentary characteristics: $25 \%$ mud, mud drapes, bottom growth halite crystals, cubic, displacive halite crystals suspended in mud

- bedding and contacts:defined by the bottom growth crystals

- diagenetic features: some pseudomorph gypsum crystals

$82 \quad 837.8-837.5 \quad$ Bedded Halite

- color:

○ glassy, dark brown halite

- chocolate brown mud

- sedimentary characteristics

○ $10 \%$ mud

- large halite bottom growth crystals with chevrons?

- bedding and contacts:

$\bigcirc \quad$ very well defined by halite crystal size and shape

- diagenetic features:

$83 \quad 837.5-837.3 \quad$ Mudstone

$\circ \quad$ gypsum pseudomorph crystals

- color: chocolate brown mud

- sedimentary characteristics: extremely crumbly, breaks into peds, rare displacive halite crystals

- bedding and contacts: no bedding seen

- diagenetic features: sylvite veins

$84 \quad 837.3-837$

Bedded Halite

- color:glassy brown to pink halite, chocolate brown mud

- sedimentary characteristics: $15 \%$ mud found in mud drapes

- bedding and contacts:great bedding defined by bottom growth crystals

- diagenetic features: pseudomorph gypsum crystals

Mixed Bedded and Displacive Halite

- color: same as unit 82

- sedimentary characteristics: bedded bottom growth halite, displacive halite crystals in muddier areas

- bedding and contacts: some nicely defined beds throughout the unit

- diagenetic features: sylvite veins, gypsum pseudomorph crystals

86 836.5-836 Displacive Halite

- color: grey and chocolate brown mud, glassy brown halite

- sedimentary characteristics: large displacive halite crystals $\sim 2 \mathrm{~cm}$ in width, $15 \%$ mud 
- bedding and contacts: sharp contacts with unit 85 and 87

$88 \quad 835.9-834.6$

- diagenetic features: some sylvite veins, beginning of reduction zone?

Mudstone

- color: chocolate brown mud to dark grey mud

- sedimentary characteristics: rare displacive halite crystal, well sorted

- bedding and contacts:bedding in the mudstone alternating from grey to brown

- diagenetic features:grey gradient indicating reduction?

Displacive Halite that is Mud Rich

- color: chocolate brown mud, glassy brown halite

- sedimentary characteristics: large, displacive crystals, $70 \%$ mud

- bedding and contacts:no bedding seen

- diagenetic features: some reduction? in mud, dissolution pipes filled with clear halite

89 834.6-834.4 Mudstone

- color: chocolate brown and grey mud

- sedimentary characteristics: slickens, crumbles into peds, relatively massive

- bedding and contacts: no bedding seen

- diagenetic features: reduction gradient? in mud

$90 \quad$ 834.4-832.9 Mixed Bedded and Displacive Halite

- color: chocolate brown to grey mud, glassy brown halite

- sedimentary characteristics: cubic, displacive halite crystals, $40 \%$ mud, minor mud drapes

- bedding and contacts:bedding in bottom growth crystals

- diagenetic features:dissolution pipes filled with clear halite, reduction of mud?

91 832.9-832.6 Displacive Halite that is Mud Rich

- color: chocolate brown mud, glassy brown halite

- sedimentary characteristics: 60-80\% mud, large displacive halite crystals

- bedding and contacts: no bedding evident

- diagenetic features: sylvite veins

92 832.6-831.4 Displacive Halite

- color: same as unit 86

- sedimentary characteristics: $40 \%$ mud, large, cubic halite crystals

- bedding and contacts: very minor and rare beds

- diagenetic features: small sylvite veins, dissolution pipes filled with halite

$93 \quad 831.4-830.9 \quad$ Mudstone

- color: mud is chocolate brown to grey

- sedimentary characteristics: rare (2-3) displacive halite crystals

- bedding and contacts: massive mud, no bedding

- diagenetic features: thin sylvite veins, reduction spots?

$94 \quad 830.9-829.9$ Displacive Halite that is Mud Rich

- color: mud is chocolate brown, halite is brown

- sedimentary characteristics: $70-75 \%$ at bootom, $60 \%$ at top; small displacive crystals

- bedding and contacts: no bedding, straight chaos

- diagenetic features: very thin sylvite veins

$95 \quad 829.9-829.3 \quad$ Bedded Halite 
96
- color: mud is chocolate brown, halite is brown

- sedimentary characteristics: 5-10\% mud as drapes clasts, rare displacive

- bedding and contacts: beds defined by crystal shape

- diagenetic features: minor reduction in mud

Mixed Bedded and Displacive Halite

- color:

- mud is chocolate brown

- halite is brown

- sedimentary characteristics

- $10-15 \%$ mud

○ cubic crystals

$\circ$ same mud content throughout

- bedding and contacts:

$\circ \quad$ very faint bedding

- 1-2 cm thick bed of mud

$\circ \quad \sim 1$ sylvite in it

- diagenetic features:

○ small reduction amount in mud

Bedded Halite that is Mud Rich

- color: mud is chocolate brown and grey, halite is brown

- sedimentary characteristics: some mud drapes, 5\% mud

- bedding and contacts: distinct beds muddied with mud drapes

- diagenetic features: potentially some pseudomorph gypsum splays

Displacive Halite that is Mud Rich

- color: mud is grey,halite is brown

- sedimentary characteristics: cubic displacive crystals

- bedding and contacts: no evident bedding

- diagenetic features: sylvite veins

Bedded Halite

- color: mud is chocolate brown, brown clear halite

- sedimentary characteristics: repetitive texture from beds with crystal side up; as you go up from mud and then more mud

- bedding and contacts: great beds defined by both mud and crystals, clear contact

- diagenetic features: pseudomorph gypsum crystals

825.6-824.4 Mixed Bedded and Displacive Halite

- color: mud is dark chocolate brown to grey

- sedimentary characteristics: $15 \%$ mud, mixed crystal size

- bedding and contacts: distinct halite beds growing upward

- diagenetic features: pseudomorph gypsum crystals, reduction gradient in mud? halite veins

824.4-823.7 Bedded Halite

- color: same as 99

- sedimentary characteristics: well bedded with clear and slightly muddy $(10 \%)$ halite

- bedding and contacts: beds alternate in thickness and are very clear

- diagenetic features:clear halite in dissolution pipes

Missing Core

Bedded Halite

- color: mud is chocolate brown, halite is clear brown 
- sedimentary characteristics: some floating mud chips/clasts, $10 \%$ mud

- bedding and contacts: bedding is very clear

- diagenetic features: maybe few dissolution pipes?

- color: mainly chocolate brown with hazes of grey

- sedimentary characteristics: well sorted mud

- bedding and contacts: massive, no bedding

- diagenetic features: sylvite veins

105 818.05- 817.5 Mixed Bedded and Displacive Halite

- color: mud is chocolate brown, halite is brown

- sedimentary characteristics: $15 \%$ mud

- bedding and contacts: gradual contacts with faint bedding

- diagenetic features: dissolution pipes with halite

$106 \quad 817.5-814.3$ Bedded Halite

- color: halite color is the same,mud is gray $10 \mathrm{R} 4 / 14$

- sedimentary characteristics: kaolinite, new reddish color

- bedding and contacts: very clear bedding

- diagenetic features: dissolution pipes pipes in halite, reduction in mud

$107 \quad 814.3-814 \quad$ Mudstone

- color: purple brick $10 \mathrm{R} 3 / 2$ and Gley 2 3/5BG

- sedimentary characteristics: rare displacive crystals, mud is fairly massive

- bedding and contacts: no bedding

- diagenetic features: reduction gradient?

108 814-813.6 Bedded Halite

- color: dark brown halite, gray mud

- sedimentary characteristics: same as 103

- bedding and contacts: clear contact between 107 and 108

- diagenetic features: gypsum pseudomorph splays

109 813.6-813.1 Mudstone

- color: purple brick and grey mud

- sedimentary characteristics: very rare displacive halite crystals

- bedding and contacts: very sharp contacts between units 108 and 109, no bedding seen

110 813.1-812.6 Bedded Halite

- color: mud is grey and chocolate brown, brown halite

- sedimentary characteristics: rare displacive crystals

- bedding and contacts: sharp contact with 109 , faint bedding

- diagenetic features: pseudomorph gypsum needles

$111 \quad 812.6-812.2 \quad$ Mudstone

- color: chocolate brown to grey mud

- sedimentary characteristics: same as 109

- bedding and contacts: no bedding seen

- diagenetic features: sylvite veins

112 812.2-811.4 Mixed Bedded and Displacive Halite

- color: chocolate brown and gray mud, brown halite

- sedimentary characteristics: mud drapes, mud is $10 \%$, large variety in crystal size

- bedding and contacts: well defined beds

- diagenetic features: sylvite veins 
Eichenlaub, L.A., 2016

113

114

115

116

117

118

119

120

121
$810.2-809.6$

809.6-808.8

811.4-810.4

$810.4-810.2$

$808.8-807.6$

807.6-807

807-801.6

801.6-801.4

801.4-799.8
Displacive Halite that is Mud Rich

- color: chocolate brown mud,brown halite

- sedimentary characteristics: $70-80 \%$ mud, large sized, cubic halite crystals, mud is massive

- bedding and contacts: no bedding seen

- diagenetic features:dissolution pipes filled with clear halite, sylvite veins

Bedded Halite

- color: chocolate brown mud, dark brown halite

- sedimentary characteristics: $5-10 \%$ mud

- bedding and contacts:very well-defined beds, sharp contact with unit 115 Displacive Halite

- color: grey and chocolate brown mud, brown halite

- sedimentary characteristics: large displacive crystals

- bedding and contacts: no evident bedding

- diagenetic features: sylvite veins, dissolution pipes filled with clear halite Mixed Bedded and Displacive Halite

- color: chocolate brown mud,brown/pink halite

- sedimentary characteristics: $25 \%$ mud, distinct upward growth halite crystals, cubic displacive crystals

- bedding and contacts: one bed 2-3 $\mathrm{cm}$ thick of mud

- diagenetic features: sylvite veins,bottom growth gypsum pseudomorphs

Displacive Halite with Varying Amounts of Mud

- color: chocolate brown mud, brown halite

- sedimentary characteristics: 5-10\% mud, small displacive crystals

- bedding and contacts: no evident bedding

- diagenetic features: small to medium sized sylvite veins, large dissolution pipes filled with clear halite

Mixed Bedded and Displacive Halite

- color: chocolate brown and grey mud, dark brown halite

- sedimentary characteristics: 30-35\% mud mainly in mud drapes, cubic displacive halite crystals

- bedding and contacts: small beds of crystals with mud drapes

- diagenetic features: reduction? mud drapes

Bedded Halite

- color: chocolate brown/grey mud, brown halite

- sedimentary characteristics: $20 \%$ mud mainly found in mud drapes, rare displacive halite crystals, entire unit becomes slightly more orange as you move up

- bedding and contacts: beds are defined by crystal's bottom growth structure

- diagenetic features: dissolution pipes filled with clear halite,reduction? in mud drapes

Displacive Halite that is Mud Rich

- color:mud $10 \mathrm{R} 2.5 / 2$ and grey, halite is brown to pink

- sedimentary characteristics: $80 \%$ mud, mud is massive, cubic displacive halite crystals

- bedding and contacts: no bedding seen

- diagenetic features:reduction? in the mud

Bedded Halite

- color: mixed chocolate brown, brown and pink halite 
- sedimentary characteristics: the abundance of mud increases as you move up from $10-30 \%$, mud is found in mud drapes

- bedding and contacts: beds defined by upward bottom growth crystals

- diagenetic features:reduction?in mud

\begin{tabular}{|c|c|c|}
\hline & & $\begin{array}{l}\text { - color:warm chocolate brown mud, brown halite } \\
\text { - } \text { bedimentary characteristics:70-80\% mud, cubic displacive halite crystals } \\
\text { - diagenetic features:dissolution pipes filled with clear halite, sylvite veins }\end{array}$ \\
\hline 123 & 799.3-797 & $\begin{array}{l}\text { Bedded Halite } \\
\text { - color:mud is } 10 \mathrm{R} 2.5 / 2 \text { and grey, halite is dark brown } \\
\text { - } \text { sedimentary characteristics: } 15-20 \% \text { mud, mud drapes } \\
\text { - } \text { bedding and contacts:same as unit } 121 \\
\text { diagenetic features: sylvite veins }\end{array}$ \\
\hline 124 & 797-796.4 & $\begin{array}{l}\text { Displacive Halite that is Mud Rich } \\
\text { - color: same as } 122 \\
\text { - } \text { sedimentary characteristics: } 50 \% \text { mud } \\
\text { - diagenetic features: sylvite veins, dissolution pipes filled with clear halite }\end{array}$ \\
\hline 125 & 796.4-795.3 & $\begin{array}{l}\text { Bedded Halite } \\
\text { - color: chocolate brown mud, dark brown halite } \\
\text { - sedimentary characteristics: } 10 \% \text { mud found in small mud drapes, upward } \\
\text { - bewth halite crystals } \\
\text { - diagenetic features: reduction? in mud }\end{array}$ \\
\hline 126 & 795.3-794.7 & $\begin{array}{l}\text { Displacive Halite } \\
\text { - color: same as unit } 125 \\
\text { - sedimentary characteristics: well sorted mud, cubic displacive halite } \\
\text { - crystals } \\
\text { - diagenetic features:large sylvite veins, dissolution pipes filled with clear } \\
\text { halite }\end{array}$ \\
\hline 127 & 794.7-794.1 & $\begin{array}{l}\text { Bedded Halite } \\
\text { - color:same as unit } 125 \\
\text { - } \text { sedimentary characteristics: } 5-10 \% \text { mud found in mud drapes,sharp } \\
\text { contact with unit } 126 \\
\text { - bedding and contacts: well defined beds from halite growth } \\
\text { diagenetic features: same as } 126\end{array}$ \\
\hline 128 & 794.1-793.9 & $\begin{array}{l}\text { Displacive Halite } \\
\text { - color:same as unit } 125 \\
\text { - sedimentary characteristics: well sorted mud, cubic displacive halite } \\
\text { crystals } \\
\text { - bedding and contacts: no bedding seen } \\
\text { - diagenetic features: very large sylvite veins }\end{array}$ \\
\hline 129 & 793.9-791.6 & $\begin{array}{l}\text { Bedded Halite } \\
\text { - color: same as unit } 125 \\
\text { - sedimentary characteristics: mud drapes and upward growth halite } \\
\text { crystals } \\
\text { - bedding and contacts: same as } 127 \\
\text { - diagenetic features: reduction? in mud }\end{array}$ \\
\hline 130 & 791 & Missing Core \\
\hline
\end{tabular}


Eichenlaub, L.A., 2016

131

132

135

136

137

138
$780.7-780.2$

$780.2-779.5$

$779.5-778.5$

789.9-782

$782-780.7$

$780.2-779.5$

79.5-778.5

778.5-778.3

778.3-773.6

773.6-771.4

771.4-770.9

770.9-769.8

Bedded Halite

- color: orangeish brown mud,brown halite

- sedimentary characteristics: small to medium sized bottom growth halite crystals

- bedding and contacts: sharp bedding boundaries with the other units

- diagenetic features: sylvite veins, dissolution pipes filled with clear halite, pseudomorph gypsum splays

Displacive Halite that is Mud Rich

- color:mud is 10R 2.5/1, $10 \mathrm{R} 3 / 10 \mathrm{~B}$ and Gley 2 5/5RB, halite is brown

- sedimentary characteristics:60\% mud, displacive halite crystals

- bedding and contacts: some bedding seen in the mud, sharp contact with unit 131

- diagenetic features:reduction gradient? in mud, sylvite veins

Bedded Halite

- color: bright orange color found in spots it he halite $10 \mathrm{R} 6 / 8$, brown halite, brown mud

- sedimentary characteristics: 5-10\% mud, same as 131

- bedding and contacts: same as 131

- diagenetic features: reduction? in mud

Displacive Halite

- color: same as 132

- sedimentary characteristics: same as 132

- bedding and contacts:no bedding seen

- diagenetic features: sylvite veins, reduction? in mud

Bedded Halite

- color: same as 133

- sedimentary characteristics: same as 131

- bedding and contacts: same as 131

- diagenetic features: same as 131

Mixed Bedded and Displacive Halite

- color: same as 133

- sedimentary characteristics: common displacive halite crystals, bottom growth halite crystals

- bedding and contacts:bedding is evident in crystal shape

- diagenetic features: dissolution pipes filled with clear halite, reduction? in mud, pseudomorph gypsum crystals

Mixed Bedded and Displacive Halite

- color: same as unit 133

- sedimentary characteristics: $10-15 \%$ mud, common halite displacive crystals found suspended in mud

- bedding and contacts: defined beds from crystal size and shape

- diagenetic features: reduction? in mud drapes, sylvite veins, gypsum pseudomorph splays

Missing Core

Mixed Bedded and Displacive Halite

- color: mud is chocolate brown, halite is brown

- sedimentary characteristics:5-10\% mud found in mud drapes

- bedding and contacts: same as unit 137

- diagenetic features: reduction? in mud

Bedded Halite

- color: chocolate brown mud, brown halite 
- sedimentary characteristics: 5-10\% mud found in mud drapes and mud clasts

- bedding and contacts: well defined beds from crystal shape and color

- diagenetic features:rare reduction? found in mud

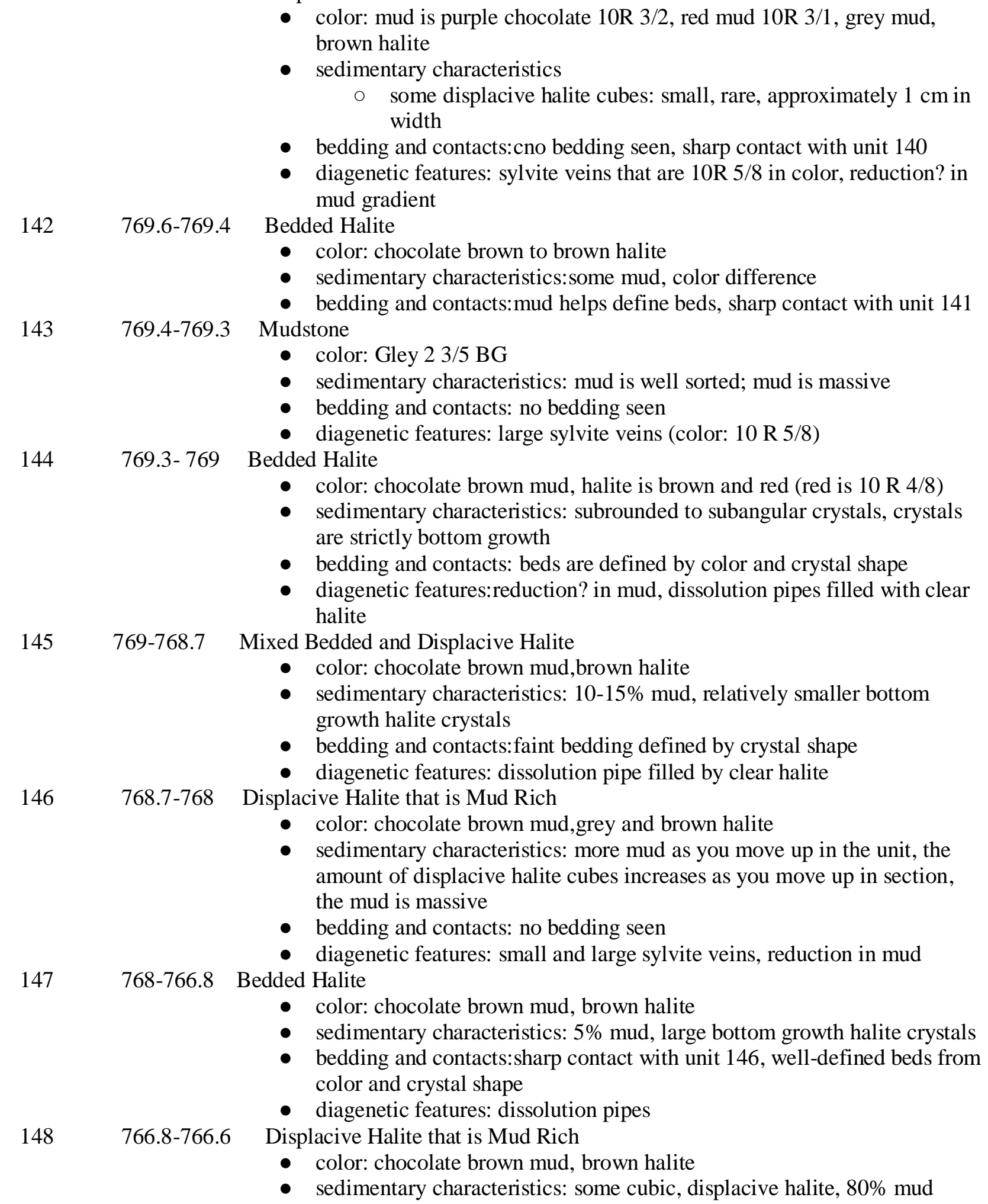


- bedding and contacts: sharp contact with unit 147 , no bedding with mud or halite

- diagenetic features: medium sized sylvite veins

Bedded Halite

- color: chocolate brown and red mud, brown halite

- sedimentary characteristics: $20 \%$ mud found in mud drapes, bottom growth halite crystals

- bedding and contacts: very well-defined bedding from color and crystal shape

- diagenetic features: reduction? in mud

150 766.1-766 Displacive Halite that is Mud Rich

- color: grey and chocolate brown mud, brown halite

- sedimentary characteristics: common displacive halite cubes, $80 \%$ mud

- bedding and contacts: no bedding in the mud, layers of displacive cubes (would grow on a plane. Is this bedding?)

- diagenetic features: medium sized sylvite veins, reduction? in mud

$151 \quad 766-765.3 \quad$ Bedded Halite

- color: brown halite,chocolate brown and grey mud

- sedimentary characteristics: 5-10\% mud, bottom growth crystals are subrounded

- bedding and contacts:bedding formed from crystal shape

- diagenetic features:dissolution pipes, reduction? in mud

152 765.3-765 Mixed Bedded and Displacive Halite

- color: grey mud, brown halite

- sedimentary characteristics: 5-10\% mud

- bedding and contacts: faint bedding

- diagenetic features: sylvite veins

$153 \quad 765-764.3$ Bedded Halite

- color: grey mud, brown halite

- sedimentary characteristics: 5-10\% mud, large pink/brown colored halite crystals, grey mud drapes

- bedding and contacts: evident bedding, sharp contact boundary with unit 154

- diagenetic features: dissolution pipes, reduction? of mud

154 764.3-764.1 Displacive Halite that is Mud Rich

- color: chocolate brown color of mud,brown clear halite

- sedimentary characteristics: common displacive halite crystals, $80-90 \%$ mud

- bedding and contacts: sharp lower contact with unit 153

- diagenetic features: large sylvite veins

155 764.1-762.5 Mixed Bedded and Displacive Halite

- color: chocolate brown and grey mud, brown and pink halite

- sedimentary characteristics: $20 \%$ mud, distinct cubic halite crystals in mud, bottom growth halite crystals

- bedding and contacts: bedding formed from crystal shape and mud drapes

- diagenetic features: reduction? in mud seen in color, dissolution pipes filled with halite, sylvite veins

$156 \quad 762.5-762.45$ Displacive Halite that is Mud Rich

- color: chocolate brown and grey mud

- sedimentary characteristics: $90 \%$ mud, rare displacive halite crystals 
Eichenlaub, L.A., 2016

$759.5-759.2$

161

162
$762.45-760.9$

- bedding and contacts: no bedding seen

- diagenetic features: sylvite veins, reduction? in mud

Bedded Halite

- color: chocolate brown and grey mud,brown halite

- bedding and contacts: beds from color and shape, $2-3 \mathrm{~cm}$ thick beds of mud

- diagenetic features:reduction in mud, thin sylvite veins, dissolution pipes

760.9-760 Mixed Bedded and Displacive Halite

- color: chocolate brown and grey mud, brown/pink halite

- sedimentary characteristics: displacive halite cubes mixed in with bedding, $30 \%$ mud

- bedding and contacts: well-defined beds from bottom growth crystals

- diagenetic features: reduction? in mud, large dissolution pipe

760-759.5 Displacive Halite that is Mud Rich

- color: dark grey to chocolate brown mud, brown halite

- sedimentary characteristics: cubic, displacive halite crystals

- bedding and contacts: bedding evident from halite growth

- diagenetic features: thick vein of sylvite, reduction? in mud

Bedded Halite

- color: chocolate brown mud, clear brown halite

- sedimentary characteristics: rare mud ( $5-10 \%)$

- bedding and contacts: bedding evident from halite color and crystal shape

- diagenetic features: dissolution pits, grey mud, possible reduction?

759.2-758.2 Displacive Halite that is Mud Rich

- color: chocolate brown mud, clear brown halite

- sedimentary characteristics: high mud content, subrounded, cubic halite crystals

- bedding and contacts: maybe some bedding in mud based on coloration

- diagenetic features: thin sylvite veins, reduction? in mud

758.2-757.9 Mixed Bedded and Displacive Halite

- color: chocolate brown and grey mud,brown halite

- sedimentary characteristics: subrounded, displacive, cubic halite; some mud

- bedding and contacts: faint traces of bedding in coloration

- diagenetic features: reduction? in mud, thin sylvite veins

757.9-756.9 Bedded Halite

- color: same as unit 162

- sedimentary characteristics: very large halite crystals,rare to some mud

- bedding and contacts:bedding seen by color and crystal shape

- diagenetic features: dissolution pipes filled by clear halite

756.9-756.2 Mixed Bedded and Displacive Halite

- color: same as unit 162

- sedimentary characteristics: some mud

- bedding and contacts: faint traces of beds

- diagenetic features:a large amount of large dissolution pits and pipes, thin sylvite veins

756.2-755.9 Bedded Halite

- color: same color as unit 162

- sedimentary characteristics: smallto medium halite crystals that are subangular in shape, rare mud 
Eichenlaub, L.A., 2016

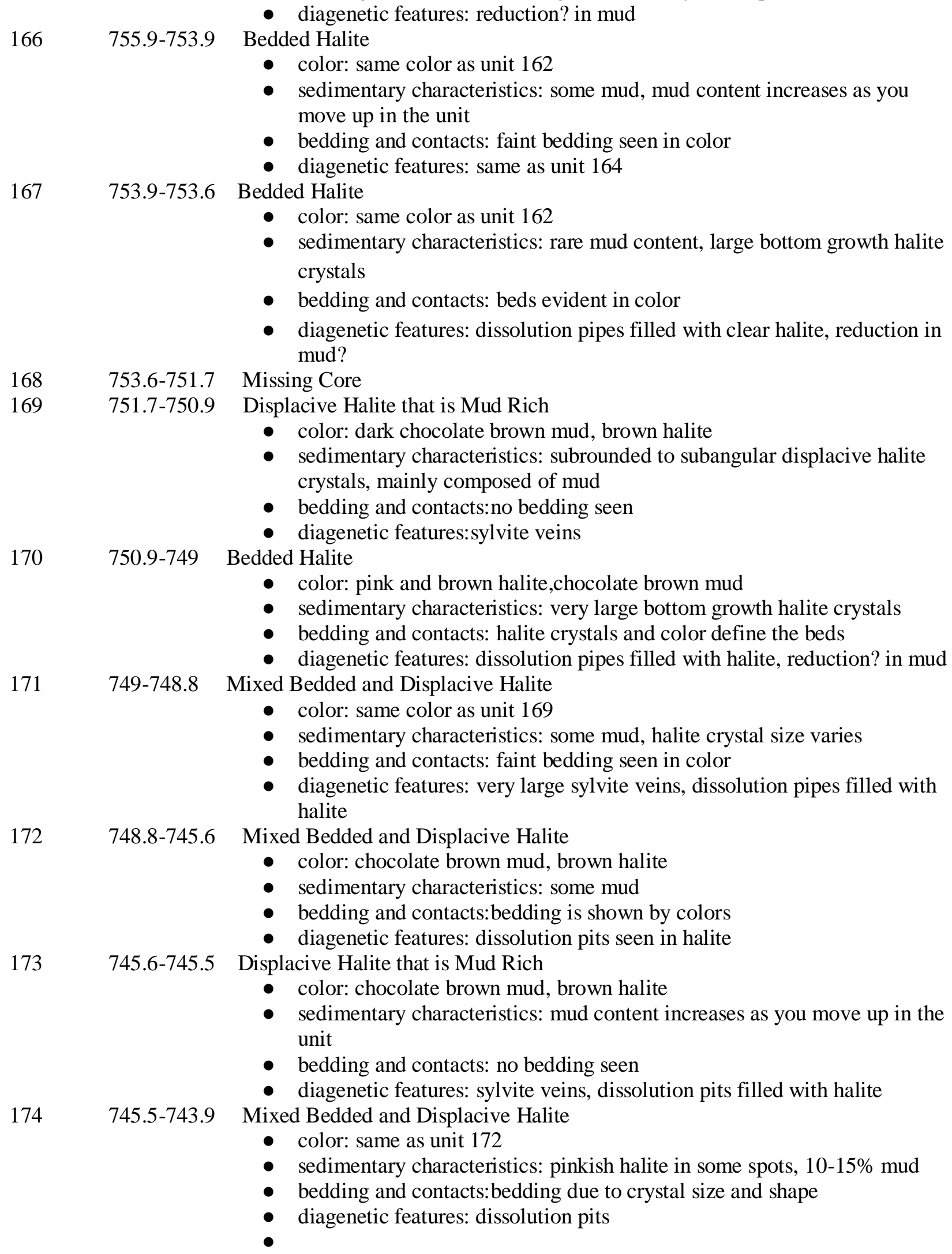

- bedding and contacts: bedding evident in crystal shape and color

- diagenetic features: reduction? in mud 
Eichenlaub, L.A., 2016

175

176

177

178

179

180

181

182

743.9-743.1 Bedded Halite

- color: mainly chocolate brown mud with some grey mud, brown halite

- sedimentary characteristics: rare to some mud

- bedding and contacts: bedding defined by crystal color

- diagenetic features: dissolution pipes filled with halite, sylvite veins

743.1-742.5 Mixed Bedded and Displacive Halite

- color: Gley 2 4/5GB and brown/red mud, brown halite

- sedimentary characteristics: some mud, a mix of halite crystal sizes

- bedding and contacts:faint bedding beds found due to crystal type (ex. displacive or bedded)

- diagenetic features:dissolution pits filled with halite

742.5-741.8 Bedded Halite

- color: chocolate brown mud, brown halite

- sedimentary characteristics: rare mud

- bedding and contacts: bedding evident through color change

- diagenetic features: dissolution pits filled with halite

741.8-741.7 Displacive Halite that is Mud Rich

- color: same as unit 177

- sedimentary characteristics: mostly mud, some displacive, cubic halite crystals

- bedding and contacts: no distinct bedding seen

- diagenetic features: large sylvite veins

741.7-739.9 Mixed Bedded and Displacive Halite

- color: chocolate brown mud, brown halite

- sedimentary characteristics: varying crystal size, $30 \%$ mud, mud content increases as you move up in section

- bedding and contacts: faint bedding from coloration

- diagenetic features: dissolution pipes filled with halite

739.9-739.2 Bedded Halite

- color: chocolate brown and grey mud, pink and brown halite

- sedimentary characteristics: very large bottom growth halite crystals with large mud clasts in the center of the crystals

- bedding and contacts: evident bedding from crystal shape

- diagenetic features: reduction? seen in mud

739.2-737.6 Mixed Bedded and Displacive Halite

- color: same as 179

- sedimentary characteristics:30-40\% mud, subangular halite crystals

- bedding and contacts: bedding defined by crystal shapes

- diagenetic features: reduction? in mud, dissolution pits

737.6-735.9 Missing Core

735.9-734.3 Mudstone

- color: mud is red/brown 2.5 Yr 3/3 and Gley 2 5/5B

- sedimentary characteristics: well-sorted, rare displacive halite crystals, mud is massive

- bedding and contacts:no bedding seen

- diagenetic features:large sylvite veins that are $7 \mathrm{~cm}$ thick, reduction spots? that could be roots?

734.3-733.4 Missing Core

733.4-732.4 Displacive Halite that is Mud Rich

- color: chocolate brown mud, brown halite 
- sedimentary characteristics: 50-60\% mud; cubic, displacive halite crystals

- bedding and contacts: no bedding seen

- diagenetic features: dissolution pipes filled with clear halite

- color: mud is red/brown $2.5 \mathrm{YR} 3 / 3,11 \mathrm{~cm}$ thick bed of grey mudstone

- sedimentary characteristics: ped-like sed textures, slickens, rare displacive halite crystals

- bedding and contacts: no bedding seen

- diagenetic features: sylvite veins, dissolution pipes filled with halite

$187 \quad 727-725.2 \quad$ Missing Core

$188 \quad 725.2-723.3$ Displacive Halite that is Mud Rich

- color: same as unit 185

- sedimentary characteristics: cubic displacive halite crystals, very high clay content, $60 \%$ mud

- bedding and contacts: same as unit 185

- diagenetic features: reduction? seen in mud

Mudstone

- color: warm, chocolate brown mud

- sedimentary characteristics: mud is well sorted and massive

- bedding and contacts: no bedding seen

- diagenetic features: large dissolution pipes filled with halite, medium sized (thickness) sylvite veins that are $50 \mathrm{~cm}$ long

190 722.6-722.3 Displacive Halite

- color: chocolate brown mud, brown halite

- sedimentary characteristics: $70 \%$ mud, cubic, displacive halite crystals

- bedding and contacts:no bedding seen

- diagenetic features:small sylvite veins

- color: warm chocolate brown mud

- sedimentary characteristics: same as unit 189

- bedding and contacts: same as unit 189

- diagenetic features: sylvite veins

192 721.4-719.4 Missing Core

193 719.4-718.9 Displacive Halite that is Mud Rich

- color: same as unit 189

- sedimentary characteristics: $90 \%$ mud with some cubic displacive halite crystals

- bedding and contacts: no bedding seen

$194 \quad 718.9-699$

Displacive Halite

- color: chocolate brown and grey mud

- sedimentary characteristics: very large displacive halite crystals with mud clasts, mud content decreases as you move up section

- bedding and contacts: no bedding seen

- diagenetic features: reduction? in mud, dissolution pits filled with clear halite

195 699-695.6 Missing Core

196 695.6-688.4 Displacive Halite

- color: chocolate brown and grey mud 
- sedimentary characteristics: very large displacive halite crystals with mud clasts, mud content decreases as you move up section

- bedding and contacts: no bedding seen

- diagenetic features: reduction? in mud, dissolution pits filled with clear halite

688.4-688.2 Displacive Halite that is Mud Rich

- color: chocolate brown mud, clear brown halite

- sedimentary characteristics: large halite crystals, $15-20 \%$ mud

- bedding and contacts: no bedding seen

- diagenetic features: some grey reduction? spots, dissolution pits and pipes

198 688.2-686 Displacive Halite that is Mud Rich

- color: chocolate brown mud, rare areas of grey mud

- sedimentary characteristics: $10-15 \%$ mud, subangular displacive halite crystals

- bedding and contacts: no bedding seen

- diagenetic features: sylvite veins

199 686-682.1 Igneous Rock

- color: black on fresh surface Gley $12.5 / \mathrm{N}$, green on weathered surface Gley $15 / 5 \mathrm{GY}$

- sedimentary characteristics: aphanitic,looks like basalt, but does not feel as dense

- bedding and contacts: N/A

- diagenetic features: halite veins, green weathering

200 682.1-681.1 Mixed Bedded and Displacive Halite

- color: mud is Gley $12.5 / \mathrm{N}$, dark brown and clear halite

- sedimentary characteristics: $20-30 \%$ mud, mud is found in clasts and beds

- bedding and contacts: sharp contact with unit 199

- diagenetic features: dissolution pipes filled with clear halite

201 681.1-680 Displacive Halite

- color: chocolate brown mud, brown halite

- sedimentary characteristics: large cubic halite crystals $\sim 1 \mathrm{~cm}$ in length

- bedding and contacts: no bedding seen

- diagenetic features: some dissolution pits filled with pink halite crystals, reduction? in mud

202 680-679 Mudstone

- color: Gley 2 4/10 G mud, chocolate brown mud

- sedimentary characteristics: high clay content, ped textures, soil slicks

- bedding and contacts: no bedding seen

- diagenetic features: sylvite veins, reduction? in mud

203 679-678.6 Displacive Halite

- color: chocolate brown mud, brown halite

- sedimentary characteristics: large displacive halite crystals that are cubic and subangular, $20 \%$ mud

- bedding and contacts: no bedding seen

- diagenetic features: dissolution pits, sylvite veins

204 678.6-676.1 Bedded Halite

- color: chocolate brown mud, clear brown halite

- sedimentary characteristics: rare displacive halite crystals

- bedding and contacts: beds are defined by crystal shape 
Eichenlaub, L.A., 2016

- diagenetic features: some dissolution pits, reddish color found underneath a salt bed

676.1-673.7 Mixed Bedded and Displacive Halite

- color: chocolate brown mud, clear brown halite

- sedimentary characteristics: subangular cubic halite crystals

- bedding and contacts: bedding defined by crystal shape

- diagenetic features: some dissolution pits

206 673.7-666.3 Displacive Halite that is Mud Rich

- color: chocolate brown mud and grey mud, clear brown halite

- sedimentary characteristics: large subangular, cubic halite crystals,10$15 \%$ mud

- bedding and contacts: no bedding seen

- diagenetic features: sylvite veins, dissolution pits

207 666.3-662.3 Missing Core

208 662.3-660 Mixed Bedded and Displacive Halite

- color: chocolate brown mud, clear brown halite

- sedimentary characteristics: crystal size varies, 5-10\% mud

- bedding and contacts:some bedding from gypsum pseudomorph crystals

- diagenetic features: gypsum pseudomorph crystals, dissolution pits filled with halite, reduction in mud?

209 660-659.5 Bedded Halite

- color: chocolate brown mud, brown halite

- sedimentary characteristics: $5 \%$ mud

- bedding and contacts: beds defined from crystal size and shape

- diagenetic features: pseudomorph gypsum crystals, dissolution pipes filled with halite

210 659.5-658.2 Displacive Halite

- color: same as unit 208

- sedimentary characteristics: $5 \%$ mud, large, subangular, displacive halite cubes, few mud drapes

- bedding and contacts: no true bedding

- diagenetic features: dissolution pipes filled with halite

$211 \quad 658.2-658$ Bedded Halite

- color: chocolate brown mud, brown clear halite

- sedimentary characteristics: 5-10\% mud, gorgeous salt crystals

- bedding and contacts: evident bedding defined by halite crystal size and shape, sharp contact with unit 210

212 658-656 Mixed Bedded and Displacive Halite

- color: same as unit 208

- sedimentary characteristics: $15 \%$ mud, large mud clasts, subangular halite crystals

- bedding and contacts:beds formed from color and crystal shape

- diagenetic features:reduction? in mud

213 656-653.7 Mixed Bedded and Displacive Halite

- color: chocolate brown and grey mud

- sedimentary characteristics: large cubic halite crystals, 20-25\% mud

- bedding and contacts: evident contact with unit 212 shown by a change of color and appearance of sylvite veins

- diagenetic features: sylvite veins, reduction? in mud 
Eichenlaub, L.A., 2016

214

215

651.4-647.83

653.7-651.4 Mixed Bedded and Displacive Halite

- color: chocolate brown and grey mud, clear and brown halite

- sedimentary characteristics: subangular halite crystals, 5\% mud

- bedding and contacts: bedding evident from crystal growth and color

- diagenetic features: dissolution pipes filled with clear halite

Displacive Halite

- color: chocolate brown and blue/grey mud, mud becomes more red as you move up section (2.5 YR 3/4)

- sedimentary characteristics: $10 \%$ mud, very small mud clasts with rare large mud clasts, large cubic displacive crystals, mud clasts become larger as you move up section

- bedding and contacts: no bedding seen

- diagenetic features: reduction of mud? dissolution pipes filled with clear halite

216 647.83-646.8 Mixed Bedded and Displacive Halite

- color: Gley $22.5 / 5$ GB mud and chocolate brown mud

- sedimentary characteristics: 5-10\% mud, large cubic halite crystals

- bedding and contacts: beds evident due to crystal growth,

- diagenetic features: dissolution pits,little sylvite veins

217 646.8-645.5 Displacive Halite

- color: chocolate brown mud, brown clear halite, some areas of grey mud near the bottom of the section

- bedding and contacts: no bedding seen

- diagenetic features: dissolution pits, sylvite veins

218 645.5-643 Missing Core

219 643-642.3 Displacive Halite

- color: chocolate brown mud, dark, clear, grey halite

- sedimentary characteristics: large halite crystals that are subangular, $10 \%$ mud

- bedding and contacts: no bedding seen

- diagenetic features: dissolution pits, few sylvite veins

220 642.3-641.7 Mixed Bedded and Displacive Halite

- color: chocolate brown mud with various spots of reddish brown, brown halite

- $\quad$ sedimentary characteristics: bottom growth halite crystals, cubic displacive halite crystals, 5-10\% mud

- bedding and contacts: bedding formed from bottom growth crystals and mud

- diagenetic features: dissolution pipes and pits filled with halite, sylvite veins, muddier sections

$641.7-633.5$

Displacive Halite

- color: chocolate brown with grey mud, brown halite

- sedimentary characteristics: angular mud clasts, large cubic, displacive halite crystals, mud abundance varies throughout

- bedding and contacts: no bedding seen

- diagenetic features:dissolution pits filled with clear halite, medium sized sylvite veins as you move up in section

Displacive Halite that is Mud Rich

- color: chocolate brown mud,

- halite dissolved due to lack of plastic

- sedimentary characteristics: 50-60\% mud 
Eichenlaub, L.A., 2016

633.16-629.8 Displacive Halite

- bedding and contacts: no bedding seen

- diagenetic features: large sylvite veins

- color: chocolate brown with rare grey mud, halite is dark brown

- sedimentary characteristics: small mud clasts, small halite crystals, mud abundance varies

- bedding and contacts: no bedding seen

- diagenetic features: sylvite veins, dissolution pits

629.8-629.7 Bedded Halite

- color: clear to pink halite

- sedimentary characteristics: very large halite crystals, no mud

- bedding and contacts: sharp contact with 223 and 225, bedding formed from crystal shape

225 629.7-627 Displacive Halite

- color: same as unit 221 with some added red and brown

- sedimentary characteristics: mud clasts, $15-20 \%$ mud, cubic displacive crystals

- bedding and contacts: sharp contact with 224 , no bedding seen

- diagenetic features: potentially some dissolution pipes and pits

226 627-625.1 Missing Core

227 625.1-604.8 Displacive Halite

- color: chocolate brown mud, brown halite

- sedimentary characteristics: varying amounts of mud, mud clasts, cubic halite crystals more salt rich at 615.4 meters

- bedding and contacts: no bedding seen

- diagenetic features:dissolution pits filled with halite and mud

228 604.8-604 Mudstone

- color: chocolate brown and grey mud, brown halite

- sedimentary characteristics: rare displacive halite crystals, breaks apart like peds

- bedding and contacts:no bedding seen

- diagenetic features:thin to medium thickness sylvite veins, reduction spots?

229 604-581.1 Displacive Halite

- color: same as unit 227

- sedimentary characteristics: 20-30\% mud, cubic displacive halite crystals, subangular mud clasts, mud varies throughout section

- bedding and contacts: no bedding seen

- diagenetic features:dissolution pipes are filled with clear halite crystals

$230 \quad 581.1-569.6$ Mudstone

- color: 2.5 YR 3/2 brown with reddish tint

- sedimentary characteristics: $90 \%$ mud, medium halite crystals, soil slicks in core

- bedding and contacts: no bedding seen

- diagenetic features: sylvite veins, color changes to grey in some sections, potential reduction?

$231 \quad 569.6-502.2 \quad$ Mudstone

- color: brown with red tint, same as unit 230

- sedimentary characteristics: $100 \%$ mud, soil slicks, breaks apart like crumbling peds

- bedding and contacts:no bedding seen 
Eichenlaub, L.A., 2016

fossil?, potential gypsum crystals and vein

- diagenetic features: gypsum efflorescence, definite reduction spots, root

- color: host rock is 2.5 YR 4/3, reduction spots are Gley $26 / 10 B$

- sedimentary characteristics: silt sized grains, wavy discontinuous grey lamina

- bedding and contacts: gradual contact change with unit 231, grey mud bed that's $6 \mathrm{~cm}$ thick

501.82-501.28 Siltstone

- diagenetic features: circular reduction spots

- color: grey Gley $17 / 10 Y$

- sedimentary characteristics: silt sized grains, wavy discontinuous red lamina 2.5 YR 4/4

- bedding and contacts: sharp contact with 232 and 234

- diagenetic features: reduction zone?

$234 \quad 501.28-492.7 \quad$ Siltstone

- color: same as 232

- sedimentary characteristics: relatively massive, soil slicks, ripples?

- bedding and contacts: sharp contact with 233

- diagenetic features: reduction spots

$235 \quad 492.7-491.2 \quad$ Sandstone

- color: Gley 2 8/5 PB

- sedimentary characteristics: fine grain quartz grains, 90\% quartz grains, well cemented, massive

- bedding and contacts: no bedding seen

- diagenetic features: gypsum efflorescence

$236 \quad$ 491.2-486.6 Siltstone

- color: $10 \mathrm{R} 4 / 6$

- sedimentary characteristics: large, rare halite crystals floating in the host rock; massive siltstone

- bedding and contacts: no bedding

- diagenetic features: reduction spots that are Gley 2 5/10 GB

237 486.6-486.4 Sandstone

- color: same as unit 235

- sedimentary characteristics: same as unit 235

- bedding and contacts:same as unit 235

- diagenetic features: same as unit 235

Siltstone

- color: same as unit 236

- sedimentary characteristics: slickens

- bedding and contacts:no bedding seen

- diagenetic features: reduction spots

Mudstone

- color: Gley $25 / 10 \mathrm{G}$

- sedimentary characteristics: slickens, breaks apart in sheets

- bedding and contacts:no bedding seen

- diagenetic features:reddish color 10 R 3/3 from weathering?, deposited in thin, vertical red sheets in cracks in the core

$240 \quad 484.1-471 \quad$ Siltstone

- color: same as unit 236

- sedimentary characteristics: massive, well cemented 
Mudstone

- bedding and contacts: no bedding seen

- diagenetic features: reduction spots with a bullseye pattern, veins filled with a white, non-salty mineral

- color: host rock is Gley $13 / 5 \mathrm{G}$ with a green weathering

- sedimentary characteristics: maybe some chlorite? (Gley $17 / 5 \mathrm{GY}$ ), same mineral as unit 240, slickens, rare reddish brown specks

- bedding and contacts: no bedding seen

- color: Gley $12.5 / \mathrm{N}$, Gley $17 / \mathrm{N}$

- sedimentary characteristics: stringy black minerals, hornblende? (60\%), white chalk-like mineral (40\%)

- color: Gley 1 3/N

- sedimentary characteristics: greenish black host rock with black lineations, some quartz grains, streaks of brown

244 467.5-467.4 Mudstone

- bedding and contacts: no bedding

- color: 5 YR 4/3

- sedimentary characteristics: round clumps, breaks apart like blocky peds

- bedding and contacts: no bedding seen

- diagenetic features: reduction spots

245 467.4-464.8 Igneous Rock

- color: same as unit 243

- sedimentary characteristics: same as unit 243

- bedding and contacts: same as unit 243

$246 \quad 464.8-462.8$ Mudstone

- color: same as unit 244

- sedimentary characteristics: same as unit 244

- bedding and contacts: same as unit 244

247 462.8-456 Igneous Rock

- color: same as unit 243

- sedimentary characteristics: same as unit 243

- bedding and contacts: same as unit 243

248 456-455.7 Mudstone with Igneous Debris Clasts

- color: red 5 YR 4/3, grey Gley 1 5/10Y

- sedimentary characteristics: mud grades from grey to red, $80-90 \%$ mud, 10-20\% igneous debris

- bedding and contacts: sharp contact with units 247 and 249

- diagenetic features: reduction? in color gradient

$249 \quad$ 455.7-454.7 Igneous Rock

- color: same as unit 243

- sedimentary characteristics: same as unit 243

- bedding and contacts: same as unit 243

- color: same as unit 244

- sedimentary characteristics: 90-95\% mud, crumbles, some what "peddy"

- bedding and contacts: no bedding seen,sharp contact with 249

- diagenetic features: reduction? in mud 
Eichenlaub, L.A., 2016

- color: chocolate brown/red mud,somewhat purple in color

- sedimentary characteristics: slickens, very crumbly

- bedding and contacts: sharp contact with unit 250 , no bedding seen

- diagenetic features: reduction spots in mud

Mudstone

- color: glassy gypsum veins Gley $16 / 10 Y$, reduction spots Gley $17 / 5$ GY, red mud is 2.5 YR 4/3

- sedimentary characteristics: better cemented than unit 251

- bedding and contacts: no bedding seen

- diagenetic features: large gypsum veins, reduction spots

451.87-448.5 Mudstone

- color: same as unit 251

- sedimentary characteristics: same as unit 251

- bedding and contacts:same as unit 251

- diagenetic features: rare gypsum veins

448.5-447.8 Mudstone

- color: grey Gley $17 / 10$ Y

- sedimentary characteristics: slickens, some areas of red coloring, $100 \%$ mud

- bedding and contacts: sharp contacts with units 253 and 255 , no bedding seen

- diagenetic features: reduction? zone, gypsum veins

447.8-428.9 Mudstone

- color: same as unit 251

- sedimentary characteristics: same as unit 251

- bedding and contacts: same as unit 251

- diagenetic features: chalky white veins become more common around 444.4 meters

428.9-428.2 Mudstone

- color: Gley 2 6/5 BG

- sedimentary characteristics: well sorted, massive, breaks apart like peds

- bedding and contacts: sharp contact with units 255 and 257

- diagenetic features:gypsum veins

428.2-422.2 Mudstone

- color: same as unit 255

- sedimentary characteristics: same as unit 255

- bedding and contacts: same as unit 255

- diagenetic features: same as unit 255

422.2-421.63 Mudstone

- color: same as unit 256

- sedimentary characteristics: same as unit 256

- bedding and contacts: same as unit 256

- diagenetic features: same as unit 256

421.63-407.5 Mudstone

- color: same as unit 255

- sedimentary characteristics: same as unit 255

- bedding and contacts: same as unit 255

- diagenetic features:gypsum veins are very thick and long

407.5-404.6 Siltstone

- color: Gley 2 6/5 BG and 5 YR 5/4 
Eichenlaub, L.A., 2016

Appendix B:

Measured Section of the Carnduff 2 Core 
Eichenlaub, L.A., 2016

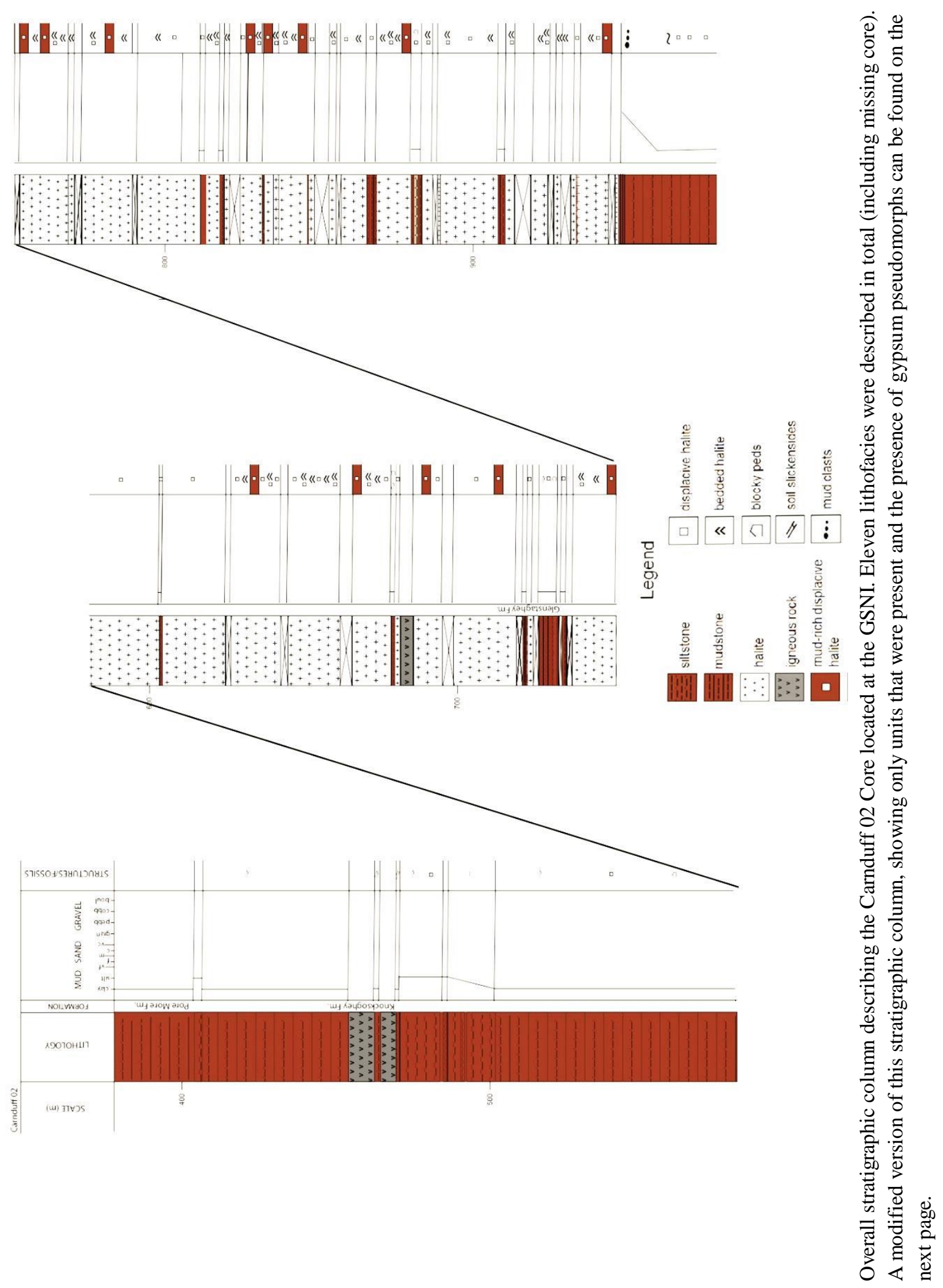




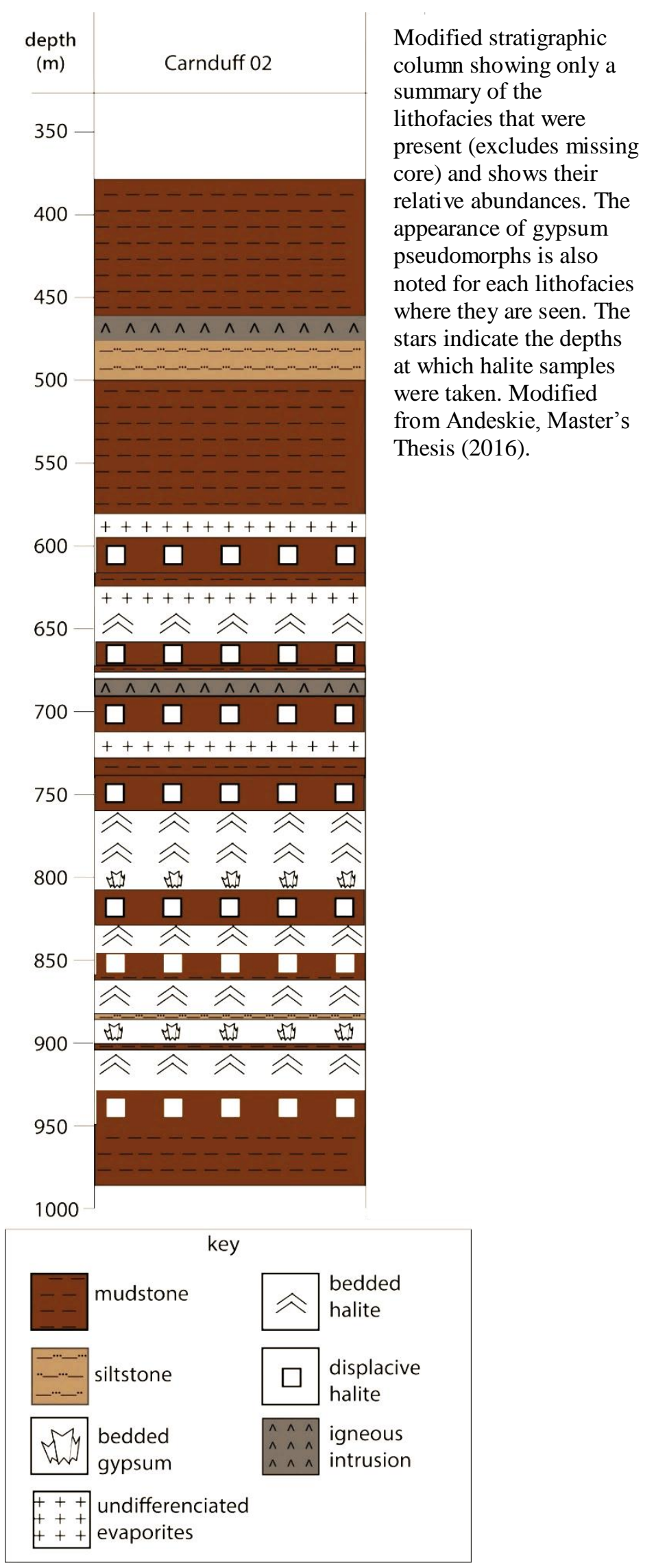


Eichenlaub, L.A., 2016

\section{Appendix C:}

\section{Fluid Inclusion Petrography}


Eichenlaub, L.A., 2016

Core: GESC Z (Carnduff 2)

$1 / 5 / 16$

depth: $659.5 \mathrm{~m}$



* Absolutely nothing seen in UV

* all liquird (except rim) inclusions 
Eichenlaub, L.A., 2016

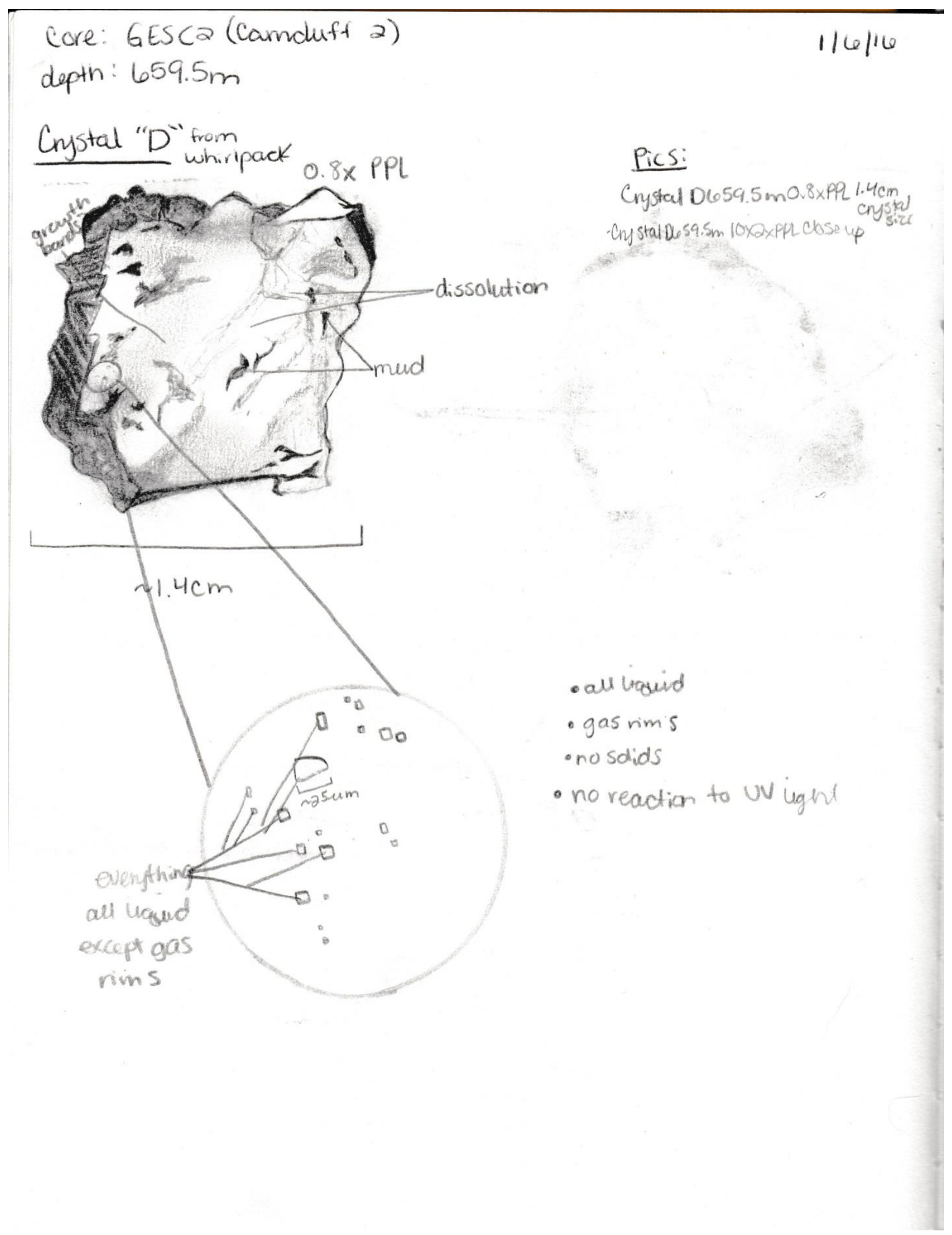


Eichenlaub, L.A., 2016

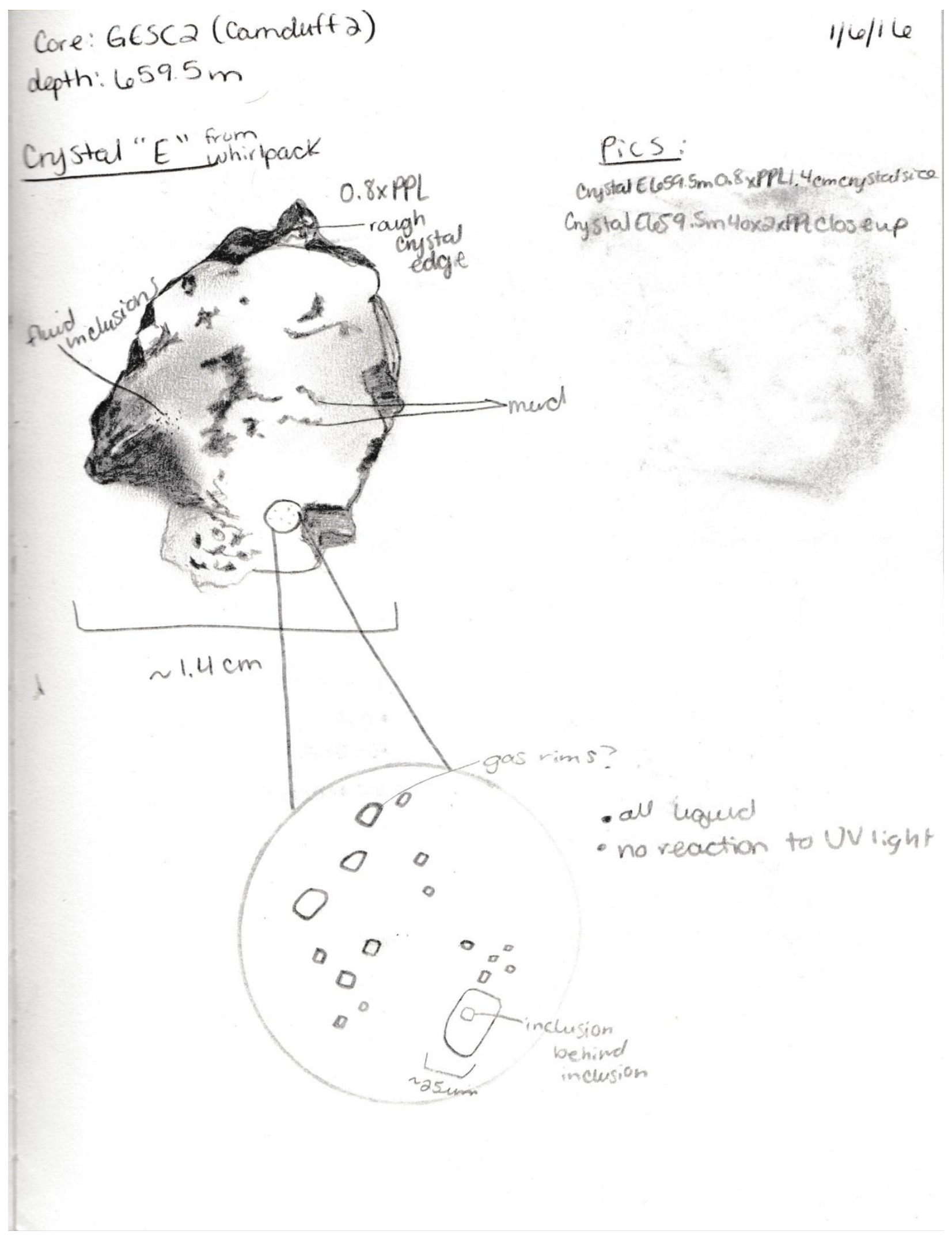


Eichenlaub, L.A., 2016

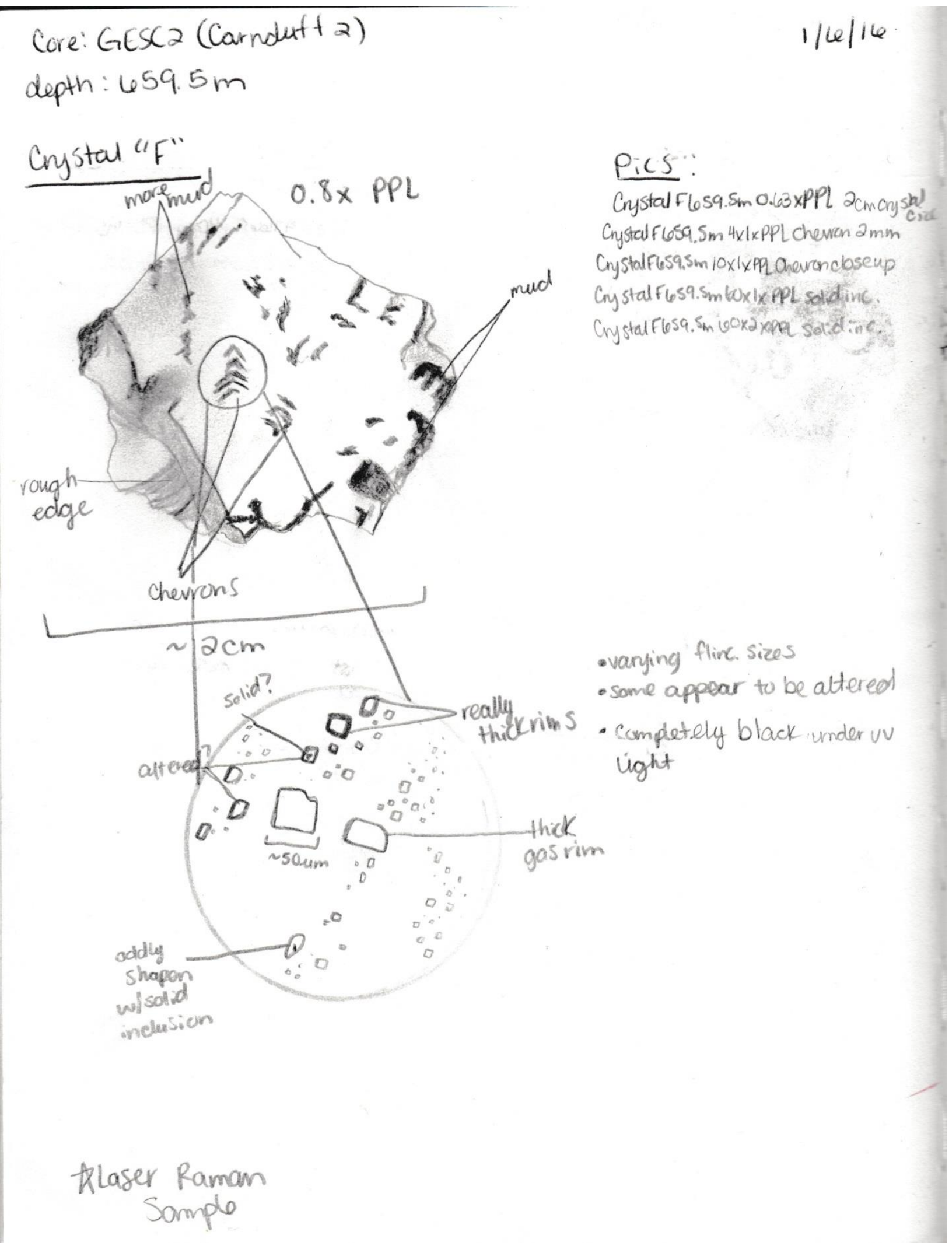


Eichenlaub, L.A., 2016

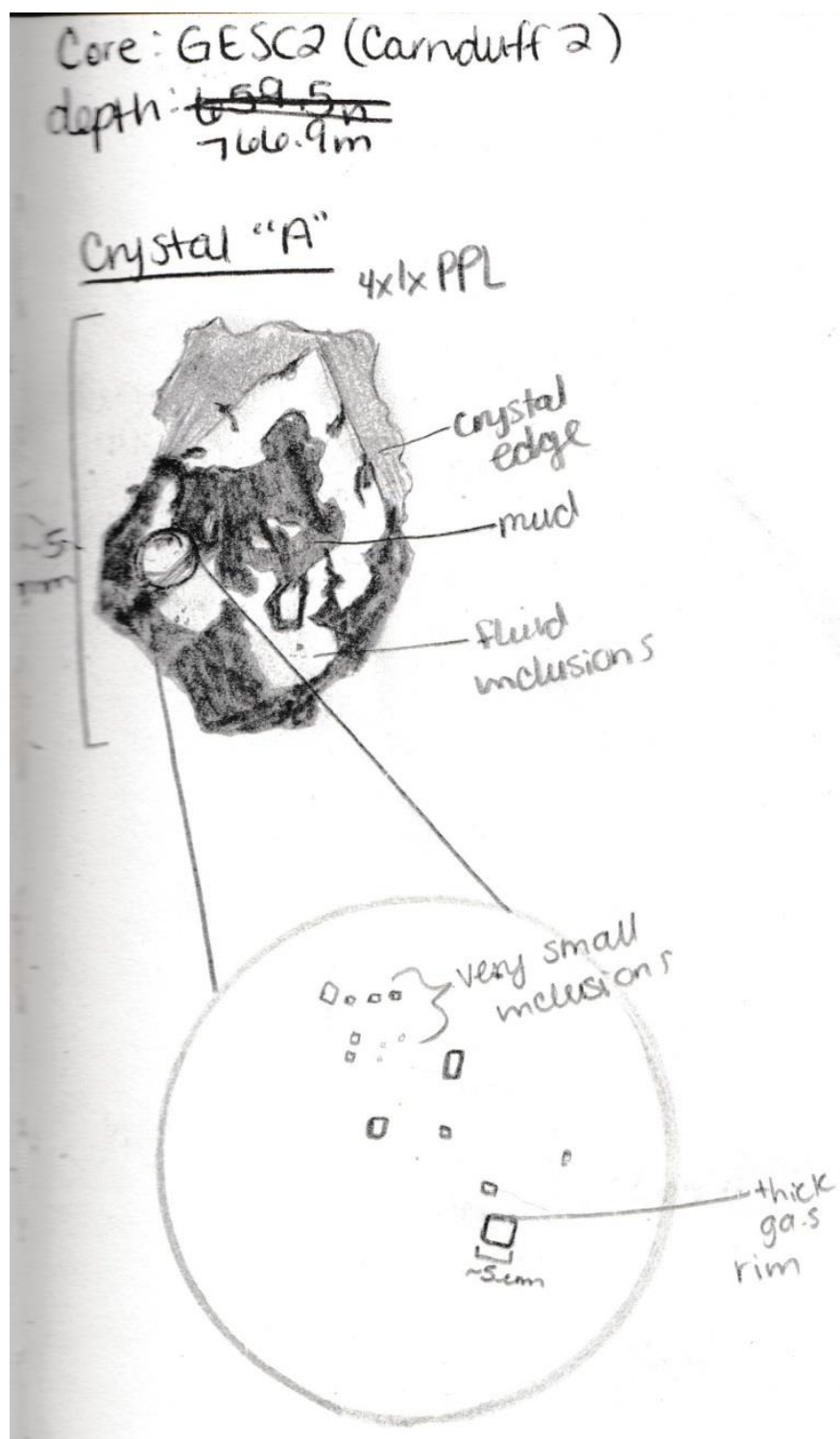

$1 / 7 / 16$

Pics:
* take whole on other micro

Ay statA 766 9n $40 x 2 x$ Pl close up

Constal A766.9 mo.5PPL $0.5 \mathrm{~cm}$

anstalsize

- all liquid (except $\mathrm{nm}$ )

- most flines are very

small < 5um

- Completely black under UV ught 
Core: GESC 2 (Carnduff 2 ) depth: $766.9 \mathrm{~m}$ Crystal "B"

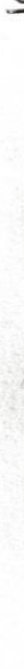



- non-muddy areas are full of

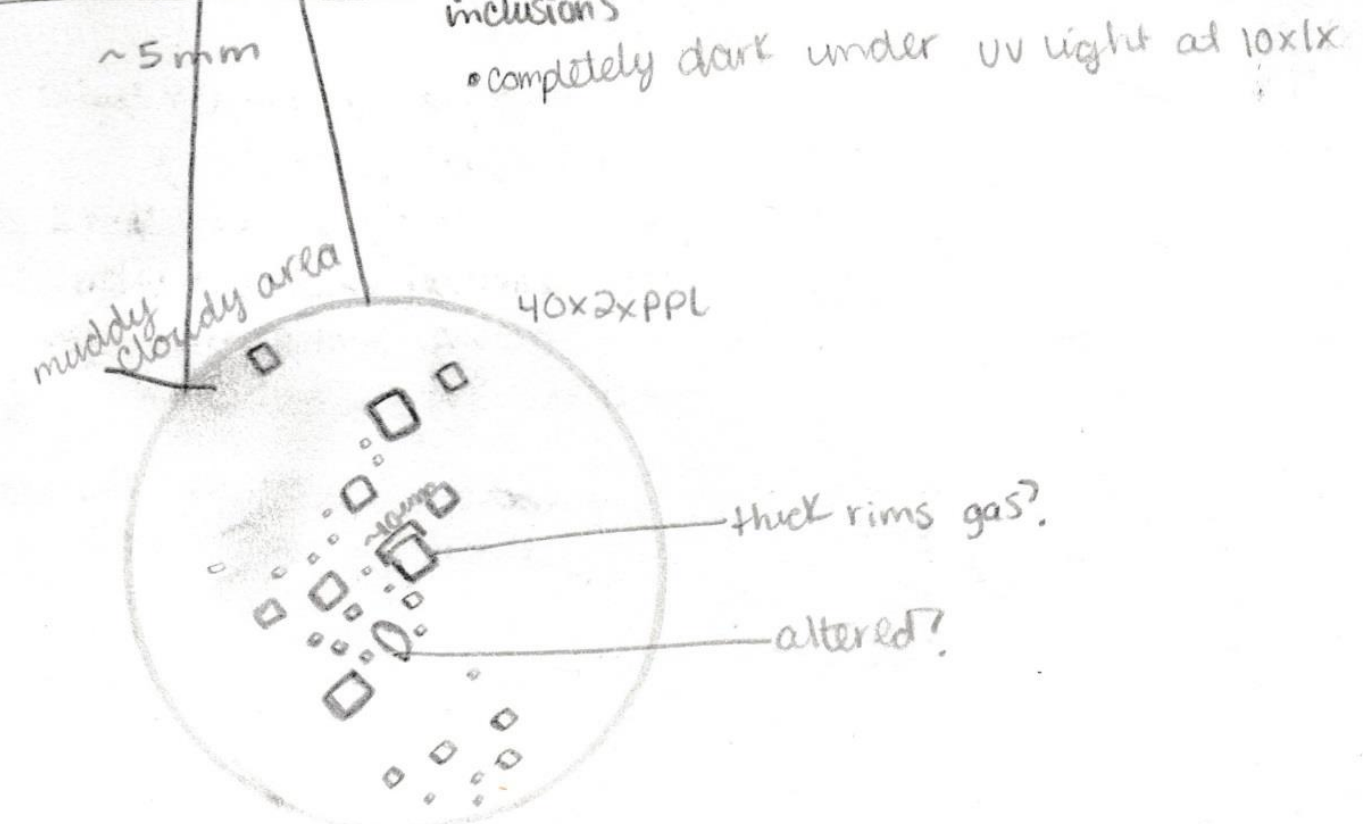

- completely black under UV Ught

- all liquid distinct + plentiful in clear areas of

\$ laser Raman Sarryple 
Eichenlaub, L.A., 2016

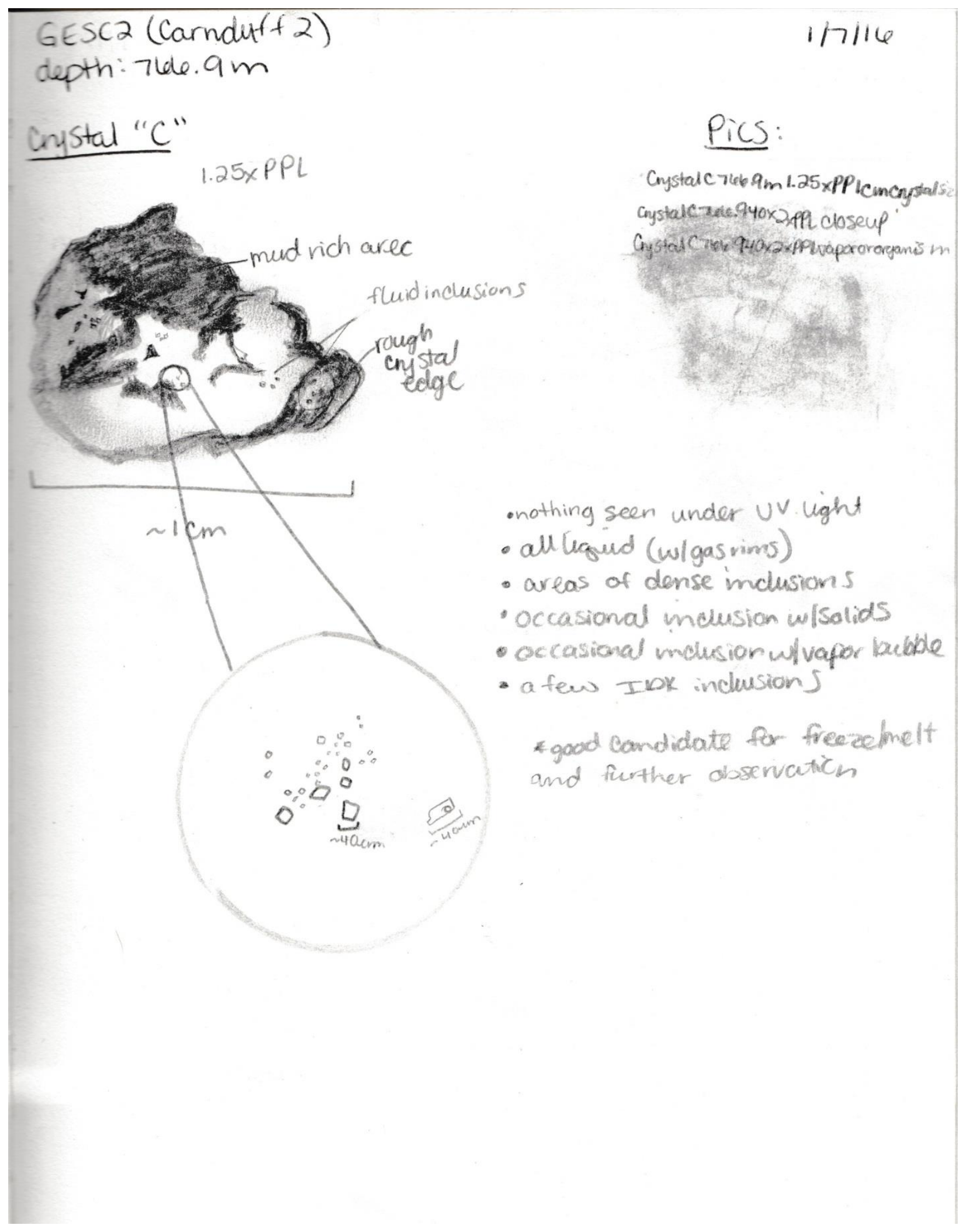


Eichenlaub, L.A., 2016

Core: GESCa (Cainduitt a)

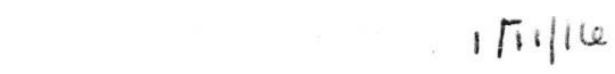
depth: $804.8 \mathrm{~m}$

Crystal "A"

$4 \times 1 \times P P L$
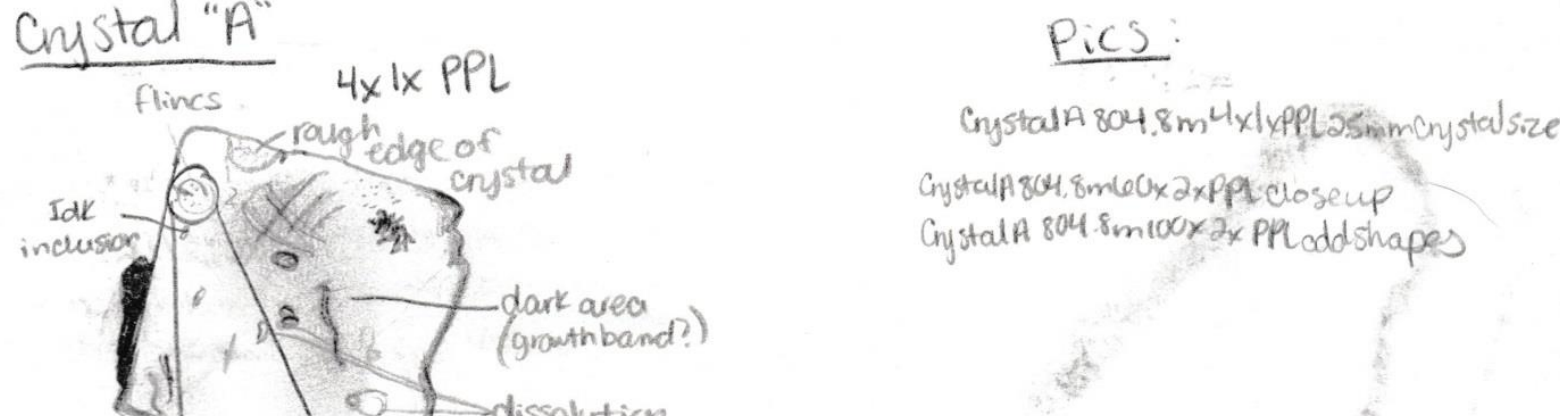

(grouthband?)

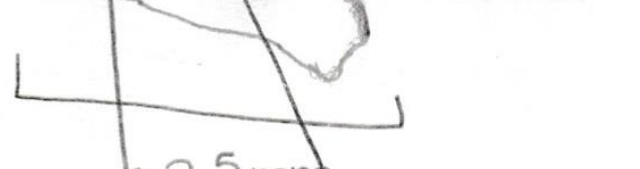

thick rims of gas?

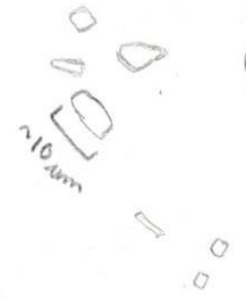

- all liquid (except rims)

- no solids

- random idk inclusion Seen

in uncle coystal

- Completely black in UV ught 
Eichenlaub, L.A., 2016

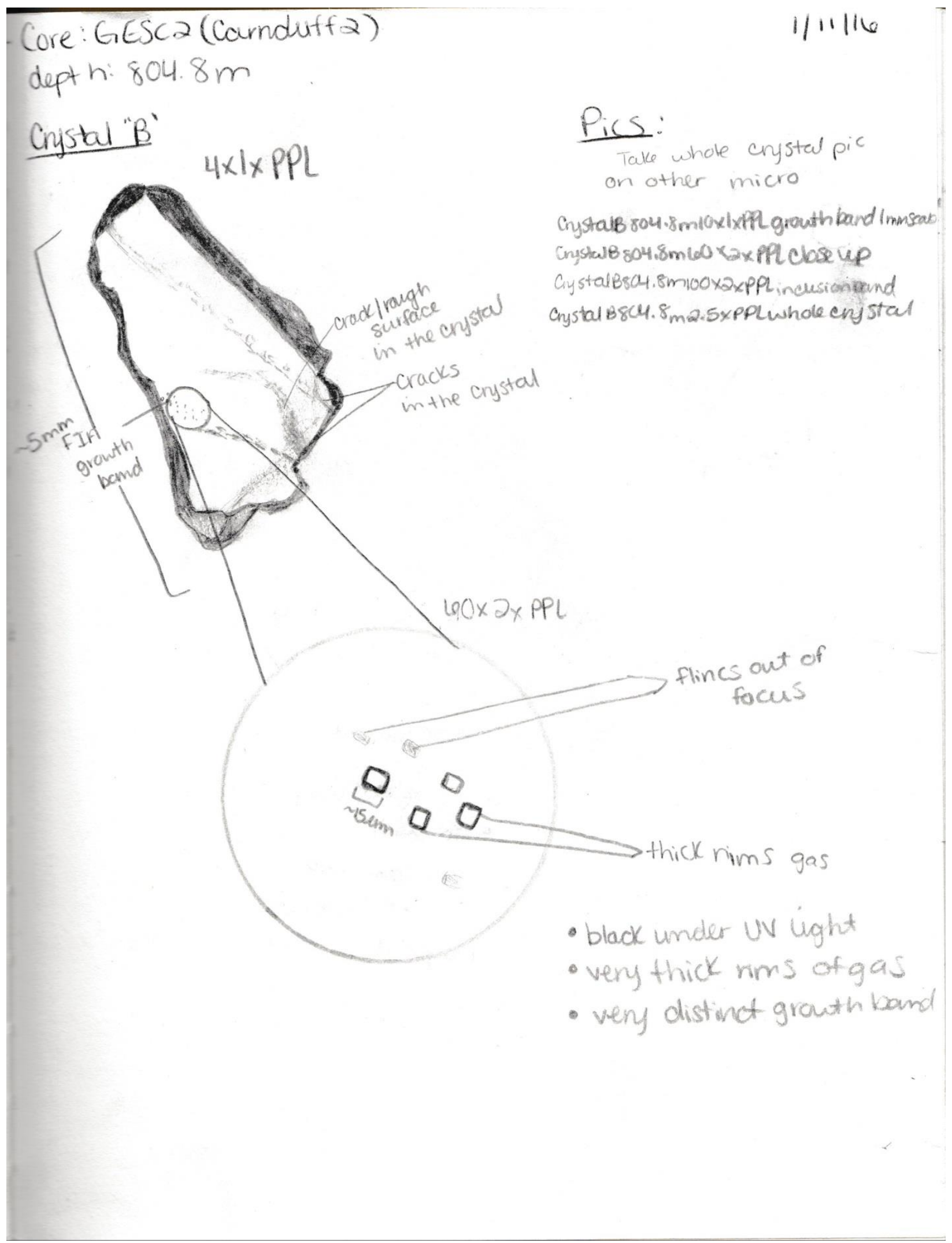


Eichenlaub, L.A., 2016

Core: GESCa (Carnoluff 2)

depth: $804.8 \mathrm{~m}$

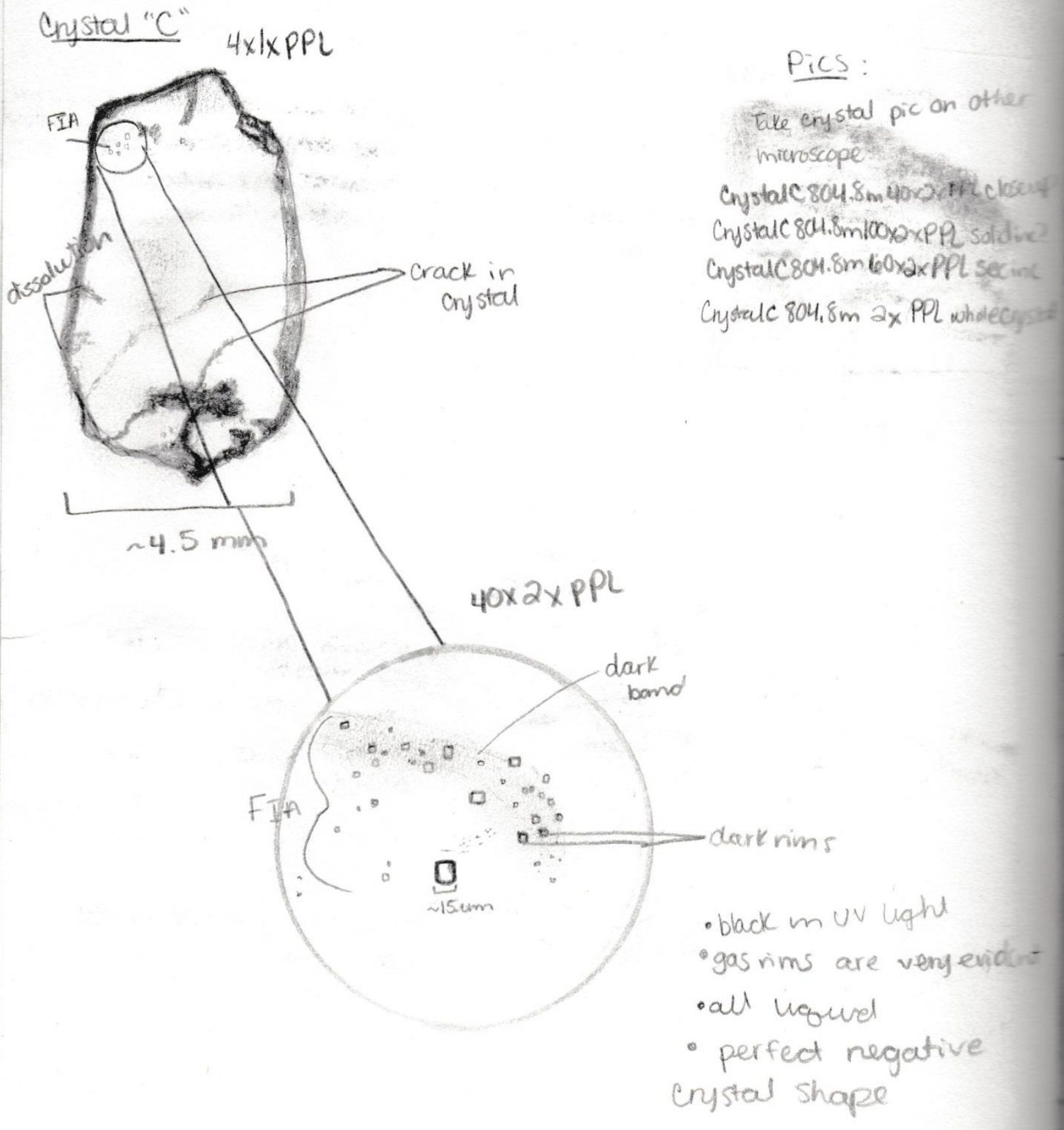


Eichenlaub, L.A., 2016

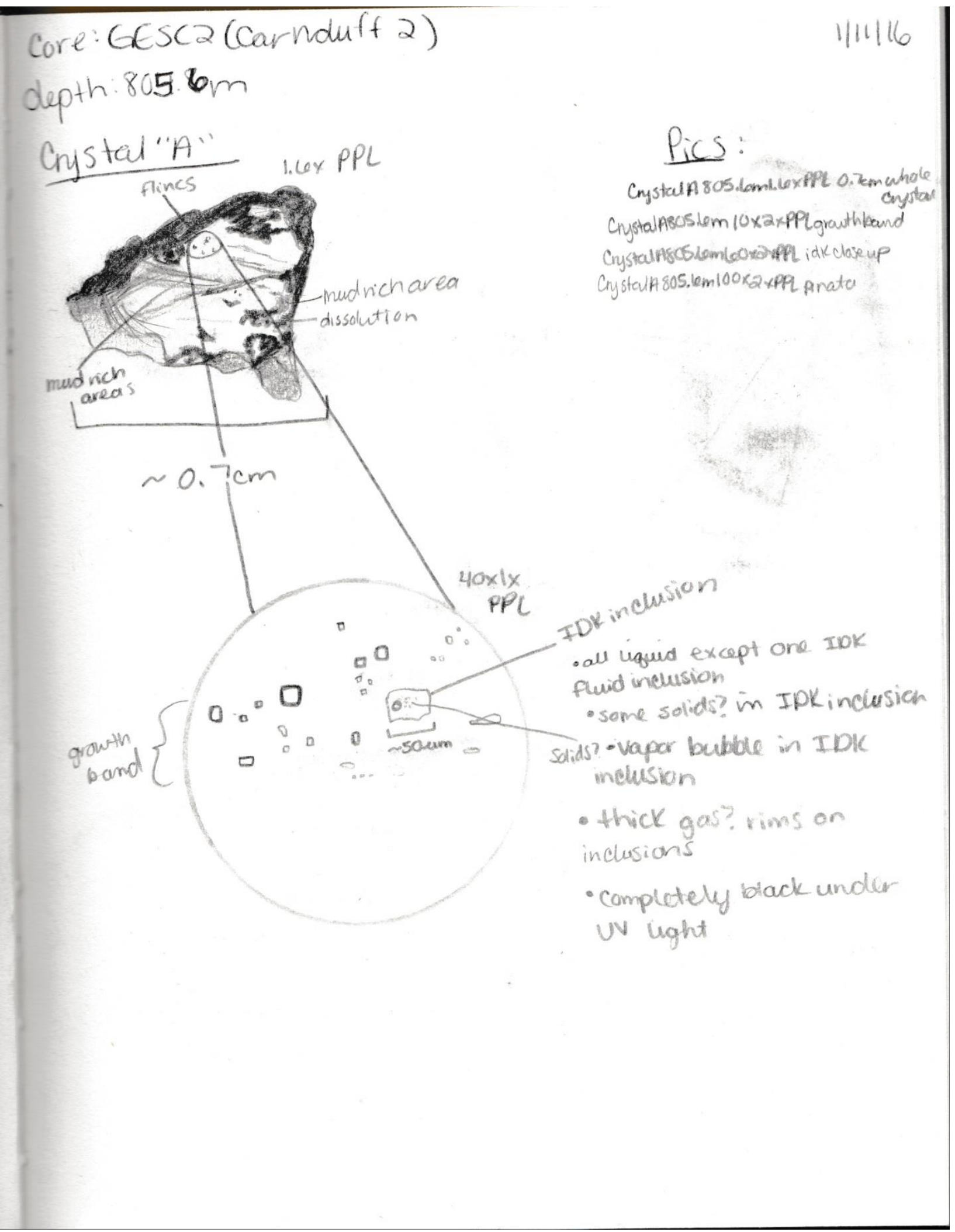


Eichenlaub, L.A., 2016

Core: GESCD (Carnduff 2 )

$1 / 11 / 16$ depth: $805.6 \mathrm{~m}$

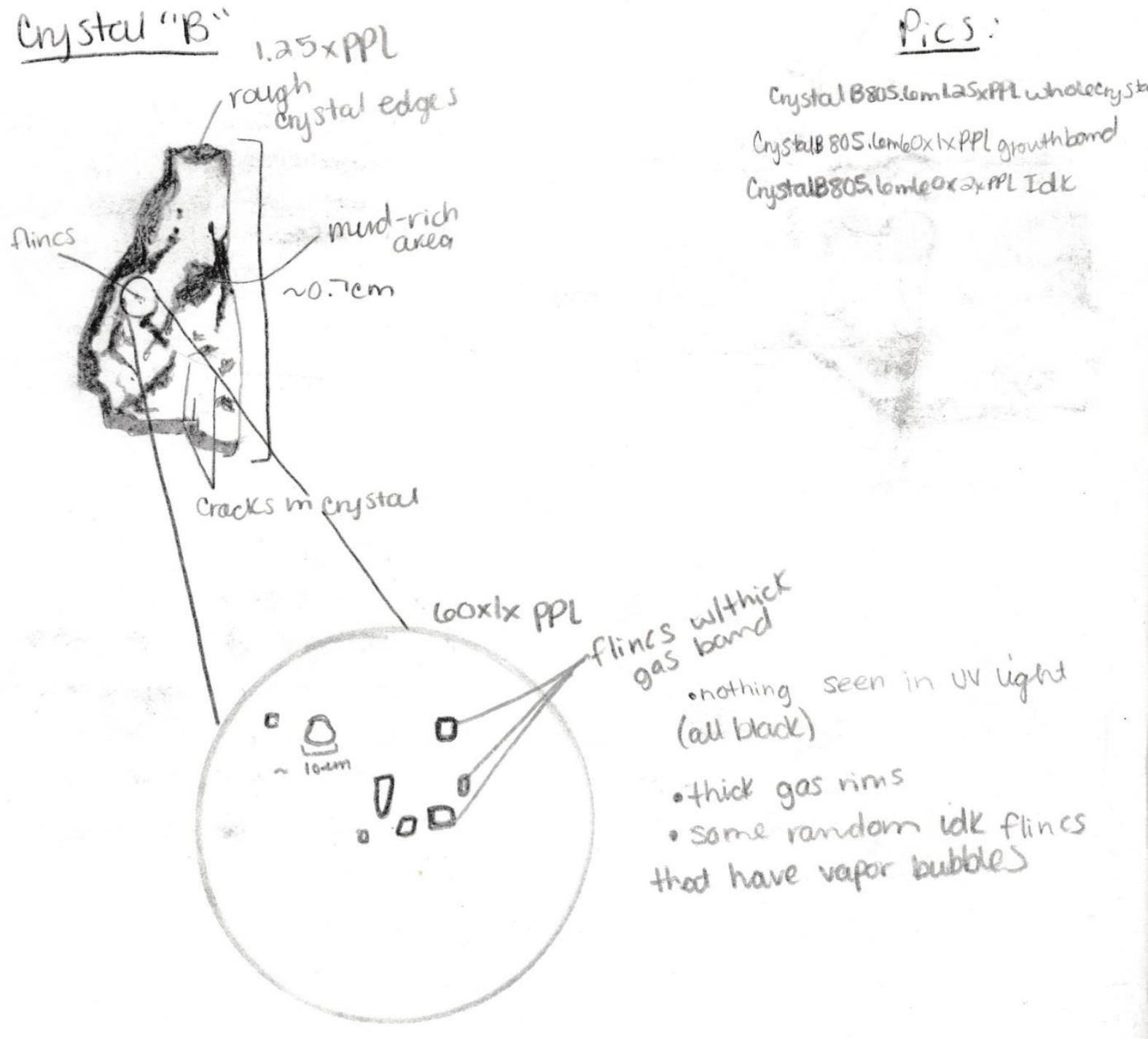


Eichenlaub, L.A., 2016

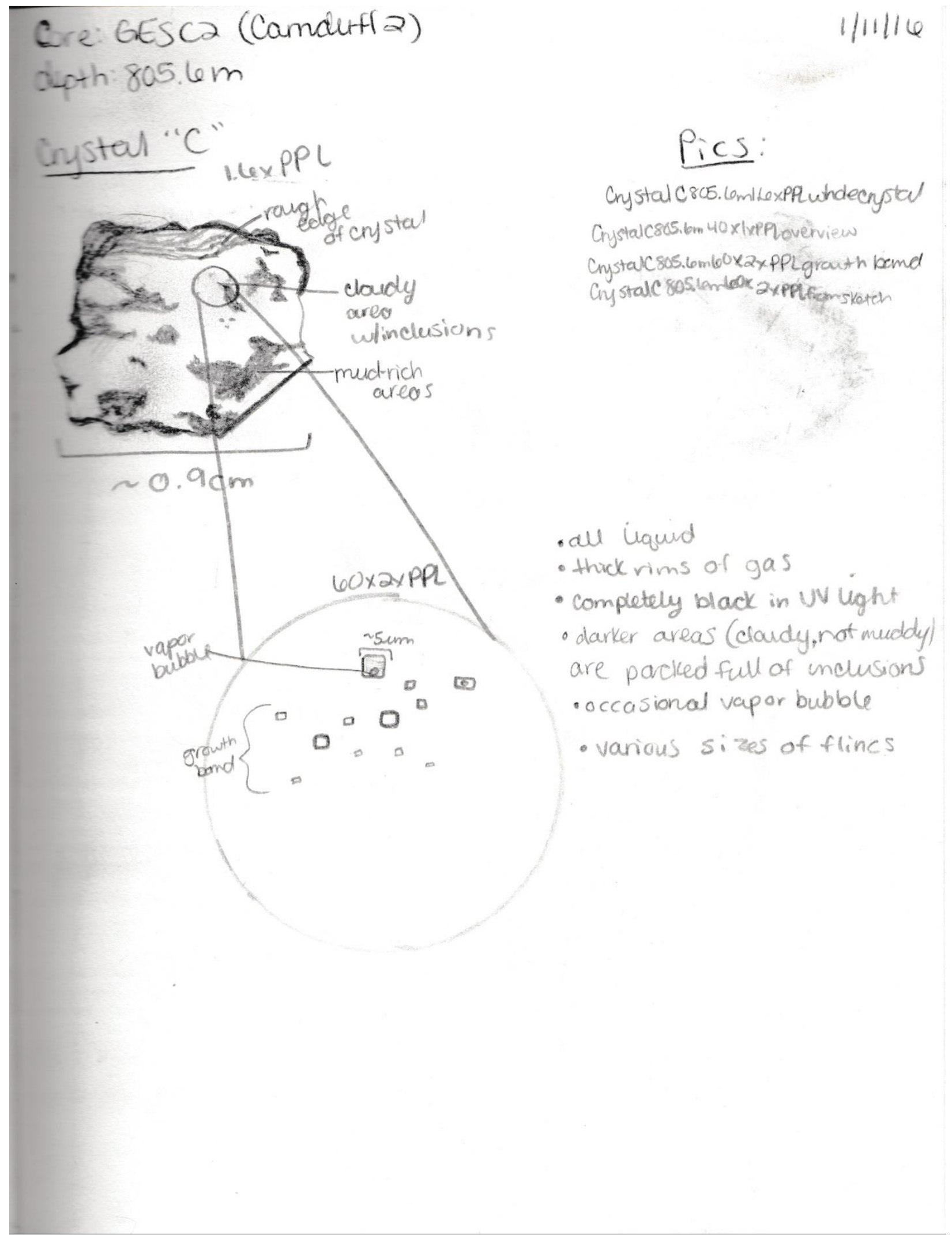


Eichenlaub, L.A., 2016

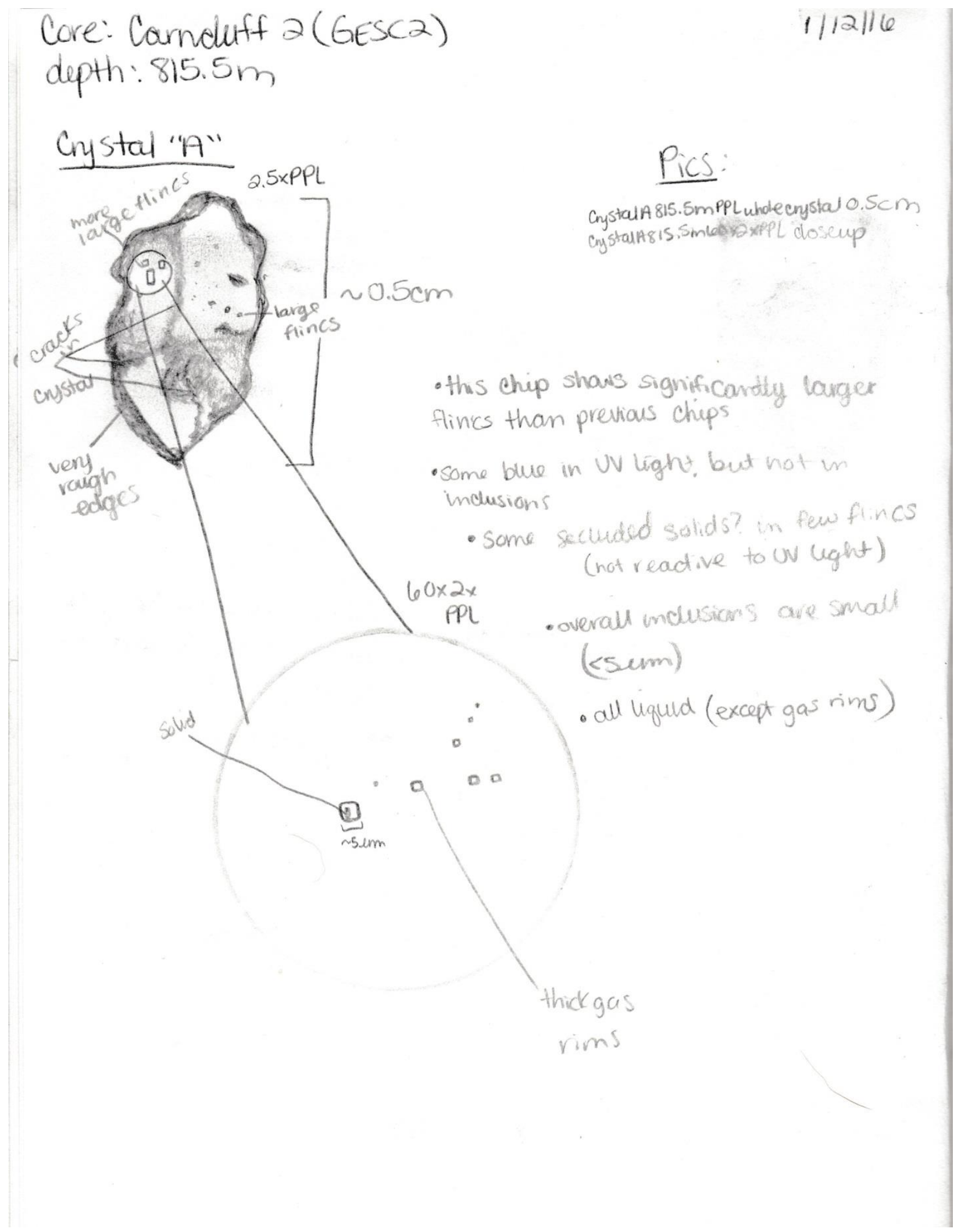


Eichenlaub, L.A., 2016

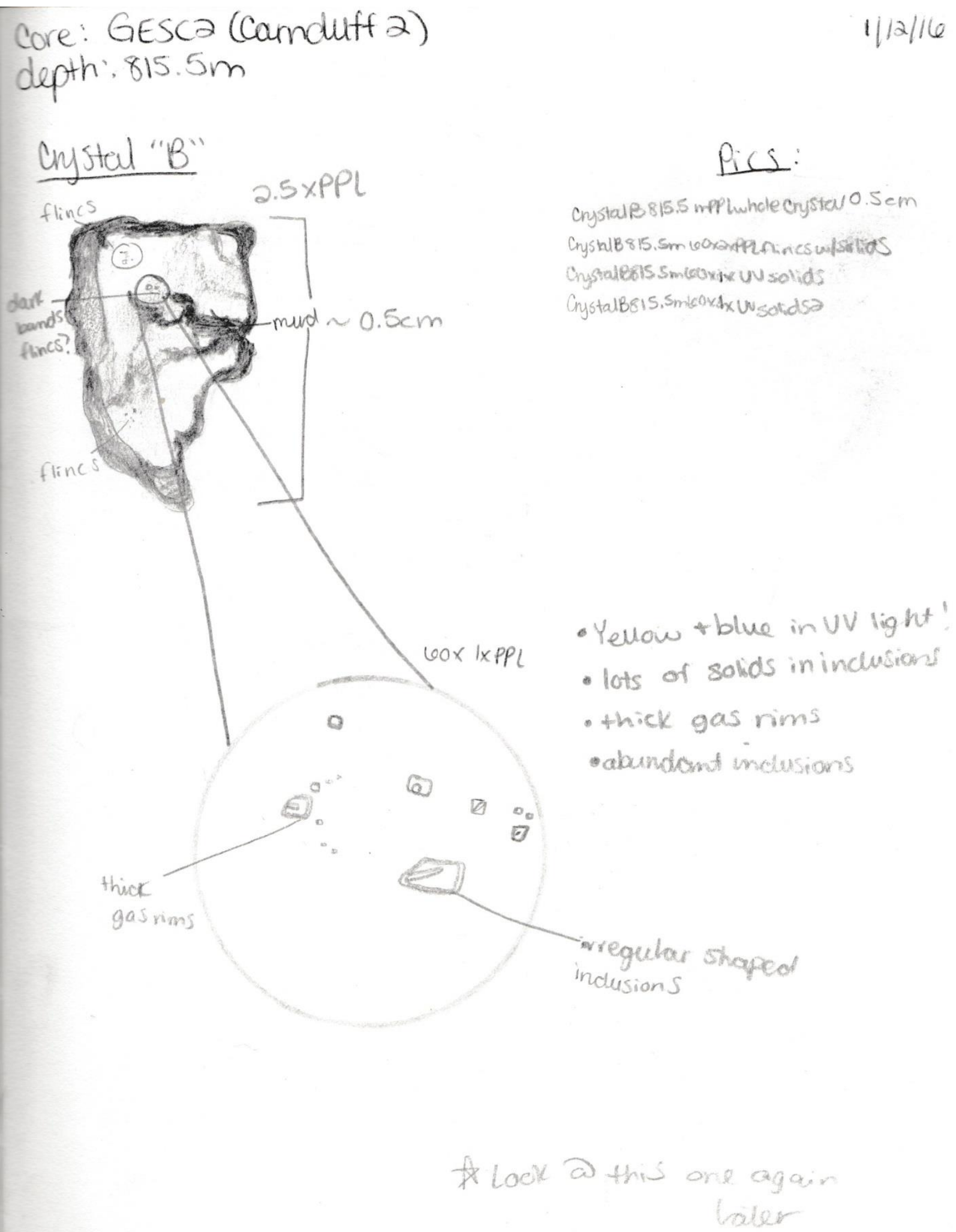


Eichenlaub, L.A., 2016

Core: GESCA (Carnduffa)

depth: $815.5 \mathrm{~m}$

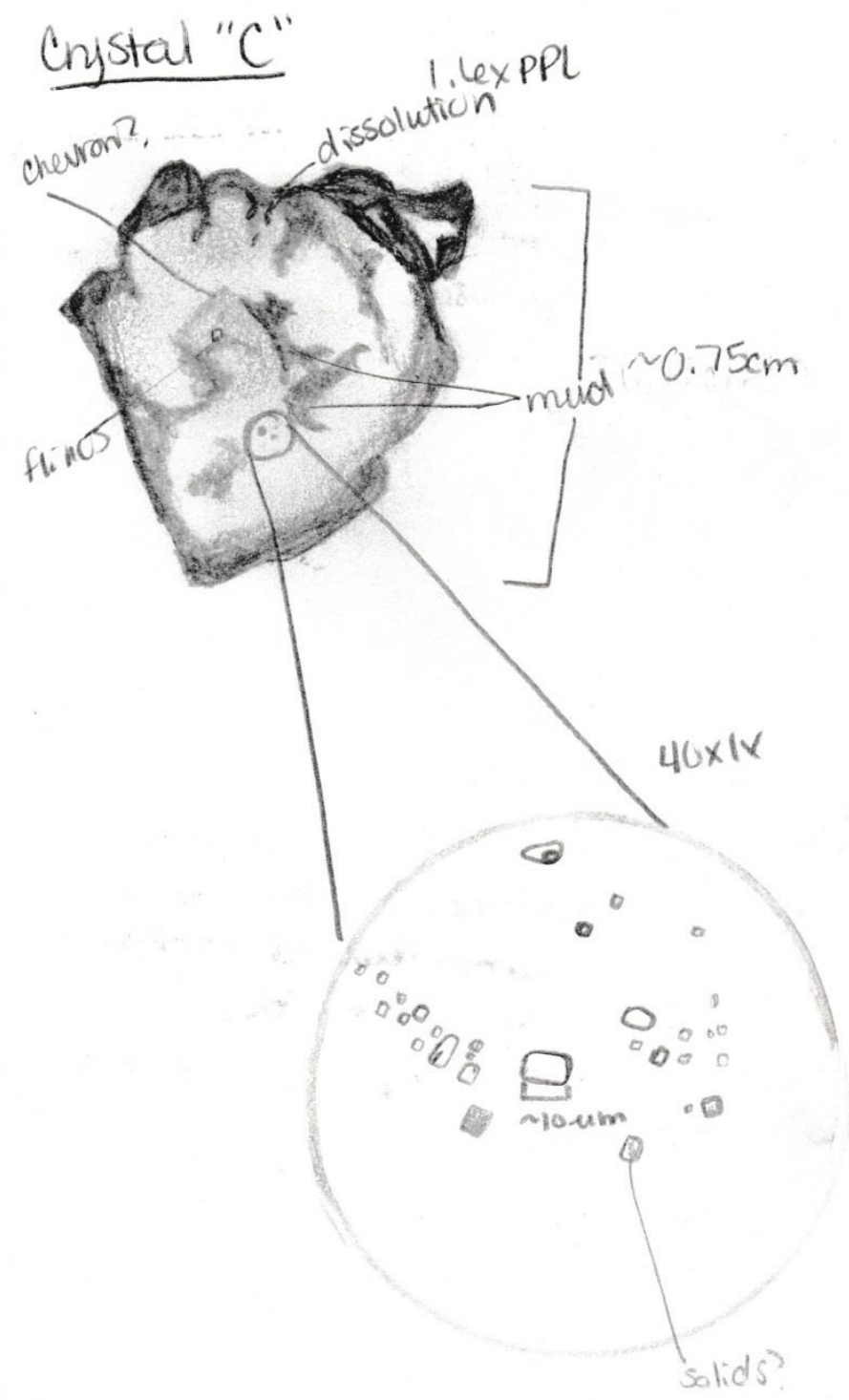

- all black under UV Ught

- some occasional IDK inclusiors wi vapar bubbles

- thick rims gas?)

- some inclusions Contain

Solids (not reactive to UU Uight) 
Eichenlaub, L.A., 2016

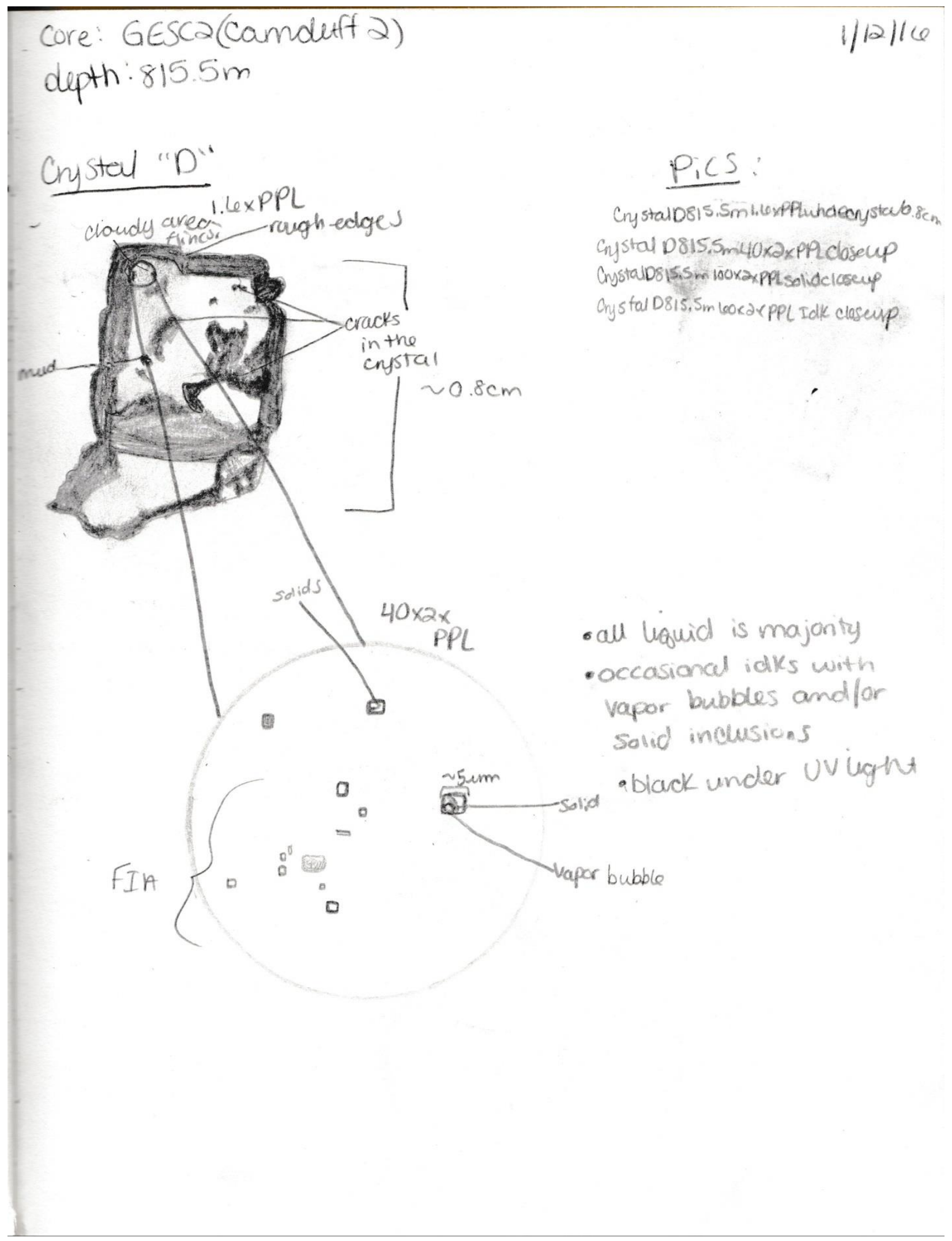


Core: GESCZ (Carnduff 2) depth: $819 . \mathrm{lem}$

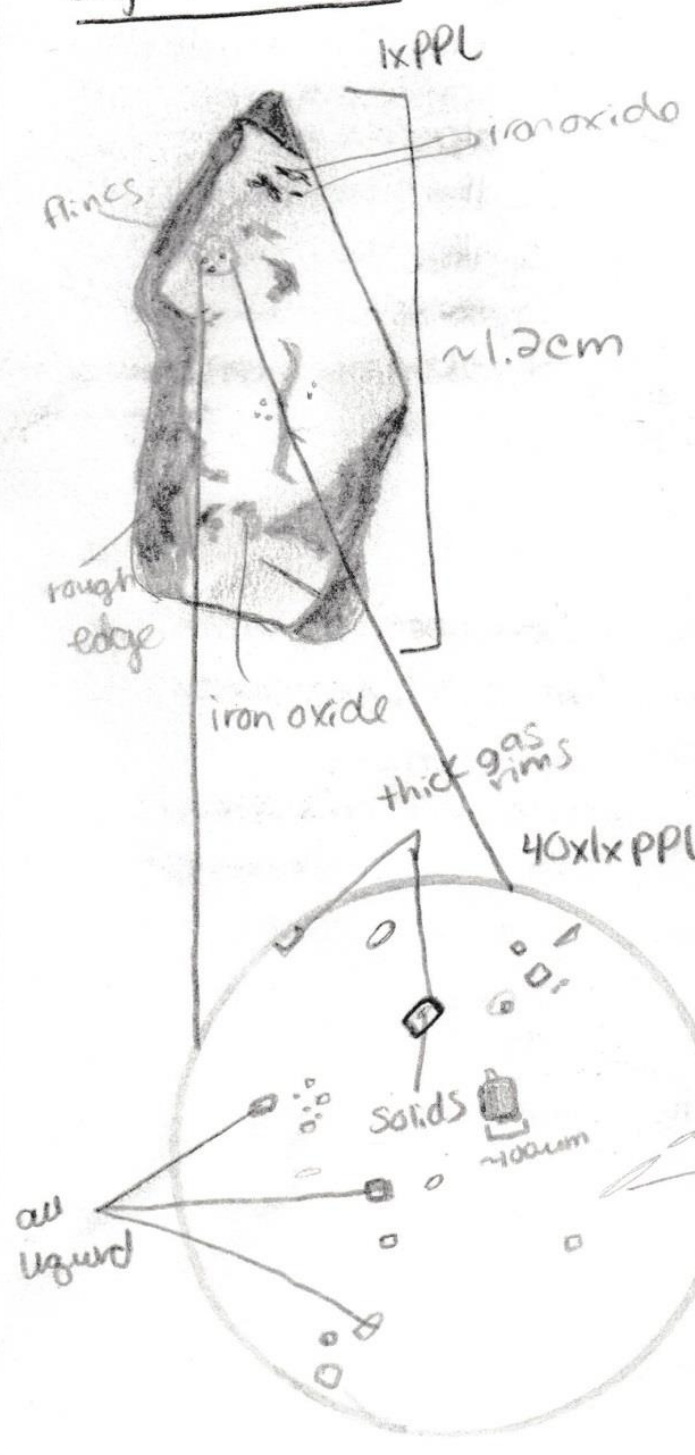

Pics.

CrystalA819.6m 1xppl wholecrystal1.2cm CrystalA 819.im $4 \times 2 \times P$ Pl seeandaryincs. CystalA 819.6m40xlyppl Id kusatids: Cnystala819.6m40xlxPPLion mind ChystalA $819.6 \mathrm{~m} 40 \times 1 \times \cup \cup$ mid ChjstalA819.6mU $\times 2 \times P A$ grow theands Coystalit 819,4mboxlvPPLUVflincs. CnystalA 819.6 an $60 \times 1 \times$ UVflings

- hud is reactive to UV ught

- some IDK crystals wlvapor bubbles + solids, but ne reaction to UV lught

- all liguid indusions

- gas rims

- distinct growth bands

- solids in some melusions (ne to UV attered inclusions? - some fincs react to W(blue,yellow)

Agood candidate for Loser Raman 
Eichenlaub, L.A., 2016

\section{Core: GESC2 (Carnduff 2) depth: $819.6 \mathrm{~m}$}


Pics:

- take pic on other scope constale8 19.6m 40x2xPPLClose up Crystal 8819.10 m100 x2xPPL pinata Cnystalb819.6mile $\times 1 \times$ PP flines CnstalB819.6m60 $61 \times$ Uuffincs CnstalB819.6m60X2XPPlidkflinc CrystalB819.6m60ra2x UVidKflin CrystalB819,10m2.5 xpplwhelecnystou senmerysteds.



(dissolution)

- thick gas rims

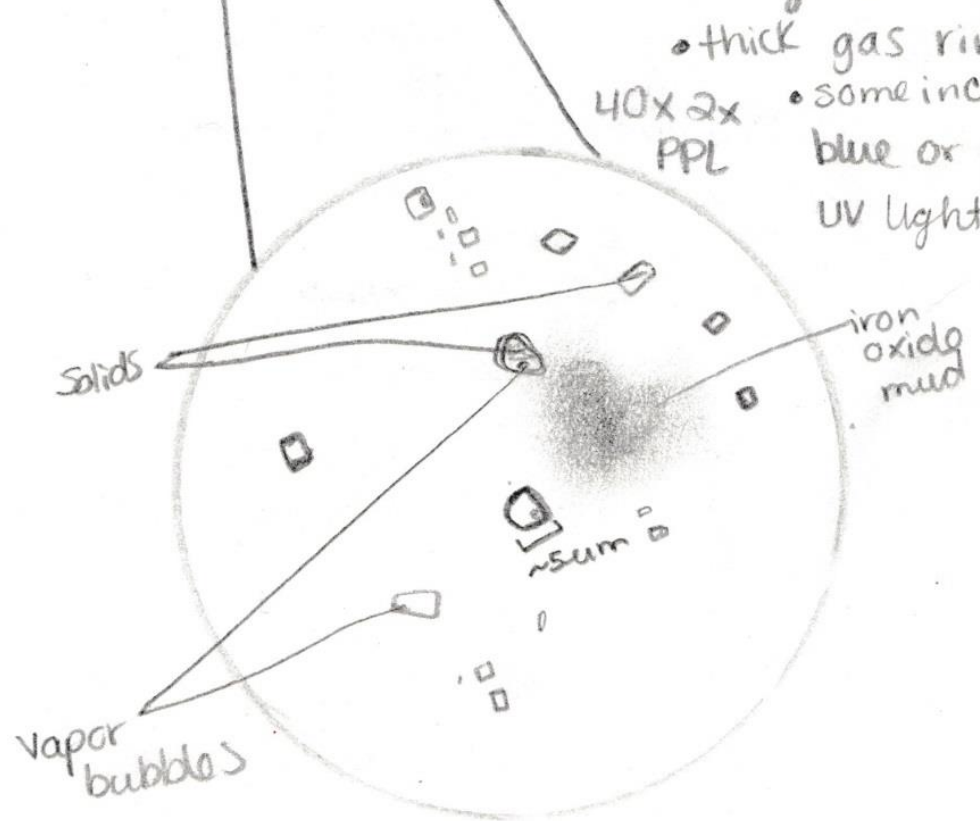


Eichenlaub, L.A., 2016

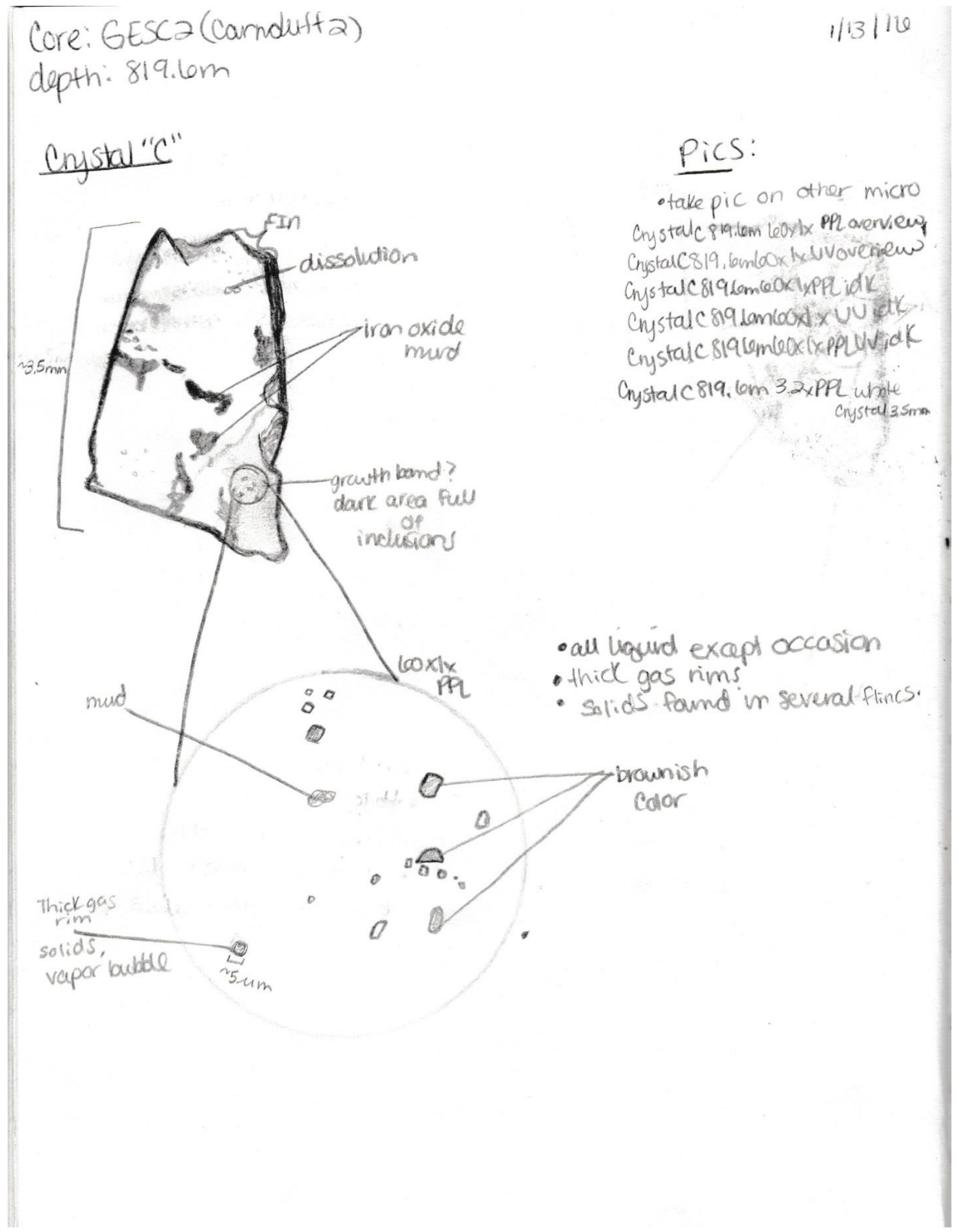


Eichenlaub, L.A., 2016




Eichenlaub, L.A., 2016

Core: GESC2 (Carnduft2)

$1 / 13 / 16$ depth: $841.55 \mathrm{~mm}$

Chystal 'B" in whirlpack

$$
0.63 \times P P L
$$

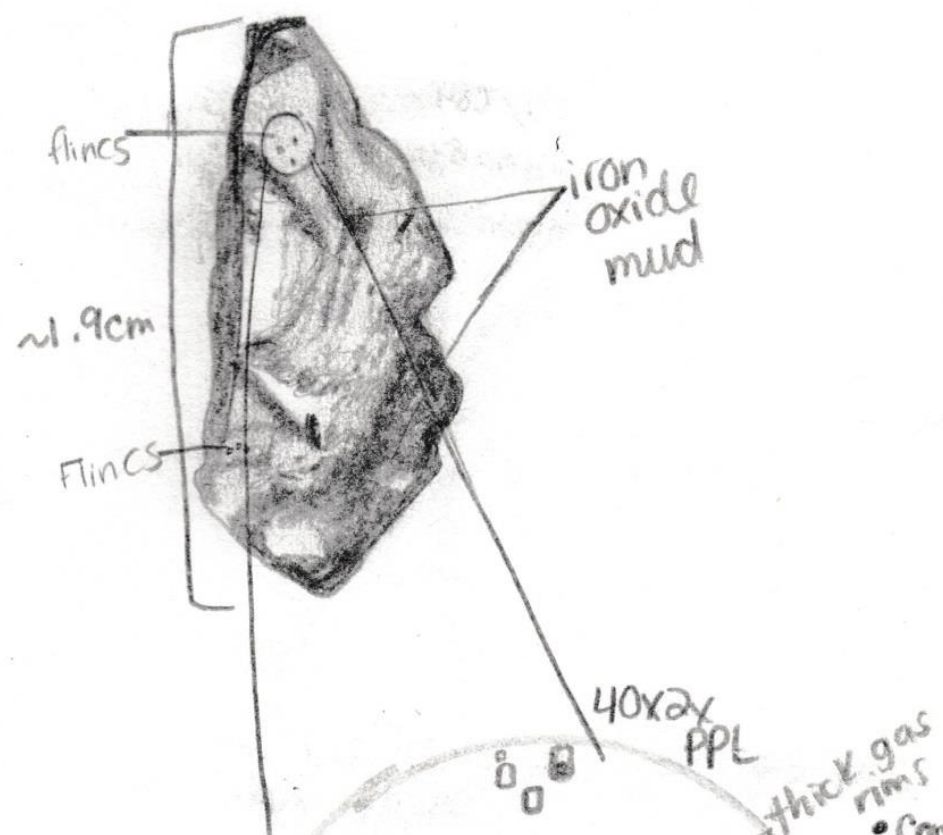

$$
\begin{aligned}
& \text { - PiCS; } \\
& \text { CnystalB 84155 m0.63 xPPL wholecenstal } \\
& \text { i } 19 \text { cma } \\
& \text { CrystalB 841.5sm49020 PPL Closeup } \\
& \text { CystalBsulss. } 40 \text { xix PPl breached }
\end{aligned}
$$

- Completely black under UV ugnI - thick gas rims

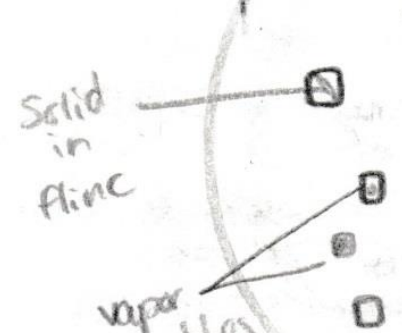

- mostly all liquurd-a-fees seduded flincs wil vapor bubble

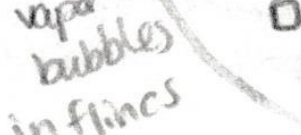


Eichenlaub, L.A., 2016






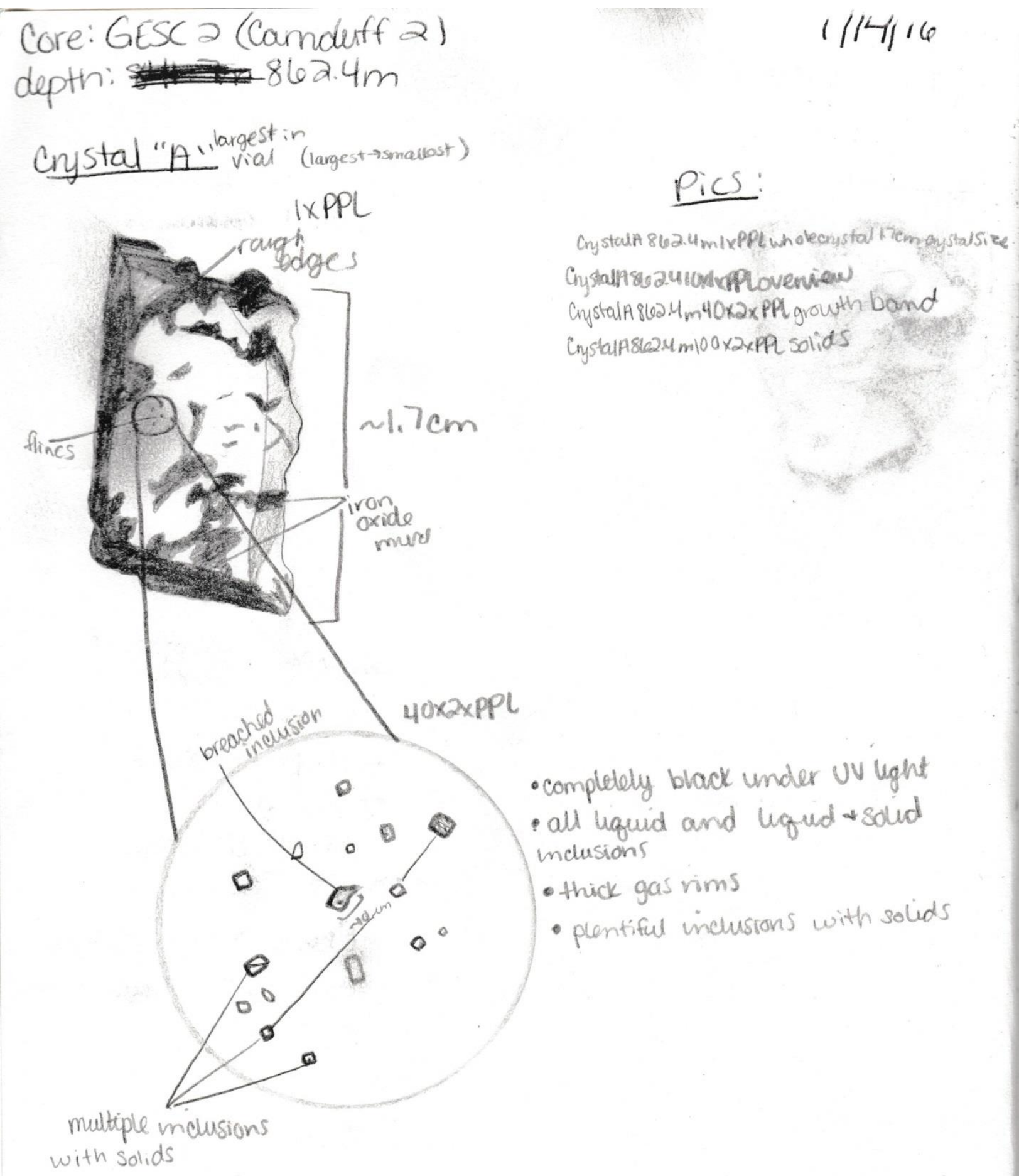


Eichenlaub, L.A., 2016

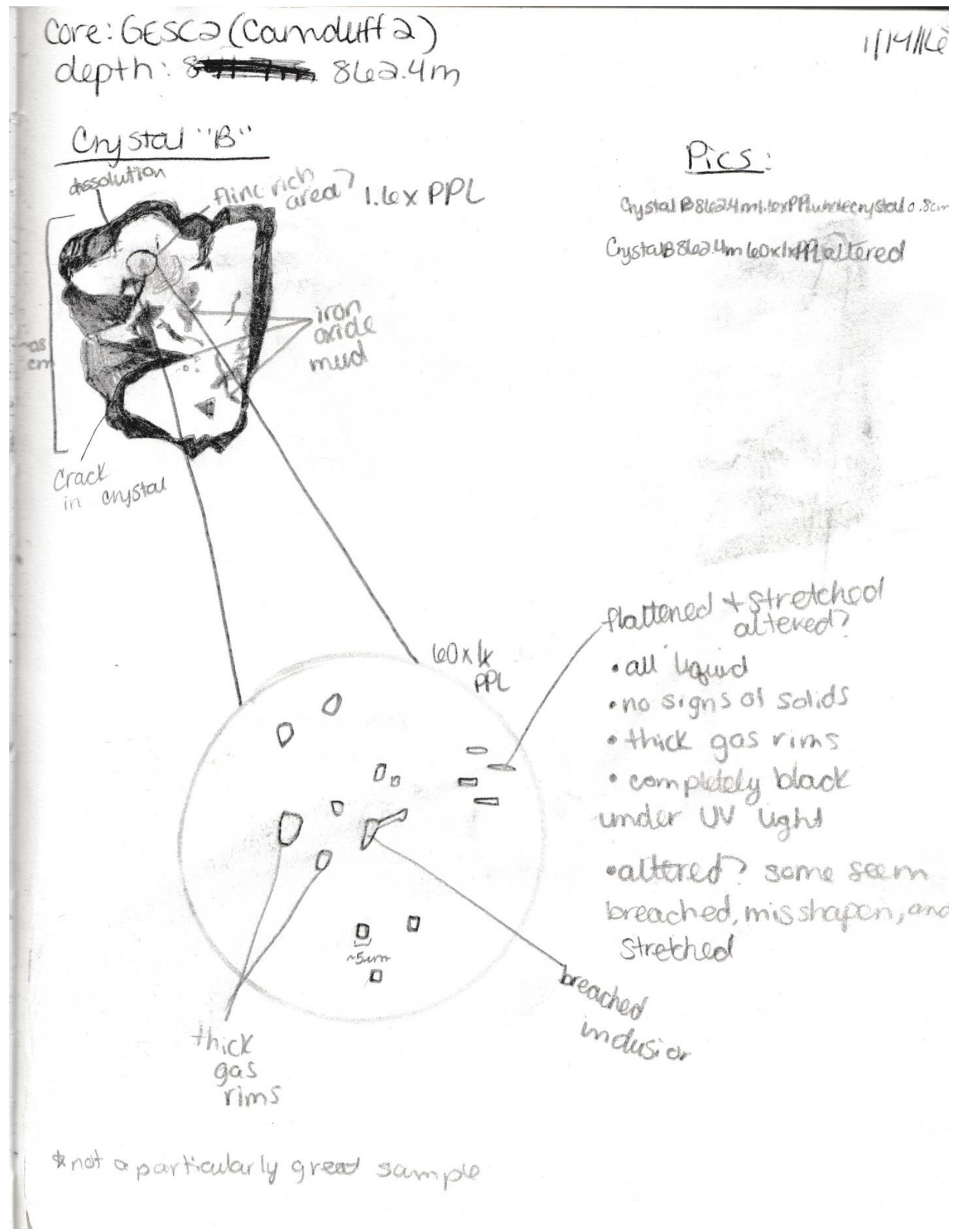


Eichenlaub, L.A., 2016

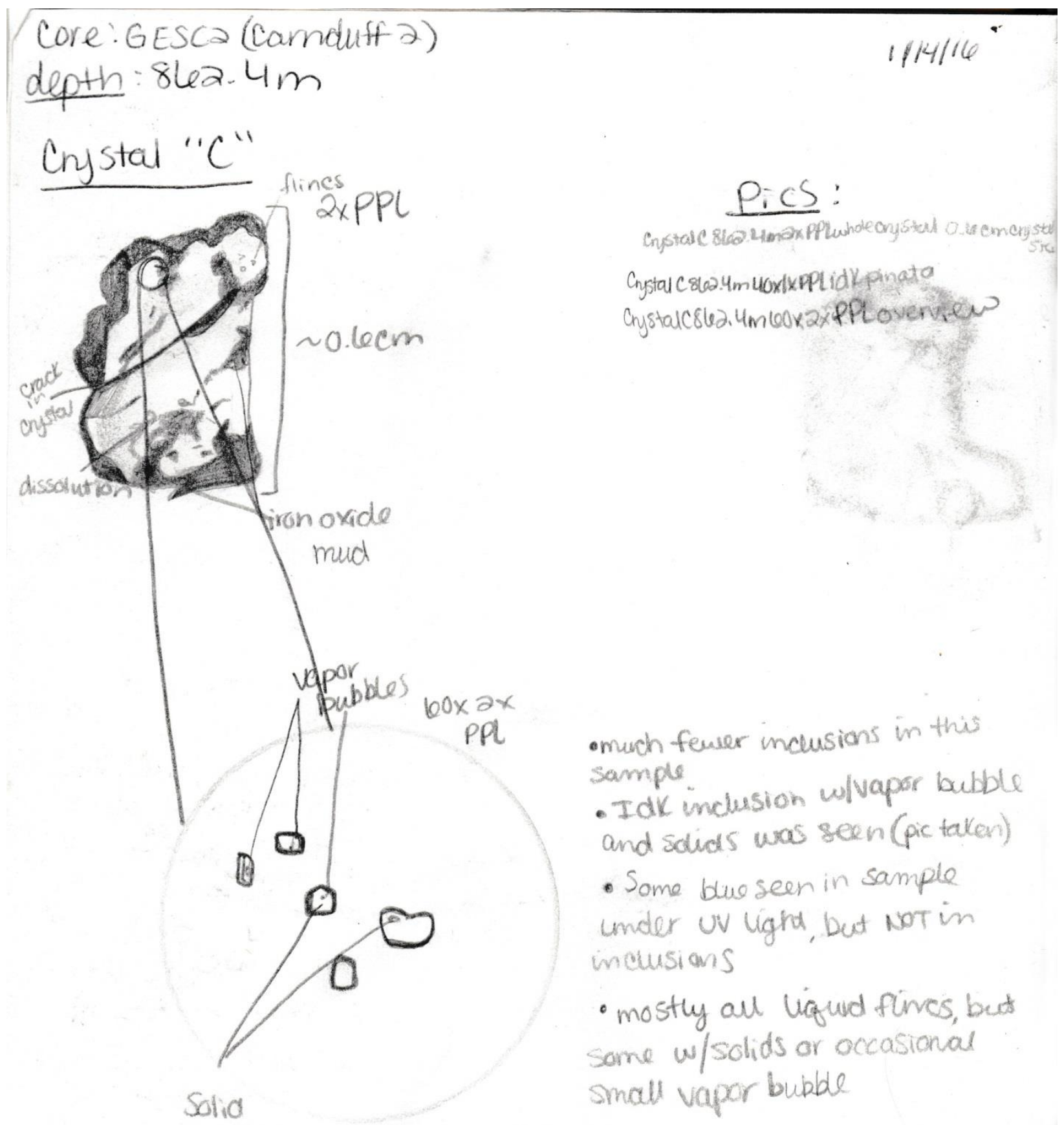


Eichenlaub, L.A., 2016

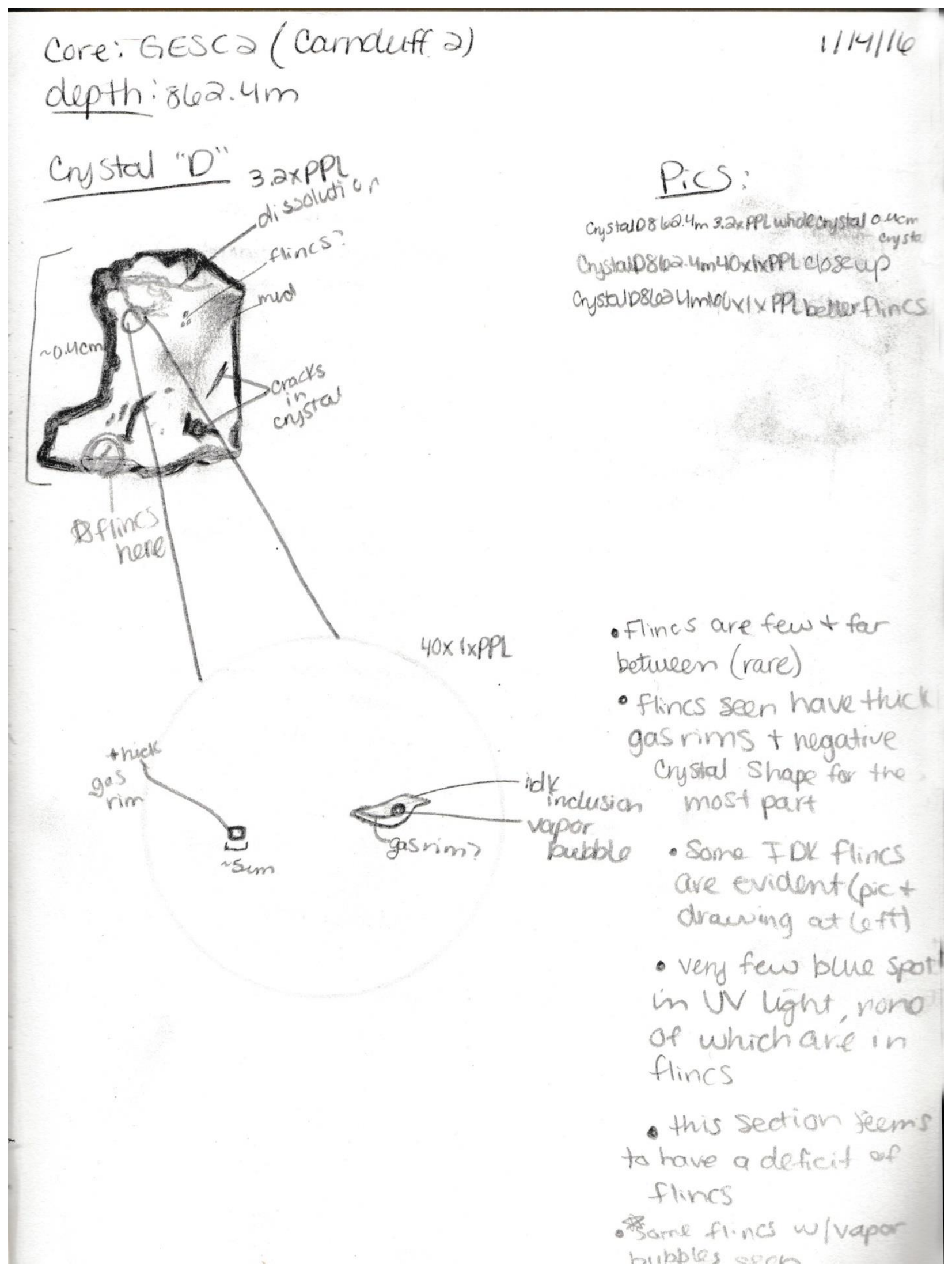


Eichenlaub, L.A., 2016

Core. GESCQ (Carndurf 2)

$11 / 24 / 15$

depth: $887 \mathrm{~m}$

Crystal "A" $4 \times 1 \times$ PPL PiCs:

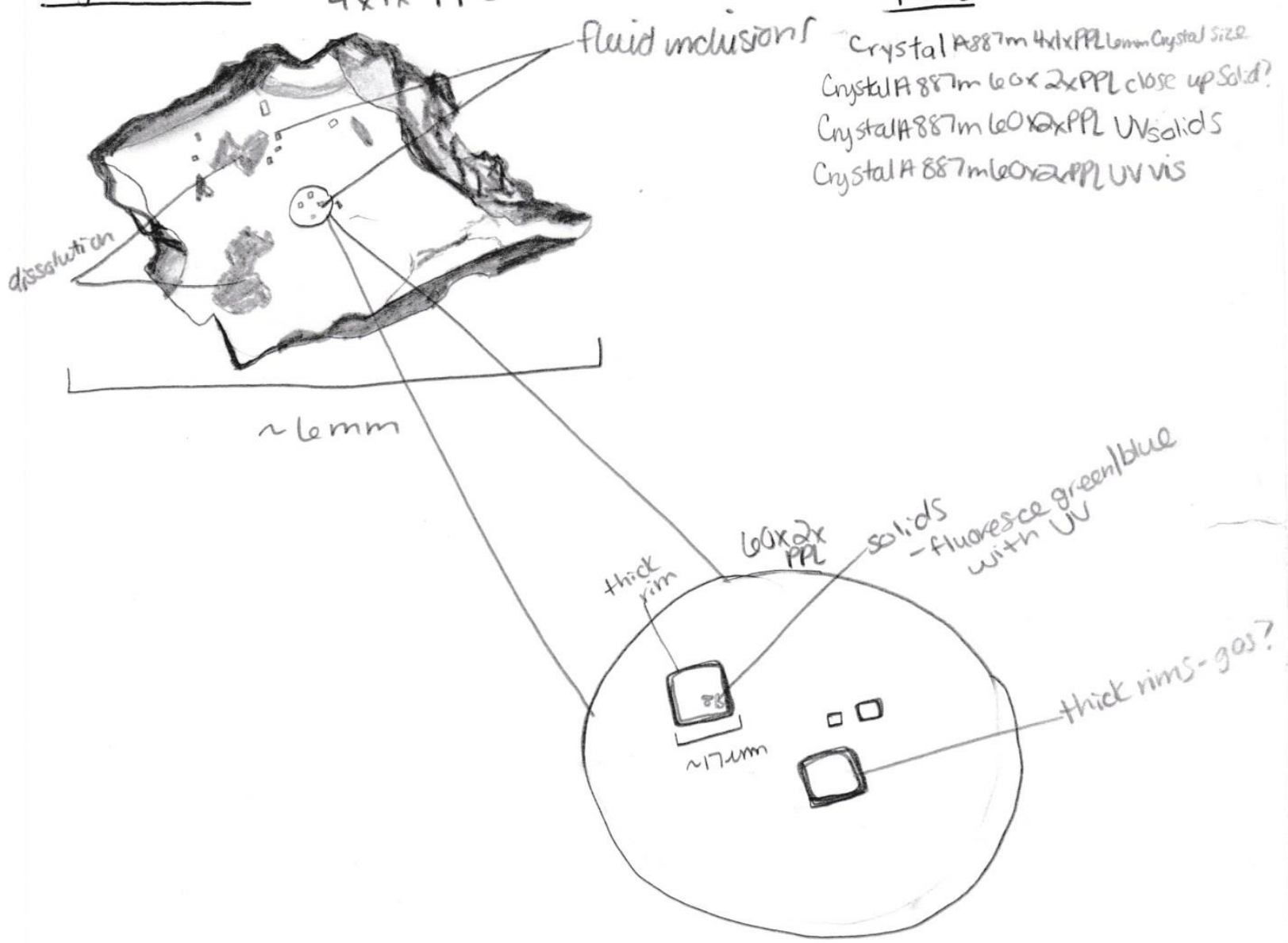


Eichenlaub, L.A., 2016

Core: GESC2 (Carnduff 2)

11124113

depth:88n m

Crystal "B"
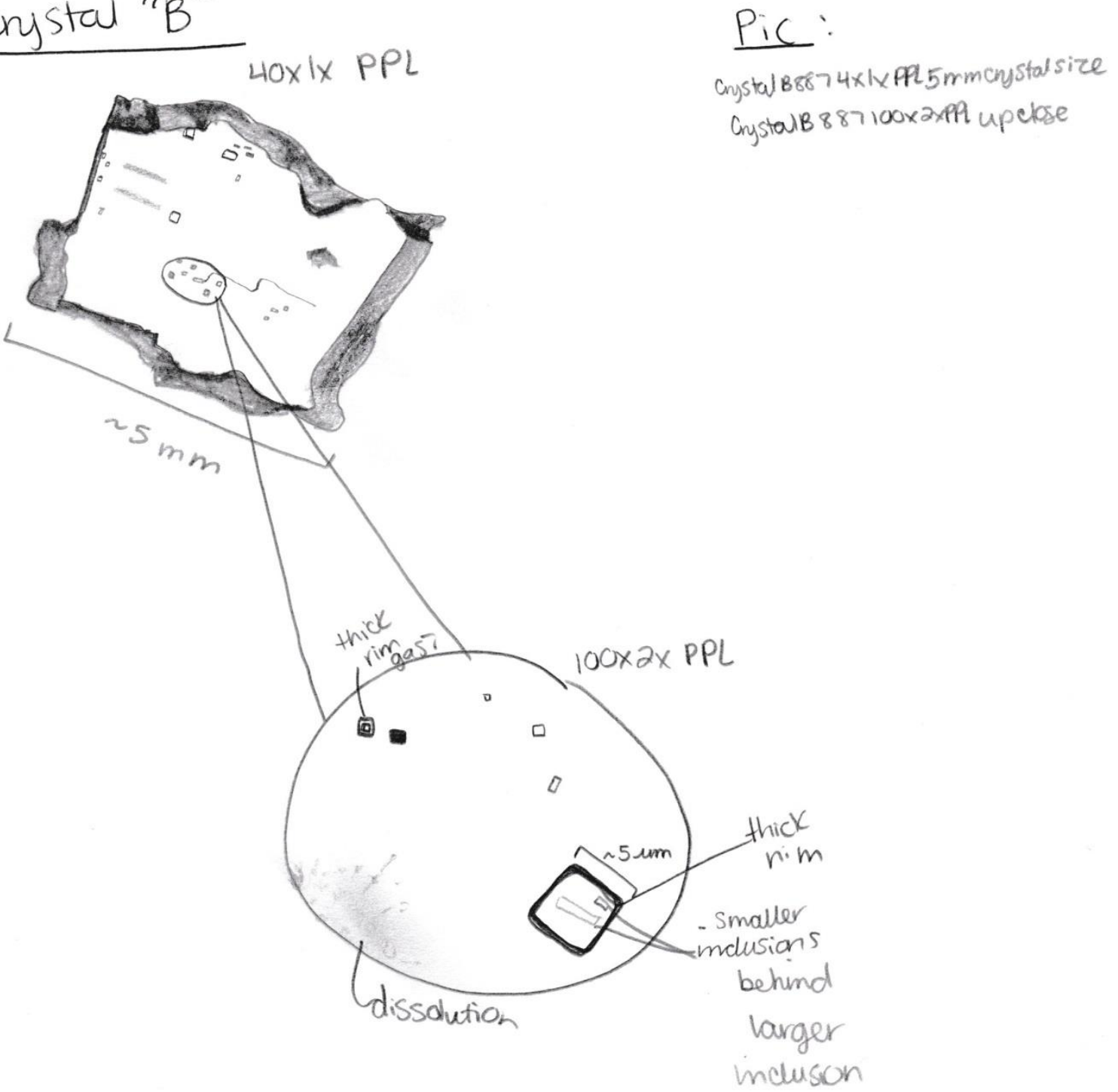
Eichenlaub, L.A., 2016

GESC2 (Canduft 2)

depth: $887 \mathrm{~m}$

crystal "C"

$40 \times 1 \times \mathrm{PPL}$

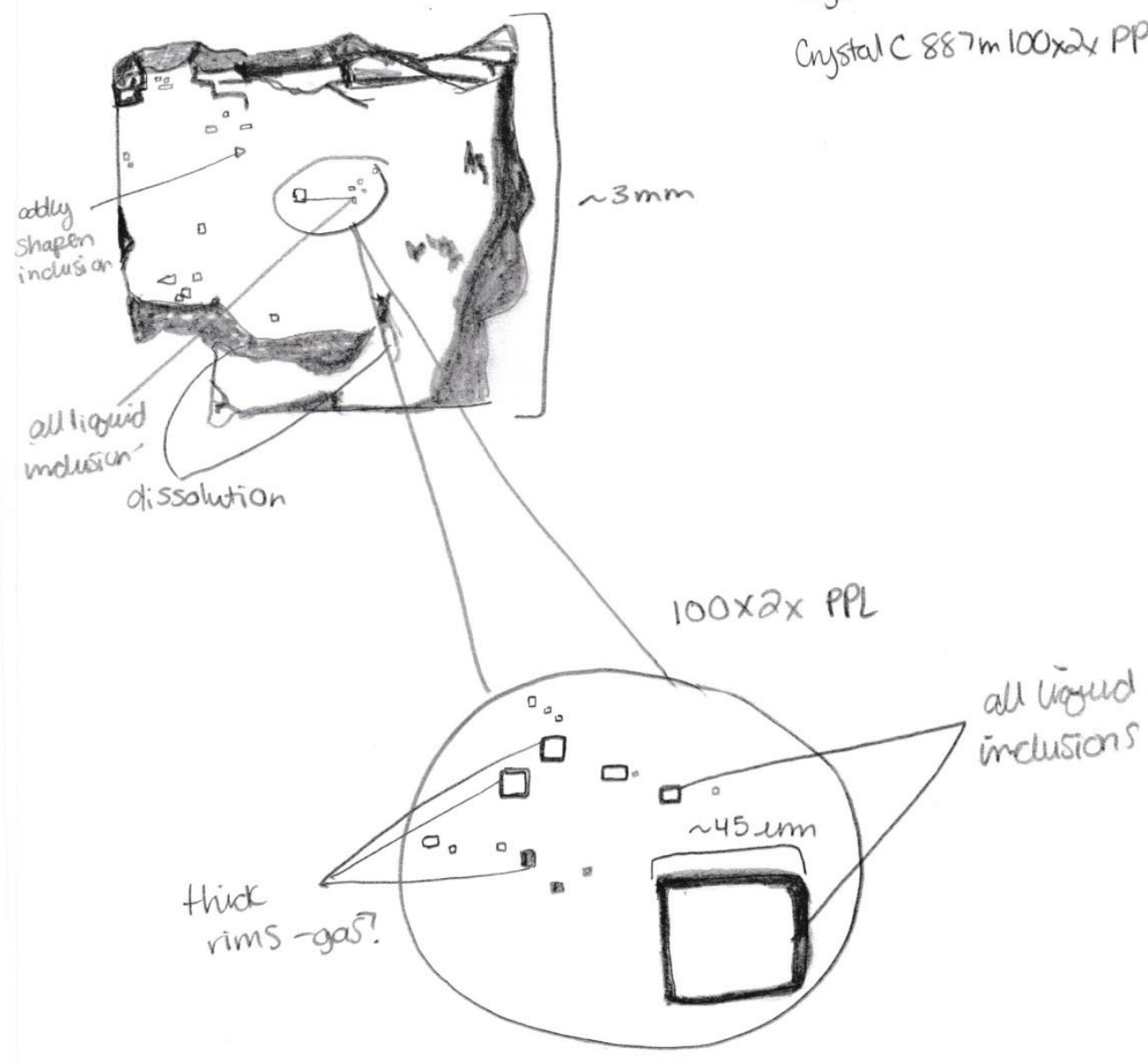

Pics:

Cnystal C $887 \mathrm{~m} 40 \times 1 \times$ PPL 5 mmcrystal size Cnystal C $887 \mathrm{~m} 100 \times 2 \times$ PPL close uP

plaser Raman Sample 
Eichenlaub, L.A., 2016

Core: GESCa (Carnduff 2)

$11 / 20 / 15$ depth: goled $m$

$\frac{\text { Crystal "A" }}{4 \times 1 \times \text { PPL }}$

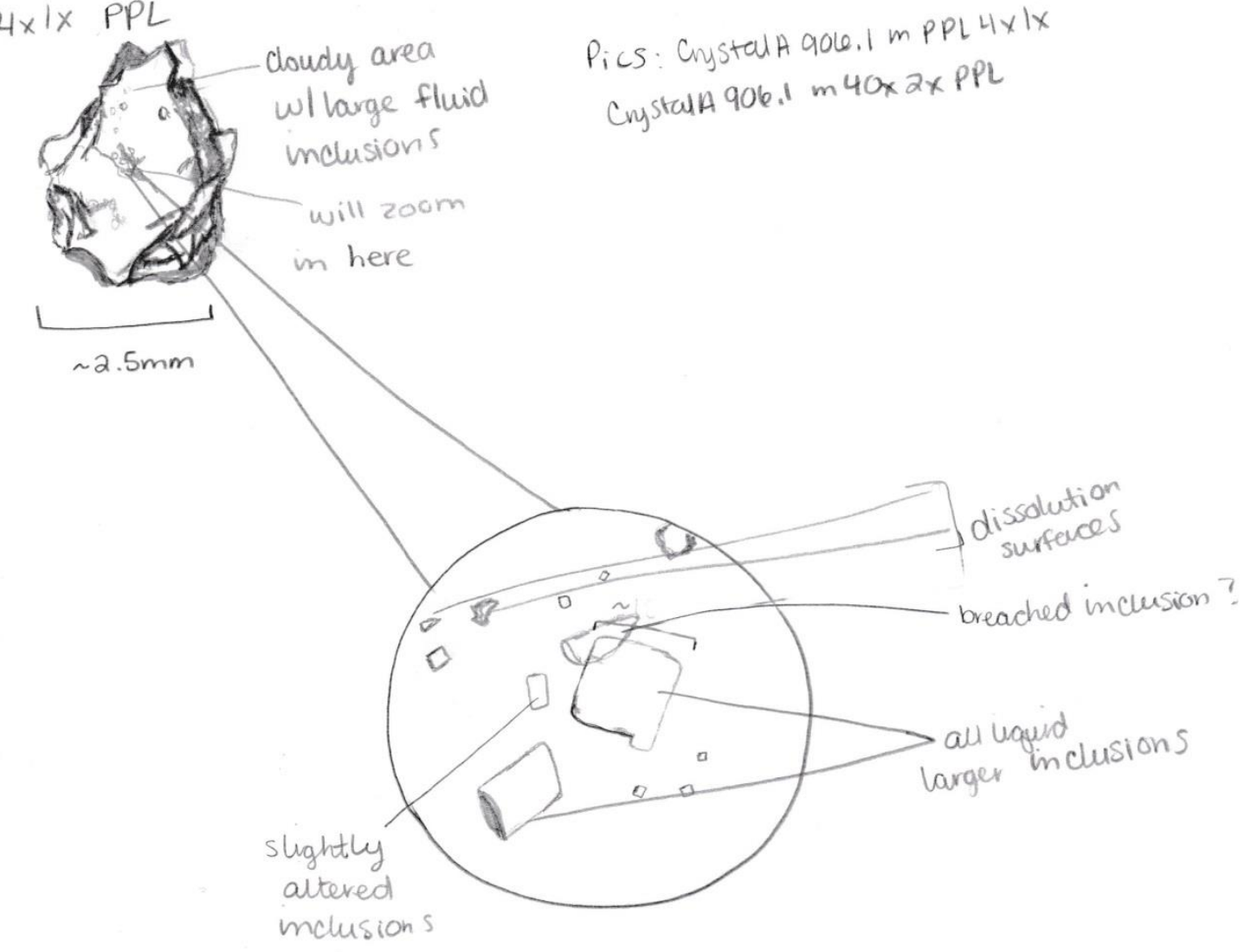


Eichenlaub, L.A., 2016

core: GESC2 (Carnduff 2)

$11 / 20115$

depth: $906.1 \mathrm{~m}$

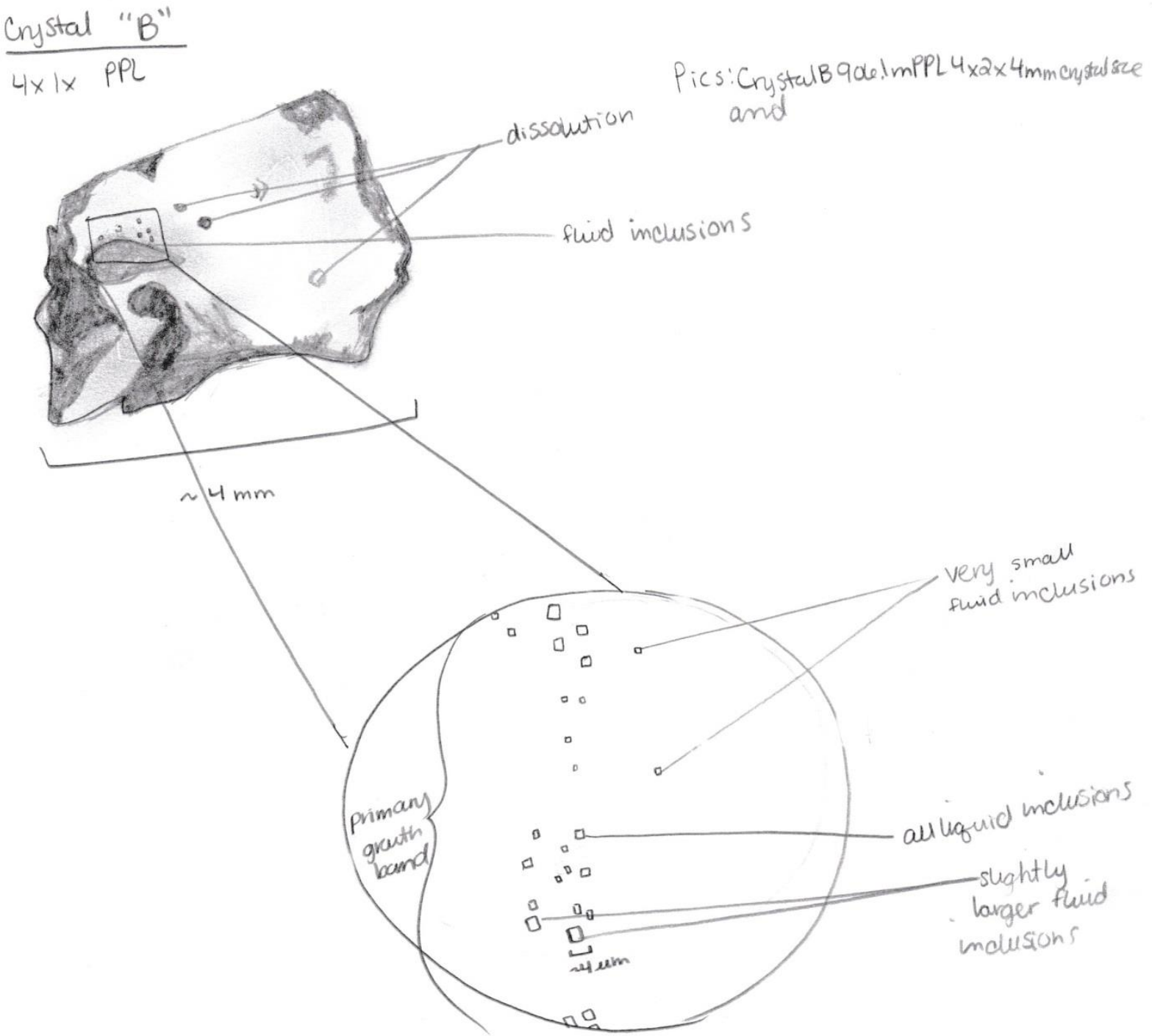


Eichenlaub, L.A., 2016

Core: GESC2 (Carnduff 2)

$11 / 21 / 15$

depth: $919.1 \mathrm{~m}$

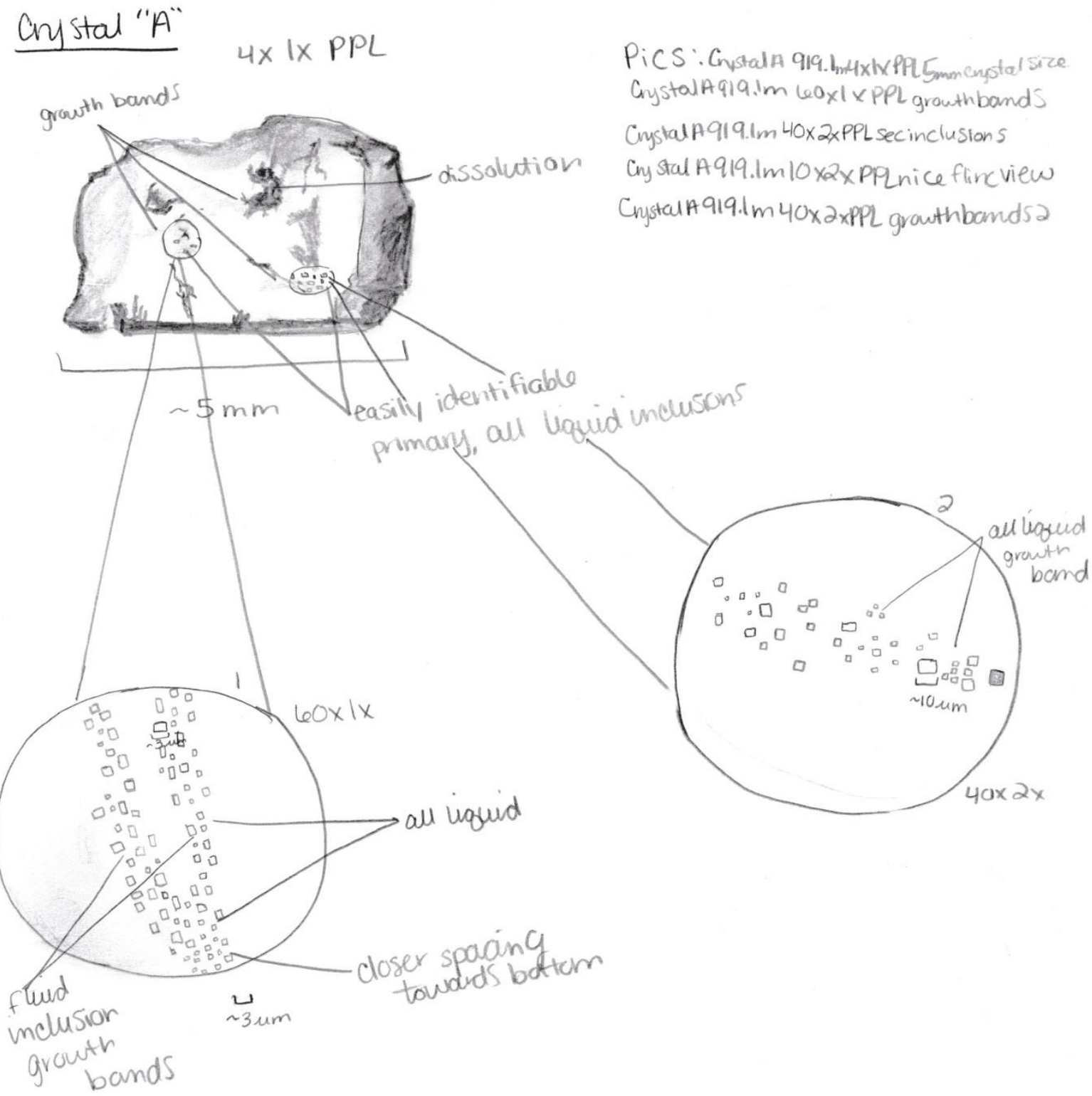


Eichenlaub, L.A., 2016

core: Gesc2 (Carnduff 2)

$11 / 23115$ depth: $919.1 \mathrm{~m}$

Crystal "C"

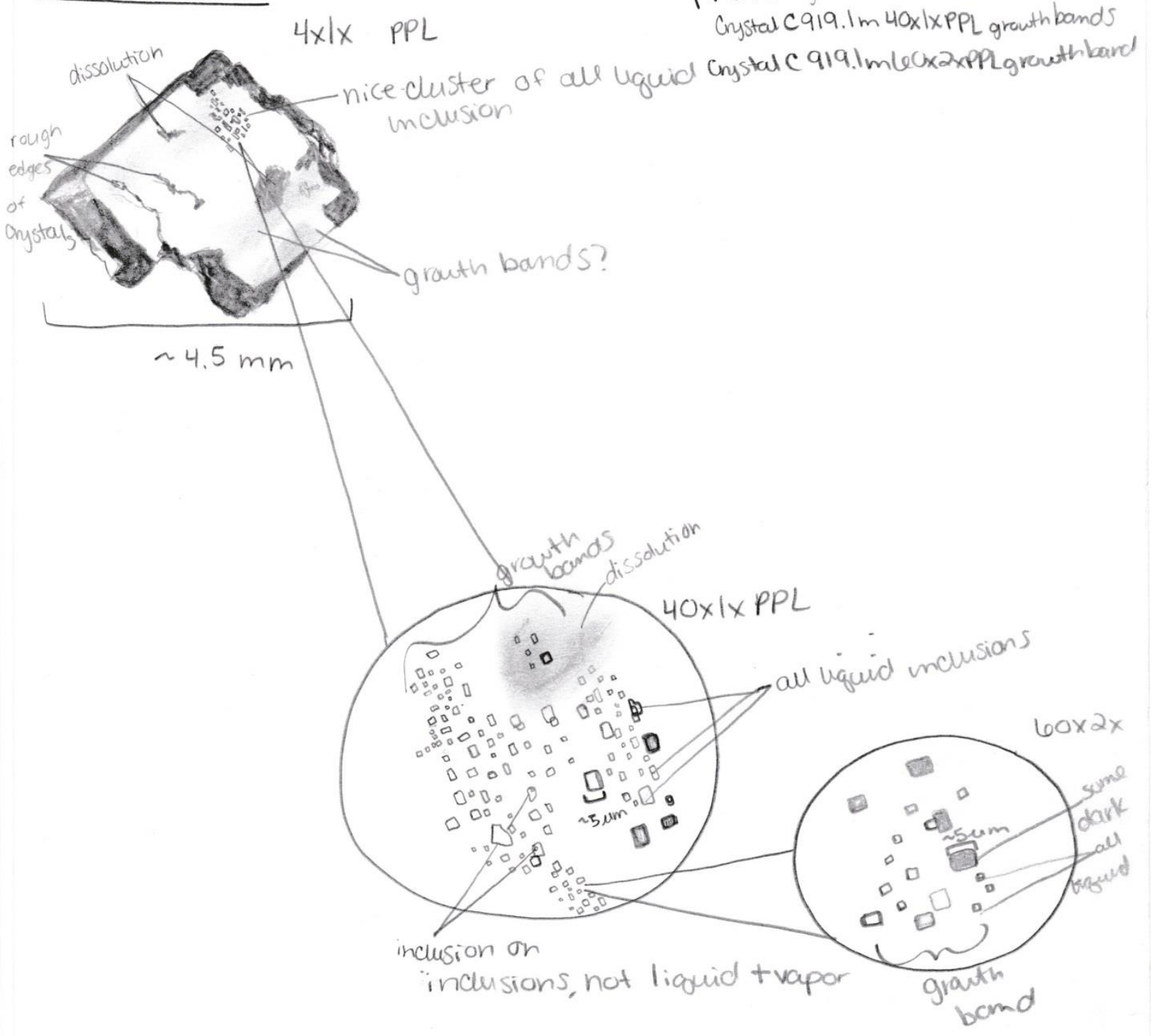

* Laser Ramam
sample 
Eichenlaub, L.A., 2016

Core: GESC2 (Carnduffa)

$11 / 23 / 15$

depth: $919.1 \mathrm{~m}$

Crystal "D"



Pics:

Cnystalp $919.1 \mathrm{~m} 4 \times 1 \times 3 \mathrm{~mm}$ crystal size Cystal $0919.1 \mathrm{~m} 60 \times 2 \times$ grew th band 
Eichenlaub, L.A., 2016

Core: GESCa (Canodutf 2)

11123115 deptri $919.1 \mathrm{~m}$

Crystal "E"



Pics:

Crystale 9191 Im $4 \times 1 \times P$ Pl 4 mancystal size

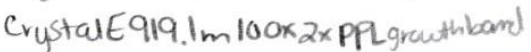


Eichenlaub, L.A., 2016




Eichenlaub, L.A., 2016

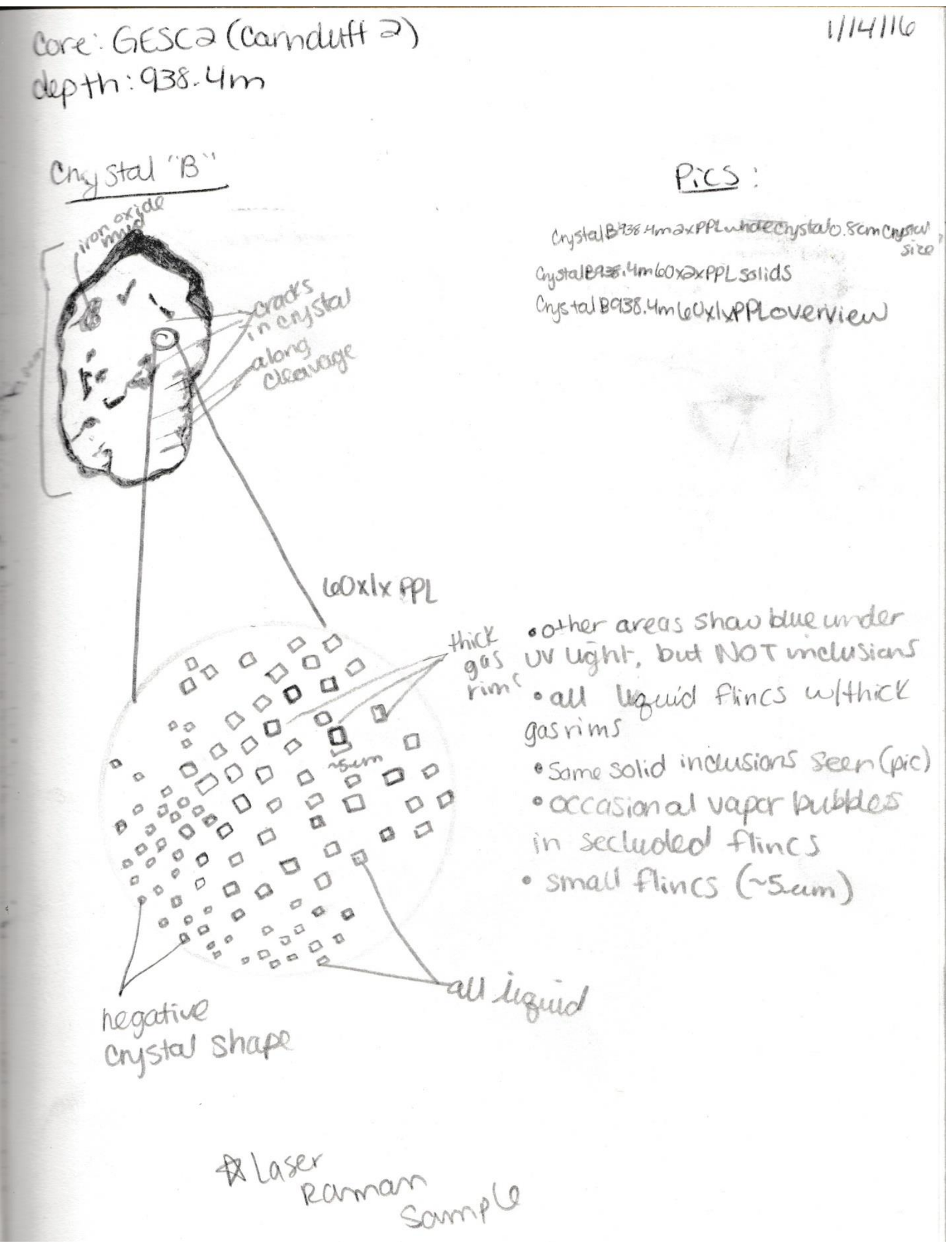


Eichenlaub, L.A., 2016

Core: GESC $ə$ (Carnduffl)

$1 / 1441 / 6$

depth. $938.4 \mathrm{~m}$

Cnstal "C"

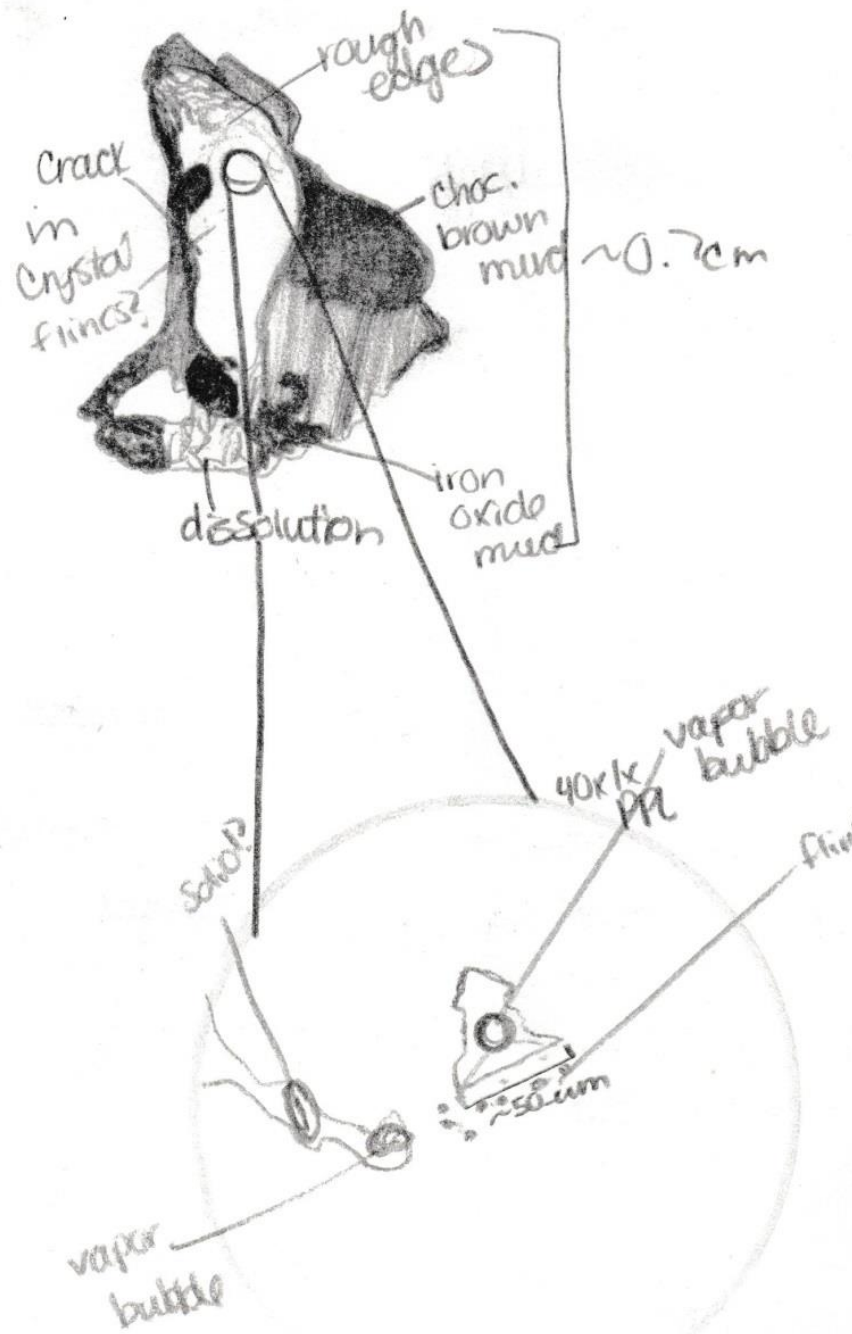

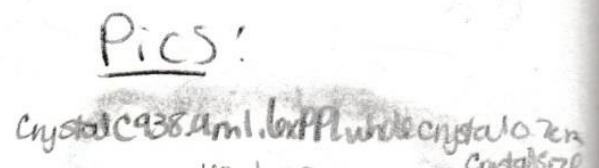
Cnystalc938.4m 40x lxpp averview cinglise

- Some areas turn blue under uv light, but not in flines r

- flincs are rare, those seen are mostly all uquid withich gas rims

- Idk inclusions are seen ulsolids + vapor butbles

- this is kind of a chappy sample 


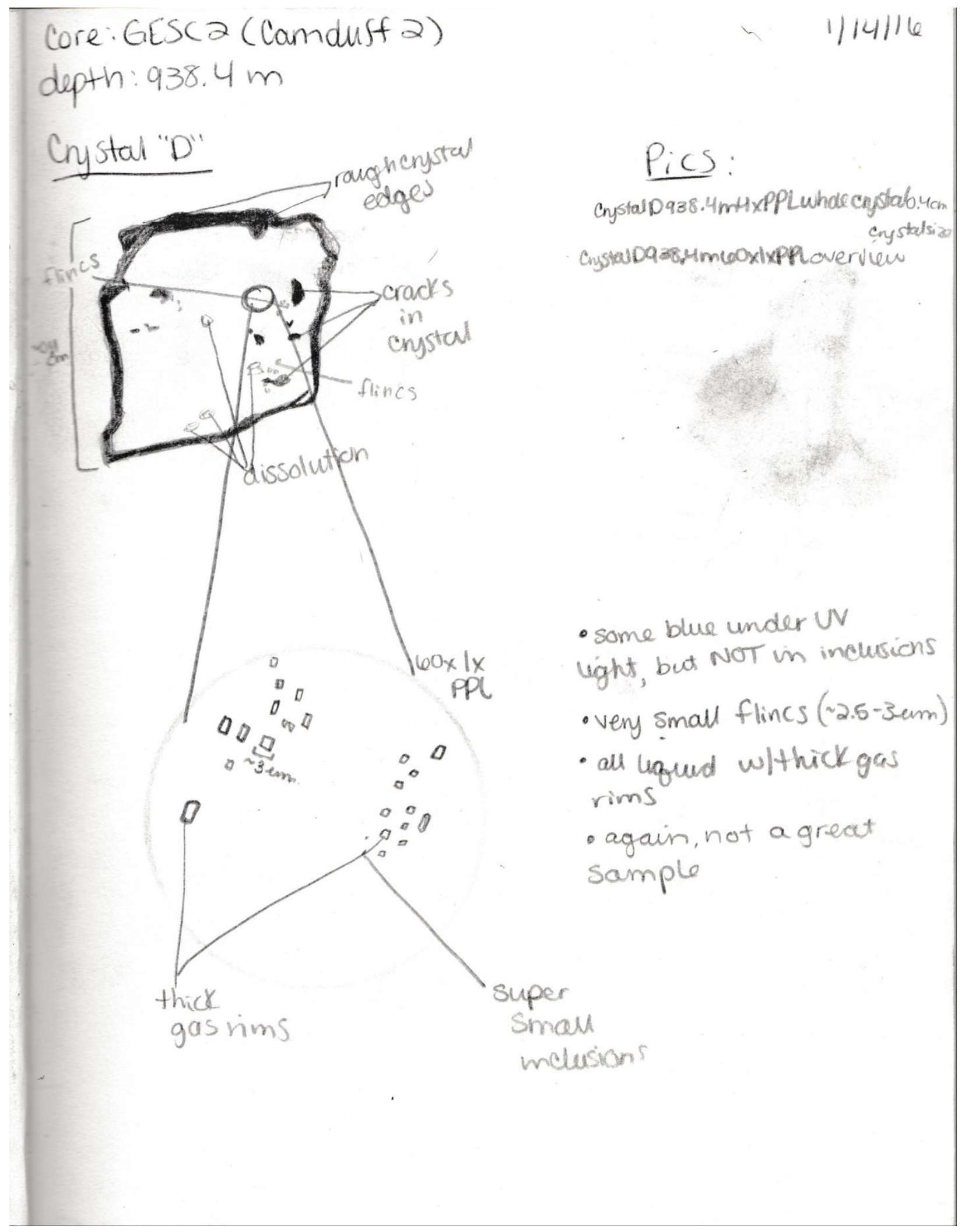





Liquid-solid inclusions at a depth of 815.5 meters in PPL (left) and UV light (right). Note the blue and yellow fluorescence.
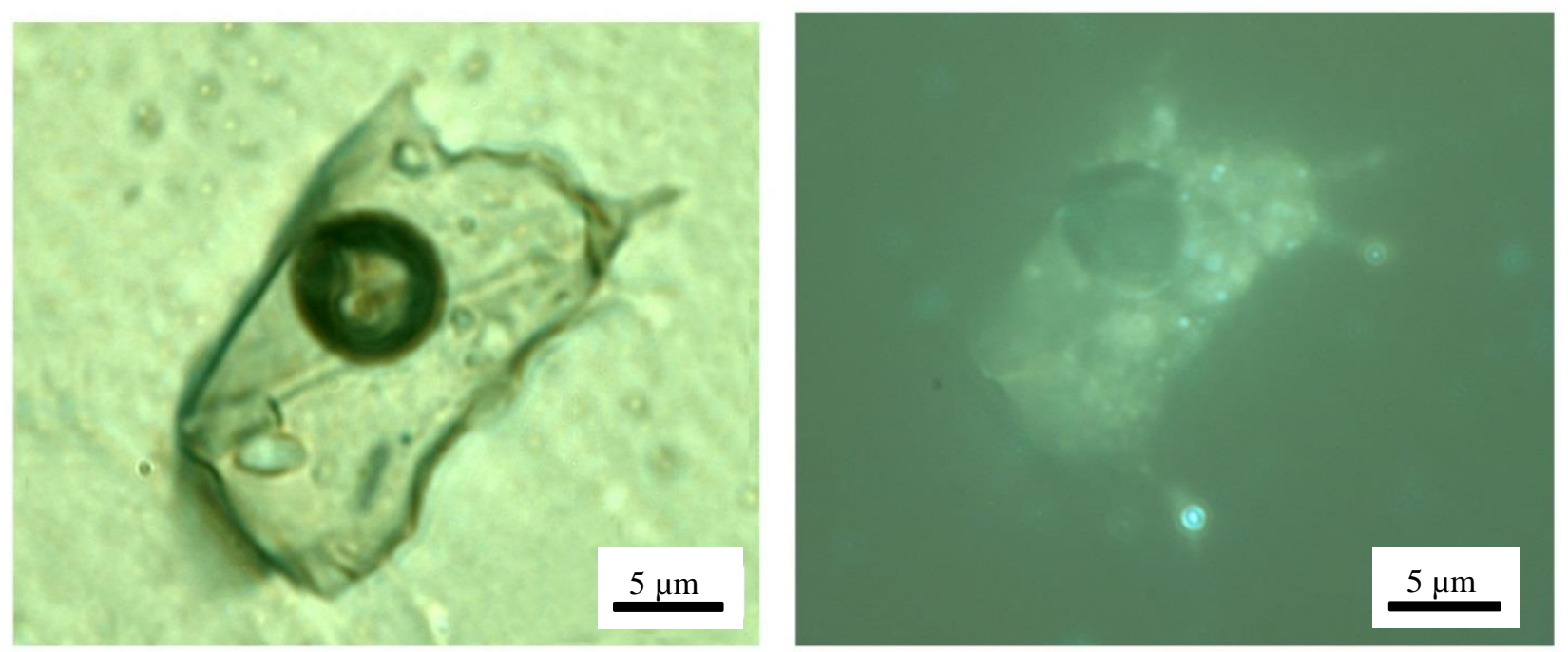

An isolated inclusion containing liquid, solids, and gas (vapor bubble) at a depth of 819.6 meters showing yellow fluorescence under UV light (right). Smaller surrounding inclusions show a blue fluorescence. 

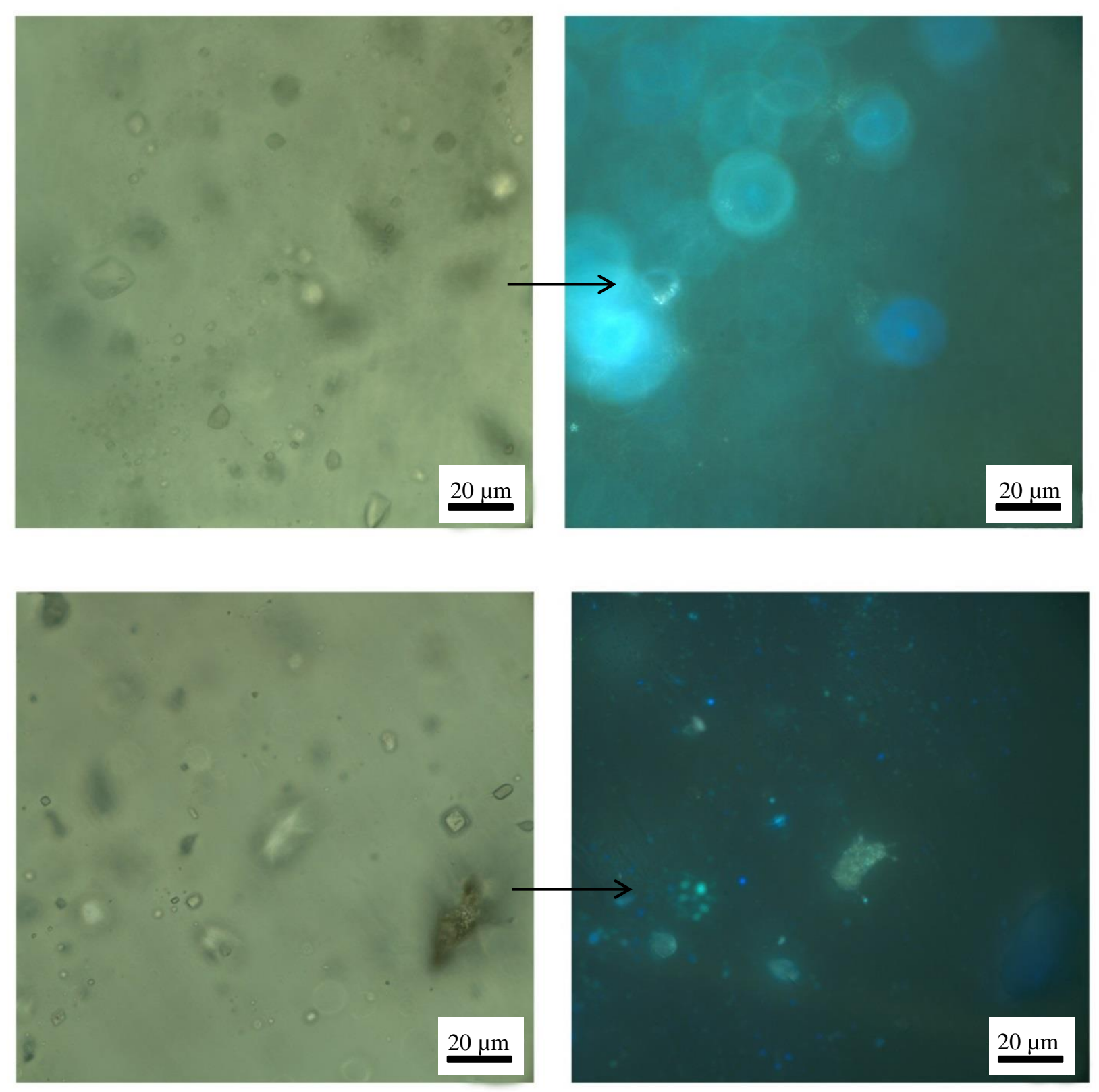

Various inclusions at a depth of 819.6 meters showing yellow and blue fluorescence (images on right). Note that the smaller, primary inclusions flu oresce blue, while the larger, isolated inclusions fluoresce yellow. 
Eichenlaub, L.A., 2016

Appendix D:

Microthermometric Data 


\section{$887 \mathrm{~m}$}



\section{Freezing Melting,}

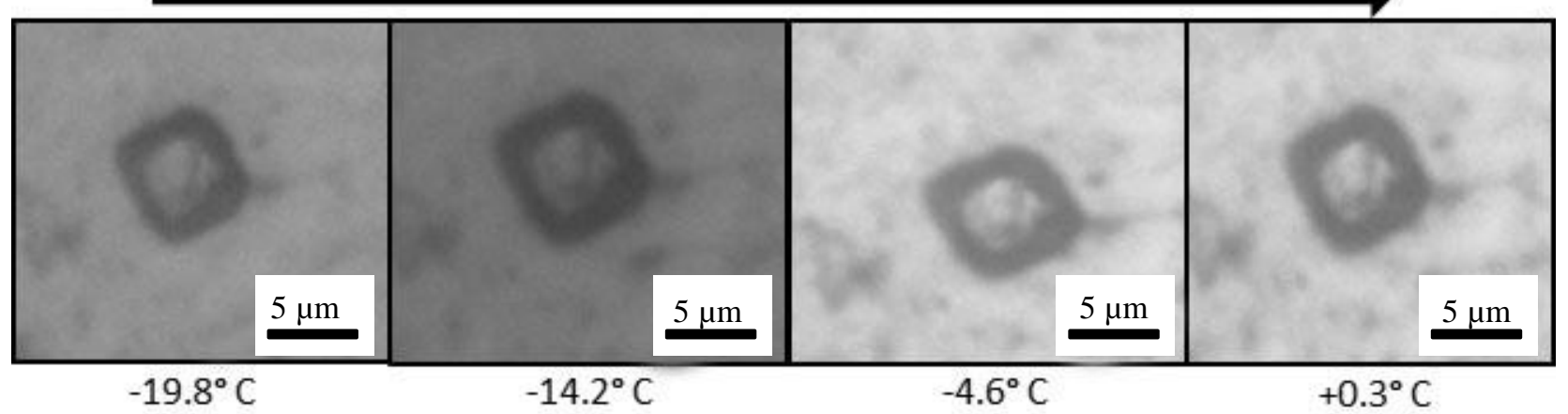

Melting

Images of a fluid inclusion at various temperatures during a failed freezing-melting run. This fluid inclusion was found in a bed at a depth of 887.0 meters. All fluid inclusions analyzed failed to freeze. 
Eichenlaub, L.A., 2016

Appendix E:

Laser Raman Spectroscopy Data 
Eichenlaub, L.A., 2016

Laser Raman Data for All Liquid Inclusions

\begin{tabular}{|c|c|c|}
\hline Depth (m) & Peaks in $\sim 100-2000$ & $\begin{array}{l}\text { Whole Spectra Peaks }(\sim 100- \\
4000)\end{array}$ \\
\hline 659.5 & & $3400,1640,1020,490$ \\
\hline A & $\begin{array}{c}1640,1060-1200(\mathrm{~b}), 1030,1017,990,984,488,1030(\mathrm{~b}) \\
660(\mathrm{~s}), 620(\mathrm{~s}), 358(\mathrm{~s})\end{array}$ & \\
\hline $\mathrm{B}$ & $\begin{array}{c}1640,1470,982,870,865,489,236,230,351 \text { (b from } \\
325-270)\end{array}$ & \\
\hline $\mathrm{C}$ & $1640,1100-1200(b)$ & \\
\hline $\mathrm{D}$ & $1640,1020,1017,984,963(\mathrm{~s}), 490$ & \\
\hline $\mathrm{E}$ & $1640,1017,982,488$ & \\
\hline 805.6 & & $3400,1650,490(\mathrm{~s}), 450$ \\
\hline A & $1640,982(\mathrm{~s})$ & \\
\hline $\mathrm{B}$ & $1640,1017,630$ & \\
\hline $\mathrm{C}$ & $1640,490,236,230$ & \\
\hline $\mathrm{D}$ & $1640,1017,630,490$ & \\
\hline $\mathrm{E}$ & $1640,982(\mathrm{~s}), 490,365,361,239,233$ & \\
\hline 815.5 & & $\begin{array}{c}1.3400,1640, \\
2.3400,2000(s), 1017,490\end{array}$ \\
\hline A & 1650,489 & \\
\hline $\mathrm{B}$ & $1640(\mathrm{~s}), 1017,420$ & \\
\hline $\mathrm{C}$ & $1640,1164,1131,1114,1020,678,630,613,502,422$ & \\
\hline 819.6 & & $\begin{array}{l}3400,1650,1317,690,640,411 \\
245,224\end{array}$ \\
\hline A & $1650,1102(\mathrm{~s}), 502$ & \\
\hline $\mathrm{B}$ & $1640,1446,640,517,490,400,200(s), 190(s), 145$ & \\
\hline 841.7 & & $3400,1650,490$ \\
\hline A & $1650,1140(\mathrm{~s}), 775$ & \\
\hline B & 1650,490 & \\
\hline $\mathrm{C}$ & 1640,490 & \\
\hline 862.4 & & $3400,1640,498,145$ \\
\hline A & $1321,660-700(b), 611,501,409,302,225$ & \\
\hline B & $\begin{array}{l}1604,1470,1260,1240,1181,1111,1035,1020,986, \\
900,705,640,430-470 \text { (b) }\end{array}$ & \\
\hline $\mathrm{C}$ & $1325,615,419,250,230$ & \\
\hline $\mathrm{D}$ & $1640(\mathrm{~s}), 1180,1020,700,680,640,620,145$ & \\
\hline 887.0 & & $\begin{array}{c}3400,1640, \\
1160,1143,1131,1020,691,630 \\
624,502,, 432,420\end{array}$ \\
\hline $\mathrm{A}$ & $\begin{array}{c}1640,1172,1160,1143,1131,1031,1020,691,678,640, \\
630,624,612,502,490,432,420\end{array}$ & \\
\hline B & $\begin{array}{l}1640,1040-1200(\mathrm{~b}), 1020,490,360,260-300,240, \\
233(\mathrm{~s}), 172\end{array}$ & $3400,1640,360,290$ \\
\hline $\mathrm{C}$ & 1640, $1132(\mathrm{~s}), 1020,490,360,220-245(\mathrm{~b}), 189$ & \\
\hline $\mathrm{D}$ & $\begin{aligned} 1640,1420,1162, & 1131,1039,1020,1017,679,630 \\
& 612,502,420\end{aligned}$ & $\begin{array}{l}3400,1640,1162,1132,1020, \\
679,630,502,420\end{array}$ \\
\hline $\mathrm{C}$ & $1640,490,340-390,235,190$ & \\
\hline 906.1 & & $3400,1640,(490 ?)$ \\
\hline $\mathrm{A}$ & $1650,1321,1020-1200(\mathrm{~b}), 490,420,277$ & \\
\hline
\end{tabular}


Eichenlaub, L.A., 2016

\begin{tabular}{|c|c|c|}
\hline $\mathrm{B}$ & 1640,490 & \\
\hline $\mathrm{C}$ & $1640,490(1100-1200 ?)$ & \\
\hline 919.1 & & 3400,1640 \\
\hline A & 1640,490 & \\
\hline B & $1640,986(\mathrm{~s}), 490$ & \\
\hline $\mathrm{C}$ & 1640,490 & \\
\hline $\mathrm{D}$ & $\begin{array}{c}1640,1175,1162,1131,1111,1031,1020,690,678, \\
643,630,611,501,432,421,237,190(s), 183,172 \\
136,126\end{array}$ & \\
\hline $\mathrm{E}$ & 1640,490 & \\
\hline $\mathrm{F}$ & $\begin{array}{c}1640,1617,1421,1370,1300,1285,1265,1225,1198, \\
1175,1117,1080,1060,1020,986,946,640,520\end{array}$ & \\
\hline 938.4 & & $\begin{array}{c}3400,1640 \\
3400,2900,1660,1440,1300 \\
860,490,380,188,140\end{array}$ \\
\hline A (rim) & 1330 (b), 490, 338-369 & \\
\hline B & $\begin{array}{c}1660,1600,1439,1301,1132(\mathrm{~s}), 1087,860,640,520 \\
488,188,147\end{array}$ & \\
\hline $\mathrm{C}$ & $\begin{array}{c}1632,1438,1371,1296,1243(\mathrm{~s}), 1219(\mathrm{~s}), 1195(\mathrm{~s}), \\
1160(\mathrm{~s}), 1110,1064,939,639,422,188,142\end{array}$ & \\
\hline $\mathrm{D}$ & $\begin{array}{c}1633,1438,1372,1296,1248(\mathrm{~s}), 1223(\mathrm{~s}), 1191(\mathrm{~s}), \\
1161(\mathrm{~s}), 1110,1064,939,630(\mathrm{~s}), 189,125\end{array}$ & \\
\hline Gorbea Pink (pH 1.6) & $\begin{array}{c}1640,1040-1200,986,880,600-640(b), 490,440-480 \\
\text { (b) }\end{array}$ & $3400,1640,986,600,450$ \\
\hline Gorbea Blue (pH 1.8) & $\begin{array}{c}1640,1060-1160(b), 986,880,750,600-650(b), 490, \\
460\end{array}$ & $3400,1640,986,600,450$ \\
\hline Aerodrome (pH 1.8) & 1640,986 & $3400,1640,986$ \\
\hline Gneiss Lake (pH 1.4) & $986,596(\mathrm{~s})$ & 3400,986 \\
\hline & & \\
\hline & & \\
\hline
\end{tabular}

$\mathrm{S}=$ small or slight, $\mathrm{b}=$ broad bump

Laser Raman Data for Liquid-Solid Inclusions

\begin{tabular}{|c|c|c|}
\hline Depth (m) & Peaks in $\sim 100-2000$ & $\begin{array}{l}\text { Whole Spectra Peaks }(\sim 100- \\
4000)\end{array}$ \\
\hline 815.5 & & $\begin{array}{c}1.3400,1640 \\
2.3400,2000(\mathrm{~s}), 1017,490\end{array}$ \\
\hline A & $1640,1131,1117,1020,631,610,499,490,420$ & \\
\hline B & $\begin{array}{c}1640,1153,1140,1131,1111,1020,826,779,784,679, \\
630,611,596,489,421\end{array}$ & \\
\hline $\mathrm{C}$ & $\begin{array}{c}1640(\mathrm{~s}), 1156(\mathrm{~s}), 1129,1017,710,707,675,628 \\
610,498,417\end{array}$ & \\
\hline 841.7 & & $3400,1650,490$ \\
\hline A & $1162,1132,1020,679,630,610,503,489$ & \\
\hline
\end{tabular}


Eichenlaub, L.A., 2016

Eichenlaub, L.A., 2016




Eichenlaub, L.A., 2016
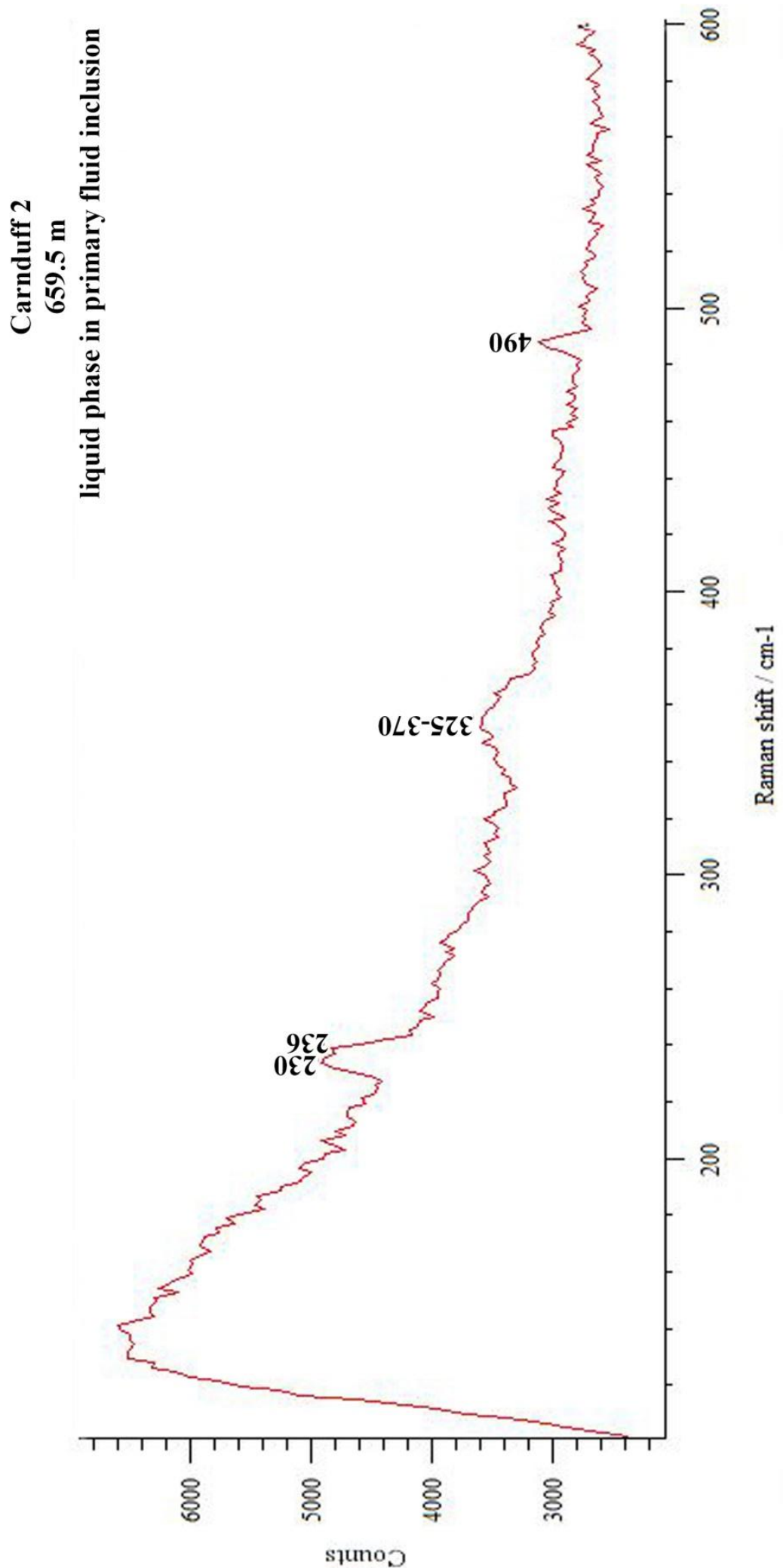
Eichenlaub, L.A., 2016

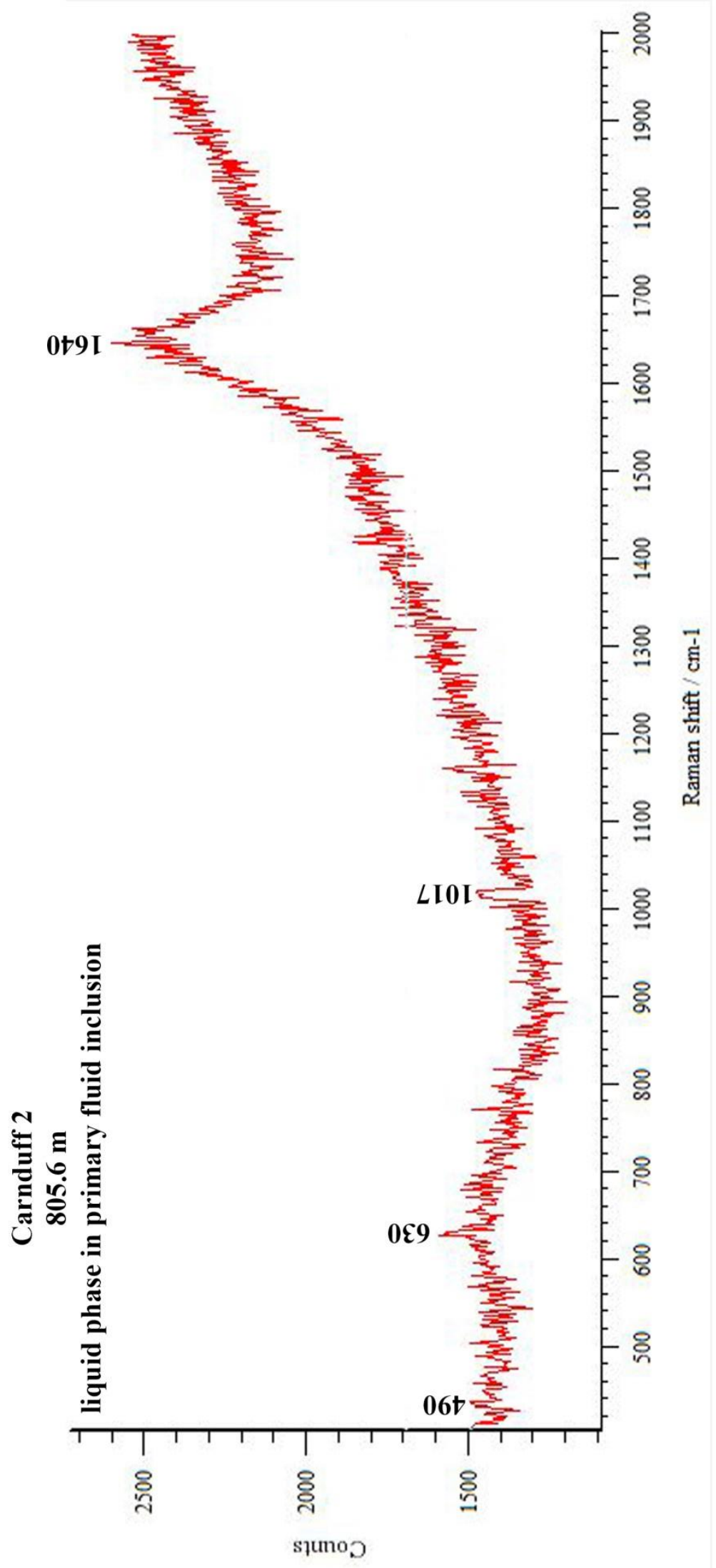


Eichenlaub, L.A., 2016

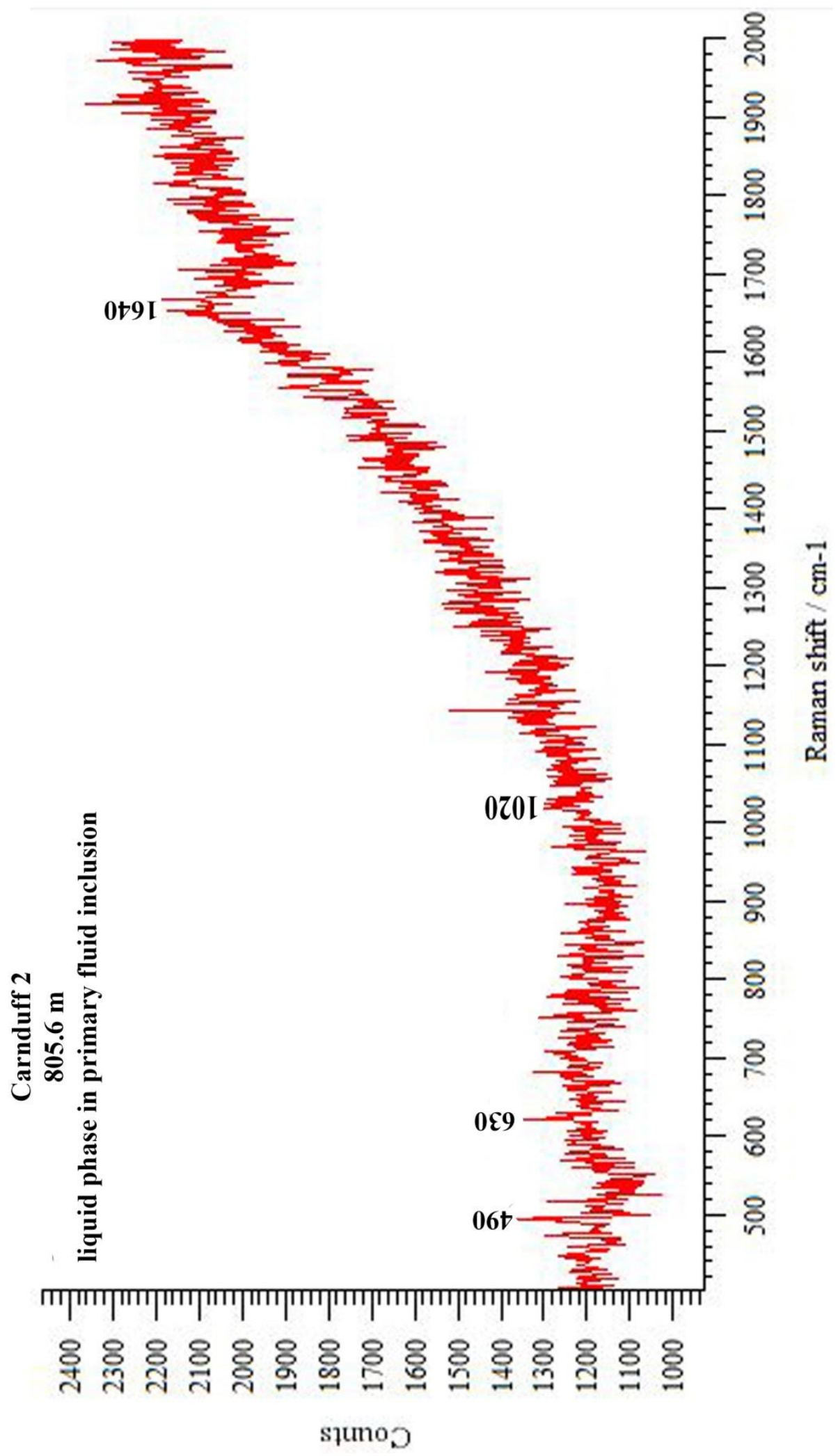


Eichenlaub, L.A., 2016

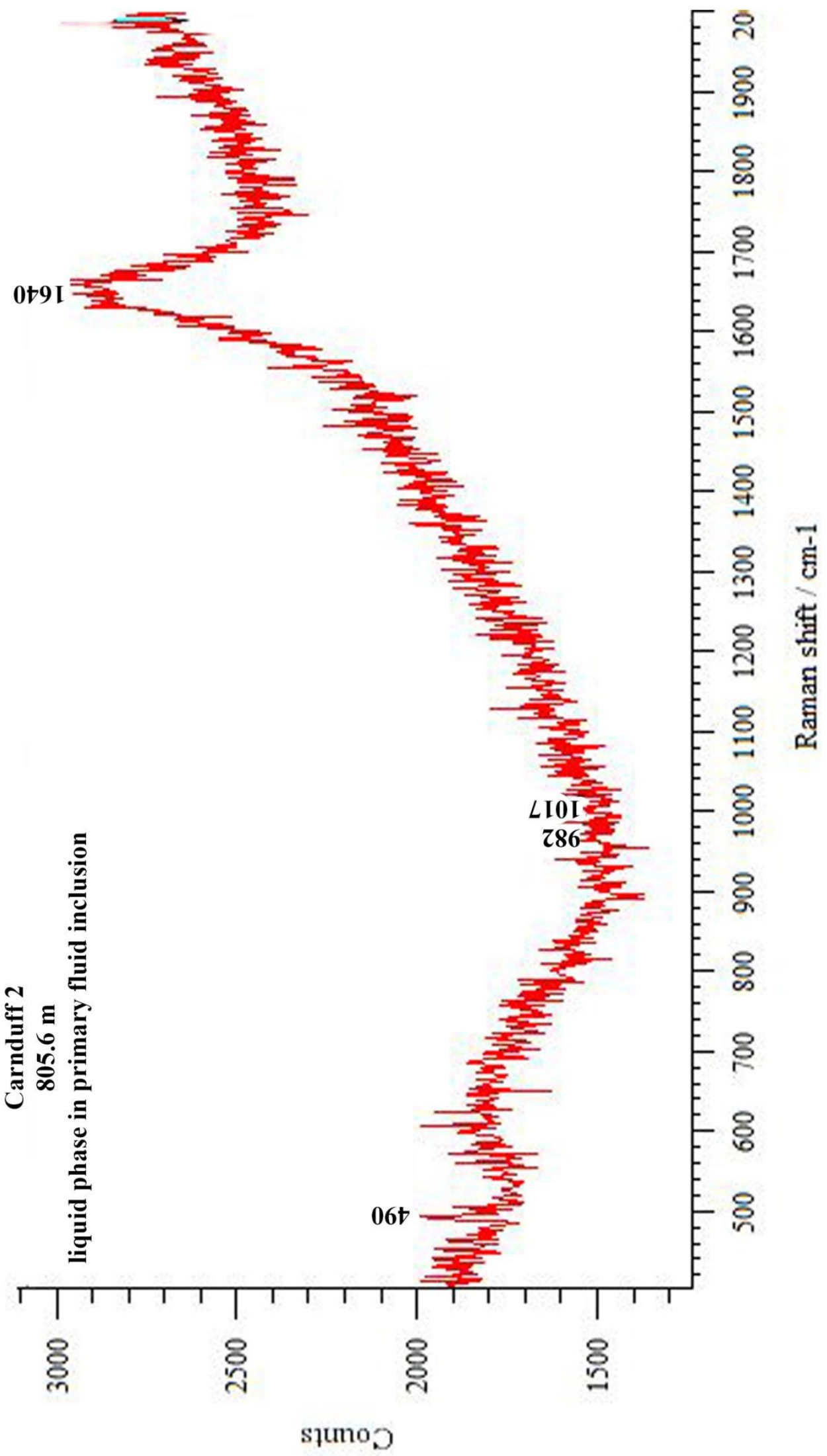


Eichenlaub, L.A., 2016

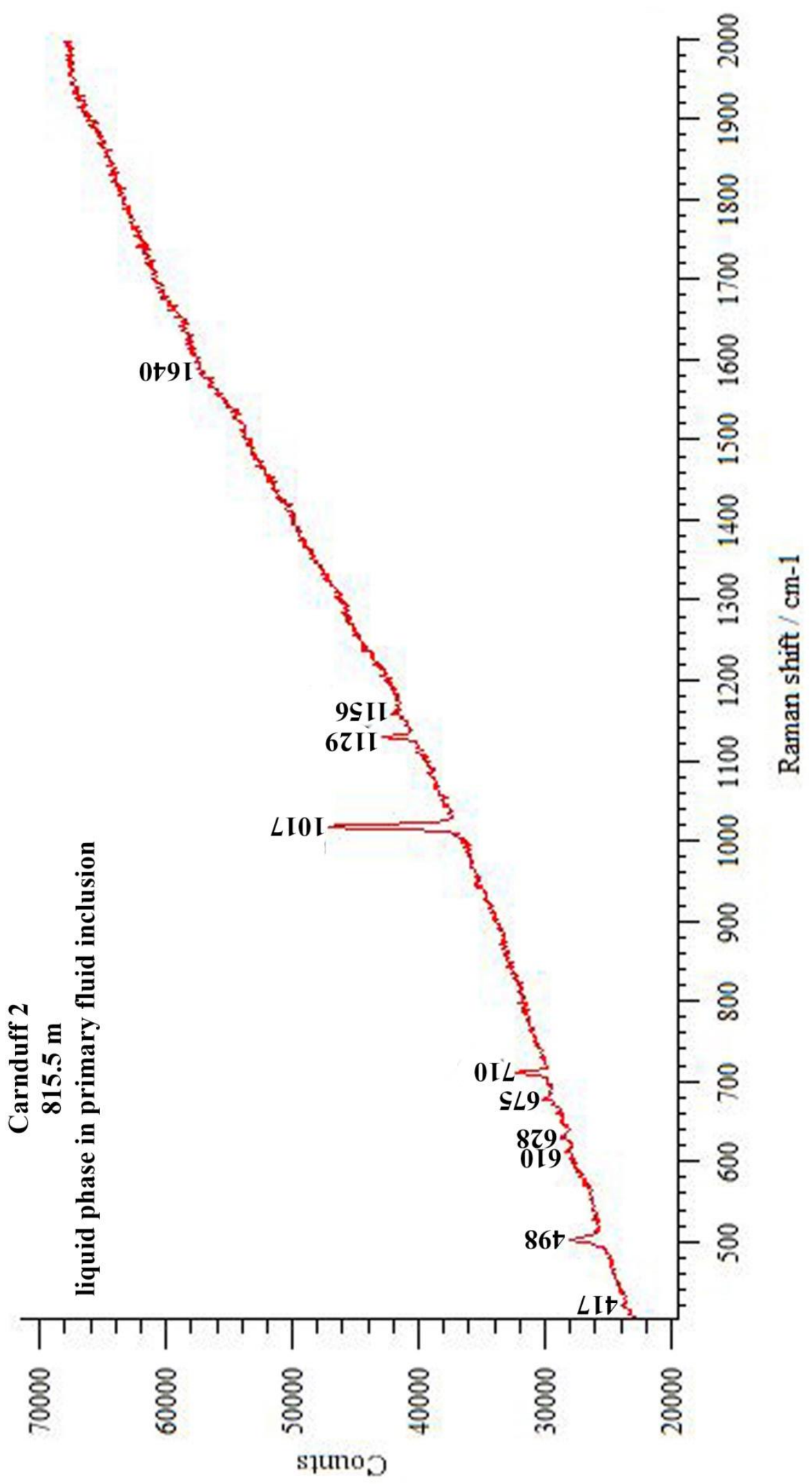


Eichenlaub, L.A., 2016

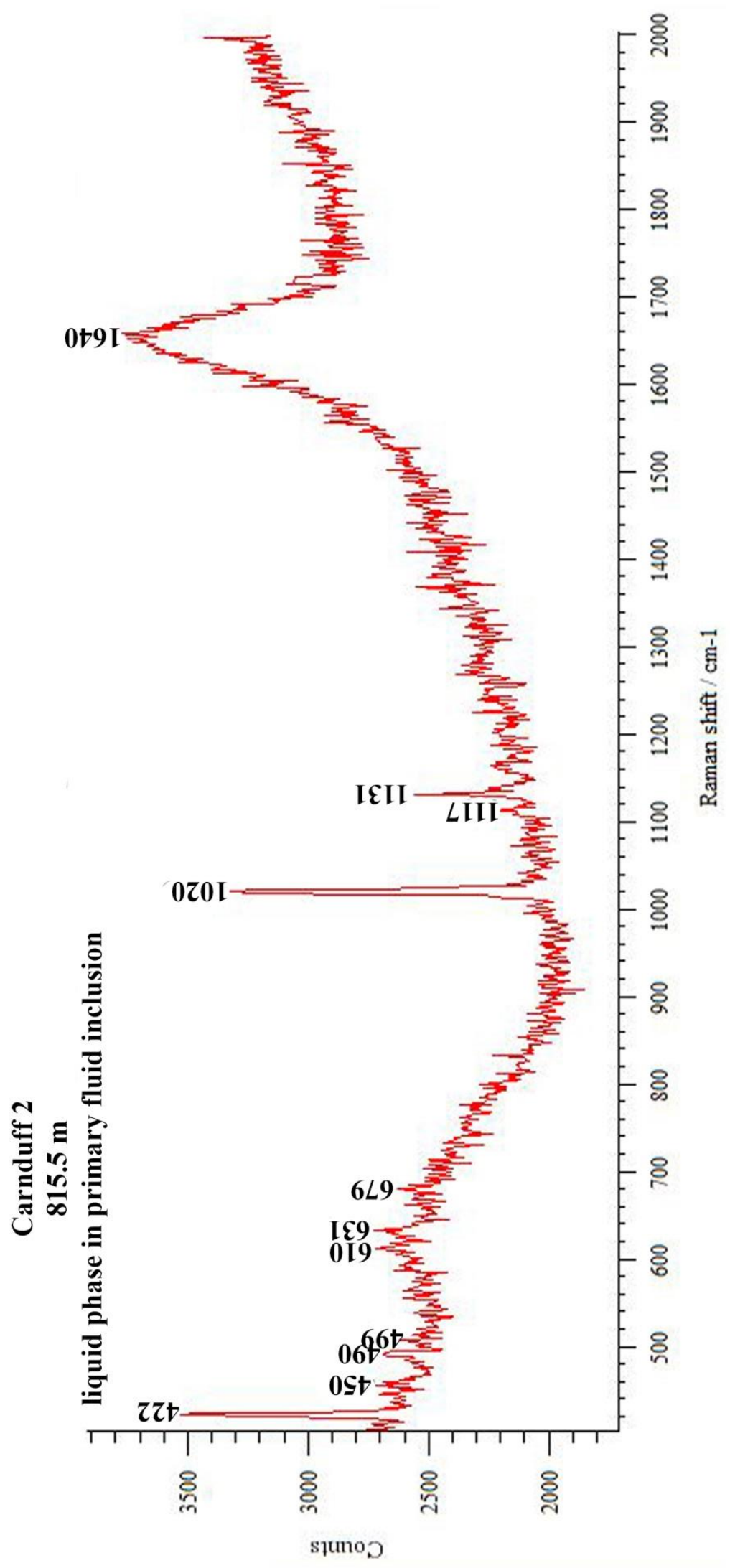


Eichenlaub, L.A., 2016




Eichenlaub, L.A., 2016




Eichenlaub, L.A., 2016

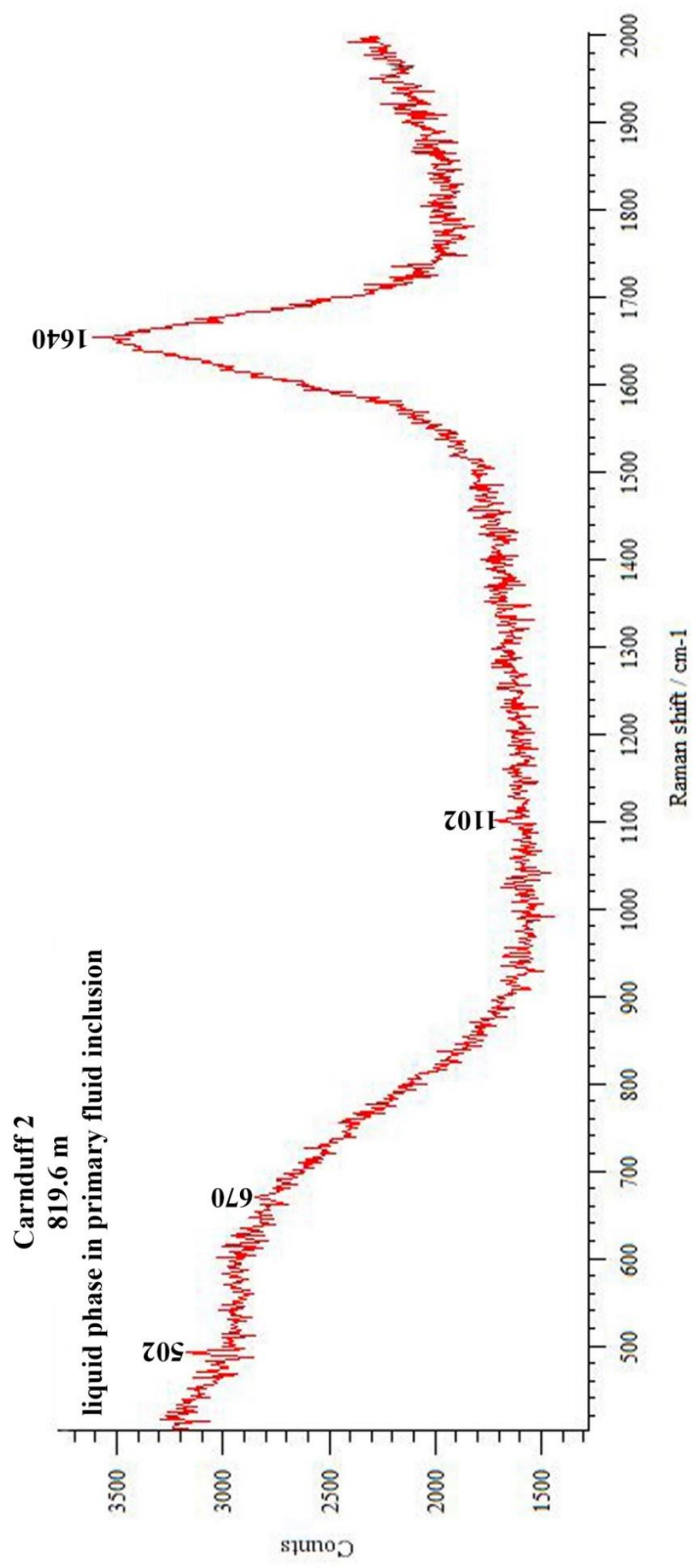


Eichenlaub, L.A., 2016
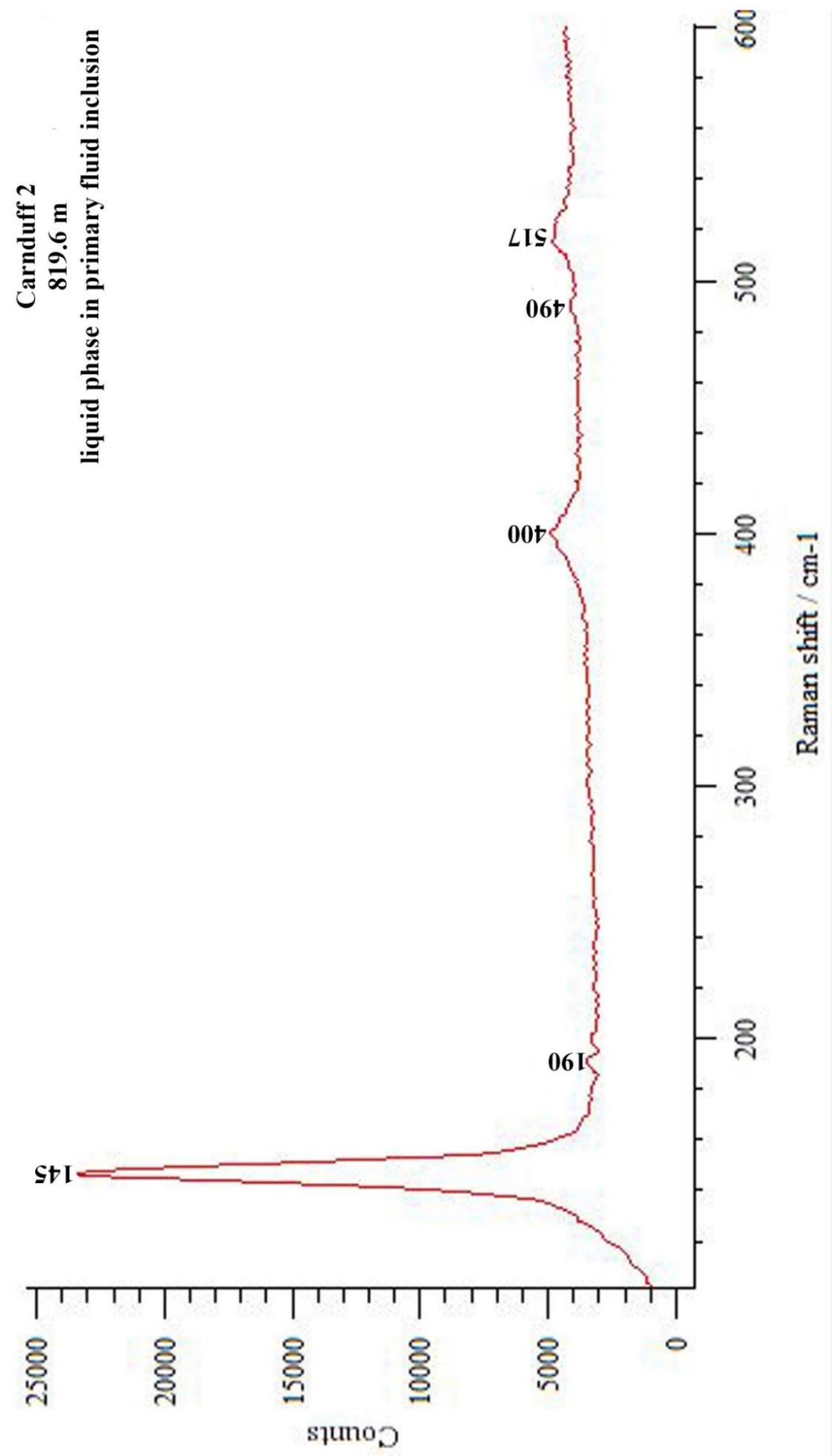
Eichenlaub, L.A., 2016

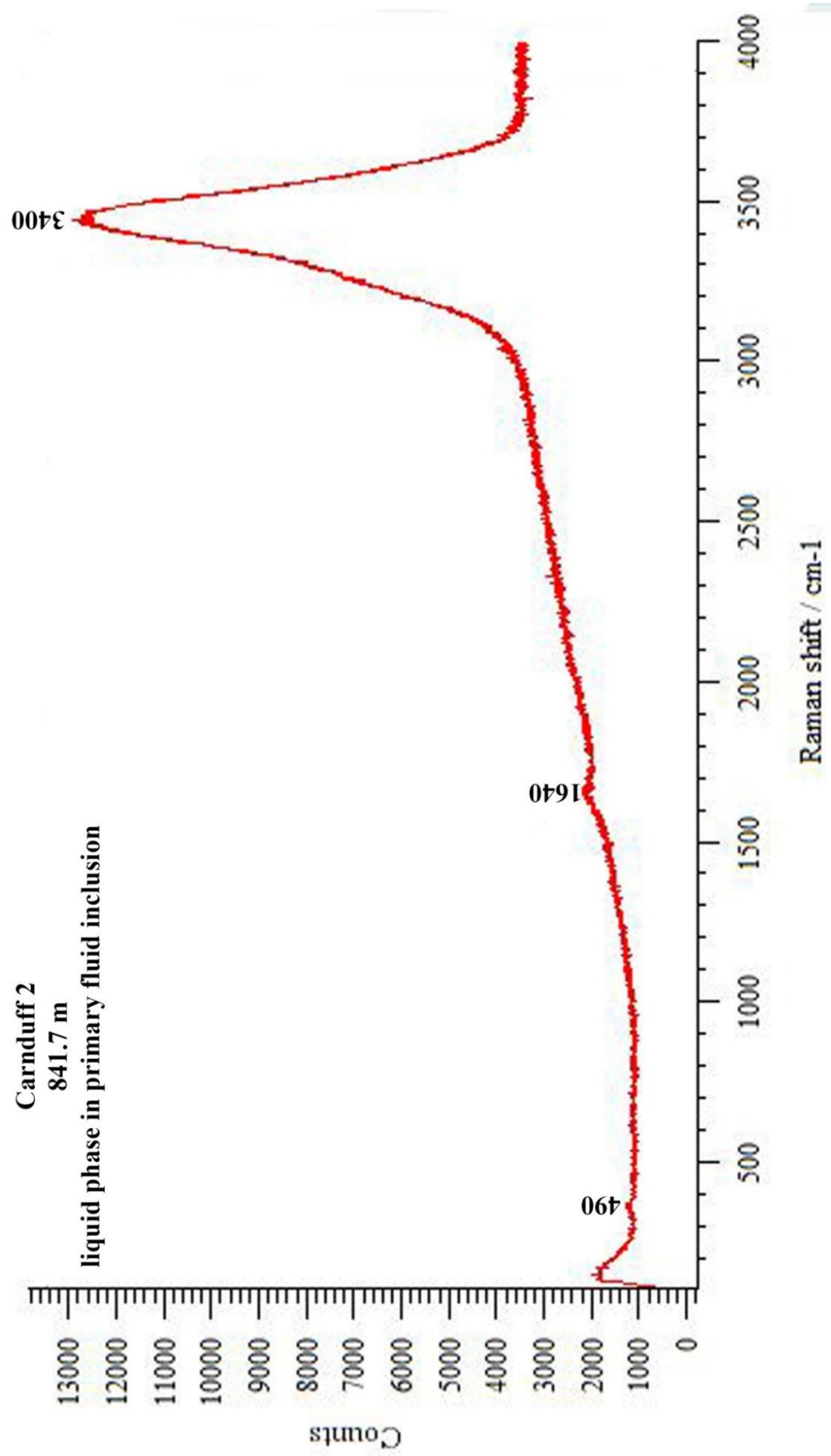


Eichenlaub, L.A., 2016




Eichenlaub, L.A., 2016

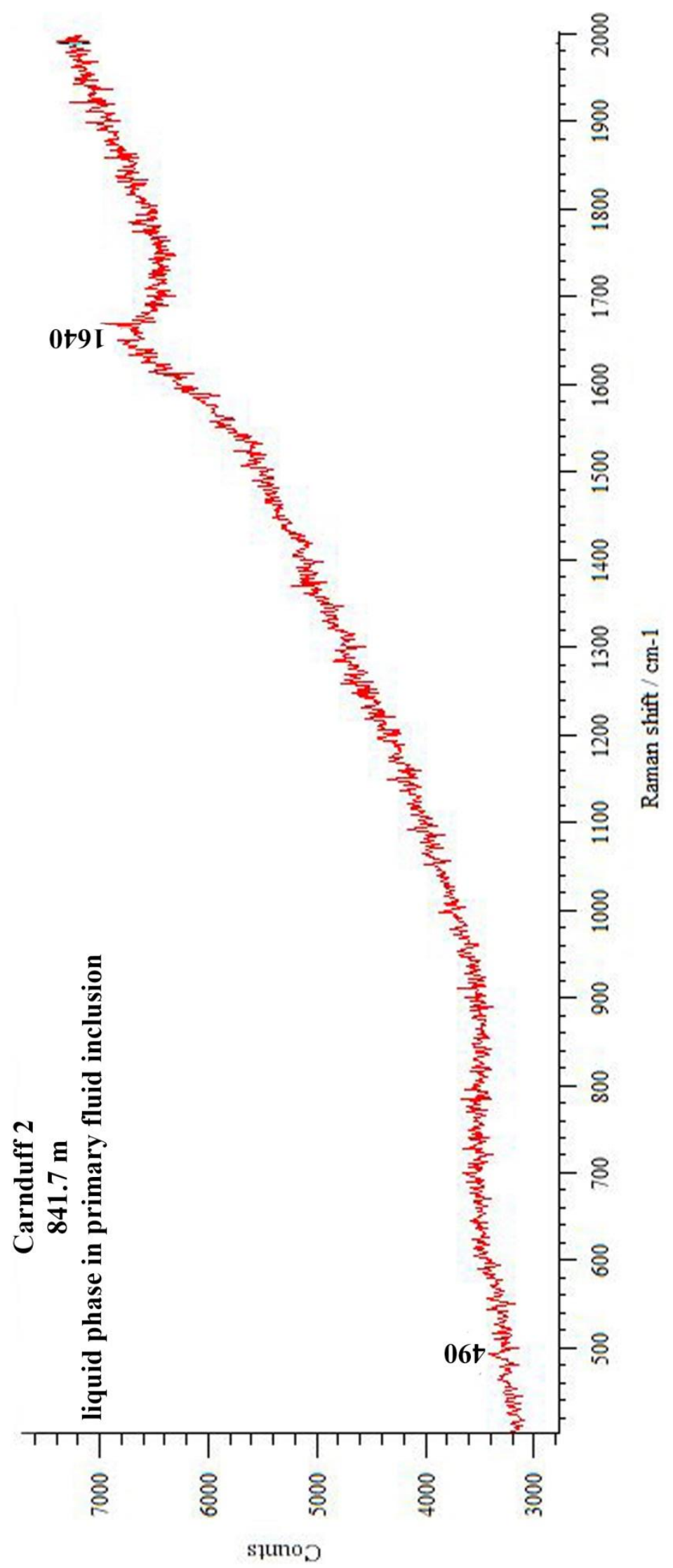


Eichenlaub, L.A., 2016

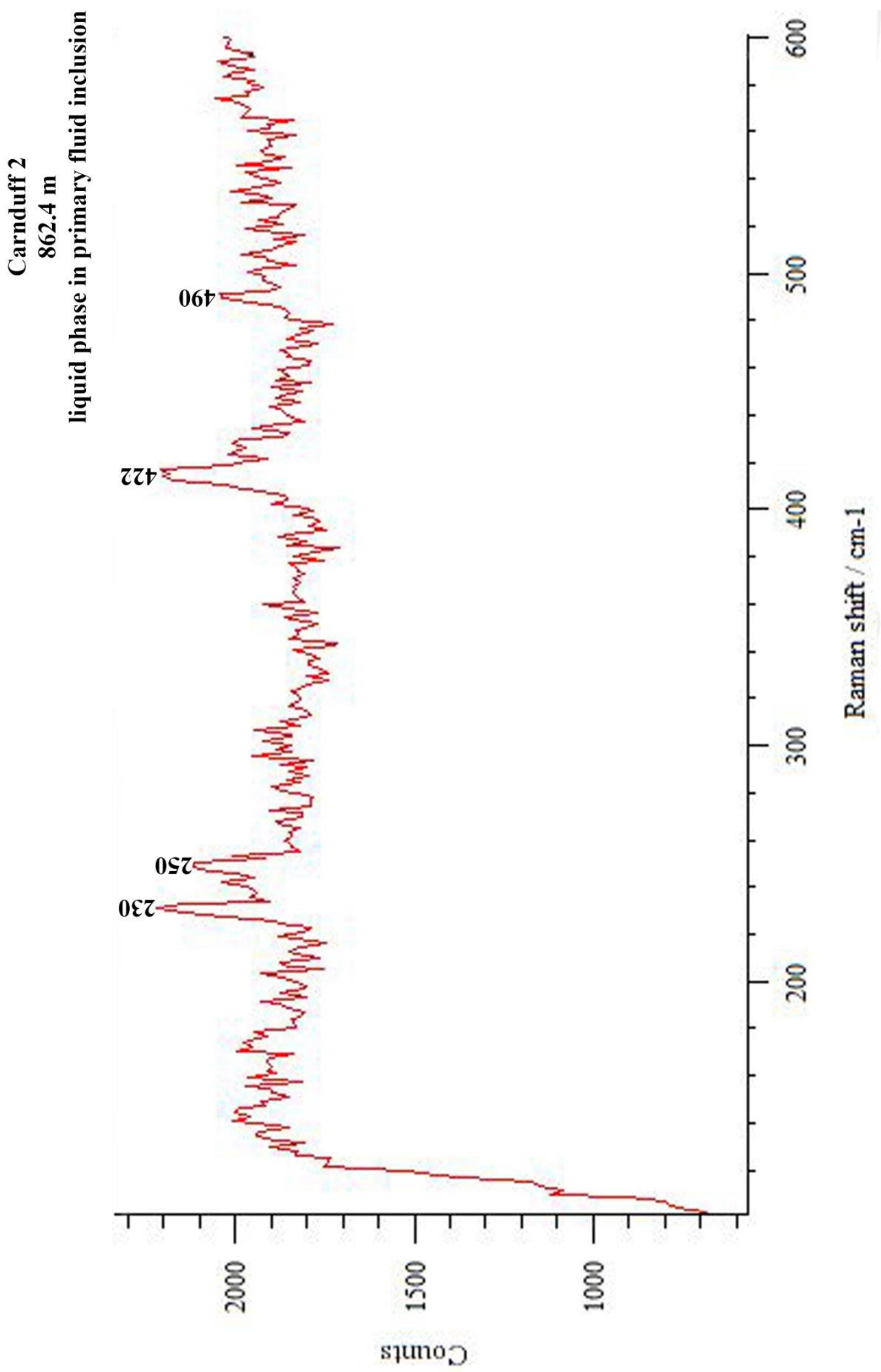


Eichenlaub, L.A., 2016

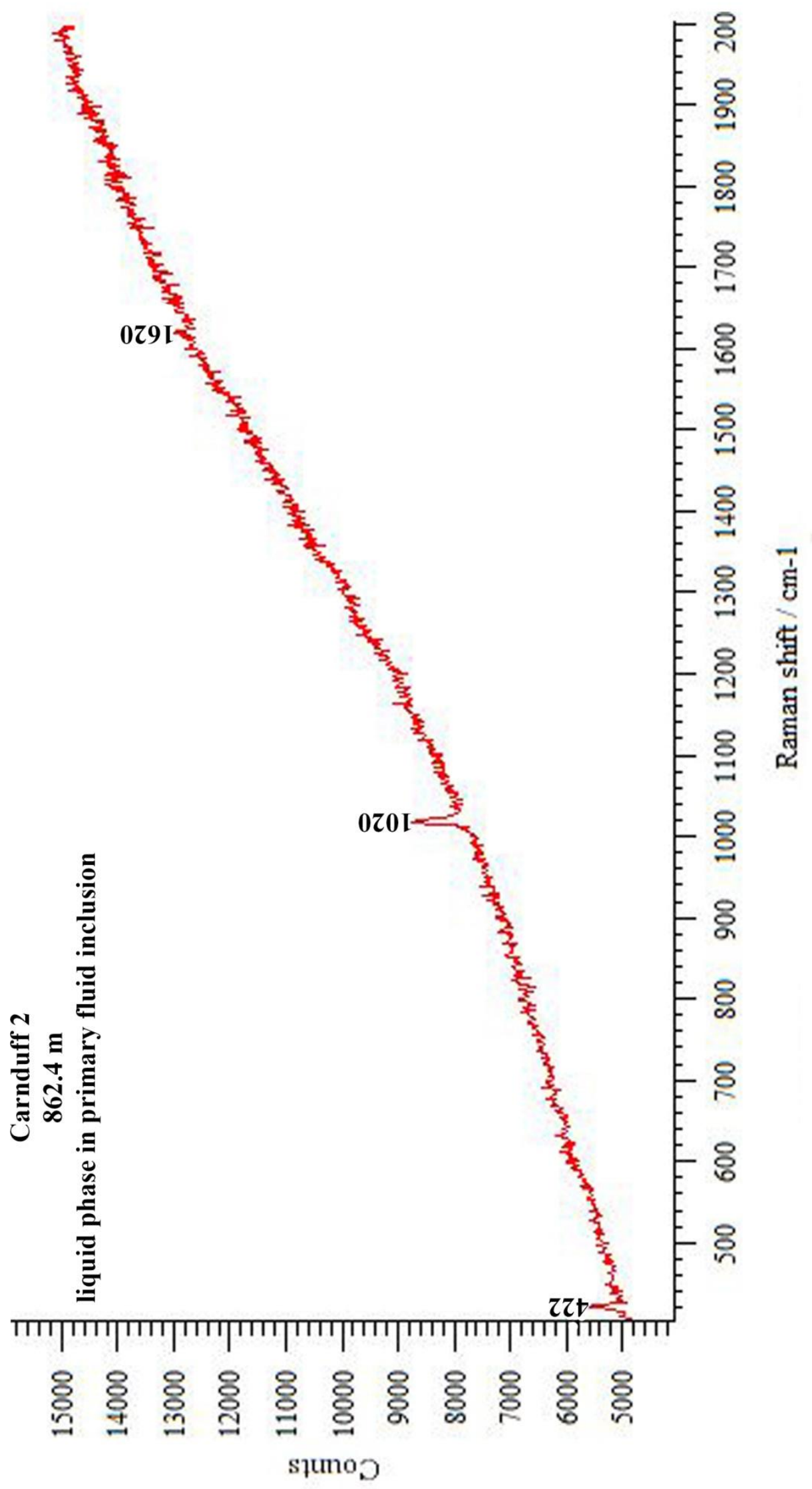


Eichenlaub, L.A., 2016

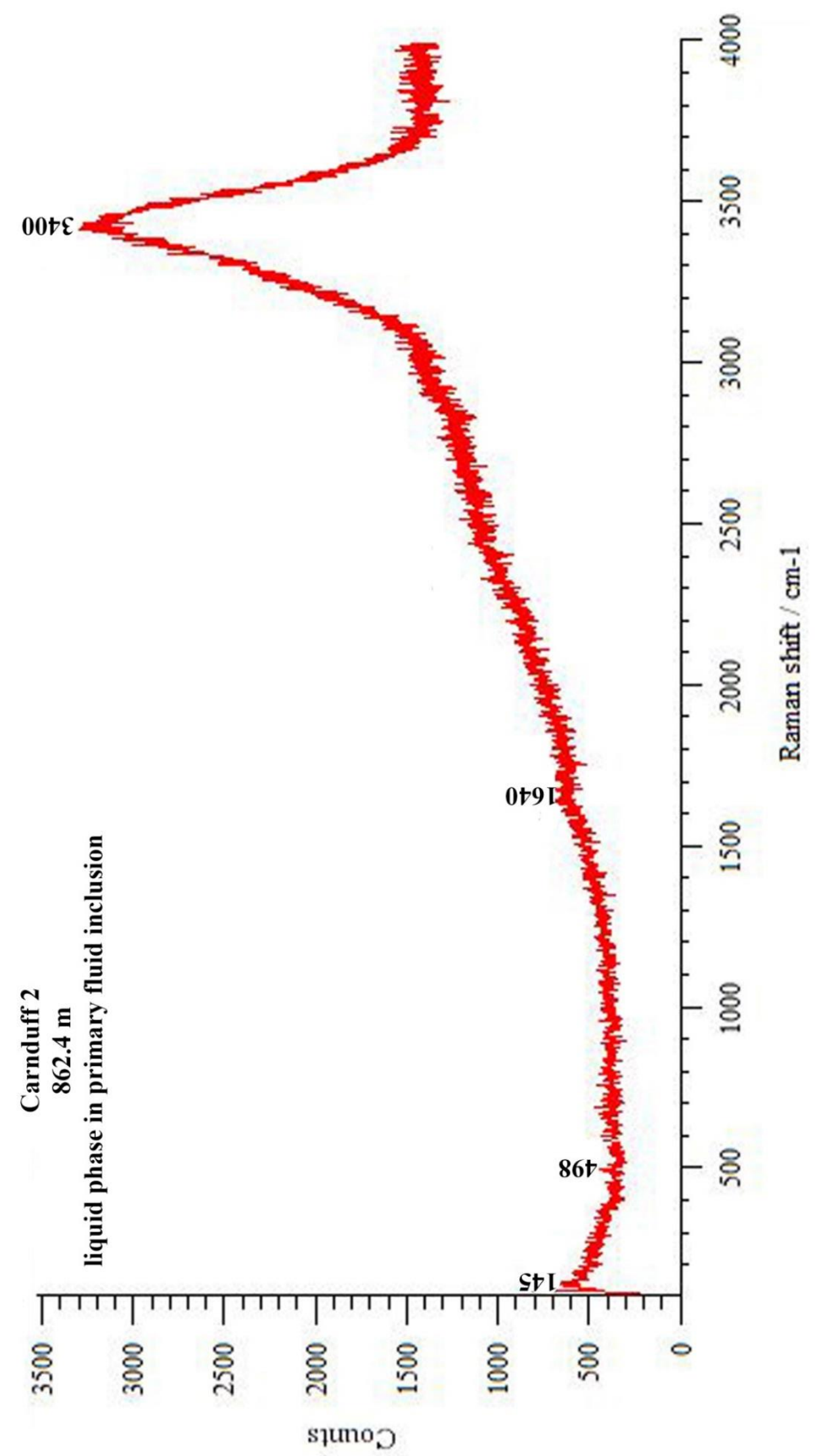


Eichenlaub, L.A., 2016



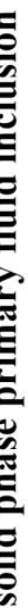

Eichenlaub, L.A., 2016

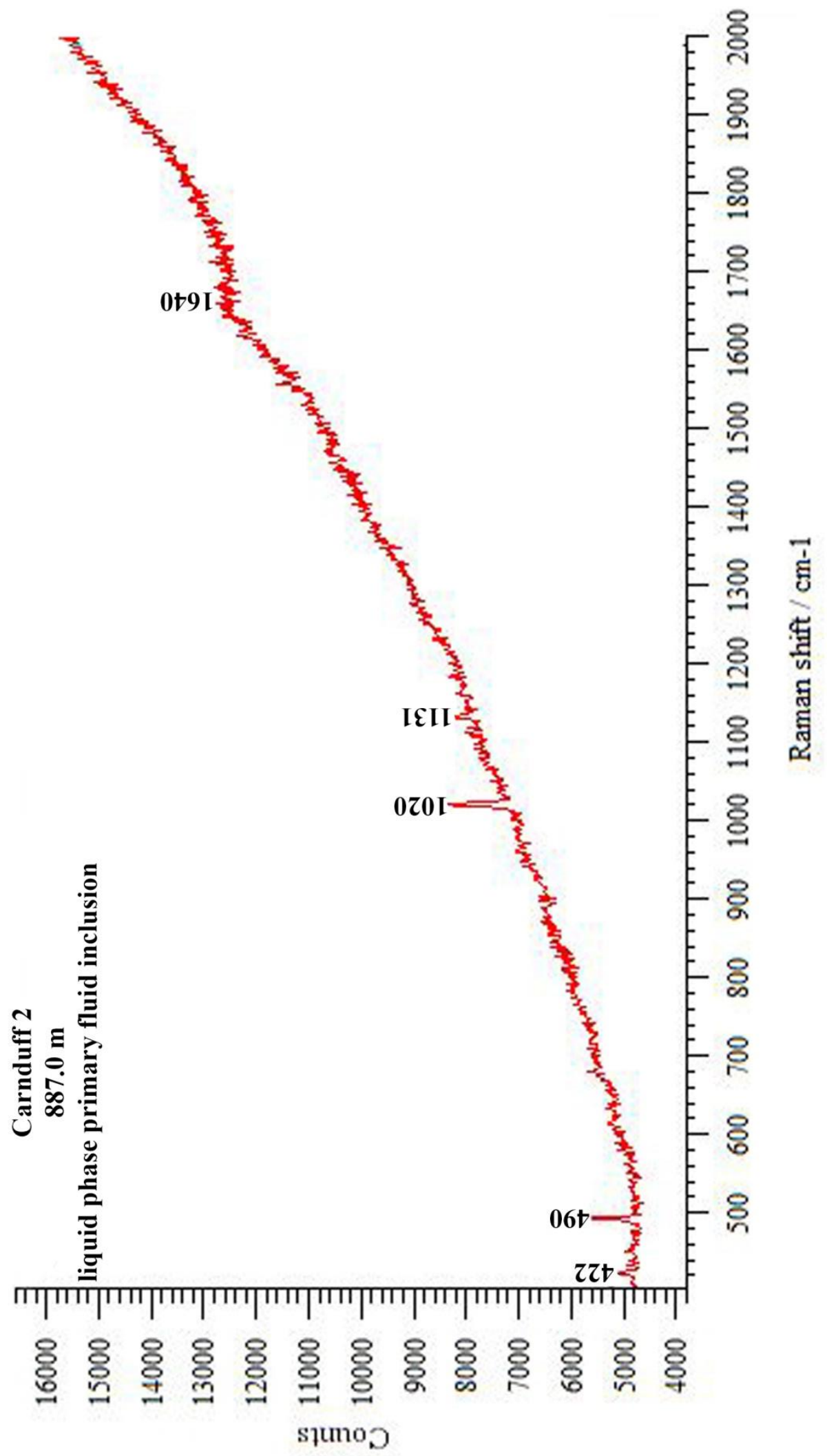


Eichenlaub, L.A., 2016

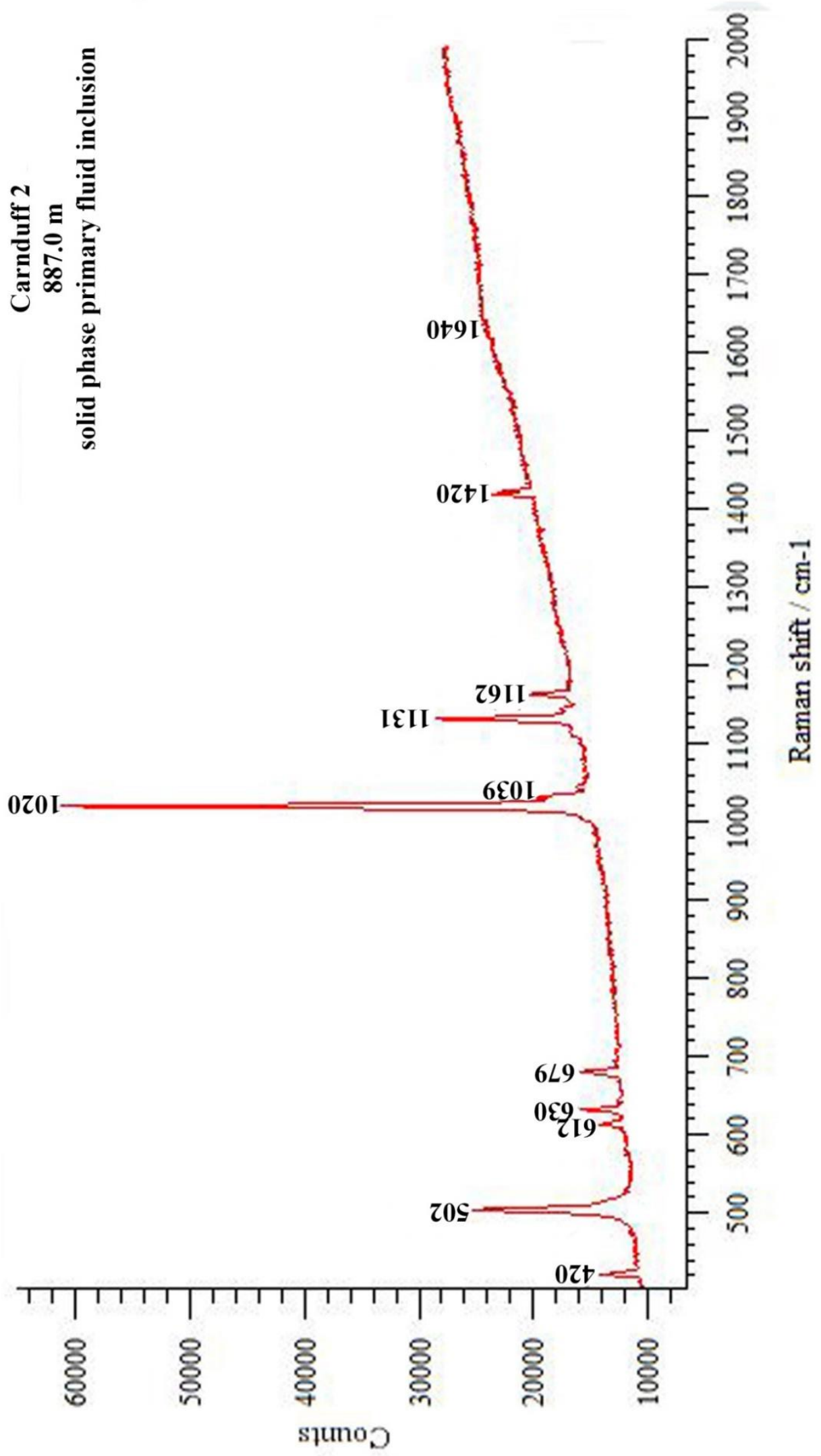


Eichenlaub, L.A., 2016




Eichenlaub, L.A., 2016




Eichenlaub, L.A., 2016

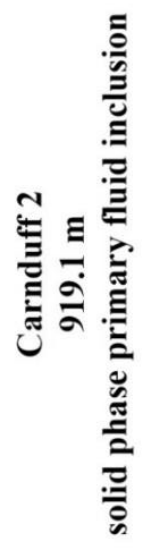



- 요

요

$\rightarrow$

- 8)

?

- 8

- 8

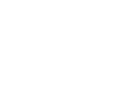

(II

SLII

- 8

8

- 8

- 8

$8\llcorner 9$

$I \tau_{t}+2 \varepsilon t=$

융 유 융

słumoว

용 
Eichenlaub, L.A., 2016




Eichenlaub, L.A., 2016

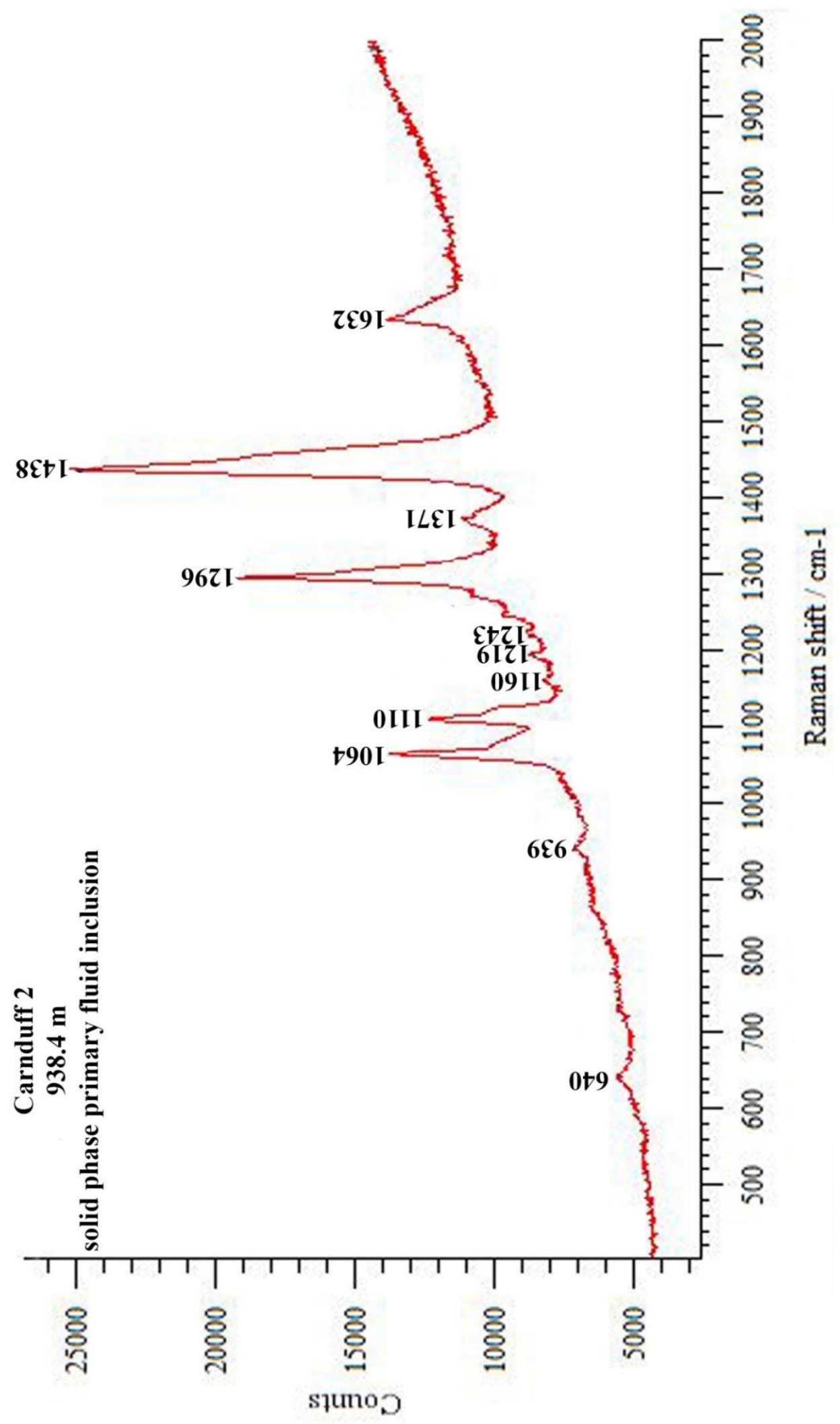

